\title{
"ROL DE DOMINIOS DE APOLIPOPROTEÍNA A-I EN \\ LA INTERACCIÓN DE LIPOPROTEÍNAS DE ALTA DENSIDAD \\ CON MEMBRANAS"
}

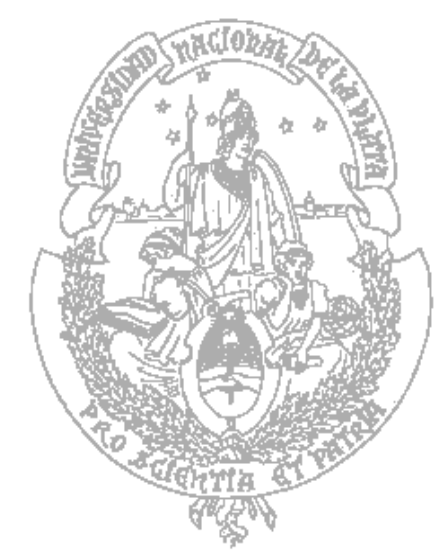

Tesis Doctoral

Universidad Nacional de La Plata

Facultad de Ciencias Exactas

Departamento de Ciencias

Biológicas

2008

Tesista: Eduardo Daniel Prieto

Director: Dr. Horacio Alberto Garda

Co-Director: Dra María Alejandra Tricerri

Asesora Científica: Dra. Laura S. Bakas 
Hota 1238.

2008 , Se

- E F.C.

can, Lelia

- el trabajo.

tentisi fizede

o'n aluove,

no selli, bojo

i al

Exactas

serteds for

¿ imprtants

hit con

chos

$2 \operatorname{los}$

N. Para la

fran

nopicas

for

ción - la

ie investiys.

La cijuriós

nte enel

mobar el

Sosertelis, 4

tolez
Eu el dia de la fecha se reune la conusion asesora designada yara evaluar el trabajo de tesir dictoral del Brobco. Eduando Daniel Preeto, títulodo "Rol de dominior de apolipoprotema A-1 u la interacuón de eipoprotentas de alta deusidod on menhanas" jue realizara bajo La dreccing del De. Horacio Hebuto Garda i la codrección de la Dra. Marea ste jaudra Iricesii, contardo in el asesorament cuentifeco de la Dia. Laura S. Babas, propesora de exta casa, cm el propósito de optar al grodo de Joctor de la Facuetad de Cuncior Exactor. de la UNLP.

La redacerń del trabajo fue dara grdenada. 'Ta uitroducen hoce reperencia a los caracterúticas de los aprolifroteinas $\mathrm{g}$ ou re de trousporte de los lisidos,

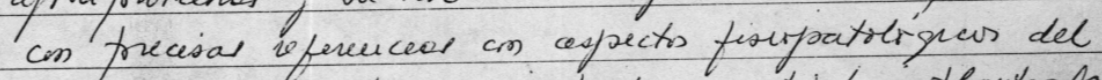
prouso. Ia hepótesir del trabojo cita bue flanteoda 3 los objetim del musm on perteneester conduceulé im el propósets de evaluar el we de ceitos domenios de $C_{C}$ aprepprterna A-I (Apo A-I) en la iuteracury de lipoprituna de alta deusidod cm meutranos. Ta parte expeumental está cuidadoramente descupta o clbarca una multiflicidod de enetralologías. Los resuetads troer sedo erpuestós in grau preciseon. La descusion' ha sedo realizoda en forma menuciosa if los conclesines fuales on aridos, efectelando bu valuoss aporte al cmorinnento de la interacición de lia spo A-I con distuitos autornos

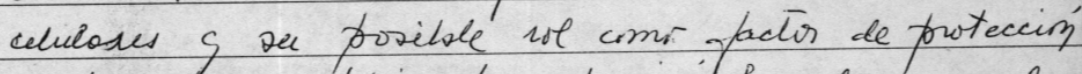
auti-ateros derótico. La exposicin fue dara 7 el doctoraudo en icleució conver profenidameute el 
tema. Por todo lo experests recimendamos la apolsacioń dee preseute trabajo de tesis dactoral tugumor sea calificador Com Sobresalieiti 10 (diez). -

La Pceta, Septumbre 26 de 2008.-

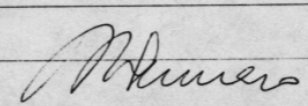

Dra. Aua Maria Gernaw

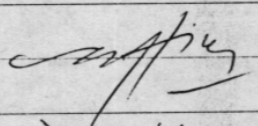

DR. Néstor O. Caffini

$$
\text { montrunfuencf? }
$$

Dr. Carlos stkerto Marra

Los onieubros del furado depar constancia que el trabajo queda bprobadr'y calificadr con diez zuntos (10 tuntos), Jobresa lieite.

Metruewo

Ana $\mu$ Genuars

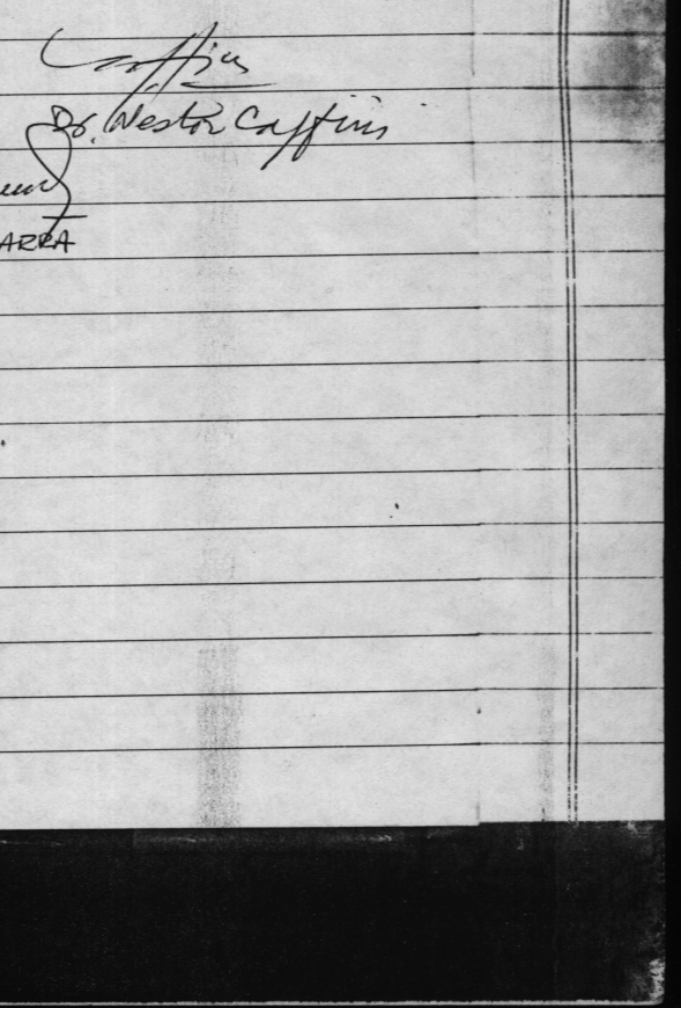

3 
El presente trabajo de tesis, para optar al grado de Doctor de la Facultad de Ciencias Exactas de la Universidad Nacional de La Plata, fue realizado en el Instituto de Investigaciones Bioquímicas de La Plata (INIBIOLP), Fac. de Cs. Médicas, UNLP, bajo la dirección del Dr. Horacio Alberto Garda y la co-dirección de la Dra. María Alejandra Tricerri. 
Mención

El presente trabajo de tesis fue realizado gracias al sostén económico en becas y subsidios de:

Ministerio de Salud de la Nación, Subsidio Ramón Carrillo Oñativia IUPAB

Comisión de Investigaciones Científicas de Buenos Aires (CIC BA) Consejo Nacional de Investigaciones Científicas y Técnicas (CONICET) Secretaría de Ciencia y Tecnología (SECyT) 
Dedico este trabajo a:

Mi PAPA, Julián Alberto Prieto, A quien la muerte enamorada no le permitió ver ni disfrutar los logros de sus hijos.

A mi Mamá, Nélida Ana Kaseta, por su apoyo incondicional.

A Esperanza que es el amor de mi vida. 
Como diría Larralde “...el paso del buey es lento, pero su fuerza es pareja...", es la frase que simplifica este trabajo de tesis, ya que en estos años en los que me he dedicado a incursionar en la investigación, he aprendido no solamente conceptos científicos sino también humanos, y en los cuales aprendí principalmente a convivir con un grupo de personas, con todo lo que ello implica....

Quisiera agradecer primero a los directores del INIBIOLP en el transcurso del trabajo, al Dr. Brenner y la Dra. María Josefa Tacconi de Alaniz (FITA) que me permitieron realizar mi labor en este instituto.

Luego querría agradecer a los que trabajaron conmigo en el Altillo, Mauro, Nicolás, Magali, Claudia, Jole, Paula y Omar, por las largas horas de trabajo, charlas y charlas en tonos altos (casi gritos), ya que si bien no es un club social, hicieron que uno disfrute las horas de trabajo. A integrantes del instituto con los cuales compartí, y espero seguir haciéndolo, muy lindos momentos, como ser Piky, Mabel, integrantes de los laboratorios 12, 8 bis, y a los becarios nuevos que ingresaron en el último tiempo.

Al grupo de pesca, que además de ir a pescar, compartimos unos cuantos litros de vino y charla de toda índole... y a veces... pescamos algo.

A los integrantes del laboratorio 7 y 7 bis con los que compartí todo este trayecto de mi vida, quienes han cubierto diferentes aspecto de mi persona... como ser contención, enojo, discusiones, mimadas y principalmente incondicionalidad. Ellos son: Vanesa, por compartir su escritorio y todo tipo de ayuda recíproca que nos hemos dado; Ale, por aceptar ser mi codirectora, aguantarme y siempre tratarme como a un par; Laurita, por su ayuda en todo lo que respecta a purificaciones de proteínas y por poder contar siempre con ella; y Ana, por las largas charlas, su amistad y 
por darme siempre una opinión desde el otro lado. A Laura Bakas por su asesoría científica y por ser una "compañera” de trabajo. A Florencia, Ángela, Sabina y Marina, porque si. A Juan por su ayuda y colaboración en muchos experimentos presentados en esta tesis.

Principalmente quiero dar las gracias a Horacio Garda, con quien siempre estaré en deuda ya que, extrañamente, confió en mí para realizar este trabajo.

Quisiera agradecer a la Facultad de Cs. Exactas por la educación que me brindó y a sus autoridades, que desde sus diferentes ámbitos de discusión siempre me inculcaron que la educación pública debe existir por y para el pueblo, y me invitaron a pelear por ella.

A mis amigos de la secundaría Tito y Martín, que siempre estuvieron atentos a mí, y a mis amigos de la facultad, Roy, el Enano, Laza, Leslie, Irene, Andrés, Trovato, el flaco, Tonga, Vivi, y algún otro que seguramente me estoy olvidando, que siempre están. A los amigos y compañeros de la denominada "Secta de los Sábados", comisiones 7 y 8 de Introducción y Qca. General.

Quisiera tener la oportunidad de agradecerle a Mauricio y a Yanina por ser mis amigos, ellos son el claro ejemplo de que si uno pudiera elegir sus parientes... a ellos lo elegiría como hermanos.

Quiero agradecerle a Esperanza por permitirme entrar en su vida, y hacer que me anime a tomar decisiones que de otra forma no hubiese tomado.

Por último quiero agradecer a mi familia, mi vieja, mis hermanos: Julián, Guillermo y Ana (mi melliza), mi prima Norma junto a su familia, ya que sin el apoyo y el esfuerzo de todo ellos, no hubiera logrado nada de lo que logré. Y agradecerles por creer y confiar siempre en mí. 
Espero no defraudarlos......

Bioq. Eduardo Daniel Prieto 


\section{INDICE}




\section{CAPÍTULO I: INTRODUCCIÓN}

- Introducción

Pág. 15

- El rol del transporte de lípidos

y su implicancia en enfermedades cardiovasculares

Pág. 21

- Transporte reverso de colesterol

Pág. 22

- Distintas conformaciones de las HDL

$$
\begin{aligned}
& \text { HDL- esféricas } \\
& \text { Pre- } \beta \text {-1 HDL } \\
& \text { Pre- } \beta \text {-2- HDL Discoidales }
\end{aligned}
$$

Pág. 25

Pág. 26

Pág. 27

Pág. 28

- Aspectos fisiopatológicos en el transporte de colesterol

Pág. 31

- Proteína mayoritaria en las HDL: Apolipoproteína A-I

- Interacción de apoA-I y de complejos

lipoproteicos de apoA-I con membranas lipídicas.

Pág. 35

- Conformación de la apoA-I en complejos discoidales

Pág. 39

- La región central de la apoA-I

Pág. 43

\section{CAPÍTULO II:}

- Hipótesis central y objetivos generales del trabajo

Pág. 46

\section{CAPÍTULO III: MATERIALES Y MÉTODOS}

- 1- Obtención de distintas formas de Apo A-I

- 1.1- Purificación de apoA-I de plasma

Pág. 50

- 1.2- Obtención de péptido central de apoA-I

Pág. 51

- 1.3- Obtención de apoA-I con secuencia nativa (Wild type) ó mutada mediante expresión a partir de cultivos bacterianos. 
Técnicas de biología molecular

Pág. 52

Tratamiento de bacterias para hacerlas competentes

Pág. 54

Transformación

Pág. 54

Construcción de los mutantes de apoA-I

Pág. 55

Expresión y purificación

Pág. 58

Eliminación de la secuencia de fusión mediante corte con

enzima proteolítica

Pág. 59

- 2-Técnicas electroforéticas

- 2.1- Geles de agarosa

Pág. 60

- 2.2- Geles de poliacrilamida

Pág. 61

- 3-Determinación de concentración de proteína

Pág. 63

- 4- Técnicas espectroscópicas

- 4.1-Resonancia Electrónica Paramagnética (EPR)

Pág. 64

- Efecto de movilidad en los espectros de EPR

Pág. 68

- Marcadores de spin

Pág. 70

- Parámetro de orden

Pág. 72

- Método experimental utilizado

Pág. 73

- 4.2-Fluorescencia

Pág. 74

- Anisotropía de fluorescencia

Pág. 79

- Transferencia de energía

Pág. 80

- Quenching o apagado de fluorescencia

Pág. 81

\section{CAPÍTULO IV: RESULTADOS}

- Parte A

- Rol e independencia funcional de las hélices Y centrales de apo A-I en la interacción con membranas.

Estudios con un péptido sintético

Pág. 85

- Afinidad de A-I 77-120 por membranas fosfolipídicas.

Pág. 85 
- Marcación por reactivos fotoactivables

- Cambios estructurales de AI 77-120 en la interacción con membranas: estudios de estructura secundaria por dicroísmo circular

Pág. 89

- Estudios de estructura oligomérica usando agentes entrecruzantes (crosslinkers)

Pág. 91

- Capacidad de AI 77-120 para formar complejos lipoproteicos

Pág. 93

- Independencia funcional de AI 77-120. Catálisis de la transferencia de colesterol o su análogo dehidroergosterol entre vesículas fosfolipídicas

Pag. 95

- Transferencia de dehidroergosterol entre vesículas

Pág. 95

- Transferencia de 3H-colesterol desde vesículas de carga negativa a vesículas neutras Pág. 96

- Conclusiones parciales Pág. 99

- Parte B

- Estudios de Resonancia de Electrónica Paramagnética

Pág. 102

- Influencia de la unión de apoA-I y AI 77-120 a vesículas fosfolipídicas sobre la movilidad de los lípidos de la membrana

Pág. 102

- Mediciones del ordenamiento de los lípidos en complejos lipoproteicos de apoA-I con DMPC generados por la micelización de vesículas en la transición de fase

Pág. 105

\section{- Parte C}

- Estudios con mutantes de apoA-I con un único residuo de triptofano (Trp)

Pág. 110

- Mutagénesis sitio-dirigida para la obtención de las mutantes de apoA-I de Trp único

Pág. 110

- Expresión, purificación y clivaje de las proteínas de fusión de los mutantes anteriores

- Expresión y purificación

- Corte con enzima proteolítica

1- Caracterización de las mutantes obtenidas 
1.b) Capacidad de las proteínas mutantes con único Trp para microsolubilizar vesículas de DMPC y generar complejos lipoproteicos

Pág.116

2- Estudios por espectroscopía de fluorescencia

2.a) Estudios de fluorescencia en el estado librede lípidos.

Evidencias de que las hélices Y centrales participan en la oligomerización de apoA-I

Pág.118

Apéndice I

Pág.126

2.b) Conformación de la región central de apoA-I en el estado unido a membranas

Pág. 127

2.c) Topología de inserción en la membrana de las hélices Y centrales. Mediciones de extinciónde la fluorescencia de Trp por extinguidores (quenchers) paramagnéticos localizados a diferente profundidad en la bicapa lipídica

Pág. 128

2.d) Configuración de apoA-I en complejos lipoproteicos discoidales. Evidencias de que la configuración es dependiente del método de reconstitución

Pág. 138

\section{CAPÍTULO V: DISCUSIÓN}

1. Obtención y caracterización de las mutantes

Pág. 147

2. Conformación de la región central en la proteína libre de lípidos (lipid-free)

Pág. 149

3. Interacción de la lipid-free con membranas

Pág. 151

a) Análisis estructural

Pág.151

b) Análisis funcional de la región central

Pág. 156

4. Partículas discoidales de HDL

Pág. 157

5. Conclusión General

Pág. 162

REFERENCIAS

Pág.164 
CAPÍTULO I:

INTRODUCCIÓN 


\section{Introducción}

La importancia de los lípidos para el funcionamiento celular es altamente reconocida. Los animales han desarrollado diferentes sistemas para la captación y remoción de lípidos de las células, y el transporte entre ellas. Estos sistemas incorporan de cientos a miles de moléculas de diferentes lípidos, como ser fosfolípidos, colesterol, ácidos grasos y triglicéridos, estabilizadas en el medio acuoso por moléculas proteicas, denominadas en conjunto Lipoproteínas. A los componentes proteicos libre de lípidos de éstas últimas se los denomina apolipoproteínas.

Las lipoproteínas de los mamíferos, y principalmente del humano, pertenecen a cuatro clases principales, clasificándose por su densidad, HDL, LDL, VLDL (de las siglas en ingles High Density Lipoprotein, Low Density Lipoprotein, y Very Low Density Lipoprotein, respectivamente); cuanto mayor relación proteínas/lípidos, mayor es su densidad. La cuarta clase de lipoproteínas son los denominados Quilomicrones (Qn, son los Quilomicrones nacientes; Qr, los remanentes), provenientes de la dieta, en donde la cantidad de lípidos es la mayor. La Fig I-1 muestra el perfil de migración de las mismas obtenido dependiendo el método

\begin{tabular}{|c|c|c|c|}
\hline Apolipoproteína & Peso molecular (en kD) & $\begin{array}{c}\text { Concentración en } \\
\text { plasma (gr/L) }\end{array}$ & Distribución \\
\hline AI & 28 & $1,0-1,4$ & HDL, Qn \\
\hline AII & 17 & $0,3-0,5$ & HDL, Qn \\
\hline AIV & 46 & $0,5-0,16$ & HDL, Qn \\
\hline (a) & $300-800$ & $0,01-0,50$ & Lp(a) \\
\hline B100 & 512 & $0,7-1,0$ & $\begin{array}{c}\text { VLDL, IDL, LDL, } \\
\text { Lp(a) }\end{array}$ \\
\hline B48 & 242 & $0,03-0,05$ & Qn, Qr \\
\hline CI & 7 & $0,04-0,06$ & $\begin{array}{c}\text { Qn, VLDL, IDL, } \\
\text { HDL }\end{array}$ \\
\hline CII & 9 & $0,03-0,05$ & $\begin{array}{c}\text { Qn, VLDL, IDL, } \\
\text { HDL }\end{array}$ \\
\hline CIII & 9 & $0,12-0,14$ & $\begin{array}{c}\text { Qn, VLDL, IDL, } \\
\text { HDL }\end{array}$ \\
\hline D (AIII) & 19 & $0,06-0,07$ & HDL \\
\hline E & 34 & $0,03-0,05$ & Qn, VLDL, HDL \\
\hline
\end{tabular}

Tabla I-1: resumen de las características de las apolipoproteínas humanas. 


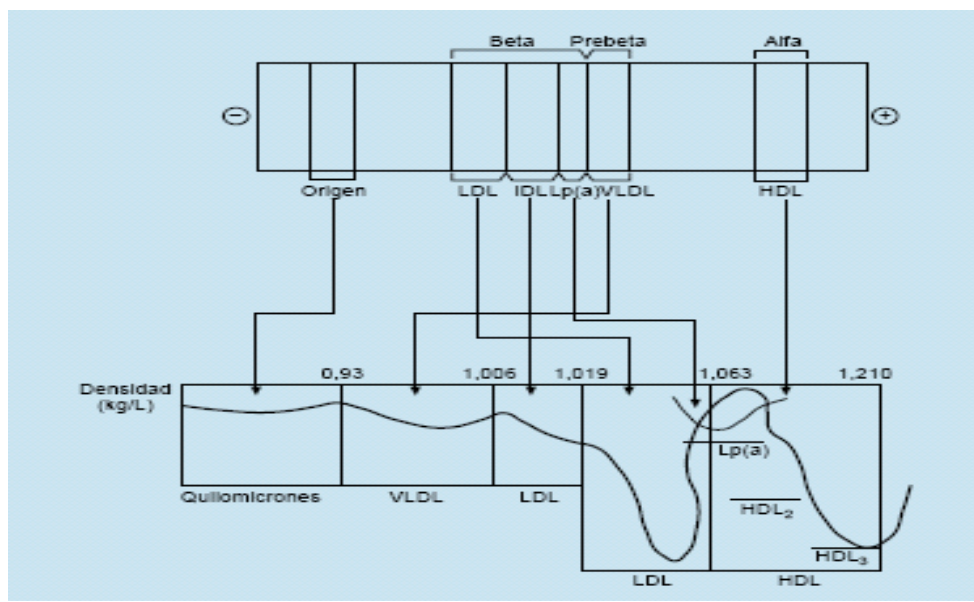

Fig. I-1: Arriba se muestra la movilidad de las lipoproteínas cuando se les aplica un campo eléctrico. Abajo: movilidad de las mismas en un gradiente de densidad.

Cada clase de lipoproteína tiene una composición lipídica, proteica y función diferente, inclusive dentro de cada clase pueden considerarse más de una población. Las diferentes apolipoproteínas confieren estructura a las partículas, promueven la interacción con enzimas y proteínas extracelulares, como así también promueven la interacción con membranas por medio de receptores. En la Tabla I-1 se resumen las características principales y las lipoproteínas en las que se encuentran.

La mayor parte de los lípidos ingeridos en la dieta, luego de ser emulsionados por las sales biliares son hidrolizados en la luz intestinal por la lipasa pancreática; los ácidos grasos de menos de 12 átomos de carbono pasan directamente a la circulación porta y son transportados unidos a albúmina por fuera de este sistema. Los ácidos grasos de mayor longitud en cambio se reesterifican uniéndose a grupos alcohólicos del glicerol ó también al colesterol, siendo rápidamente re-esterificados gracias a la acción de la enzima acilcoenzima A-colesterol-aciltransferasa (ACAT). Estos lípidos son transportados como partículas lipoproteicas denominadas Quilomicrones, y poseen las proteínas apoB48 principalmente, cantidades menores de apoA-I, apoA-II y apoA-IV, y trazas de apo CII, siendo secretadas a la linfa y luego transportadas al torrente sanguíneo; en circulación los Quilomicrones son remodelados por medio de la lipoproteinlipasa de los vasos sanguíneos, la cual hidroliza los triglicéridos, dando origen a pequeños Quilomicrones residuales, ricos en colesterol, los que son incorporados a las células hepáticas por medio de receptores. En la Fig. I-2 se muestra un esquema general de este proceso. 


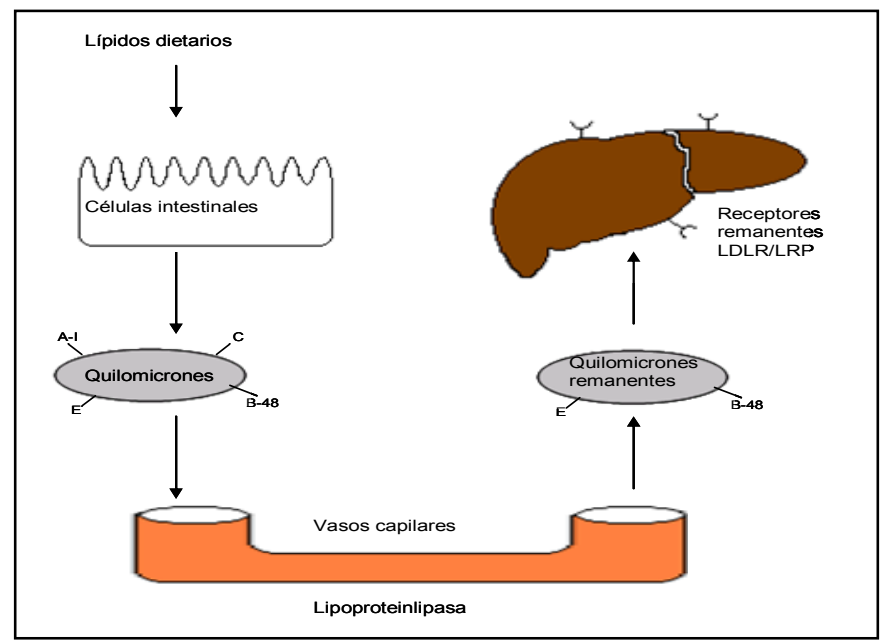

Fig. I-2: Se muestra la ruta metabólica de los lípidos ingeridos en la dieta

Las VLDL se originan a partir de los lípidos hepáticos sintetizados de novo ó recaptados a partir de otras lipoproteínas en circulación. Estas lipoproteínas también son metabolizadas por la acción lipoproteinlipasa, y al ir perdiendo lípidos (triglicéridos) se van transformando en partículas de mayor densidad, transformándose en IDL (Intermedial Density Lipoprotein), que al seguir su catabolismo son transformadas en LDL. Tanto las IDL como las LDL pueden ser eliminadas de la circulación mediante endocitosis mediada por receptores, que reconocen a las apoB100 y apoE. En el caso de las IDL, el reconocimiento de los receptores es mediado por la apoE, mientras que en la LDL es por medio de las apoB100 (Lodish et al., 2005) (ver esquema a continuación Fig. I-3).

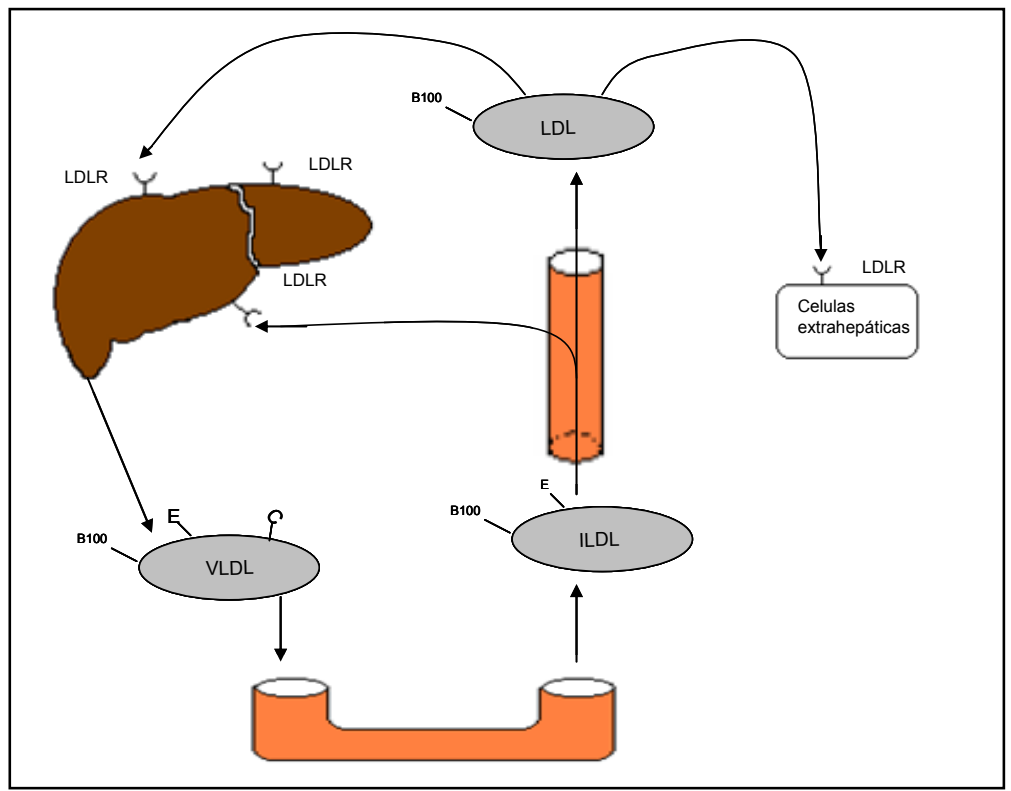

Fig. I-3: Metabolismo de VLDL 
El metabolismo de estas partículas es de gran importancia, ya que trasportan la mayor cantidad de colesterol plasmático hacia los tejidos periféricos, asociando su exceso con características aterogénicas.

Las células poseen receptores para las LDL e IDL, y la cantidad de colesterol celular modula negativamente la biosíntesis de colesterol de novo como así también la síntesis de receptores de membranas (Brown and Goldstein, 1986). Una vez unidas a su receptor, las partículas lipoproteicas son incorporadas a las células por endocitosis y la vesícula formada se fusiona a los lisosomas, cuyas enzimas degradan los distintos componentes de las partículas de LDL.

Los macrófagos poseen además receptores que reconocen LDL modificadas, a fin de eliminar del torrente sanguíneo lipoproteínas que sufren oxidaciones ó metilaciones. Existen en los macrófagos dos tipo de estos receptores, los que reconocen LDL acetiladas u oxidadas y las que reconocen las LDL oxidadas únicamente; ninguno de estos receptores es inhibido en su síntesis por el colesterol intracelular en su captación de colesterol y por lo tanto la sobre acumulación de esteroles transforma a estas células en las llamadas células espumosas, características de las lesiones ateromatosas (Brown and Goldstein, 1983)

Existe una segunda forma de incorporar colesterol desde las partículas en las células hepáticas y esteroidogénicas, principal lugar en donde se metabolizan las HDL, mediante la unión de las lipoproteínas a receptores de membrana llamados SR-BI (de scavenger receptor, clase B tipo I) y la incorporación se cree que es por una hemifusión de la partícula con la membrana plasmática, que resulta en una incorporación de los ésteres de colesterol a la membrana, transfiriéndose al lado citosólico desde donde son hidrolizadas por esterazas citoplasmáticas no lisosómicas (Lodish et al., 2005). Las partículas remanentes se disocian de su receptor y regresan a circulación, entrando en contacto nuevamente con membranas ú otras lipoproteínas.

Estos receptores difieren fundamentalmente de los receptores de LDL en dos aspectos, el primero en que se encuentran agrupados sobre microvellocidades y sobre "dominios balsa" de la superficie celular denominados "raft" y no en fosa de clatrina como en el caso de los receptores de LDL, y segundo, el SR-BI media la transferencia de lípidos a través de membrana y no por endocitosis (Lodish et al., 2005), (Martinez et al., 2004)

Los niveles de colesterol celular ejercen una serie de autorregulaciones para su homeostasis, como inhibir la Hidroxi metil glutaril-CoA -reductasa (HMG-CoA- 
reductasa), que es la enzima limitante en la síntesis de colesterol, además de la inhibición en la síntesis de los receptores de LDL, y la activación de la enzima ACAT que esterifica intracelularmente el colesterol libre para su almacenamiento.

Las diferentes demandas de lípidos requeridos por los diferentes tejidos hace que la regulación compleja del metabolismo de ácidos grasos y demás lípidos, características de los mamíferos, se deba a una cantidad de factores de transcripción, como ser los SREBP (de las siglas en inglés de Sterol Regulatory Elements Binding Protein) (Lodish et al., 2005) que controlan la transcripción de proteínas de síntesis y degradación como así de las de transporte y almacenamiento de los mismos, los cuales no serán discutidos en este trabajo, aunque, a fin de graficar estos procesos, se muestra un esquema en la Fig. I-4.

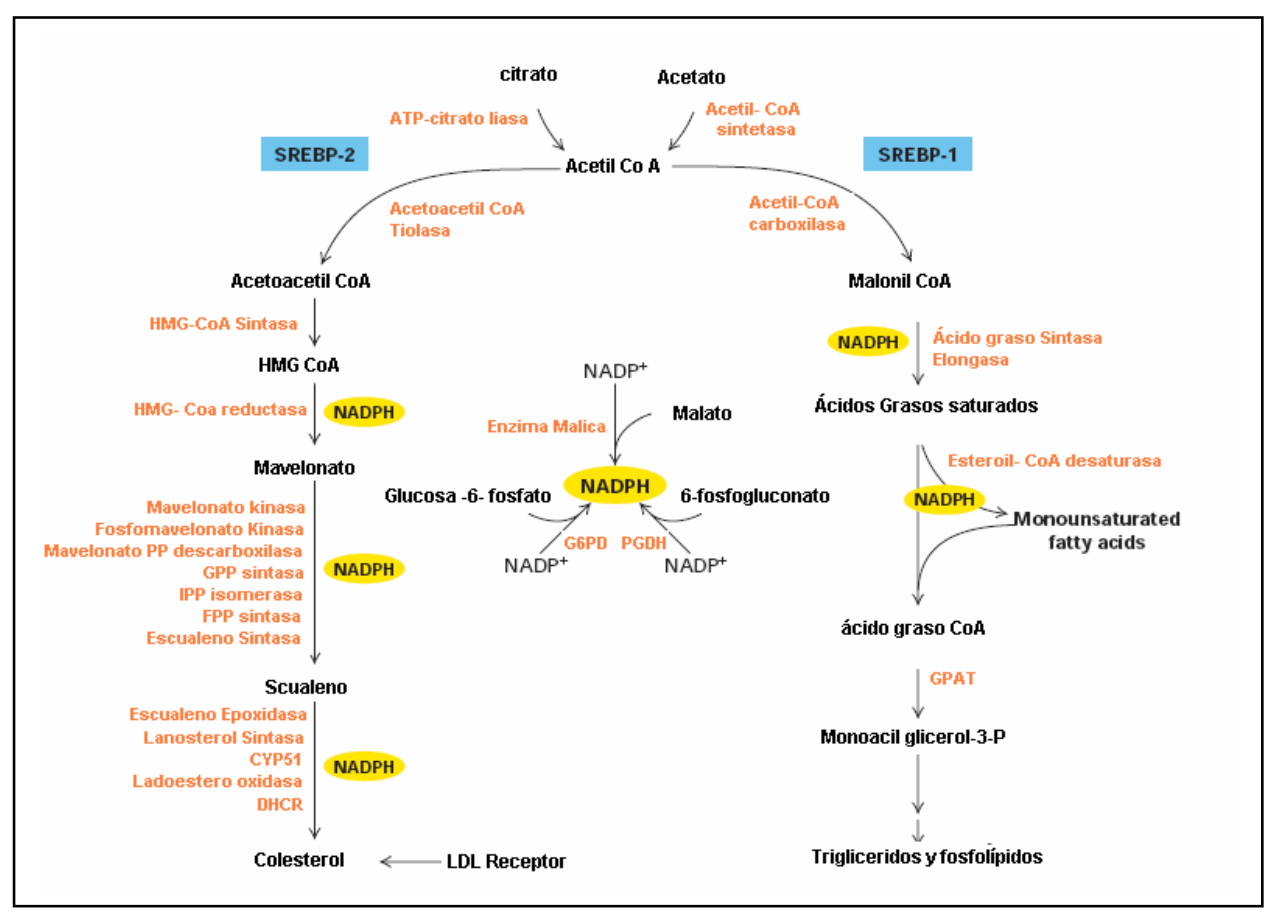

Fig. I-4: se muestra las vías de síntesis de colesterol como de triglicéridos y fosfolípidos, junto con dos factores de regulación (Lodish et al., 2005) 


\section{EI rol del transporte de lípidos y su implicancia en enfermedades cardiovasculares}

Está aceptado y avalado por estudios epidemiológicos la correlación inversa que existe entre los niveles de HDL en plasma y el riesgo de enfermedades cardiovasculares, en concordancia con el concepto que las HDL protegen contra la aterogénesis (Stampfer et al., 1991). Se demostró que la administración por vía venosa de HDL a ratas con dietas elevada en colesterol (Badimon et al., 1989) inhibe el desarrollo de depósitos lipídicos en la pared aórtica. También se reportó que la administración de HDL después del desarrollo de las lesiones ateroescleróticas indujo a la regresión de las lesiones preexistentes (Yokoyama, 2006). Muchos estudios en modelos animales mostraron también que el descenso de los niveles plasmáticos de HDL, viene acompañado de una lenta remoción de los depósitos lipídicos intra y extracelulares (Small, 1988), pero se observa en algunos casos, que la deficiencia plasmática de los niveles de HDL no está asociada a enfermedades cardiovasculares, lo que implica que una alteración en el transporte de colesterol mediada por las HDL predispone a un individuo a aterogénesis prematura (Assmann et al., 1993).

Esto último puede ser explicado por el hecho que la remoción de lípidos celulares por lipoproteínas protege de lesiones cardiovasculares solamente cuando éstas son ocasionadas y propagadas por otros factores, como ser los que reclutan monocitos en las paredes arteriales e induzcan a la maduración de macrófagos, promoviendo los depósitos de colesterol en éstas y otras células. La acumulación de lipoproteínas ricas en colesterol como las LDL es importante en la formación de las lesiones ateromatosas, ya que estas partículas inducen la liberación de señales inflamatorias reclutando monocitos y son fuente para que el exceso de colesterol sea captado por macrófagos (Williams and Tabas, 1995). Las HDL inhiben la adhesión de macrófagos al endotelio, pudiendo explicar de esta forma porqué pacientes con deficiencia en HDL sufren depósitos masivos de esteroles en macrófagos de varios tejidos, pero no sufren enfermedades cardiovasculares.

Una vez iniciada la lesión aterosclerótica hay factores que influyen en su progresión, entre ellos disponibilidad de las preß1-HDL y de la actividad del sistema celular de remover colesterol mediado por apolipoproteínas. 


\section{Transporte reverso de colesterol}

Las lipoproteínas HDL tienen una gran relevancia en el proceso denominado “Transporte Reverso de Colesterol" (TRC), en el cual el exceso de colesterol es transportado desde las células periféricas (tejido extra hepático) hacia el hígado ó tejidos esteroidogénicos para su catabolismo y eliminación. Este proceso es de gran importancia, ya que el tejido periférico no puede catabolizar el exceso de colesterol. Las HDL participan en varios eventos con implicancia fisiopatológica en la prevención de la aterogénesis (como la inhibición de la adhesión de macrófagos en endotelio ó mediante acción antioxidante (O'Connell and Genest, 2001), pero en particular su participación en el TRC se considera esencial (Lewis and Rader, 2005). El rol de las HDL en el transporte reverso está avalado por datos experimentales y epidemiológicos; entre ellos se observa que las HDL aclaran el contenido de colesterol de determinados cultivos celulares y además que bajo contenido de HDL está asociado a lesiones ateromatosas (Gordon, 1990), como así también que determinados defectos genéticos en el metabolismo de las HDL perturban el transporte reverso del colesterol (Joyce et al., 2003), (Oram and Lawn, 2001).

Hay que tener en cuenta que las HDL no son solamente aquellas que se encuentran en el plasma, ya que las células periféricas se encuentran rodeadas o bañadas de fluido intersticial, separado del plasma por tejido endotelial. Las partículas de HDL llegan a este espacio por filtración desde el plasma a través de este tejido y por excreción de apolipoproteínas desde algunas células periféricas, las que luego son remodeladas a partículas de mayor tamaño.

Las bases moleculares de la biogénesis, de las HDL no están bien entendidas. Las proteínas mayoritarias de las HDL son la apoA-I (un 70\% del total de proteínas) y apoA-II, las que son sintetizadas y secretadas por el hígado y células intestinales. Ya sea por interacción de apoA-I libre con membranas celulares, así como por liberación al medio de apo previamente lipidada, se forman partículas con bajo contenido de colesterol. La migración de estas partículas puede ser $\alpha$ ó $\beta$ dependiendo del tipo celular. La razón de la diferencia no es bien conocida, pero es postulado que las partículas formadas por activación del ABCA1, poseen preferentemente migración $\alpha$. Se postula que la migración diferencial se debe a la presencia de mayor proporción de lípidos con carga negativa en ese caso, que aumentan su movilidad (Krimbou et al., 2005).

Cuando estas partículas, ó la apoA-I libre de lípidos interaccionan con membranas desencadenan señales intracelulares que favorecen la exportación de colesterol. Entre otras 
reduce los pooles de colesterol disponibles para el enzima ACAT, y favorece el movimiento de colesterol hacia la membrana, como así también la activación de un miembro de proteínas transportadoras, las "ATP- binding Cassette" (ABCA1). Este transportador posee actividad flipasa (o sea intercambia fosfolípidos desde el lado interno al externo de la membrana), y así, al unir apoA-I (Wang et al., 2001), favorece que la proteína capte fosfolípidos negativos, generando, como se mencionó partículas de movilidad $\alpha$. (Fig I-5: se muestran dos posibles mecanismo de formación de HDL discoidales)

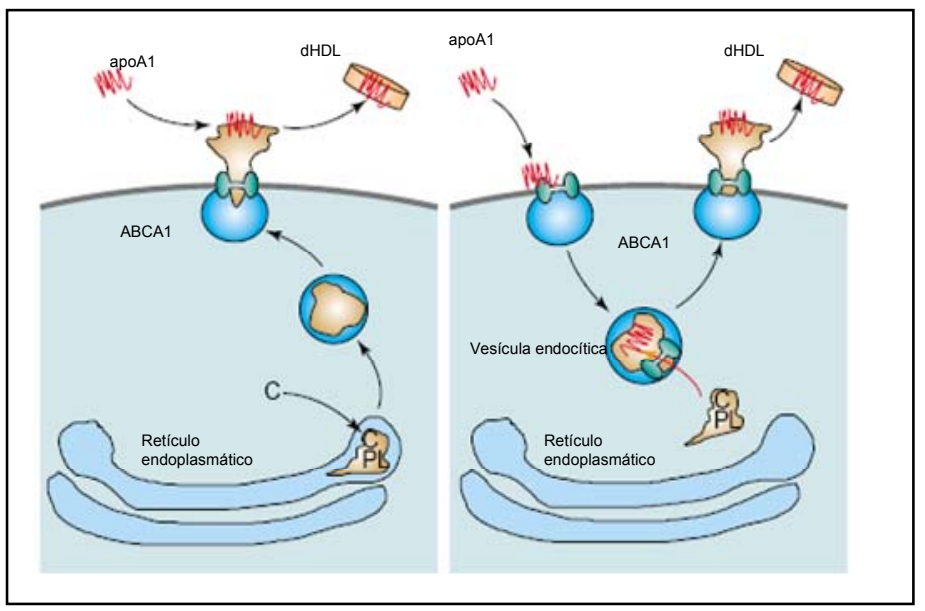

Fig. I-5: Dos posibles mecanismos que muestran como el ABCA1 "carga" a la apoA-I. a): el exceso de colesterol es unido a fosfolípidos en el aparato de golgi y posteriormente traslocado por ABCA1 y presentados a la apoA-I. b)apo A-I interacciona con ABCA1 y es endocitada, en vesículas intracelular, en donde se unen el exeseso de colesterol, posteriormente esta vesícula es vuelta a transportar a la superficie de la membrana

Las apoA-I pobres en lípidos son enriquecidas en colesterol en dominios de las membranas ricos en este lípido, denominados "caveolas", los cuales no poseen ABCA1.

Una vez enriquecidas de fosfolípidos y colesterol, estas HDLs tienen una conformación discoidal, y pasan del espacio intersticial al plasma en donde son sustrato de la LCAT (Jonas, 2000) que al esterificar colesterol generan un núcleo hidrofóbico de lípidos neutros (en pacientes con déficit enzimático de LCAT existe un aumento de partículas de movilidad pre- $\beta$ ). Por acción continua de esta enzima se va incorporando ésteres de colesterol, formando primero partículas esféricas densas denominadas HDL3, y luego HDL2 (mayoritarias) que incluso se pueden transformar en partículas esféricas más grandes denominándose HDL1. Las HDL2 transfieren ésteres de colesterol a otras lipoproteínas gracias a las proteínas transportadoras de ésteres de colesterol (PTEC), intercambiando triglicéridos desde las LDL o Quilomicrones. La lipasa hepática a su vez hidroliza estos ésteres y convierte las HDL2 en HDL3, siendo buenos aceptores de colesterol celular. La vida media de las HDL es estimada entre 3 y 6 días, pero el intercambio de proteínas y lípidos es de vida media más corta, siendo el proceso general 
muy dinámico, lo que asegura su alta eficiencia. Este hecho induce como consecuencia la morfología esférica de las $\alpha$-HDL mayoritarias en plasma. Finalmente en el hígado y tejidos esteroidogénicos, en procesos mediados por SR-B1 se captan selectivamente ésteres de colesterol y estas $\alpha$-HDL. Como resultado de este catabolismo, se vuelve a liberar a circulación apo pobre en lípidos, regenerándose el ciclo de las HDL. Este proceso es esquematizado en la figura I-6.(Fielding et al., 2000),(Fielding and Fielding, 2001), y un esquema general del TRC en la Figura I-6.

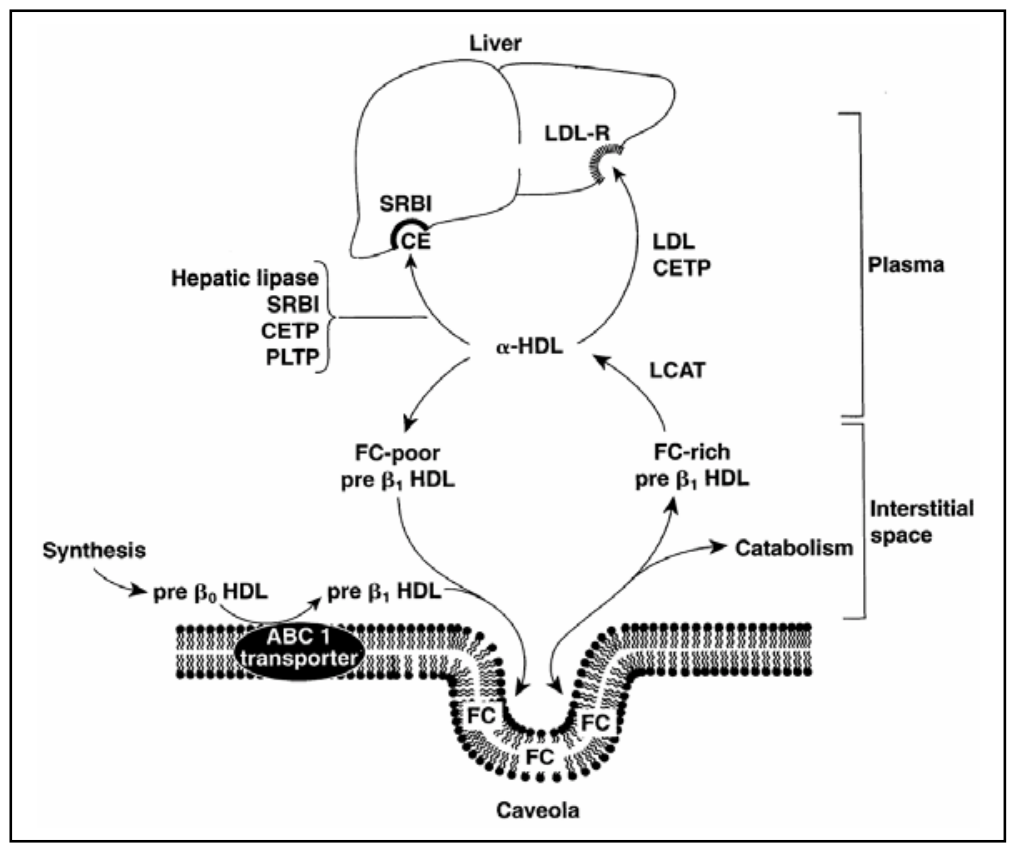

Fig. I-6: Modelo para la salida de fosfolípidos y colesterol de células. (Fielding et al., 2000), (Fielding et al., 2001) 


\section{Distintas conformaciones de las HDL}

Se mencionó previamente que las partículas lipoproteicas poseen diferentes conformaciones, inclusive en las mismas especies, que son fundamentales para realizar distintos aspectos fisiológicos. En las HDL estas conformaciones van desde pequeñas partículas discoidales hasta grandes y esféricas, y por lo tanto se requiere que la apoA-I sufra grandes cambios conformacionales a fin de adaptarse a los distintos entornos. De acuerdo al modo de separarlas, ya sea por electrofóresis o gradientes de densidad, existen diversas clasificaciones, (Anderson et al., 1977), (Barrans et al., 1996)

Básicamente existen tres tipos de estructuras de HDL en las que se encuentra la apoA-I: 1) grandes partículas esféricas constituidas tanto por lípidos neutros comos por lípidos polares, 2) partículas discoidales constituidas principalmente por lípidos polares y 3) partículas pequeñas pobres en lípidos. Si se realiza una separación electrofóretica bidimensional del plasma humano, la mayor parte de la apoA-I se encuentra asociada a partículas esféricas de movilidad electroforética $\alpha$ (9-12 $\mathrm{nm}$ de diámetro), y otra pequeña fracción a lipoproteínas de movilidad pre- $\beta$ (Castro and Fielding, 1988). Tanto en las $\alpha$ como en las pre- $\beta$, su densidad y tamaño son heterogéneos.

\section{$\underline{\text { HDL- esféricas }}$}

La mayor proporción de estas HDL contienen apoA-I y apo-AII, siendo esta última la segunda apolipoproteína más abundante en las HDL. La proporción de HDL esféricas que solamente contienen apoA-I (11-45\%) se denomina LpAI (Fielding and Fielding, 1981), pudiendo estabilizar un núcleo hidrofóbico de ésteres de colesterol (Scanu and Tardieu, 1971) gracias a la interacción entre los lípidos y las caras hidrofóbicas de las hélices de la apoA-I.

La conformación de esta proteína en estas partículas es muy diferente a la que posee cuando se encuentra formando complejos discoidales, los primeros indicios al respecto fueron realizados con anticuerpos monoclonales que identifican diferentes regiones o epitopes (Marcel et al., 1991), lo que indicaría grandes cambios conformacionales, y por lo tanto gran flexibilidad entre las diferentes regiones de la apoAI.

Estas partículas esféricas contienen igual masa de lípidos que de proteínas, (en promedio entre las HDL2 y HDL3) y se cree que la apoA-I formaría una monocapa externa rodeando a un núcleo hidrofóbico con la cara hidrofóbica de las hélices anfipáticas 
(ver mas abajo) expuesta hacia los lípidos del core hidrofóbico (el esquema se muestra en la figura.I-6). El colesterol libre puede particionarse entre el núcleo y la superficie, con una mayor fracción en esta última (Lund-Katz et al., 1982), la relación que existe en estas partículas de fosfolípidos/colesterol es de 5/1 (similar a la de las membranas). Todas estas relaciones son dinámicas en el sentido que tanto lípidos como proteínas se pueden intercambiar con otras lipoproteínas en el plasma.

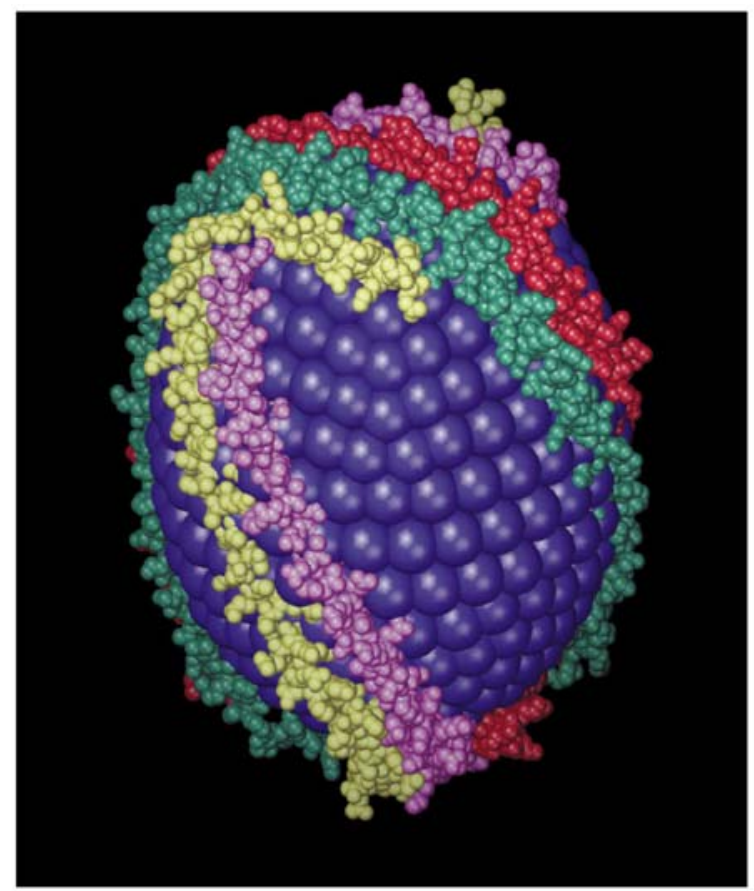

Fig. I-7 Se muestra en la misma el modelo de $\alpha$ HDL esférica propuesto por Borran (Borhani et al., 1997)

\section{Pre- $\beta$-1 HDL (Fielding and Fielding, 1995)}

Las pre- $\beta-1$ HDL son partículas pequeñas conteniendo solamente apoA-I y pequeña cantidad de fosfolípidos, llamándoselas "lipid Poor", para diferenciarlas de otras pre- $\beta$ discoidales más ricas en lípidos, y de las $\alpha$-HDL; comprenden el 5-8 \% de las HDL en plasma, aunque son mas abundantes en linfa y en líquido intersticial. Tienen un peso molecular de aproximadamente $60-70 \mathrm{kD}$, con un diámetro calculado de 5 a $6 \mathrm{~nm}$. La fracción proteica es solamente apoA-I y la composición lipídica está constituida por lecitina y esfingomielina, en proporciones similares a las encontradas en la membrana plasmática (Cullis and Hope, 1991).

Se ha postulado que la conformación de estas partículas por modelos sintéticos es de pequeños discos o de forma elipsoidal (Luna-Chavez et al., 1994). Con anticuerpos monoclonales se ha encontrado que en las diferentes partículas existen diferentes exposiciones de epitopes, en las pre- $\beta-1$ HDL existe un epitope continuo entre los residuos 
137 y 144 de la apoA-I nativa, siendo que en presencia de estos anticuerpos las pre- $\beta-1$ HDL no pueden remover eficientemente colesterol, en estas partículas se encontró también una susceptibilidad a la proteólisis con trombina cerca del residuo 100 (Kunitake et al., 1990); se predicen en estas regiones giros de tipo $\beta$. Otras regiones de la apoA-I generan epitopes de reconocimiento por anticuerpos monoclonales en estas partículas que incluyen el extremo N-terminal y los residuos comprendidos entre 167-174, pero no existen reconocimiento de la región 93-99 como sí ocurre en otro tipo de partículas discoidales (Marcel et al., 1991),(Marcel and Kiss, 2003).

\section{$\underline{\text { Pre- } \beta-2-\text { HDL Discoidales }}$}

Este tipo de partículas discoidales es un pequeña fracción de las HDL's, la proporción que existe es de alrededor de 2-3\% de las HDL plasmáticas, estando en una proporción mayor en liquido intersticial (Barrans et al., 1996). Exponen a anticuerpos monoclonales en la región cercana a los residuos 99-100, diferentes epitopes a los que se presentan en las pre $\beta-1$, debido a que al ser de mayor tamaño, la interacción lípidoproteína es diferente. También esta región es mas sensible a proteólisis por trombina (Kunitake et al., 1990). Estas presentan heterogeneidad en tamaño, densidad y composición lipídica, pudiendo contener dos o tres moléculas de apoA-I por disco como único componente proteico. No se sabe cuál es la conformación que posee la apoA-I en estos complejos in-vivo, pero se han postulados diferentes modelos, en complejos obtenidos artificialmente (ver más abajo).

Son ricas en lecitina y contienen baja proporción de colesterol y esfingomielina. Las pre $\beta-1$ y las pre $\beta-2$ difieren básicamente en su contenido lipídico, en especial, lecitina y no se detectan ésteres de colesterol (Barrans et al., 1996). 


\section{Aspectos fisiopatológicos en el transporte de colesterol}

Una de las mejores evidencias de la relevancia en el transporte de lípidos mediado por apolipoproteínas surge a partir de estudios con fibroblastos de sujetos con una deficiencia genética llamada enfermedad de Tangier, la cual se caracteriza por una ausencia casi completa de HDL en plasma y de apoA-I, y por acumulación de ésteres de colesterol en diferentes tejidos dado por macrófagos tisulares. La estructura de la apoA-I como de sus productos lipoproteícos son normales, y estudios con cultivos celulares de pacientes con esta enfermedad y a la cual se le agrega apoA-I purificada, demostraron una reducida habilidad para remover colesterol y fosfolípidos de dichas células, lo que implica una severa deficiencia en la formación de HDL, y por lo tanto del transporte reverso de colesterol. Esta enfermedad es autosómica recesiva en donde está modificado el gen que codifica para la proteína integral de membrana mencionada mas arriba, el transportador ABCA1. Este tipo de transportador interacciona con la apoA-I o con sus partículas pobres en lípidos, las preß1-HDL, en las inmediaciones de la membrana en donde se cargarían de fosfolípidos negativos y/o colesterol. Partículas lipoproteicas con apoA-I de sujetos normales tampoco son capaces de remover lípidos de estas células, sugiriendo que existe un deficiente mecanismo de interacción entre las partículas y el ABCA1. También en esta enfermedad existe una deficiente remoción de colesterol mediado por las otras apolipoproteínas como la apoA-II, E y CIII (Remaley and Hoeg, 1995). El transporte reverso de colesterol puede ocurrir además en parte por mecanismos independientes de ABCA1 como ser una difusión pasiva de colesterol desde la superficie celular a las HDLs, y este mecanismo no estaría afectado en esta patología.

El estudio de esta enfermedad aportó datos sobre el metabolismo de lípidos desde los tejidos a todo el cuerpo y ayudó a la interpretación de bases moleculares del mismo, por ejemplo, el hecho que la apoA-I capte deficientemente colesterol y fosfolípidos lleva a un rápido aclaramiento de apoA-I del plasma y por lo tanto a un déficit de HDL esféricas (Fredrickson, 1964),(Assmann et al., 1993), lo que implica que la remoción de lípidos por apolipoproteínas es un requerimiento absoluto para generar incluso bajos niveles de HDL. La ausencia de HDL a su vez tiene implicancia sobre los niveles de otras lipoproteínas, como ser las LDL, que en estos individuos se encuentra a un nivel de $40 \%$ del normal. Los estudios in vitro en cultivos celulares demostraron que las apolipoproteínas libres o pobres en lípidos son las precursoras de este proceso, no requiriéndose ninguna en particular, y 
solamente pequeñas cantidades de las mismas, son capaces de estimular el proceso, lo que permitiría ser regeneradas continuamente.

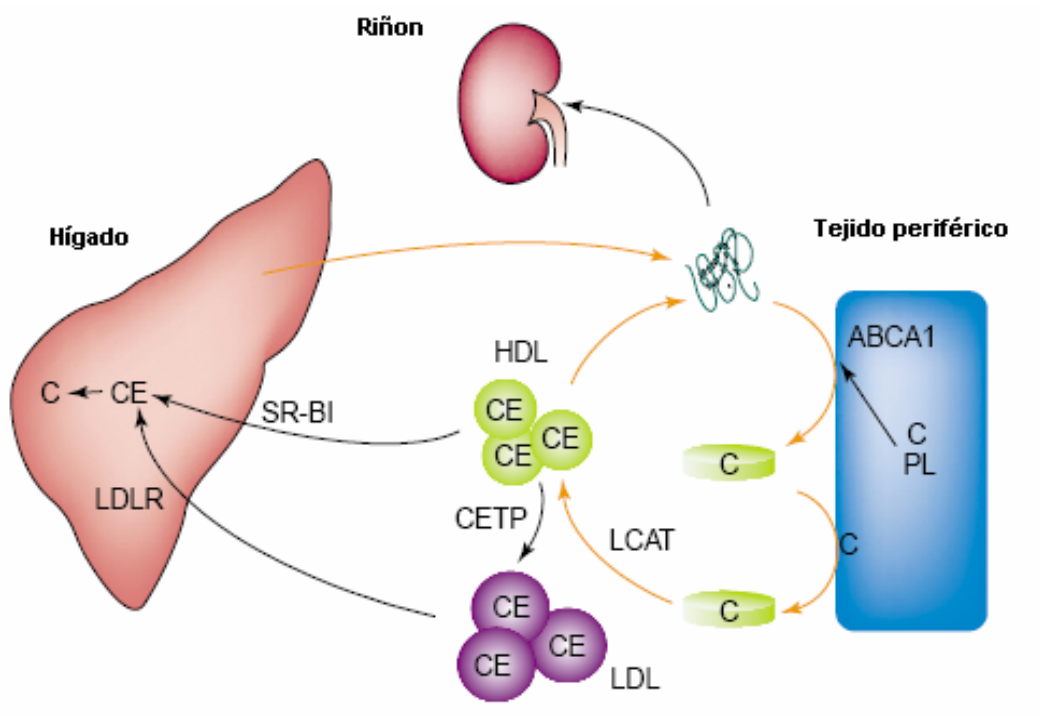

Fig. I-8 a) se muestra en el esquema el transporte reverso de colesterol (Oram, 2002)

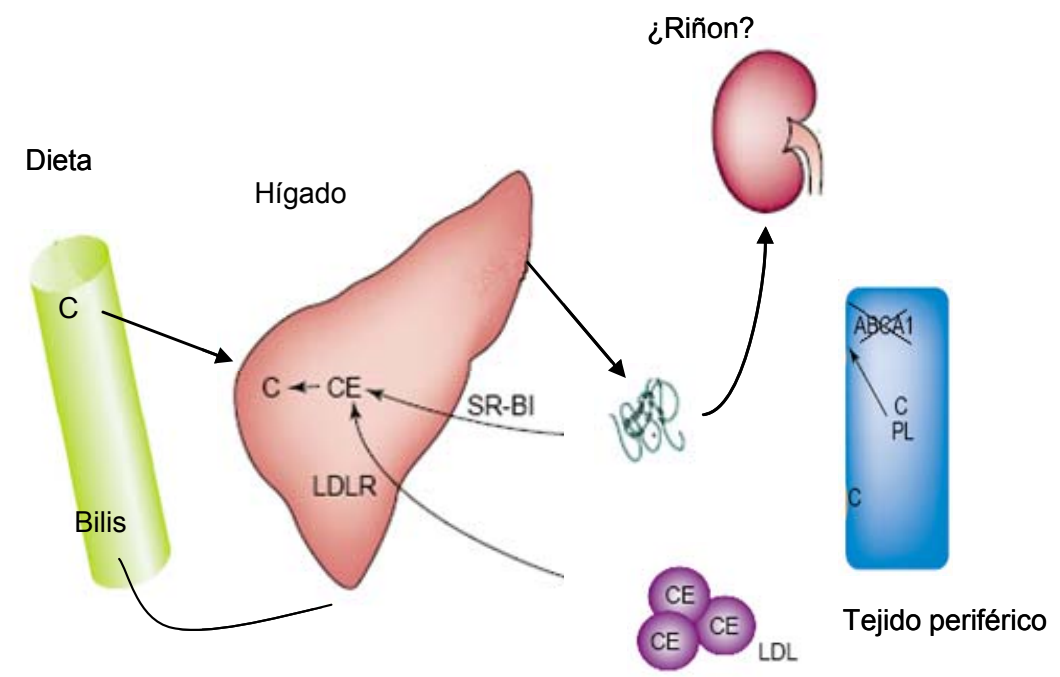

Fig. I-8 b) se muestra el defecto genético que ocurre en la enfermedad de Tangier (Oram, 2002) 
Las figuras anteriores (Fig:I-8 a y b) son las que mejor describen el proceso fisiológico y los trastornos metabólicos de la enfermedad de Tangier. Estos pacientes producen niveles adecuados de apoA-I, pero estas moléculas son incapaces de captar fosfolípidos y colesterol de los tejidos periféricos, dado el defecto en el ABCA1. Así las preß1-HDL nacientes no pueden dar lugar a las HDL discoidales ni a las HDL maduras, incluso inyectando HDL maduras a estos pacientes, las partículas sufren un rápido aclaramiento, probablemente porque las apolipoproteínas se disocian sin poder regenerar HDL maduras (von Eckardstein et al., 1995). Los bajos niveles de LDL en esta patología pueden reflejar además poco intercambio de ésteres de colesterol provenientes de las HDL, como así también una disminución en la remoción de lípidos desde las membranas hacia el hígado, lo que implicaría un aumento de receptores de LDL y por lo tanto un mayor aclaramiento de las partículas en circulación. Aunque la remoción de colesterol se encuentra disminuida, los niveles del mismo en la membrana no se ven alterados, ya que depende de la síntesis y endocitosis de LDL (Brown and Goldstein, 1986). Como el mecanismo de difusión acuosa no se encuentra alterado puede ayudar a evitar la acumulación de colesterol. Los macrófagos pueden acumular ésteres de colesterol porque pueden internalizar partículas lipoproteicas por fagocitosis via receptores, que no están reprimidos en casos de excesos de colesterol, es por este motivo que a pesar de los bajos niveles de colesterol en plasma de estos pacientes, acumulan exceso de colesterol en los macrófagos (Oram, 2000). 


\section{Proteína mayoritaria en las HDL: Apolipoproteína A-I}

La apolipoproteína A-I pertenece al grupo de las apolipoproteínas intercambiables por presentar un equilibrio entre sus formas libres y unidas a lípidos. Pertenecen a este grupo las apolipoproteínas A-II, A-IV, C y E, y la apolipoforina III de insecto. Una característica de las proteínas intercambiables es que están constituidas principalmente por $\alpha$-hélices anfipáticas. En estas se definen distribuciones de cargas y de polaridad que hacen que exista una cara hidrofóbica y otra hidrofílica.

La forma madura de la apoA-I humana contiene 243 aminoácidos, gran parte de su secuencia posee la capacidad de formar $\alpha$-hélices (Segrest et al., 1992).

\section{Secue ncia de aminoácidos y tipos de $\alpha$-hélices anfipáticas en la apolipoproteína A-I humana}
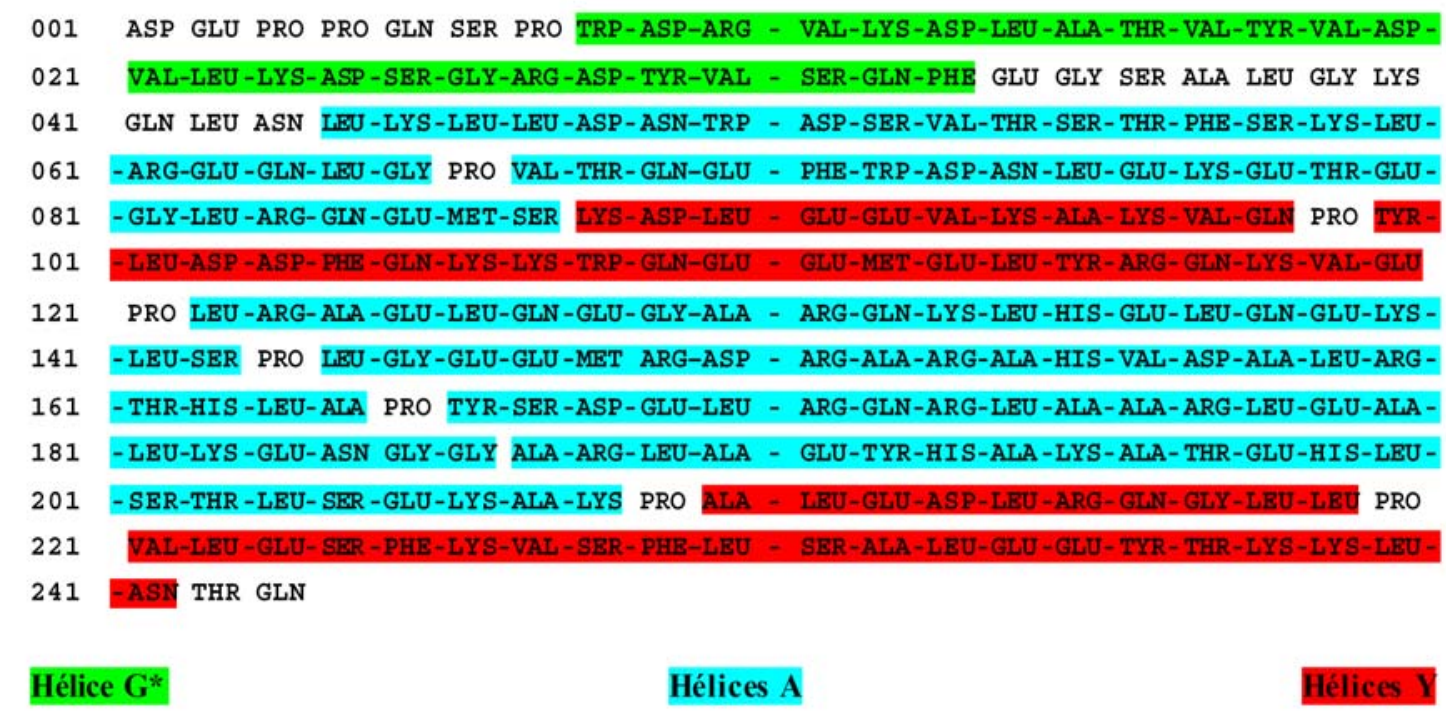

Fig I-9: En el grafico se muestra la secuencia aminoacídica de la apo madura (los aminoácidos nombrados según el codigo de 3 letras).

Por modelado se distinguen tres tipos de hélices anfipáticas en la misma: en el dominio N-Terminal hay una hélice de tipo $\mathrm{G}^{*}$ con un arreglo al azar de los residuos polares como en el caso de las proteínas globulares (marcado en verde en la figura I-9). Se predice también la existencia de 6 hélices tipo "A" (marcado en turquesa), típicas de las apolipoproteínas, en las cuales las cargas positivas se agrupan en la interfase lípido/agua y las cargas negativas en el centro de las caras hidrofílicas. Además la apoA-I presenta dos grupos de dos hélices especiales en el centro y en el extremo $C$, en donde la distribución de 
cargas positivas se asemeja a una "Y", con residuos hidrofílicos positivos en los brazos y con residuos negativos entre los brazos y la base de la "Y".

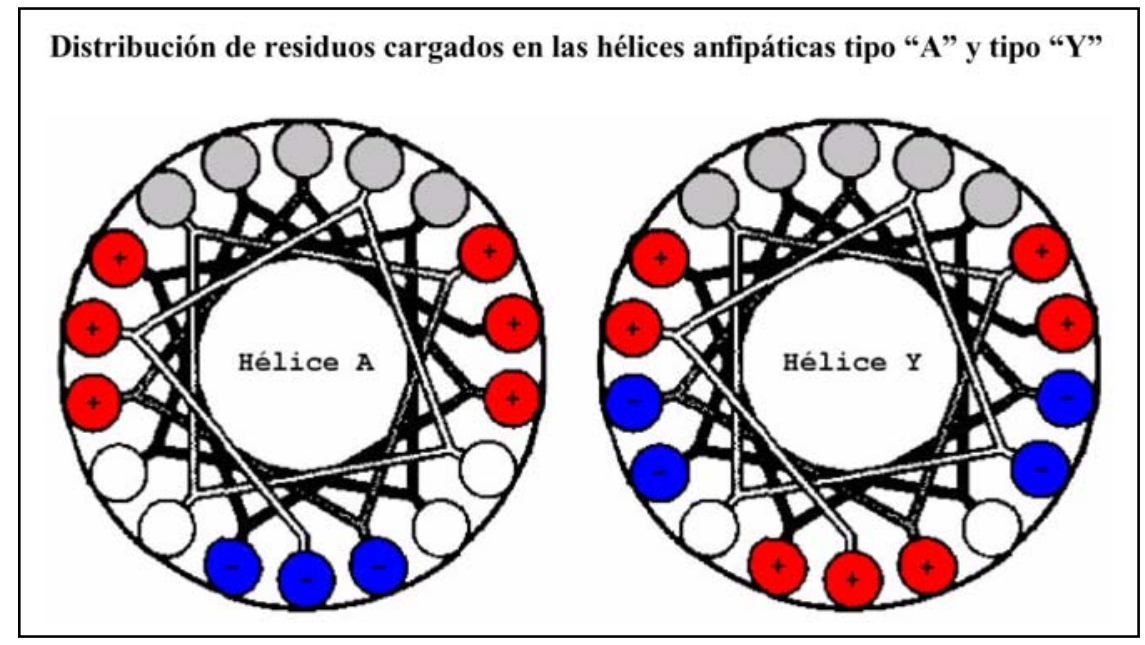

Fig.I-10: En el gráfico se muestra la distribución de cargas en los tipos de $\alpha$ hélices A e Y

Por su gran flexibilidad estructural las apolipoproteínas son muy difíciles de cristalizar, siendo la primera que se logró la apolipoforina III de insecto; de hecho recientemente se ha logrado cristalizar la forma madura de la apoA-I (Ajees et al., 2006). En el año 1997 se cristalizó una forma truncada de la apoA-I, en donde faltan los primeros 43 aminoácidos ( $\Delta 43$ apoA-I) (Borhani et al., 1997), (ver figura I-11); la estructura de la apoA-I truncada, muestra un tetrámero en forma de herradura con un alto contenido de $\alpha$ hélices extendidas. Esta estructura, aunque confirma la existencia de $\alpha$-hélices, no concuerda con los datos de apoA-I en solución ni con la estructura cristalina obtenida recientemente, y estaría más de acuerdo a la estructura que adoptaría la proteína en complejos lipídicos discoidales.
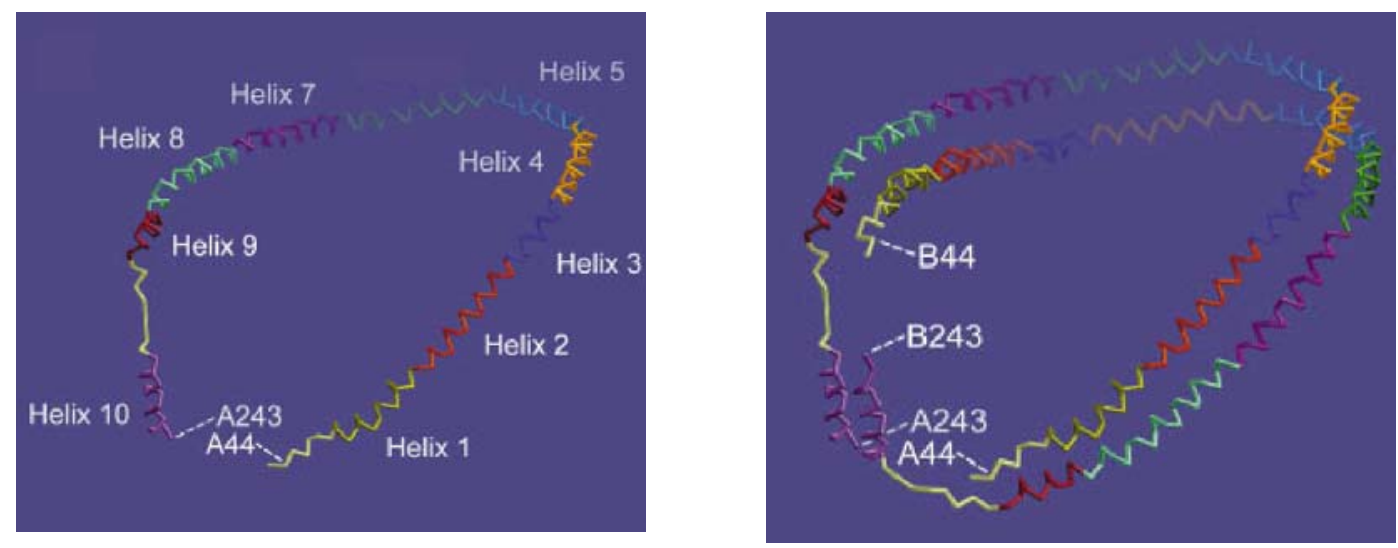


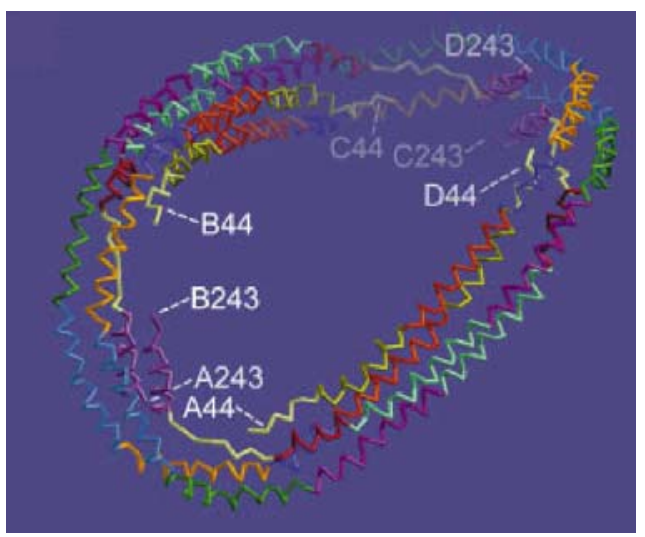

Fig. I-11: Estructura cristalina de la $\Delta 43$ apoA-I, en donde se ven las 10 hélices predichas en la secuencia; en la primera el monómero y como se van agrupando para formar la estructura cristalina, hasta llegar al tetrámero. A, B, C y $\mathrm{D}$ representa cada monómero modelado

Como ya se mencionó, la estructura cristalina de la apoA-I ha sido obtenida recientemente con una resolución de 2,4 Á (Ajees et al., 2006), y consiste en dos dominios de hélices, una primera porción de cuatro hélices que corresponden al extremo N- y abarca 2/3 de la secuencia, y otra región de dos hélices que corresponde al resto de la molécula. En total se identifican seis hélices (A-F) a diferencia de las hélices predichas de la secuencia completa y de la estructura cristalina truncada, y lo notable de la misma es que existen amplias regiones de $\alpha$-hélices con residuos de Prolina, los cuales normalmente se asocian a quiebres o bisagras en las hélices.

El cristal de la apoA-I obtenido recientemente, si bien posee un gran porcentaje en alfa hélices, su estructura difiere de los datos obtenido por Borhani, y de los obtenidos en solución acuosa por Tricerri y otros. Las hélices N-Terminal son estabilizadas por contacto intra molecular, y están conectadas por giros $\beta$. Los que conectan las hélices A-B y las B-C dan movilidad al sistema para que pueda interaccionar con membranas. Las dimensiones de la cada proteina son de 88 × 50 × $27 \AA$, pero si se consideran solamente las cuatro primeras hélices, las dimensiones cambian a 88 × $25 \times 27 \AA ̊$, similar al dominio NTerminal de apoE (Wilson et al., 1991) (ver FiguraI-12). 


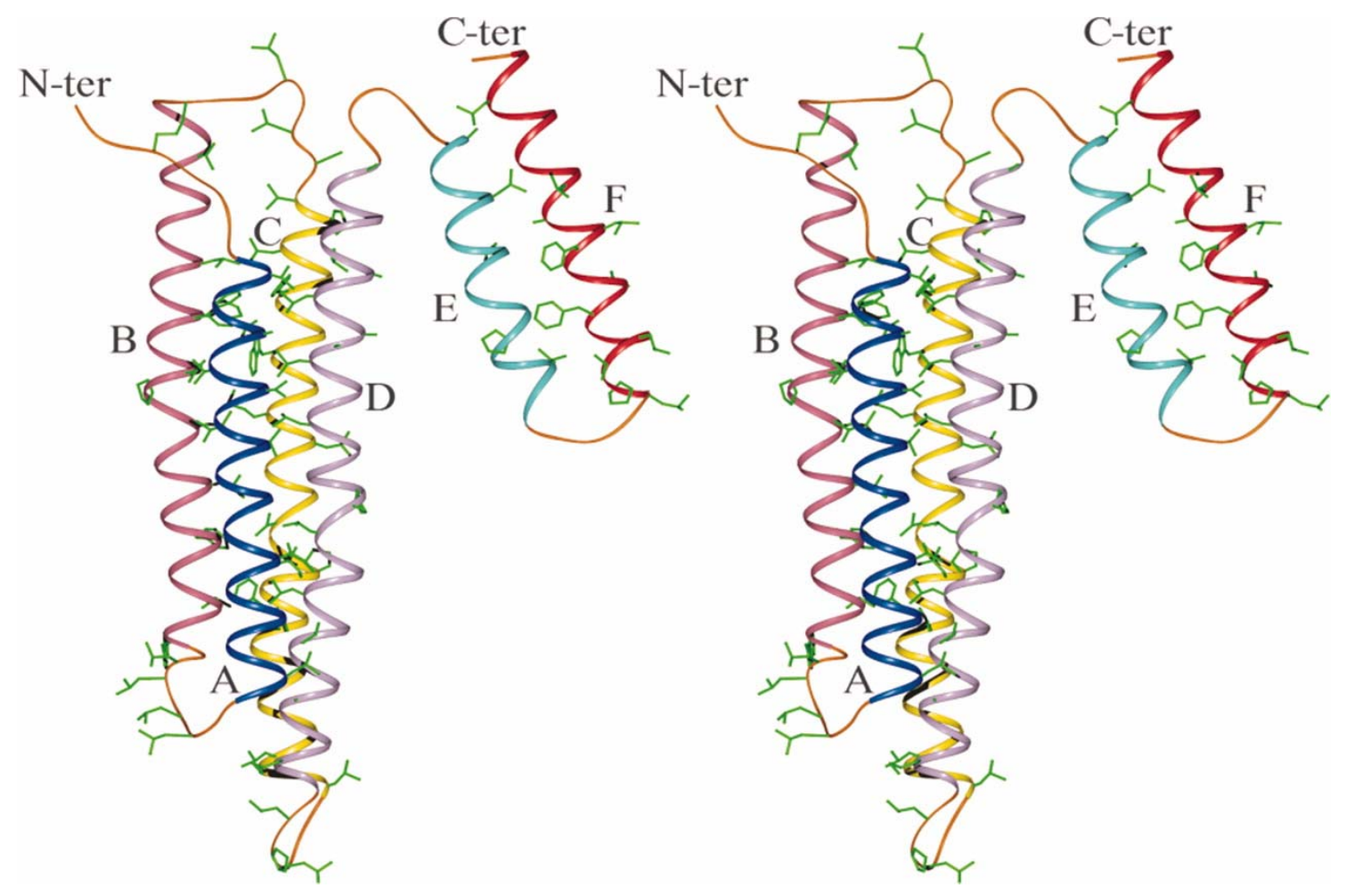

Fig. I-12: Arriba: Estructura cristalina de la apoA-I (Ajees et al., 2006) Abajo: Estructura del cristal

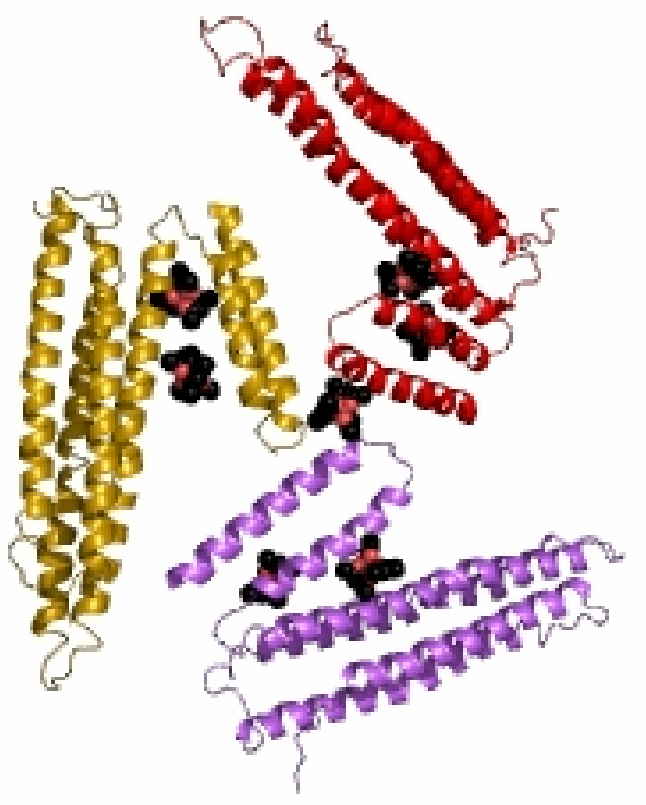

En solución apoA-I se considera que posee estructura super secundaria o de "glóbulo fundido" (Gursky and Atkinson, 1996), con un 50-76\% de contenido de $\alpha$-hélice, dependiendo de su asociación con lípidos; a altas concentraciones tiende a agregarse, por lo que se dificulta su cristalización. En cambio la estructura cristalizada predice un $82 \%$ de 
estructura helicoidal. Esta no es la única diferencia que se encuentra entre la estructura cristalina y otros datos experimentales, ya que además en solución se determinó mediante experimentos con mutantes y transferencia de energía (FRET) (Tricerri et al., 2000), (Behling Agree et al., 2002) (Silva et al., 2005b) y análisis con agentes entrecruzantes que se trata de un toroide cuya relación entre el eje mayor y menor es de 5/1, estando los dominios $\mathrm{N}$ - y C- Terminal cercanos entre sí y que sus hélices estarían formando un ramillete; todo esto sugirió que la estructura cristalina encontrada sería una de las conformaciones que la proteína puede tomar en solución, previa a adquirir la estructura final de los discos, similar a la estructura de la proteína con la secuencia truncada.
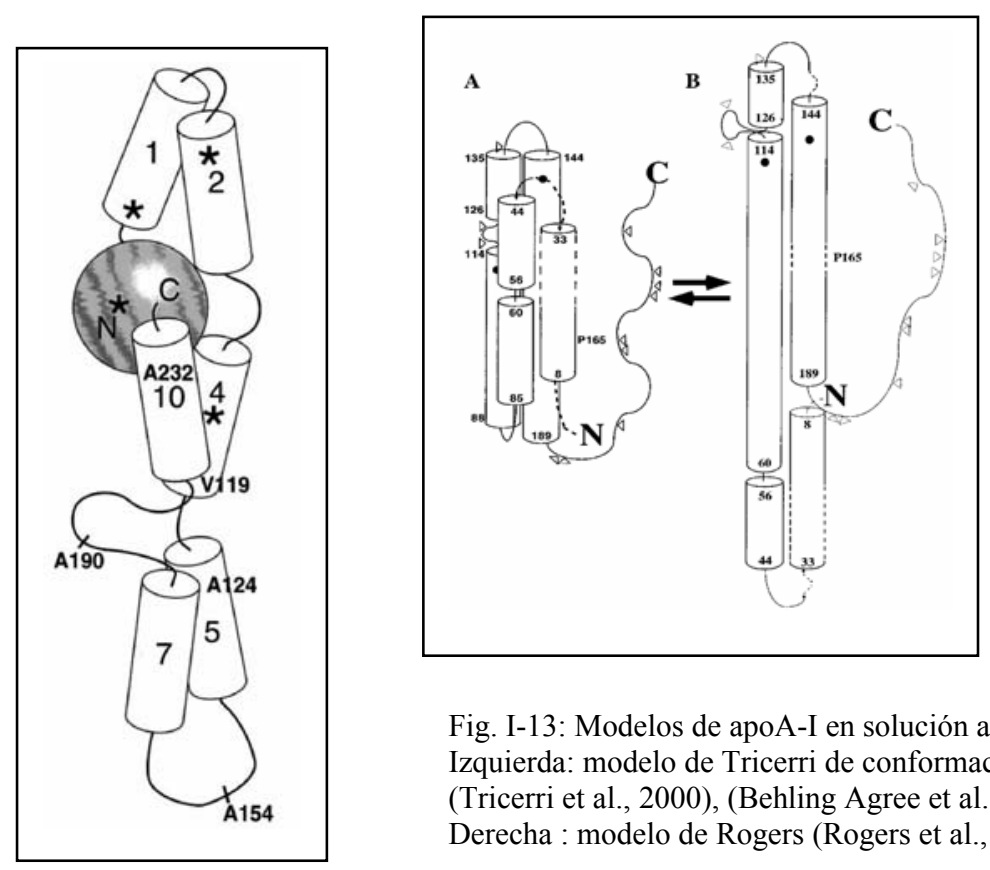

Fig. I-13: Modelos de apoA-I en solución acuosa Izquierda: modelo de Tricerri de conformación en solución acuosa (Tricerri et al., 2000), (Behling Agree et al., 2002)

Derecha : modelo de Rogers (Rogers et al., 1998)

En el análisis global también se identifican en la estructura cristalina regiones hidrofóbicas y regiones de cargas negativas y positivas que tienen implicancias en las interacciones con membranas con ABCA1 y con los SR-B1.

\section{Interacción de apoA-I y de complejos lipoproteicos de apoA-I con membranas lipídicas}

La teoría clásica del mosaico fluido de las membranas biológicas, (Singer and Nicolson, 1972) en la cual los lipidos se encuentran organizados en una fase fluida homogénea, ha evolucionado hacia un concepto mas dinámico, indicando un arreglo heterogéneo de los lípidos presentes en una membrana. Por ejemplo, se postula la existencia de dominios típicos en las membranas naturales que son resistentes a la 
disolución con detergentes, ricos en glicoesfingolípidos y colesterol. Dichos dominios pueden modificar o regular la interacción lípido-proteínas y por lo tanto mediar en procesos de señalización y difusión.

Es sabido que las interacciones de la apoA-I con membranas dependen tanto del micro ambiente de lípidos, como ser la composición y estado de la membrana (Yokoyama et al., 1980) (Arnulphi et al., 2004), como de la conformación de la proteína (libre de lípidos ó parcialmente lipidada). La proteína libre puede unirse a membranas de fosfolípidos zwiteriónicos en estado líquido cristalino pero solamente a temperatura de transición de fase puede la interacción resultar en una rápida captación $\mathrm{o}$ microsolubilización de fosfolípidos generando complejos discoidales (Ji and Jonas, 1995). Este requerimiento sugiere que debe haber coexistencia de dominios separados lateralmente en donde defectos de empaquetamiento de los lípidos en la membrana facilitan que la apoA-I pueda interaccionar y posteriormente formar los complejos mencionados; el colesterol es capaz de inhibir este proceso, debido a que es capaz de atenuar la transición de fase.

En nuestro laboratorio se demostró, con sistema de lípidos binarios, que esta reacción ocurre cuando coexisten dominios de gel y líquido-cristalino y no ocurre cuando coexisten diferentes dominios en estado fluido o líquido-cristalino y líquido-ordenado. Usando mezclas de dimiristoil y diesteroil- fosfatidil colina (DMPC-DSPC) que presentan coexistencia de fases en un amplio rango, se detectó que la reacción ocurre en el límite inferior del diagrama de fases en donde se observa, mediante visualización de vesículas gigantes por microscopía de fluorescencia de dos fotones, la desaparición de los dominios más fluidos a medida que la apo interacciona (Tricerri et al., 2005). Estos datos sugieren que la reacción requiere pequeños dominios en fase fluida en una fase continua de gel. Del análisis de los productos formados, se confirmó que la remoción de fosfolípidos proviene preferencialmente de los dominios líquido-cristalino. 


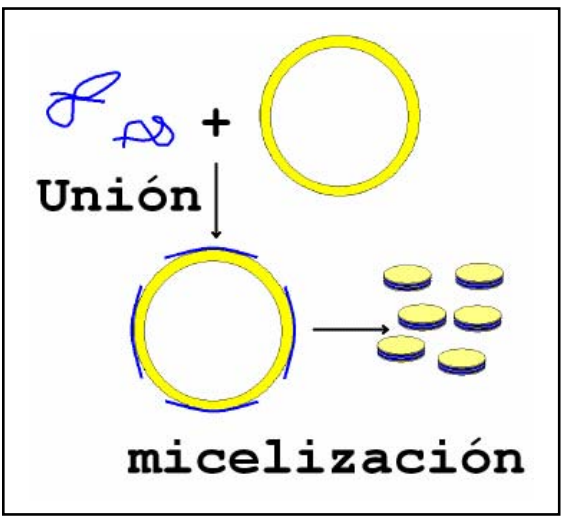

Fig. I-14: Reacción de micelización.

En la temperatura de transición de fase (gel/líquido-cristalino), se produce la disrupción de la vesícula y la formación de HDL discoidales.

Esta reacción es desfavorecida por colesterol, pero favorecida por fosfolípidos de carga negativa

La apoA-I o sus complejos lipoproteicos pueden igualmente interaccionar con membranas en estado líquido cristalino sin que ocurra un proceso de micelización, siendo este proceso de gran importancia en el intercambio de colesterol entre las HDL y las membranas. La presencia de colesterol en las membranas favorece la unión de la apoA-I (Yokoyama et al., 1980), y ya en 1992 se había postulado que un segmento flexible de apoA-I (Rothblat et al., 1992) quedaría disponible en los complejos discoidales para interaccionar con membranas y favorecer el intercambio de colesterol. Este segmento no quedaría disponible en las $\alpha$-HDL ya que estaría en estrecho contacto con los lípidos de la esfera y no puede interactuar con membranas. Así el cambio conformacional que sufre apoA-I en pasar de estado libre de lípidos, luego a complejos discoidales y por último a partículas esféricas determinaría una disminución de la afinidad por membranas y la liberación a circulación de $\alpha$-HDL. El inconveniente de esta hipótesis es que se requeriría la presencia de LCAT para la conversión de discos en HDL esféricas (Rothblat et al., 1992), y esta enzima no existe en el líquido intersticial.

Una de las formas de caracterizar interacción con membranas es midiendo la pérdida de compuestos hidrosolubles que se encuentran en el espacio acuoso de vesículas lipídicas. Tanto apoA-I libre como complejos lipoproteicos discoidales inducen una pérdida transitoria del contenido acuoso, atribuido a una desestabilización temporaria de la membrana debido a la inserción de algún dominio de la apoA-I (Tricerri et al., 1998). La apoA-I libre y complejos discoidales más pequeños y sin colesterol fueron los más eficientes para el proceso, además la presencia de colesterol en las membranas aumentó la pérdida de agua (Tricerri et al., 1998). En otros estudios se demostró que lo discos de menor tamaños son los que tienen mayor afinidad por las vesículas (Tricerri et al., 2002), y favorecen también el intercambio de colesterol, estando correlacionado por una mayor 
afinidad a membranas, lo que hace sugerir que una porción de apoA-I favorece el anclaje y posterior intercambio de colesterol entre ellas y las partículas.

Estos hechos y el que no existe LCAT en el líquido intersticial dieron razón para modificar la hipótesis original de Rothblat (Rothblat et al., 1992) en el sentido en que el aumento de tamaño y contenido de colesterol de los discos, en lugar del cambio morfológico de discos a esfera, sería el ó los factores que producirían un cambio conformacional de la apoA-I que disminuye su afinidad por membranas, liberando al plasma grandes discos de HDL enriquecidos con colesterol. Este mecanismo no requiere la presencia de LCAT en el espacio intersticial y tendría importancia fisiológica, ya que las pequeñas partículas de apoA-I pobremente lipidadas por ABCA1 podrían entonces unirse a las caveolas y cargarse de lípidos y colesterol para luego liberarse a circulación para ser un buen sustrato de LCAT.

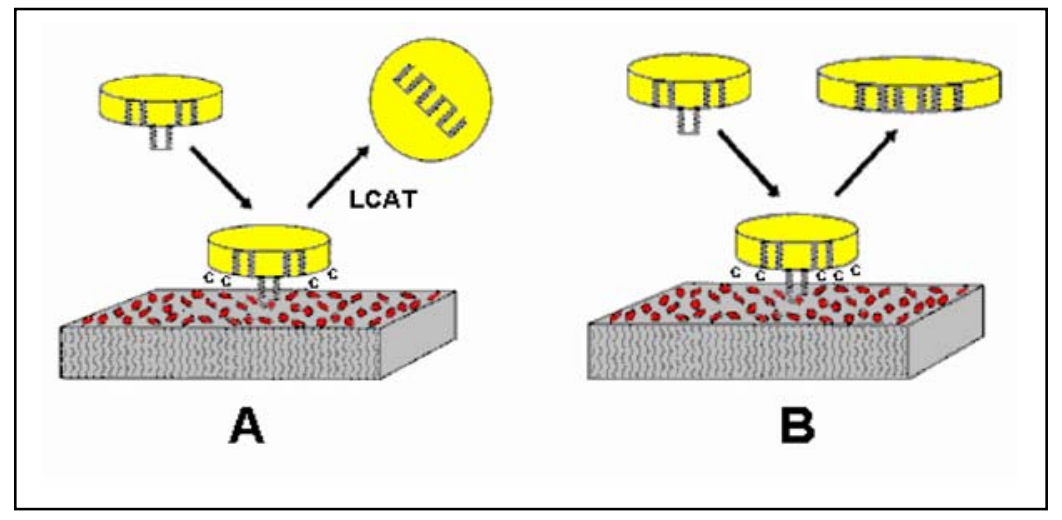

Fig. I-15: A) Hipótesis de Rothblat et al. (Rothblat et al., 1992) B) Hipótesis modificada en base a nuestros resultados (Tricerri, 1998, Tesis Doctoral; (Fielding and Fielding, 2001); (Tricerri et al., 1998); (Toledo et al., 2000) 


\section{Conformación de la apoA-I en complejos discoidales}

Las HDL discoidales y las pre- $\beta$ de pequeño tamaño, son las primeras partículas que se liberan por el hígado y células intestinales, y consisten en una bicapa fosfolipídica que no puede existir si no son estabilizadas sus regiones hidrofóbicas por proteínas, y la apoA-I entre otras apolipoproteínas, puede realizar esta tarea. Su espesor es similar al de las membranas, aproximadamente 54 Á, pero su diámetro depende de la relación entre lípidos y proteínas.

A fin de estudiar el metabolismo de las HDL plasmáticas se desarrollaron y caracterizaron partículas artificiales que sirvan de modelo a las distintas HDL. Uno de los métodos fue explicado más arriba, en donde la apoA-I "aprovecha" los defectos de estructura a temperatura de transición de fases de los fosfolípidos. El inconveniente de esta técnica es que está acotada a unos pocos fosfolípidos, cuya temperatura de transición está en un rango conveniente de trabajo, como ser DMPC. Otra técnica ó metodología para obtener estos discos es por diálisis, en donde se agrega a una mezcla de lípido requerida, una cantidad determinada de un detergente dializable, como ser el colato de sodio (ver materiales y métodos), en un primer momento el colato estabiliza las cadena hidrofóbicas favoreciendo la formación de complejos con estructura plana tipo bicapa, y luego el agregado de apoA-I, desplaza al detergente, ayudado por el gradiente químico que se forma en el proceso de diálisis (Jonas et al., 1989).

Se pueden formar discos de diferentes tamaños pudiendo variar en la cantidad de apoA-I (dos o tres moléculas por partícula) o en la cantidad de lípidos, pudiendo haber partículas con la misma cantidad de proteína y distinta cantidad de fosfolípidos, denominándose Rn-m, en donde "n” significa la cantidad de proteína que constituye el disco y "m" da idea de la cantidad de fosfolipídos que posee o del radio de Stokes. Cuanto mayor es la cantidad de fosfolípidos, mayor es el diámetro y mayor es el número “m”.

Las partículas más caracterizadas son las que poseen dos moléculas de apoA-I, principalmente por ser las precursoras de las HDL esféricas, y los diámetros son 77 Á (R21), $88 \AA$ Á (R2-2), $98 \AA \hat{A}$ (R2-3), $106 \AA$ (R2-4) y 110 Á (R2-5), (Li et al., 2004) requiriéndose una estequiometría mínima para la formación de las partículas. En las partículas con el mismo número de moléculas de apo, el cambio de diámetro no es continuo, sino en forma discreta a lo largo de una o dos hélices, lo que sugirió, junto con los resultados de anticuerpos monoclonales, la presencia de regiones "bisagra" de alta flexibilidad, que al estar en conformaciones alternativas, ya sea abiertas o cerradas, permitiría que diferente 
número de hélices estén expuestas al medio acuoso ó en contacto con los lípidos del borde de los discos, respectivamente.

Los discos que poseen dos apoA-I por moléculas, están bien caracterizados (Jonas et al., 1990); (Gursky and Atkinson, 1996) dos tipo de diámetros de Stokes de 78 y 96 Á, con alrededor de 30 y 70 moles de fosfolípidos por mol de apoA-I, respectivamente. La conformación de la apoA-I en estas partículas es diferente (Bergeron et al., 1995) y (McGuire et al., 1996) teniendo implicancia fisiológica, las de menor diámetro son unas 60 veces mas afines a los receptores de SR-BI (Jonas et al, 1989) y poseen $\sim 16$ veces menor capacidad de activar a LCAT. (de Beer et al., 2001a); (de Beer et al., 2001b). La forma truncada de la proteína no puede formar los discos de mayor tamaño de la serie mencionada (Li et al., 2004), y sí lo puede hacer cuando se agrega la región faltante al armar estas partículas por diálisis.

Cualquier modelo propuesto para la conformación de la proteína en los discos se debe basar en la existencia de hélices anfipáticas y los motivos de mayor asociación a lípidos, en la geometría planar de los discos, la diferencia de polaridad entre los lípidos y el solvente, como así también en los posibles puentes de hidrógeno o salinos inter e intramoleculares.

Uno de los primeros modelos que explicaba la conformación de los discos proponía (Phillips et al., 1997) que las hélices de dos apoA-I se orientaban en los discos en forma paralela a las cadenas hidrocarbonadas, y rodeando en forma de "empalizada" aproximadamente 160 moléculas de fosfolípidos, en este modelo las repeticiones helicoidales de apoA-I constituidas por 22 residuos abarcaban prácticamente la totalidad del espesor de la membrana, además de explicar la presencia de prolinas en la unión a lípidos a intervalos regulares (Ver fig. I-16). 


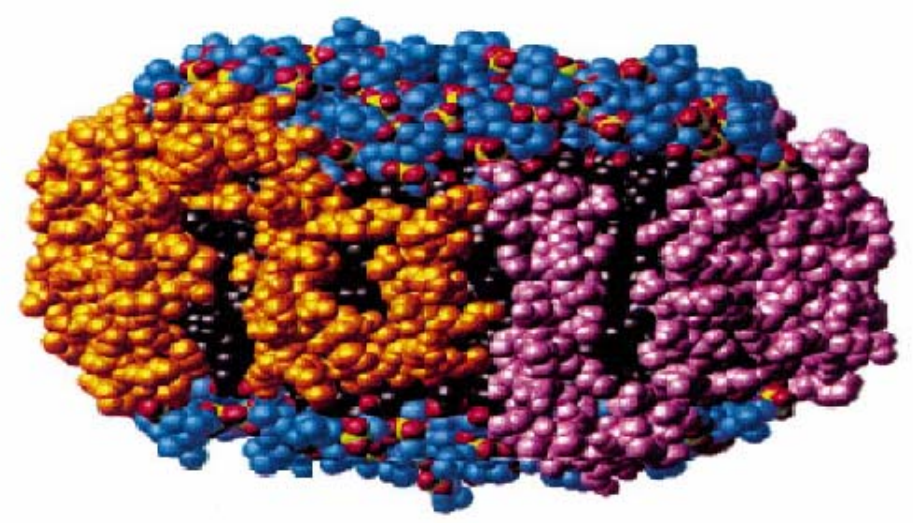

Fig I-16: .Modelo del cerco

(Phillips et al., 1997)

Este modelo fue muy aceptado durante aproximadamente 20 años, pero se empezó a cuestionar con la obtención de la estructura cristalina de la apo truncada (Borhani et al., 1997), Luego, trabajando con mutantes simples de triptofano en las posiciones 108 y 115 en la mitad de la secuencia de la proteína, pertenecientes a la hélice "4" pero a diferentes alturas (Maiorano and Davidson, 2000), observaron que la fluorescencia intrínseca de ambos residuos en los discos era quencheada o apagada en similar extensión por agentes ubicados en la región central de la bicapa, sugiriendo que por lo menos esta región debería estar ubicada en forma perpendicular a la cadena hidrocarbonada. El modelo de empalizada tampoco podía explicar otros datos experimentales comos los de Li y Tricerri (Li et al., 2000),(Tricerri et al., 2001) realizados con técnicas espectroscópicas de FRET y usando mutantes puntuales marcados específicamente en distintas posiciones, los cuales indicaban que el eje de las hélices se disponían paralelo a la superficie de la partícula.

Se mencionó anteriormente que la estructura cristalina de una forma truncada de apoA-I fue cristalizada antes que la estructura entera, y esta presentaba una estructura circular, muy parecida en las dimensiones a las de los discos El estudio con agentes entrecruzantes y proteólisis parcial y posterior estudio de estos fragmentos hizo proponer a los investigadores Li , Davidson y Segrest (Segrest et al., 1999) que dos apoA-I se ubicarían en estas partículas en forma de cinturón ("Belt Model"), ya sea en forma de dos cadenas paralelas (ver figura I-14) o en forma de "Z", estando las hélices 5 y 6 de diferentes moléculas muy próximas e interactuando entre si. (Silva et al., 2005b). 

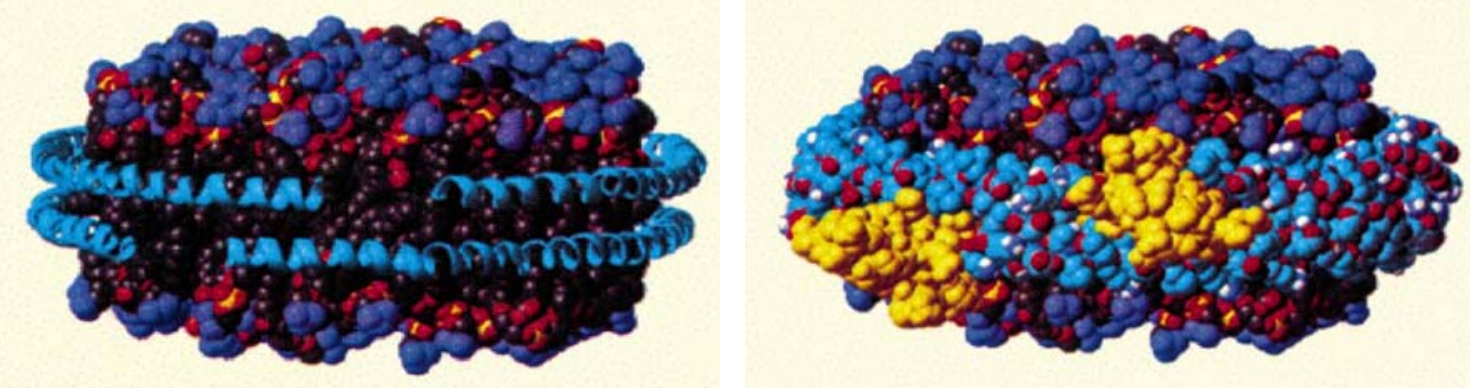

Fig I-17: Modelos del cinturón (Segrest et al., 1999)

Otros modelos son propuestos para la ubicación de la apoA-I, en donde ésta se plegaría en aproximadamente la mitad de la proteína involucrando a diferencia de los otros modelos a las hélices " 3 " y " 4 ” y adquiriendo una forma de hebilla, y dos de estas hebillas rodearían el borde del disco (Tricerri et al., 2001) planteándose una interacción de tipo cabeza-cabeza o cabeza-cola (figura I-18).
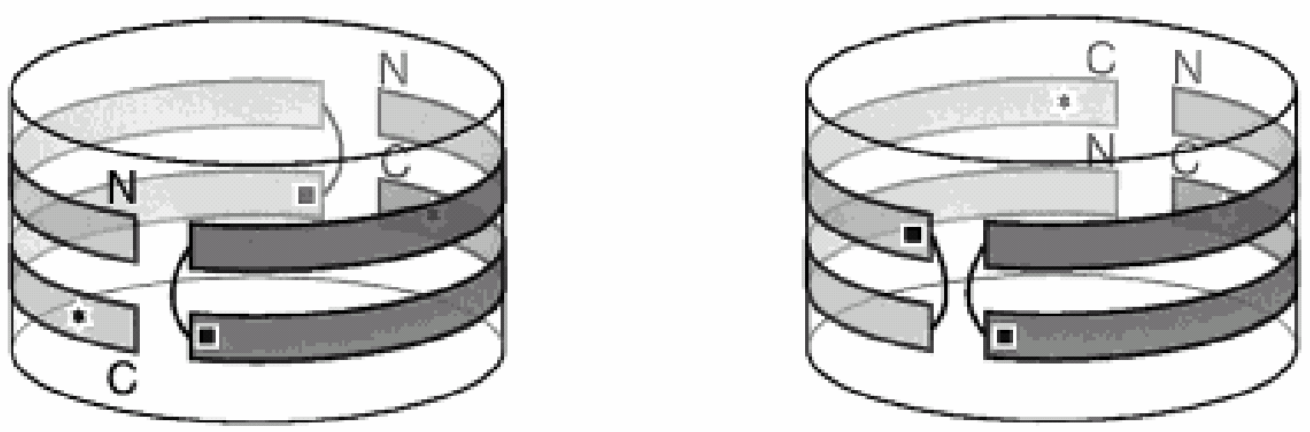

Fig. I-18 Modelos deTricerri et al (Tricerri et al., 2001) 
Luego, Silva y colaboradores (Silva et al., 2005a), analizaron las regiones helicoidales que interaccionan entre si en los discos. Mediante el uso de reactivos entrecruzantes de Lisina y con posterior proteólisis, obtuvieron evidencias que soportan el modelo de cinturón aunque también detectan la coexistencia de dos configuraciones que varían en el registro de la hélices: en una de ellas (configuración 5/5) quedarían enfrentadas entre si las hélices 5 de cada apo A-I, mientras que en la segunda (configuración 2/5) le hélice 2 de una molécula de apoA-I queda enfrentada a la hélice 5 de la otra molécula.

Básicamente estos son los modelos que existen en la actualidad que explican cuál es la conformación de la apoA-I en los discos, pero por más que las distintas técnicas avalan uno ú otro, no se sabe con certeza cuál de ellas son los que realmente se liberan invivo, ya que los experimentos in vitro no pueden descartar ninguna de las posibilidades de modelos propuestos.

\section{La región central de la apoA-I}

El hecho que tanto la apoA-I como partículas discoidales (las de menor tamaño y libres de colesterol) son capaces de inducir pérdida parcial de contenido en vesículas, hizo sugerir en nuestro grupo que existe una región de la proteína que es la encargada del anclaje en membranas y se insertaría profundamente en las mismas. La detección de dicho fragmento se logró utilizando un reactivo fotoactivable marcado radiactivamente con ${ }^{125} \mathrm{I}_{2}$ (Corsico et al., 2001). Estos grupos fotoactivables particionan en fase lipídica y consiste en un grupo Diazirina que por fotólisis se reordena a carbeno, especie capaz de reaccionar con cualquier sustancia que posea un enlace químico, así las regiones en contacto con lípidos o inserta en ellos serán radiomarcadas cuando se iluminan en presencia de estos reactivos (figura I-19).
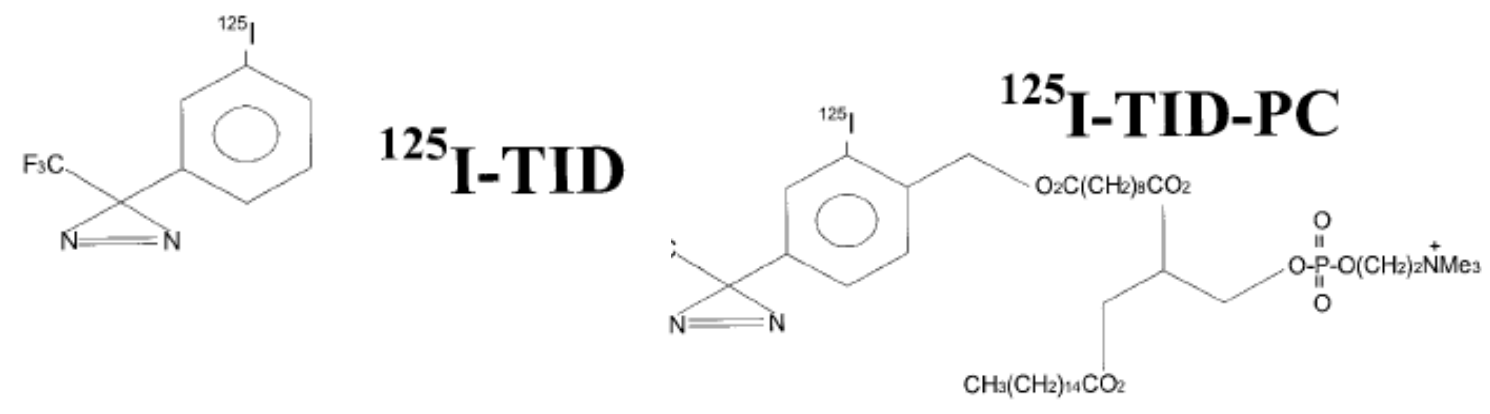

Fig. I-19: Reactivos fotoactivables 
Luego de fotolizar la muestra en contacto con este reactivo se deslipidizó, y clivó químicamente con bromuro de cianógeno ( $\mathrm{CNBr}$, o hidroxilamina), luego los fragmentos peptídicos obtenidos fueron separados por electroforesis de poliacrilamida, y posterior análisis de su secuencia N-Terminal, y la distribución de radioactividad analizada por auto radiografía. El reactivo ${ }^{125}$ I-TID fue utilizado para determinar qué región de la apoA-I tenía menor contacto con los lípidos del disco, encontrándose que, de los diferentes fragmentos que rinde la proteólisis con $\mathrm{CNBr}(1-86,87-112,113-184,185-243)$, los péptidos 87-112 y 185-243 (pertenecientes a la región central y al C-Terminal) son los que poseen menor contacto con los lípidos de los discos.

Al utilizar ${ }^{125}$ I-TID-PC/16 en vesículas, el cual tiene poco intercambio, para determinar cuál es la región de apoA-I que se inserta en membranas, se encontró que solamente el fragmento 87-112 aparece radio marcado cuando se enfrentan las vesículas a la proteína libre de lípidos o a complejos discoidales. Estos resultados permitieron concluir que existen dos regiones que no están en contacto con lípidos de los discos y que además la región central que involucraría las dos hélices "Y" centrales 3 y 4, serían las que interaccionan con los lípidos de las membranas.

El análisis de la región de las hélices "Y" centrales de apoA-I con el programa PSSM reportó que la misma posee un alto grado de analogía estructural con una toxina peptídica (Kelley et al., 2000) de $7.9 \mathrm{kD}$ llamada ectatomin, cuya estructura en solución fue resuelta por RMN (Nolde et al., 1995). Ésta toxina consiste de dos cadena homólogas de 34 y 37 residuos de conformación similar. Cada una consiste de dos hélices y una región bisagra de cuatro residuos, dando una estructura total de un ramillete de cuatro hélices. Al insertarse en membranas dos moléculas de ectatomin forman un canal iónico gracias a una considerable reorganización de su estructura.

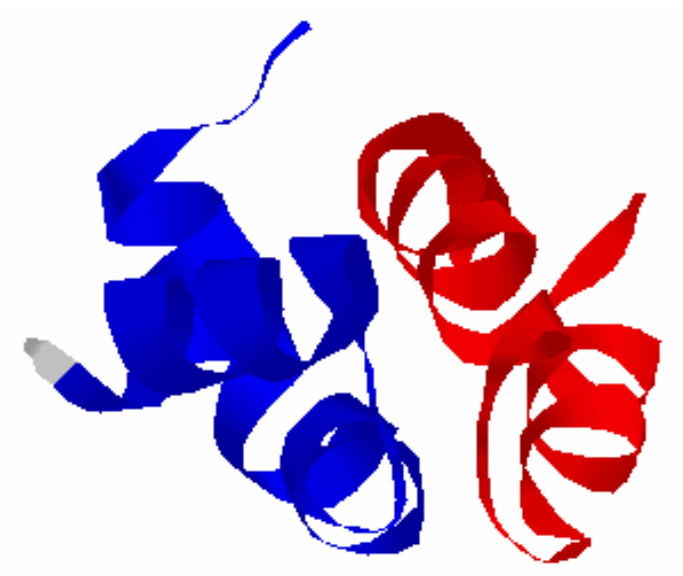

Fig. I-20: Ectatomin, una toxina peptídica de 7,9 $\mathrm{kD}$ cuya estructura es conocida por NMR (Nolde et al., 1995). $\mathrm{y}$ que se inserta en membranas para formar un canal iónico (Pluzhnikov et al., 1999) 


\section{CAPÍTULO II:}

HIPÓTESIS CENTRAL Y OBJETIVOS GENERALES DEL TRABAJO 


\section{Hipótesis central y objetivos generales del trabajo}

Como se mencionó en la introducción, experimentos previos de este laboratorio con reactivos fotoactivables (Corsico et al., 2001) mostraron que la región del par de hélices Y centrales de apoA-I es la única que se inserta profundamente en la membrana de vesículas lipídicas, ya sea cuando estas vesículas son enfrentadas con apoA-I libre de lípidos o con apoA-I en la forma de complejos lipoproteicos discoidales (rHDL). En las rHDL, sin embargo, esta región tiene relativamente poco contacto o interacción con los lípidos. Este hecho, más la analogía predicha con ectatomin (una toxina hidrosoluble que se inserta en membranas para formar un canal iónico), nos indujo a proponer la hipótesis de que estas hélices centrales podrían comportarse como un dominio estructural y funcionalmente independiente del resto de la molécula de apoA-I que mediaría la unión de las HDL discoidales a membranas y facilitaría el intercambio de colesterol.

El análisis de las dos hélices Y centrales de apoA-I (separadas por el residuo de prolina 99) indica que sus caras hidrofóbicas son bastante más angostas que las caras hidrofílicas (ver Figura II-1). Esto permite predecir que la interacción entre las caras hidrofóbicas de estas hélices sería suficiente para que los residuos no polares queden excluídos del entorno acuoso cuando estas hélices quedan separado de los lípidos en las HDL discoidales (Fig II-1 A). Así, es razonable asumir la hipótesis de que en las HDL discoidales, estas hélices puedan encontrarse en equilibrio entre una forma débilmente unida a los lípidos y una forma "despegada" de los mismos, lo que explicaría su relativamente baja accesibilidad a reactivos fotoactivables incorporados en los discos (Corsico et al., 2001).

Para insertarse en membranas, al menos dos modos serían posible (ver fig.II-2): El primer modo de inserción posible sería la penetración de un ramillete de hélices con su eje mayor paralelo a las cadenas hidrocarbonadas de los fosfolípidos (fig. II- 2). Este modo es muy improbable de ocurrir sólo con las dos hélices $\mathrm{Y}$ del dominio central ya que por el ancho de las caras hidrofílicas sería imposible excluir a todos los residuos polares del contacto con el entorno hidrofóbico del interior de la membrana. Sin embargo, esto sería en principio posible con un ramillete de al menos 4 hélices como ocurre en el caso de ectatomin y muchas proteínas que forman canales en membranas. ApoA-I forma dímeros y mayores oligómeros en solución acuosa dependiendo de la concentración, pero su estructura cuaternaria en el estado unido a membrana es desconocido. En las HDL discoidales, un ramillete de 4 hélices Y centrales sería posible si estas se encontraran 
cercanas entre sí como lo indican algunas evidencias (Tricerri et al., 2001),(Davidson and Hilliard, 2003).

A

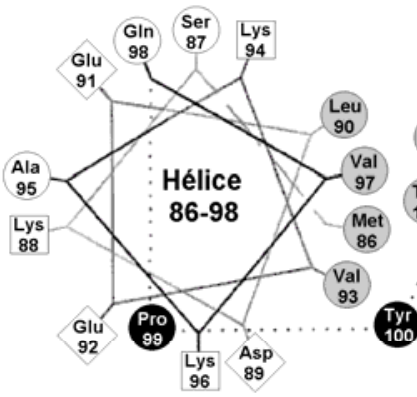

Tyr

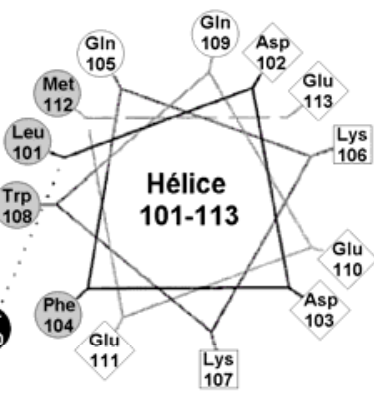

B
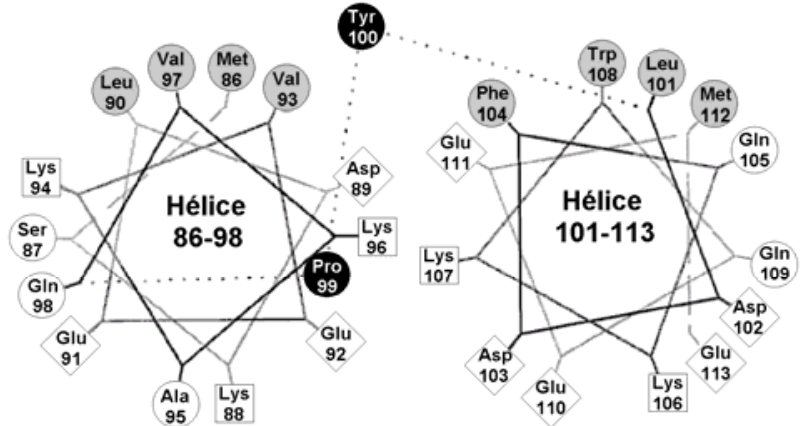

Residuo hidrofóbico

Residuo neutro
Residuo fuera de la región helicoidal
Fig.II-1: Probable configuración de las hélices $\mathrm{Y}$ centrales de apoAI en las HDL discoidales libres (A) y en HDL discoidales ancladas a membranas (B).
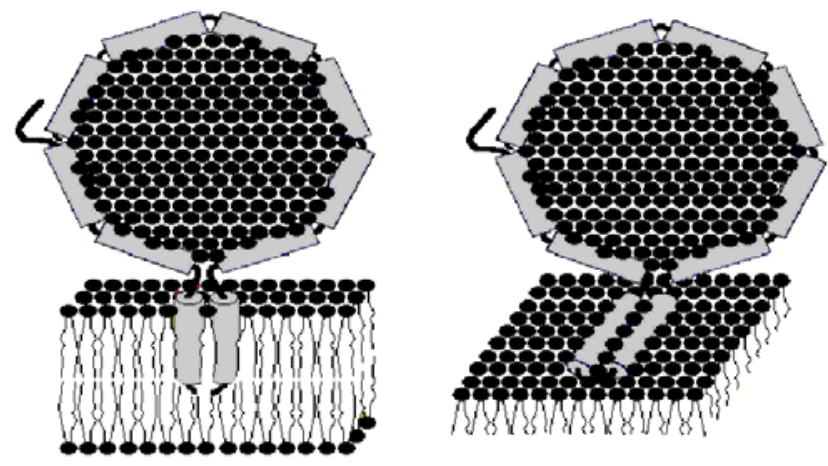

Fig. II-2: Dos modos probables de inserción del dominio central de apoAI en membranas. Aquí se muestra a apoA-I como formando parte de HDL discoidales

B) El segundo modo de inserción posible es la interacción de las hélices $\mathrm{Y}$ centrales con su eje mayor paralelo a la superficie de la membrana insertando la cara hidrofóbica entre los lípidos (Fig II-2). Esta es la manera que se ha propuesto para la disposición de todas las hélices anfipáticas de apoA-I y otras apolipoproteínas intercambiables en la superficie de lipoproteínas esféricas (Segrest et al., 1992) por lo que se supone sería el modo preferible de interacción para la mayoría de las hélices de apoA-I cuando esta interactúan con una membrana. Sin embargo, el hecho de que sólo las hélices $\mathrm{Y}$ centrales sean marcadas por el reactivo ${ }^{125} \mathrm{I}-\mathrm{TID} / \mathrm{PC}$ indica que éstas se insertan a mayor 
profundidad, o que de alguna manera se diferencian en su conformación quedando mucho más accesibles al reactivo que el resto de las hélices. Este modo requeriría que respecto al estado libre, cada hélice gire unos $90^{\circ}$ en sentido contrario a la otra para permitir la inserción en la membrana (Fig. II-1 B).

El primer objetivo de este trabajo de tesis fue ensayar la hipótesis de la independencia estructural y funcional del dominio central con un péptido sintético con la secuencia de apoA-I entre los residuos 77 y 120 (AI 77-120). Para ello nos propusimos estudiar: a) la capacidad de AI 77-120 para interactuar con vesículas lipídicas e insertarse en membranas fosfolipídicas artificiales, b) la estructura secundaria y cuaternaria de AI 77120 en los estados libre y unido a membrana, y c) la actividad de este péptido comparativamente con apoA-I para desorber colesterol de membranas y catalizar su intercambio entre vesículas.

El segundo objetivo planteado fue utilizar resonancia electrónica paramagnética (EPR) para estudiar la influencia de la apoA-I y eventualmente del péptido AI 77-120 sobre la movilidad de sondas paramagnéticas localizadas a diferentes profundidades de la membrana de vesículas fosfolipídicas, y en la bicapa de HDL discoidales. Como la interacción de muchas proteínas anfitrópicas con la membrana resulta en un cambio en el ordenamiento y la movilidad de los lípidos de la membrana que depende del modo de inserción, esto podría aportar información útil sobre el modo de inserción.

El tercer objetivo del presente trabajo fue utilizar mutantes de apoA-I con un único residuo de triptofano en diferentes posiciones estratégicas del par de hélices Y central para obtener información sobre: a) la conformación de esta región de la proteína en los estados libre, unida a membrana o formando parte de HDL discoidales reconstituidas; y b) el modo y la topología de inserción de esta región de apoA-I en la membrana tratando de distinguir entre los dos modos anteriores. 


\section{CAPÍTULO III:}

MATERIALES Y MÉTODOS 


\section{Obtención de distintas formas de apo A-I}

\subsection{Purificación de apoA-I de plasma}

La apoA-I se obtuvo a partir de suero Humano (del Banco de Sangre del Instituto de Hemoterapia de la Provincia de Buenos Aires, La Plata), alternando técnicas de ultra centrifugación y cromatografía de exclusión molecular (Tricerri et al., 1998)

1.- Se descongela el plasma humano y se lleva a una densidad de 1,21 gr/ml considerando el aumento de volumen por el agregado de BrNa. Se necesitan 0,282 $\mathrm{g} / \mathrm{ml}$ de BrNa y $0.262 \mathrm{~g} / \mathrm{ml}$ de BrK para llevar a la densidad deseada.

2.- Se Ultra centrifuga a $55.000 \mathrm{rpm}$ en rotor de ángulo fijo $70 \mathrm{Ti}$ (Beckman) durante 44 hs a $10^{\circ} \mathrm{C}$.

3.- Luego de la ultra centrifugación se separa las lipoproteínas flotantes en esas condiciones. Es la capa superior de color naranja intenso (ver esquema adjunto).

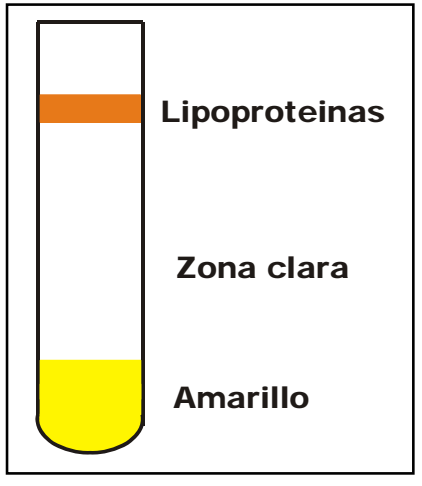

Fig.III-1 Esquema de ultracentrifucación de las lipoproteínas
4.- Luego se separan las HDL en columna abierta de Sephacryl S300 (de un metro de largo), eluyendo con Buffer Tris 10mM; CINa 0,15M; Azida 0,01\%; pH=8. Eluyen las VLDL, LDL y HDL en ese orden.

5.- Se dializan las HDL en membrana de diálisis de corte 12.000 contra EDTA $5 \mathrm{mM}$, cambiando el buffer 5 veces durante 2 días. 6.- Se deslipidiza la muestra con guanidina $\mathrm{HCl} 6 \mathrm{M}$. En base a ese calculo agregar la cantidad deseada sobre la muestra, colocar en frasco color caramelo, agitando a $37^{\circ} \mathrm{C}$ durante $3 \mathrm{hs}$, luego colocar en hielo durante 10 minutos.

7.- Se dializa contra EDTA $5 \mathrm{mM}$ pH=7,4, cambiando el buffer 5 veces durante 2 días

8.- Se lleva a densidad de $1,21 \mathrm{~g} / \mathrm{ml}$ agregando a la muestra $\mathrm{BrNa}$.

9.- Luego de llevar a densidad deseada se ultra centrifuga a $50.000 \mathrm{rpm}$ en el mismo rotor durante 24 hs a $10^{\circ} \mathrm{C}$.

10.- La capa superior flotante se separa, ya que contiene las HDL ricas en apoA-II. El resto del contenido del tubo, se colecta y dializa contra $\mathrm{CO}_{3} \mathrm{NH}_{4} 5 \mathrm{mM}$, cambiando el buffer 5 veces, durante 2 días (ver esquema). 


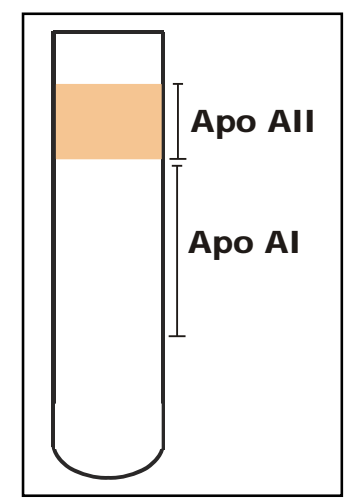

Fig.III-2 Esquema de ultracentrifucación en la separación de apoA-II de apoA-I
11.- Se liofiliza las muestras luego de dializar, y si se desea se puede interrumpir la purificación guardando las muestras a $-80^{\circ} \mathrm{C}$.

12.- Para purificar la apoA-I se disuelve el liofilizado en el buffer de elusión (Tris $10 \mathrm{mM}, 1 \% \beta$-Mercapto Etanol (BME), guanidina $\mathrm{HCl}$ $3 \mathrm{M}, \mathrm{pH} 8.0$ ), a una concentración de proteína $\sim$ de $50 \mathrm{mg} / \mathrm{ml} \mathrm{y} \mathrm{se}$ filtra por gel en columna Superdex 200 10/30 HR (Pharmacia). Se puede usar bomba (Pump-P500 presión 1.5 MPA) acoplada al detector UV y registrador.

(El BME mejora la separación de la apoA-II contaminante llevándola a su forma monomérica ya que reduce el puente disulfuro).

Se siembran 500 ul a un flujo de $0,5 \mathrm{ml} / \mathrm{min}$

13.- Se colectan las fracciones conteniendo apoA-I y se dializan contra buffer EDTA $0,01 \% \mathrm{pH}=7,5$ durante 2 días cambiando 5 veces el volumen.

14.- Luego se liofiliza, se pesa el liofilizado y se separa una parte para confirmar su pureza por gel de poliacrilamida (ver más adelante) al 12\% con Dodecil Sulfato de Sodio (SDS). El resto se rotula y guarda $\mathrm{a}-80^{\circ} \mathrm{C}$.

\subsection{Obtención de péptido central de apoA-I}

Este péptido fue sintetizado por el Servicio del Department of Biochemistry and Molecular Biology, Oklahoma State University, OK, USA, purificado (a > 95\%) por RPHPLC, y controlado por espectrometría de masa de electrospray. 


\subsection{Obtención de apoA-I con secuencia nativa (Wild type) ó mutada mediante expresión a partir de cultivos bacterianos.}

\section{i) Técnicas de biología molecular}

Obtención y amplificación de vectores para clonación: plásmidos.

Los plásmidos son secuencias de DNA de doble cadena, de origen bacteriano, que permiten la incorporación y manipulación de un gen específico, ya sea de origen procariótico o, como en nuestro caso, el cDNA de origen eucariótico a bacterias para la expresión de la proteína de elección; en este trabajo se utilizaron los plásmidos pET30, de Novagen, cuya secuencia permite la selección de bacterias subclonadas gracias a que le confiere resistencia al antibiótico Kanamicina. En el lugar de inserción del gen (polilinker) el plásmido incorpora a la secuencia del gen una cola de polihistidina directamente al inicio de la secuencia N-terminal de la proteína para su posterior purificación, esta cola de polihistina es eliminada de la secuencia de aminoácido como se explicará mas adelante (ver Fig.III-3)

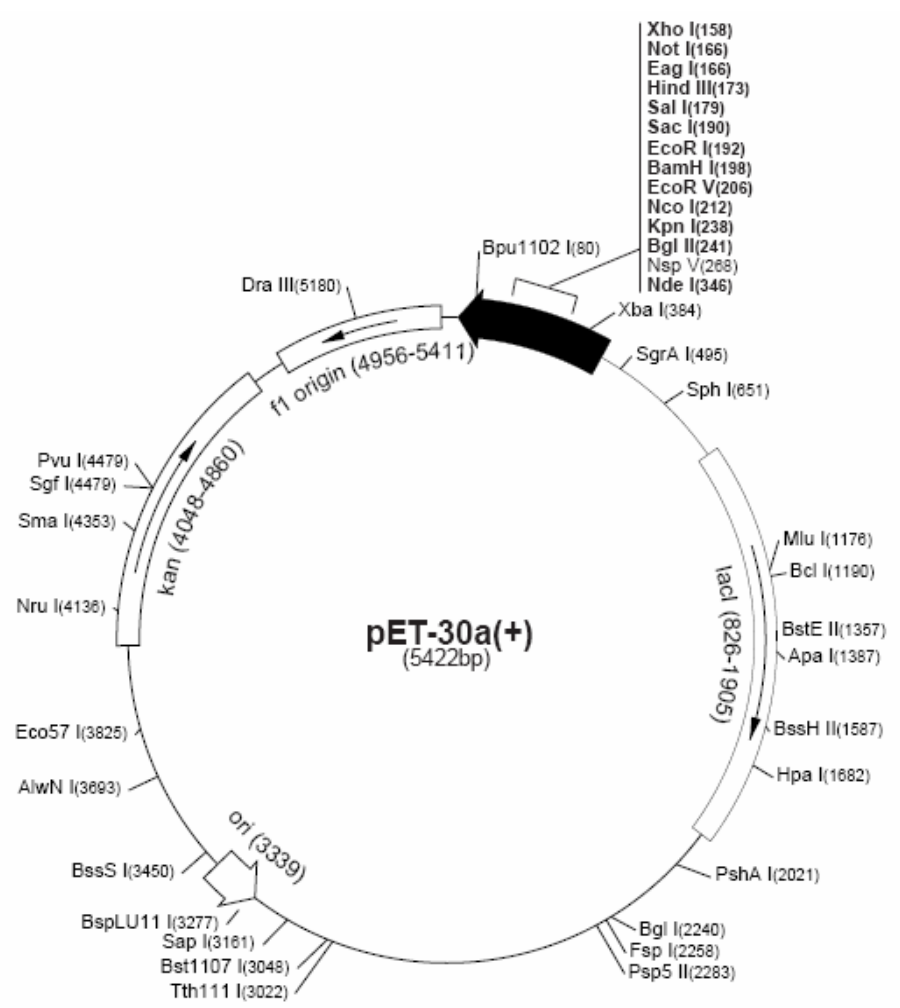




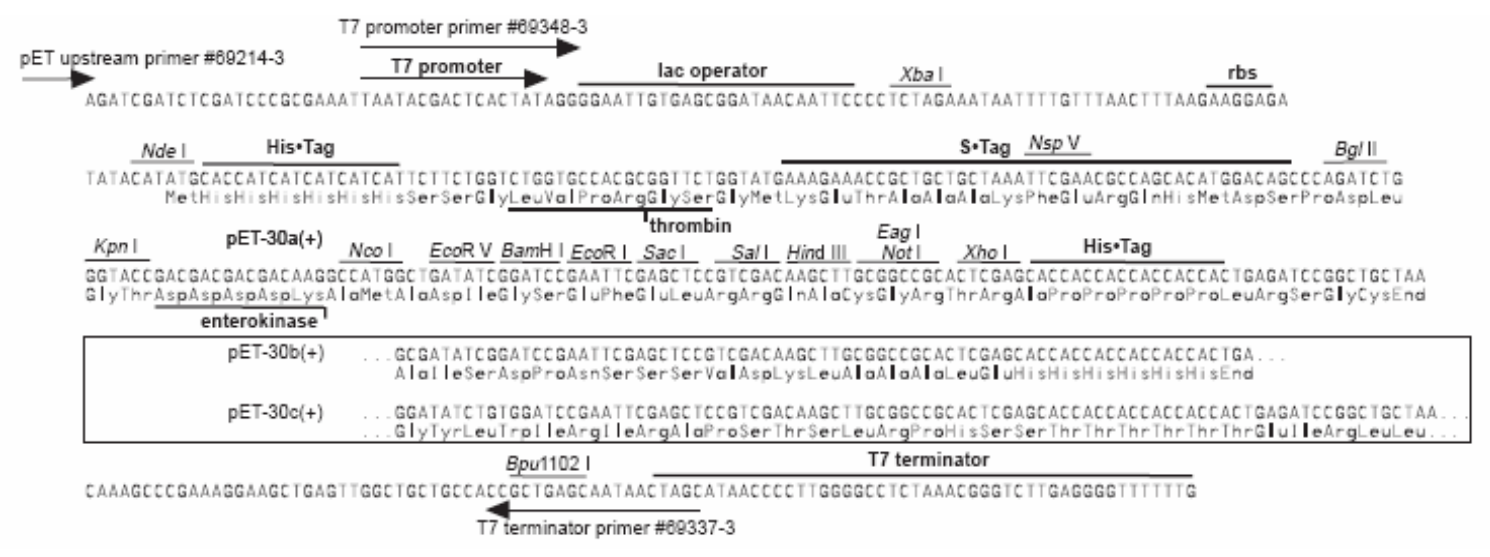

Fig III-3: esquema general del plásmido PET 30 y detalle de la secuencia de nucleótidos en el polilinker

En la figura III-3 se muestra el esquema general del plásmido en donde se observa la región del polilinker, el sitio de replicación y el gen que codifica la resistencia a kanamicina. En la parte inferior se detalla la secuencia de nucleótidos y los sitios de restricción en la región donde se inserta el gen de interés. La adición de IPTG (Isopropil Tiogaláctosido) induce al operón lac, lo que promueve la expresión del gen de la proteína insertada, junto con diferentes secuencias aminoacídicas de interés, las que facilitan su posterior purificación.

La obtención de plásmidos a partir de bacterias se realiza a pequeña escala (miniprep) en donde se obtienen microgramos de ADN plasmídico; se utilizan para tal fin dos protocolos diferentes cuyo fundamento es la lisis alcalina con Dodecil Sulfato de Sodio (SDS) para producir la liberación del plásmido de las bacterias, dejando aparte el ADN cromosómico junto con restos de pared celular. Una vez que estos restos son separados, se purifica el ADN plasmídico a partir de la solución remanente. Se utilizaron dos técnicas, una de bajo costo y casera (Sembrook and Russell, 2001), utilizada para verificar ausencia de contaminación o para obtener plásmidos para posteriores transformaciones, y la otra mediante un kit comercial de Qiagen, utilizado para obtener plásmido con una pureza considerable, adecuado para su secuenciación o posteriores manipulación en biología molecular. 


\section{ii) Tratamiento de bacterias para conferirles competencia}

En este trabajo se utilizaron huéspedes bacterianos de expansión de plásmido (JM109) y de expresión de proteínas (BL21 DE3) de Novagen, derivados de líneas de E coli; para cualquiera de los dos casos se requiere la incorporación del plásmido en las bacterias mediante el proceso de "transformación", para lo cual previamente debe manipularse las mismas para ser aptas para tal paso, o sea hacerlas "competentes".

La competencia de las bacterias se logra con un crecimiento a baja temperatura (24 ${ }^{\circ} \mathrm{C}$ ) hasta una DO de 0.6 a $630 \mathrm{~nm}$, y posteriores lavados con soluciones de $\mathrm{CaCl}_{2}-\mathrm{MgCl}_{2}$, el primer paso de este proceso altera la composición lípidica de la membrana, haciéndola mas "permeable" al plásmido, se postula que $\mathrm{CaCl}_{2}-\mathrm{MgCl}_{2}$ compleja la membrana facilitando el pegado del plásmido y posterior introducción del mismo a la bacteria (Lederberg and Cohen, 1974) una vez obtenidas se las guarda en solución con glicerol esteril al $20 \%$ a $-80{ }^{\circ} \mathrm{C}$. Este protocolo es muy sencillo y económico, pero la eficiencia de transformación es baja y pierden la competencia muy rápidamente. Otra técnica para obtener bacterias competentes es usando soluciones con RbCl, (Sembrook and Russell, 2001) obteniéndose bacterias altamente competentes, pero que pierden la competencia rápidamente y el costo de las sales de rubidio es bastante elevado.

\section{iii) Transformación}

El método por el cual se introduce plásmido dentro de bacterias se denomina transformación, y puede ser realizado por electroporación o shock térmico. El utilizado en este trabajo fue transformación por shock térmico. La técnica consiste en poner en contacto $0.2 \mathrm{ml}$ de bacterias competentes con una solución del plásmido que no supere los $20 \mu \mathrm{l}$, por el término de 30 minutos a $4{ }^{0} \mathrm{C}$, y luego se transfiere el tubo a un baño a $42{ }^{0} \mathrm{C}$ durante 90 segundos. Inmediatamente se pone el tubo en hielo y se le agrega $0.8 \mathrm{ml}$ de medio SOC. Se incuba a $37{ }^{\circ} \mathrm{C}$ durante una hora, y por último se centrífuga para obtener un precipitado de bacterias, las cuales se toman con una punta de pipeta y se distribuyen en una placa de agar al $1.5 \%$ con medio Luria- Bertani (agar -LB), mas el antibiótico adecuado (en nuestro caso Kanamicina $30 \mu \mathrm{g} / \mathrm{ml}$ ). Se deja la placa a temperatura ambiente por una hora, para luego incubarla por 24 horas a $37{ }^{0} \mathrm{C}$ para que desarrollen las bacterias transformadas, que van a ser aquellas que poseen resistencia al antibiótico por tener el plásmido. Luego se toman una a una las colonias y se las crece en medio LB líquido con 
antibiótico; la mitad de medio se separa para comprobación del proceso (purificación del plásmido y análisis de secuencia ó expresión), y el resto se guarda en glicerol $20 \%$ a $-80^{\circ} \mathrm{C}$ para su conservación.

Medio de cultivo Luria-Bertani (LB): 10 gr de triptona bacteriológica

5 gr de Extracto de levadura

10 gr de $\mathrm{NaCl}$

Se lleva a $\mathrm{pH}$ de 7.4 y a volumen de un litro, para luego esterilizar por 15 minutios a $120^{\circ} \mathrm{C}$.

Medio SOC: 20 gr de triptona bacteriológica

5 gr de Extracto de levadura

5 gr de $\mathrm{NaCl}$

Glucosa $20 \mathrm{mM}$.

Se lleva a volumen de un litro y se esteriliza por filtración

\section{iv) Construcción de los mutantes de apoA-I}

La amplificación de cadenas de ácidos nucleicos ha sido posible gracias al acceso de oligonucleotidos de origen sintético y a la obtención de polimerasas, este hecho ha logrado la clonación, y modificación de genes in vitro y en forma rápida, gracias a la denominada Reacción en Cadena de la Polimerasa (PCR), la que permite obtener, de una región determinada del genoma, millones de copias, siempre que una parte de su secuencia sea conocida. La técnica consiste básicamente en diseñar en una primera etapa dos oligonucleotidos iniciadores o "primers" a partir de la secuencia conocida, cada uno complementario a una de las hebras de la doble hélice y en extremos opuestos. El éxito de la técnica se logra gracias al uso de una DNA polimerasa aislada de una bacteria termófila que es estable a muy altas temperaturas, de forma tal que no se desnaturaliza al aumentar la temperatura en sucesivos ciclos. Cuando se calienta la doble hebra y posteriormente se enfría en presencia de exceso de los "primers", se logra que estos oligonucleótidos se hibridicen o "peguen" con las secuencias complementarias de DNA genómico, y luego que, en presencia de los cuatro desoxinucleótidos y de la DNA polimerasa, se elonge la secuencia flanqueada por los primers. Cuando se repite el procedimiento los fragmentos recién sintetizados sirven de moldes, y en pocos ciclos el producto que predomina es una secuencia única de DNA cuya longitud corresponde a la distancia de nucleótidos que hay 
entre los primers (ver Fig. III-4), cada ciclo toma por lo general unos 5 minutos, por lo que el procedimiento completo lleva unas pocas horas. El esquema general de la técnica se muestra en la Fig. III-4 (Sembrook and Russell, 2001).
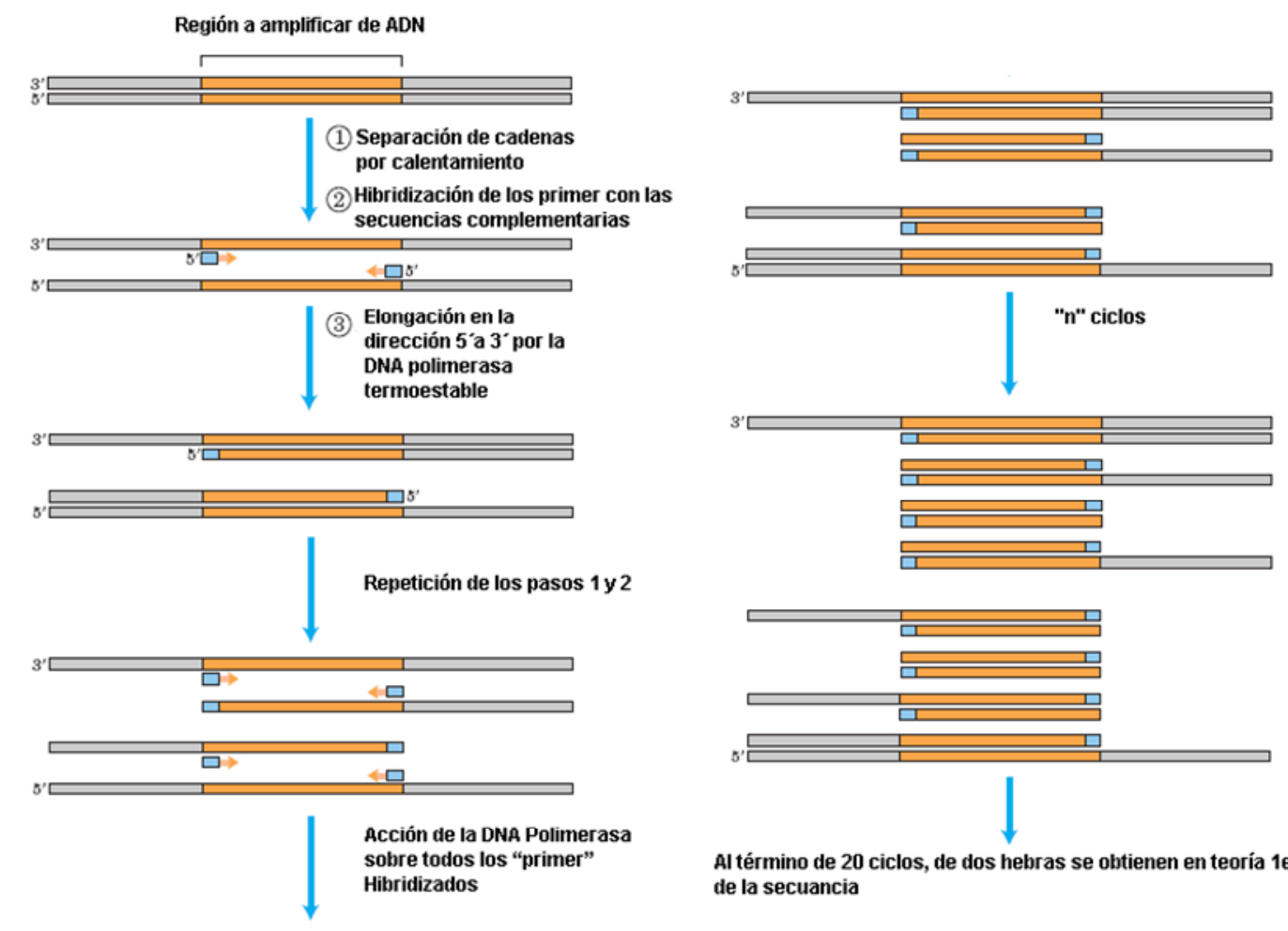

Al término de 20 ciclos, de dos hebras se obtienen en teoría 1exp 6 copias de la secuancia

Fig.III-4 . Esquema de amplificación de una secuencia de ADN por medio de la Reacción en Cadena de la Polimerasa (PCR).

Con una modificación de esta técnica se logra introducir un mutación, ya sea eliminando, agregando o cambiando los codones que codifican para aminoácidos, además de la amplificación de una región o secuencia de ADN genómico.

En este trabajo, incorporamos mutaciones puntuales en sobre la secuencia de apoAI inserta en vector plasmídico, utilizando en la reacción de PCR oligonucleótidos o primers complementarios que poseen el cambio requerido (ver Fig. III-5).

Uno de los objetivos propuestos fue la construcción de una serie de mutantes de apoA-I conteniendo un único residuo de Triptofano en diferentes posiciones de su región central, a fin de estudiar la conformación de esta región y su mecanismo de inserción en membranas. 

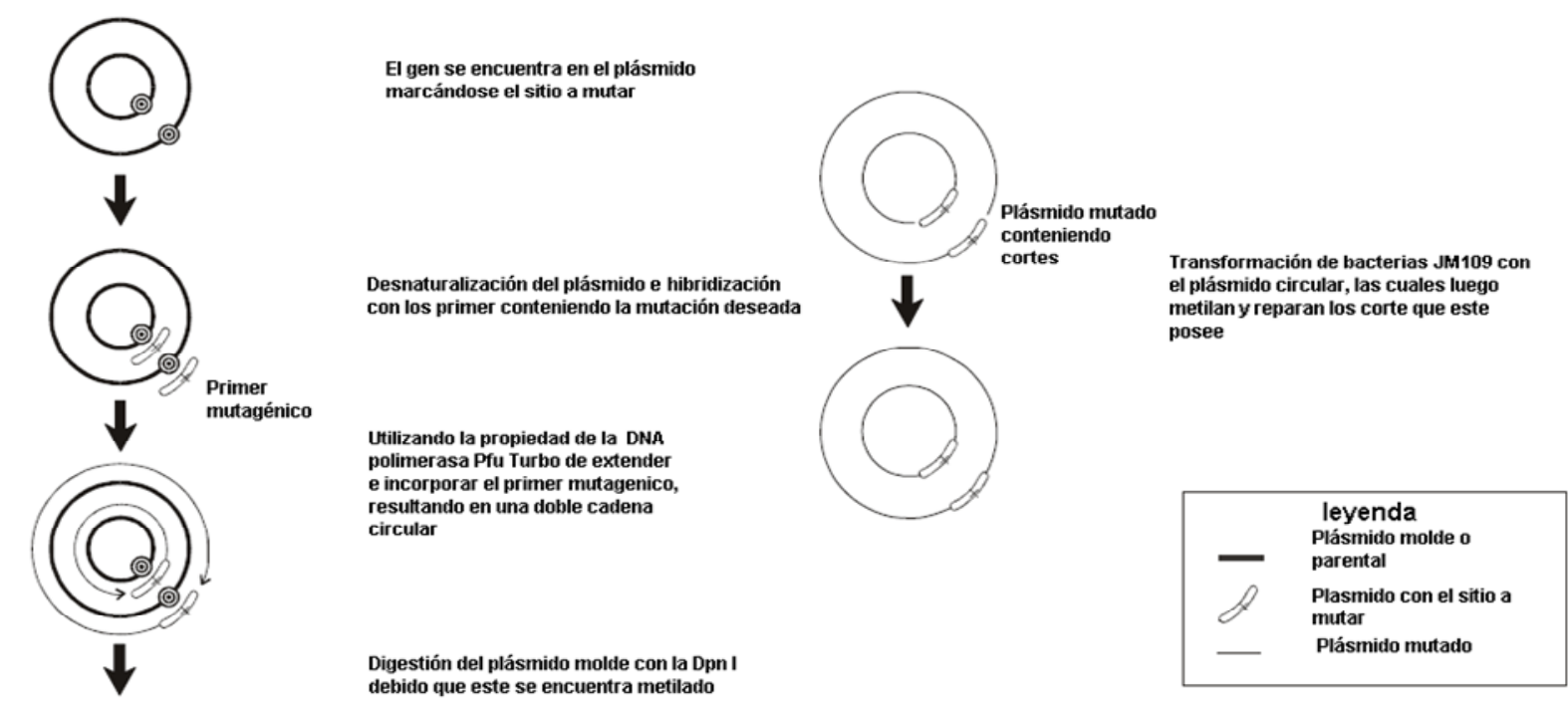

Figura. III-5:_esquema de PCR modificada en donde se logra la mutación de un gen en un sitio específico

Se realizó la construcción de estos mutantes por mutagénesis sitio dirigida usando el kit comercial "Quick-Change" de Stratagen. En este método se utiliza una ADN polimerasa (PfuTurbo) de muy baja tasa de error, lo que permite realizar la reacción de PCR sobre el plásmido completo. El plásmido pET 30 conteniendo el inserto del cDNA de un mutante libre de residuos Trp (W@Ø) fue utilizado como plantilla para lograr las mutantes finales con una única ronda de mutagénesis. Esta construcción molde fue donada por el Dr WS Davidson de la Universidad de Cincinatti, OH, USA. Seis juegos de oligonucleótidos iniciadores complementarios (cumpliendo los requerimientos de temperatura de fusión recomendados por los fabricantes del kit) fueron diseñados para introducir un codon para triptofano individualmente en cada una de las seis posiciones ocupadas por un residuo hidrofóbico en la región central de apoA-I (W@90, W@93, W@97,W@101,W@104 y W@108), y fueron sintetizados en el Department of Biochemistry and Molecular Biology, Oklahoma State University, Stillwater, OK, USA. Estos mutantes, al igual que la Wild Type, poseen una secuencia de pre-pro apoA-I junto con una secuencia de poli Histidina en la región N- Terminal; esta secuencia pre-pro (5 amino ácidos) existe en la construcción, ya que mejora notablemente los niveles de expresión en bacterias sin alterar la funciones de la proteína (McGuire et al., 1996) Para eliminar esta secuencia junto con la de poli Histidina se le ha insertado un sitio de 
reconocimiento de corte para la enzima igasa, cuya especificidad de corte es mucho mejor que la de la enteroquinasa, presente en la forma Wild Type.

Una vez realizadas las rondas de PCR, en presencia de las secuencias iniciadoras complementarias mencionadas, se digiere el producto con enzima de restricción DpnI que elimina el plásmido molde ó "template" y el producto de la digestión se transforma en bacterias competentes JM109, con el objetivo de expandir el plásmido para posterior extracción por lisis alcalina y así verificar por secuenciación la introducción de la mutación deseada. Las muestras se envían a secuenciar mediante métodos estándares y se analizan con ayuda de programas clásicos (Gene-runner). Una vez verificada la secuencia, se transforma células (BL21 (DE3)) con el plásmido conteniendo el inserto deseado para llevar a cabo la expresión de la proteína.

\section{v) Expresión y purificación}

Una vez que los plásmidos fueron introducidos en las bacterias BL21 y verificado que las bacterias crecidas en las placas no eran contaminaciones se buscaron las condiciones de expresión y purificación. Las de mejor resultado consistieron en hacer un plaqueo en medio LB/agar con antibiótico (kanamicina), luego crecer una colonia en $5 \mathrm{ml}$ de medio líquido toda la noche $(\mathrm{ON})$, para después inocular $1 \mathrm{ml}$ de estas bacterias en un erlenmeyer con $500 \mathrm{ml}$ de medio líquido. El crecimiento se continúa hasta una densidad óptica (DO) de 0.6 a $650 \mathrm{~nm}$ para inducir a continuación la expresión con $0.4 \mu \mathrm{M}$ IPTG. Se deja induciendo por el término de dos horas, se centrifuga y colecta todas las bacterias, y al pelet de bacterias se las lisa incubando durante 4 hs con solución de guanidina $\mathrm{HCl} 3$ M, ya que una gran cantidad de proteína expresada se deposita en los cuerpos de inclusión. Se centrifuga para eliminar membranas y restos celulares, y se dializa contra 1000 volúmenes de buffer Fosfato de Potasio 50mM, NaCl 500mM, pH 7.4 con tres cambios del buffer. Al término de la diálisis se vuelve a centrifugar para eliminar todas las proteínas insolubles en medio acuoso. El sobrenadante, si bien está muy enriquecido en la proteína recombinante, tiene una proporción considerable de contaminantes, que se eliminan por elusión a través de columnas de afinidad de metales inmovilizados (IMAC). Las proteínas mutantes quedan adsorbidas a la matriz de la columna por afinidad con la cola de poli Histidina, y, posteriormente se eluyen por competencia con buffer con Imidazol. 


\section{vi) Eliminación de la secuencia de fusión mediante corte con enzima proteolítica}

El vector pET30, como se mencionó, presenta directamente adyacente al sitio de clonado de la proteína de interés, una secuencia que codifica para un péptido con un dominio polihistidina para facilitar la purificación. El clon de la apoA-I inserto corresponde a la pre-pro apoA-I ya que de esta forma se puede obtener gran cantidad de proteína. Si bien se ha demostrado que el pre-pro péptido adicional no cambia las propiedades de apoA-I, posee un residuo de Trp que interfiere con las mediciones a realizar. Ya que las proteasas (como enteroquinasa) ampliamente usadas con el propósito de clivar proteínas de fusión producen proteólisis inespecífica de apoA-I, el inserto contiene un sitio de reconocimiento para la enzima proteolítica IGASA, diseñado de manera tal de eliminar simultáneamente el pro-péptido. La reacción de proteólisis con esta enzima es bastante específica, pero muy dependiente de las condiciones usadas, siendo las de mejor resultado una incubación por 24 horas a $32{ }^{0} \mathrm{C}$ en buffer tris $20 \mathrm{mM}$, EDTA 5 mM, pH 7,8; la reacción se termina con un agente inhibidor de proteasas, el PMSF (Phenyl Methyl Sulfonyl Fluoride). 


\section{Técnicas electroforéticas}

Cuando una molécula cargada es sometida a un campo eléctrico, ésta migrará a una velocidad que dependerá del tamaño, carga neta, forma y viscosidad del medio en el cual se mueve (Laemmli, 1970). Por lo tanto establecidas las condiciones de $\mathrm{pH}$ y fuerza iónica, cada molécula migrará a una única posición dentro del campo eléctrico. En la separación de moléculas de ácidos nucleicos el soporte utilizado es un gel de agarosa, mientras que para la separación de proteínas el soporte utilizado es una matriz polimerizada de acrilamida y N,N'-metil-bis-(acrilamida) (PAGE) en buffer glicina usando como iniciador tetrametilenamida (TEMED) y como catalizador persulfato de amonio. Este tipo de geles es mecánicamente fuerte, termoestable y químicamente inerte. El efecto tamiz aumenta la resolución y puede graduarse fácilmente el tamaño del poro, modificando las cantidades de agente soporte.

\subsection{Geles de agarosa:}

La electroforesis de geles de agarosa se utilizó en la separación de fragmento de DNA en base a su peso molecular y a su grado de empaquetamiento; los fragmentos más pequeños migran mas rápido que los de mayor tamaño, y la distancia recorrida en el gel es inversamente proporcional al logaritmo del peso molecular. De esta manera el tamaño puede ser determinado por calibración del gel con estándares de peso molecular conocido y comparando las distancias que migran los fragmento desconocidos.

Preparación del gel: se realizaron geles horizontales, con solución de agarosa al $0.8 \%$ en buffer TBE. Dado que la agarosa se disuelve en caliente, se prepara primero la suspensión de la misma y se la calienta en horno de microondas agitando cada $15 \mathrm{seg}$ hasta que no se observan mas "grumos" de agarosa. Una vez logrado una solución homogénea se la deja enfriar hasta unos $60{ }^{\circ} \mathrm{C}$ y se la vuelca en la cama horizontal del gel, colocando el peine para formar los pocillos de siembra y dejando enfriar hasta que gelifique. Una vez logrado esto último se coloca el gel en la cuba electroforética y se la cubre con buffer TBE.

Siembra de muestras: se siembran 5 ul de las mismas (lo ideal es que tenga unos $20 \mathrm{ng}$ de ADN por banda para evitar distorsiones) con 1 ul de "loading buffer"y se corre a 100 vol hasta que el frente haya recorrido aproximadamente el $80 \%$ del tamaño del gel. Para observar la presencia de ácidos nucleicos se incuba el gel por 30 minutos en solución de 
bromuro de Etidio al 10\% en TBE, para luego observar las bandas por medio de luz UV de un trans iluminador.

Las soluciones utilizadas fueron:

- Solución de TBE (Tris 50 mM- Boro 50 mM- EDTA 1mM) pH 8

- Loading Buffer (6X: NaOH 300mM, 6 mM EDTA, $18 \%$ p/v ficoll, $0.15 \%$ p/v verde de Bromo cresol, y $0.25 \%$ p/v Xileno Cianol)

\subsection{Geles de Poliacrilamida:}

Los geles PAGE fueron utilizados para la determinación de pureza y pesos moleculares de proteínas y/o complejos lipoproteicos; para esto se utilizaron básicamente dos tipos de procedimientos: uno en condiciones nativas y con gradiente de poliacrilamida, en donde cada proteína migra dependiendo de la relación carga/masa hasta que el tamaño del poro impide su migración; la otra variante es en condiciones desnaturalizantes con Dodecil Sulfato de Sodio (SDS) (SDS-PAGE), en donde la matriz tiene una composición constante, pero todo el sistema posee un detergente como agente desnaturalizante; éste desestabiliza toda interacción no covalente de la proteínas combinándose en una relación estequiométrica (por cada 2 aminoácido 1 de SDS), independizando la carga neta que tendría la proteína a ese $\mathrm{pH}$, y por lo tanto siendo la migración dependiente solamente del tamaño de la molécula.

Los protocolos de estos sistemas son:

\section{- Sistema de gel nativo para proteínas (PAGE):}

El método utilizado es el de Laemmli (Laemmli, 1970). Consiste en un sistema vertical discontinuo que posee dos geles contiguos, pero distintos: el gel separador por debajo y el gel de siembra por encima, ambos distintos en fuerza iónica, $\mathrm{pH}$ y tamaño de poro. Esta discontinuidad sirve para concentrar grande volúmenes de muestra en el gel de siembra, resultando en una mejor resolución final. El gel de siembra se preparó con una concentración final de 4\% p/v de acrilamida, la cual se polimeriza resultando el tamaño de poro no limitante. El gel separador implica un gradiente lineal de concentración que va de $4 \%$ a $25 \% \mathrm{p} / \mathrm{v}$ en acrilamida. Las proteínas se detectaron coloreando con solución de Coomassie, ó tinción de plata en caso de que la cantidad de proteína sea inferior a la detectada con la primer técnica. 


\section{- Sistema de gel desnaturalizante (SDS-PAGE):}

Posee como el anterior dos geles contiguos, uno separador y otro resolutivo diferenciándose en las condiciones de $\mathrm{pH}$, fuerza iónica y tamaño de poro, el primero posee la mismas condiciones que el nativo, excepto que posee el agente desnaturalizante SDS a una concentración de $0.1 \% \mathrm{p} / \mathrm{v}$. El gel resolutivo consiste en un gel continuo de concentración constante, lo cual indica que el tamaño del poro es igual a lo largo del gel, este tamaño se logra variando la concentración final de acrilamida, y como el gel de siembra, posee SDS en una concentración de $0.1 \%$. La muestra es tratada con buffer muestra que posee SDS $(0.1 \%)$ y se la hierve por el término de 3 minutos, para luego correr el gel a 140 voltios. Hay que tener en cuenta que en este tipo de "corridas" la proteína no llega hasta el poro límite. La tinción es similar que en caso anterior.

Este tipo de sistemas es útil para resolver muestras de proteínas desde $15 \mathrm{kD} \mathrm{y}$ como hemos trabajado con péptidos de tamaño menor, utilizamos un sistema que resuelve mejor mezclas de péptidos pequeños denominados geles de Tricina (Schägger and Jagow, 1987) que, aparte del gel de siembra, posee dos geles contiguos de concentraciones diferentes, denominándose el primero espaciador (spacer) y el siguiente resolutivo (resolving), todos preparados en las mismas condiciones de $\mathrm{pH}$ y fuerza iónica; en este caso el buffer catódico posee tricina pero no el anódico.

Las soluciones utilizadas son:

\section{Geles PAGE y SDS- PAGE}

_Acrilamida $(40 \% \mathrm{p} / \mathrm{v}) /$ Bis Acrilamida $(0.8 \%)$

_Buffer de gel siembra: Tris-HCl $0.125 \mathrm{M} \mathrm{pH} 6.8$

_Buffer de gel separador: Tris-HCl $0.375 \mathrm{M} \mathrm{pH} 8.8$

Iniciador: Persulfato de amonio $(10 \mathrm{mg} / 100 \mu \mathrm{l})$

Catalizador: TEMED

Buffer de desarrollo: Tris-Glicina 0.025 M- Tris 0.192 M Glicina. PH 8.3.

Colorante: Coomassie Blue g-250, $0.1 \%$, en ácido acético 10\%, metanol 40\%

Buffer muestra: Tris $0.062 \mathrm{M}$, glicerol 10\%, azul de bromo fenol $(0.05 \mathrm{mg} / \mathrm{ml})$, $\mathrm{pH} 6.8$

Los SDS-PAGE poseen todas las soluciones SDS de concentración 0.1\%

\section{Geles Tricina (con SDS):}

_ Acrilamida (40\%p/v)/Bis Acrilamida (1.5\%)

_Buffer de gel: Tris $0.3 \mathrm{M}, \mathrm{pH} 8.45$, SDS $0.3 \%$

_Buffer Anódico: Tris 0.2M, pH 8.9, SDS 0.3\% 
_Buffer Catódico: Tris 0.1M, Tricina $0.1 \mathrm{M} \mathrm{pH \quad} \mathrm{8.25,} \mathrm{SDS} \mathrm{0.3 \%}$

_Iniciador: Persulfato de amonio $(10 \mathrm{mg} / 100 \mu \mathrm{l})$

Catalizador: TEMED

_Buffer de desarrollo: Tris-Glicina 0.025 M- Tris 0.192 M Glicina. pH 8.3.

_Colorante: Coomassie Blue g-250, 0.1 \%, en ácido acético 10\%, metanol 40\%

_Buffer muestra: tris0.062M, glicerol 10\%, azul de bromo fenol $(0.05 \mathrm{mg} / \mathrm{ml}), \mathrm{pH} 6.8$

\section{Determinación de concentración de proteína}

La determinación de concentración de proteínas fue realizada en todos los casos midiendo la absorbancia a $280 \mathrm{~nm}$, después de determinar el espectro de absorción de cada proteína desde 200 a $400 \mathrm{~nm}$ Este método fue elegido ya que al conocerse la secuencia de la apoA-I y de sus mutantes, se puede calcular su coeficiente de extinción dado por diversos programas accesibles por internet (www.expasy.org). Este tipo de programas calcula el coeficiente partir de la contribución individual de los aminoácidos (Trp, Tyr, Phe y Cys) de la secuencia suponiendo que se comportarán igual que en la proteína entera; se estima que el error cometido es menor al 5 \% (Gill and von Hippel, 1989). Otras de las ventajas de este método es que no se pierde muestra y del espectro se puede observar la calidad de la misma. Este método se ha comparado con los convencionales Lowry y/o Bradford, no observándose diferencia significativa, más allá de las limitaciones de estos últimos. 


\section{Técnicas Espectroscópicas}

\subsection{Resonancia Electrónica Paramagnética (EPR)}

La mayor cantidad de moléculas o átomos poseen todos sus electrones apareados a los que se denominan diamagnéticos, sin embargo en los sistemas biológicos existen dos clases de moléculas que poseen electrones desapareados, denominados paramagnéticas: radicales libres, y metales de transición. La característica básica de la Resonancia Electrónica Paramagnética es su capacidad de detectar electrones desapareados, siendo la propiedad esencial detectada el momento magnético asociado con el spin del electrón.

Si se coloca una sustancia en un campo magnético de intensidad $\mathrm{H}$, el campo inducido $\mathrm{B}$ dentro de la misma, esta dado por

$\mathrm{B}=\mathrm{H}+4 \pi \mathrm{M}=\mu \mathrm{H}$

siendo M la magnetización, o momento dipolar magnético por $\mathrm{u}$. de volumen, y $\mu$ la permeabilidad. Para materiales no ferromagnéticos, se cumple que $\mathrm{M}=\chi \mathrm{H}$, donde $\chi$ es la susceptibilidad por $u$. de volumen.

Si se divide la ecuación anterior por $\mathrm{H}$, entonces tenemos $\mu=1+4 \pi \chi$, Si la susceptibilidad $\chi$ no depende del campo aplicado y además es positiva, la sustancia es paramagnética y concentra las líneas de fuerza dentro de la sustancia, si es negativa, la sustancia es diamagnética y dispersa las líneas de fuerza.

Para cada electrón desapareado, el espín es $\mathrm{S}=1$ / 2 y su energía sin campo eléctrico es Eo, cuando se aplica un campo los espines de los electrones se acomodan paralelos o antiparalelos al campo aplicado, siendo su energía

$\mathrm{E}=\mathrm{Eo}+\mathrm{ms}^{*} \mathrm{~g} * \mu \mathrm{b} * \mathrm{~B}(2)$

(interacción Zeeman) en donde ms es la proyección del espín del electrón en la dirección del campo y toma los valores $+1 / 2$ y $-1 / 2$, g (factor espectroscópico) y $\mu \mathrm{b}$ (magnetón de Bohr queconvierte las unidades de momento angular en momento magnético) son constantes, y Bes el campo que "ve" el electrón (McMillan, 1975).

La representación esquemática de los niveles energéticos que pueda adquirir cada electrón en función del campo H se muestra en la figura III-6 a continuación. 


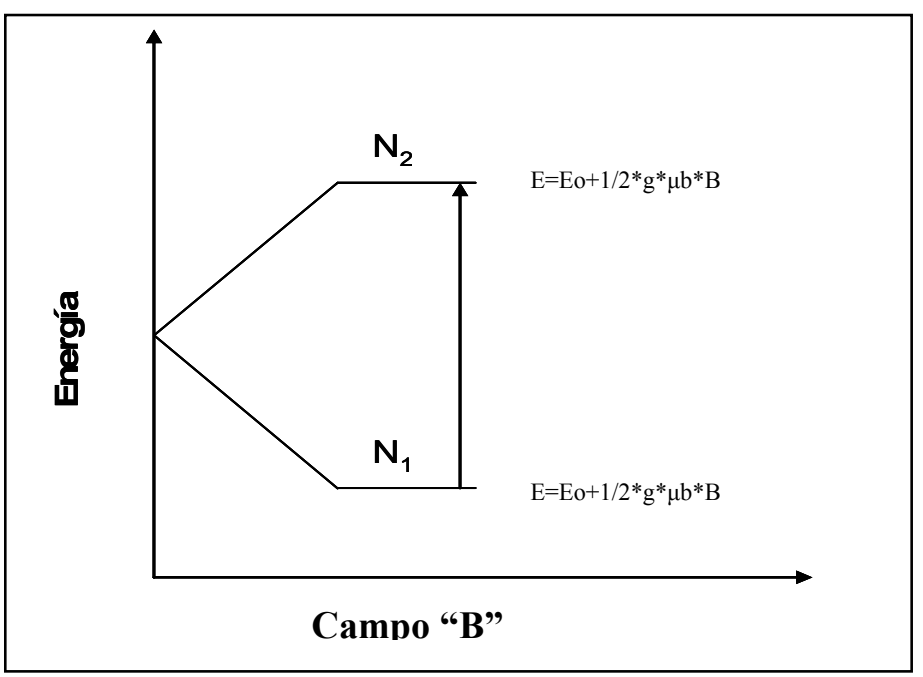

Fig.III-6. División de niveles de energía en un campo magnético

La diferencia de energía que existe entre los dos niveles está dada por $\Delta \mathrm{E}=\mathrm{g} * \mu_{\mathrm{b}} * \mathrm{~B}(4)$

$\mathrm{Si}$ conjuntamente con el campo magnético externo se aplica una radiación electromagnética, esta será absorbida y se inducirá la transición del nivel inferior al superior, y se producirá la condición de resonancia cuando el cuanto radiación de valor $\mathrm{h} * \mathrm{v}$ (donde h y $v$ son la cte de Plank y la frecuencia de la radiación) sea igual a: $\mathrm{h} * v=\mathrm{g}^{*} \mu_{\mathrm{b}} * \mathrm{H}$ (5) (en las ecuaciones puede aparecer indistintamente $\mathrm{H}$ o $\mathrm{B}$, ya que estrictamente es B es el valor de campo que "ve" el electrón).

Así los espectros de EPR pueden ser determinados igualmente manteniendo la intensidad del campo magnético aplicado $\mathrm{H}$ y variando la frecuencia de radiación $v$; o la inversa, manteniendo fija la frecuencia de radiación $v$ y variando el campo B. Ya que los generadores de microondas (válvulas o diodos Gunn) solo pueden "barrer" un estrecho margen de frecuencias (8-10 GHZ), normalmente se utiliza la opción de "Barrer" el campo magnético. De esta última manera es como funciona la mayoría de espectrómetros de EPR. De acuerdo con la última ecuación (5) la condiciónde resonancia se podrá cumplir con cualquier radiación electromagnética, simplemente aplicando la adecuada intensidad del campo. Sin embargo la intensidad de absorción depende de la diferencia de población entre los niveles, por lo que la distribución de población está dada por la diferencia de energía entre los niveles a una determinada temperatura:

$$
\mathrm{N}_{2} / \mathrm{N}_{1}=\mathrm{e}^{-\mathrm{h}^{*} \mathrm{v} / \mathrm{kT}}(6) \text {. }
$$

Así para aumentar la sensibilidad del método se trabaja a alta intensidad de campo (como ser a $0.3-1.2 \mathrm{~T}$ ) y de ser posible, a baja temperatura. En general los 
espectrómetros trabajan en la región

de microondas (como ser entre 9* 109-3.6*1010 HZ, correspondiente a longitudes de onda que van desde 3.0 a $0.75 \mathrm{~cm}$ ). La señal detectada en los espectros de EPR se analiza como la derivada del espectro de absorción.

La señal detectada en los espectros de EPR se analiza como la derivada del espectro de absorción. Muchos tipos de interacciones pueden ocurrir en un sistema paramagnético, dependiendo de la naturaleza del sistema y del medio en que se encuentra. Las interacciones pueden ser intra- ó intermoleculares, estas últimas pueden ser evitadas usando muestras en que la sustancia paramagnética está lo suficientemente diluida en una sustancia diamagnética. Para un único electrón desapareado, una interacción de Zeeman pura producirá únicamente dos niveles de energía, y el espectro de EPR consistirá en una sola línea de absorción. Además de la interacción de Zeeman, puede ocurrir interacción entre el electrón y el momento magnético del núcleo (acoplamiento hiperfino), y en caso de moléculas con más de un electrón desapareado, pueden ocurrir interacciones entre sus spines. En ambos casos se puede producir una separación en varias líneas de absorción (splitting).Solamente se va a discutir la interacción entre los electrones desapareados con su núcleo, ya que los marcadores de spines utilizados, poseen solamente un electrón desapareado.

La interacción hiperfina surge de la interacción entre el electrón desapareado con el momento magnético del núcleo del algún átomo con el cual su orbita está asociada cuando este electrón siente un campo magnético adicional debido a las $2 \mathrm{I}+1$ orientaciones posibles que puede asumir el momento magnético del nucleo. Para un electrón desapareado interactuando con un núcleo de spin I, se producirá la separación de cada nivel Zeeman en $2 \mathrm{I}+1$ diferentes subniveles.

Si por ejemplo el espín del electrón es $1 / 2$ y el del núcleo es $1 / 2$, el electrón va a experimentar un efecto conjunto con el campo aplicado y con el inducido por el núcleo, y la energía de los electrones sería:

$\mathrm{E}=\mathrm{Eo}+\mathrm{m}_{\mathrm{s}}^{*} \mathrm{~g} * \mu_{\mathrm{b}} * \mathrm{~B}+\mathrm{m}_{\mathrm{s}} * \mathrm{~m}_{\mathrm{I}} * \mathrm{~A}(7)$

en donde $\mathrm{m}_{\mathrm{s}}$ es la componente $\mathrm{z}$ del electrón, $\mathrm{y} \mathrm{m}_{\mathrm{I}}$ la componente $\mathrm{z}$ del del núcleo. Por ejemplo, para un electrón que interactúa con un núcleo de $\mathrm{I}=1 / 2$, el espectro en este caso será de dos líneas de igual intensidad, y la separación entre las líneas será proporcional a la interacción núcleo-electrón que se denomina constante de acoplamiento hiperfino (“A” en la ecuación 7) y no depende del campo aplicado siempre que éste sea lo suficientemente 
fuerte para cuantificar por separado los momentos magnéticos del electrón $(\mathrm{S})$ y del núcleo (I); esto no se cumple cuando los spines nucleares y electrónicos se acoplan para dar un solo número cuántico "F"

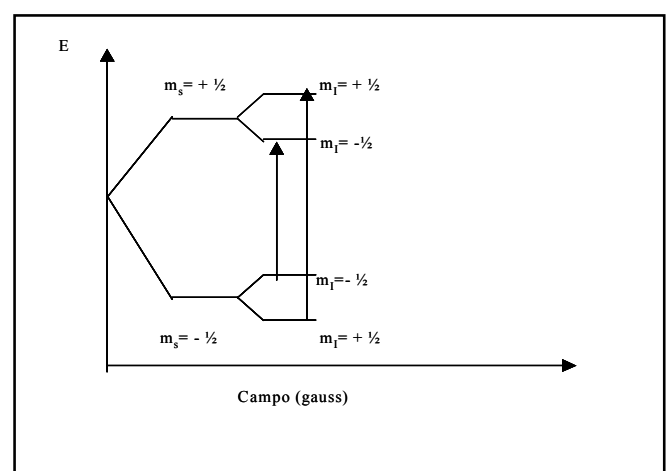

Fig.III-7: esquema en como se dividen los niveles Zeeman por interacción del electrón desapareado con el momento magnético nuclear $\mathrm{I}=1 / 2$

Los átomos que constituyen los sistemas biológicos con spines nucleares no nulos son el $\mathrm{H}$ $(\mathrm{I}=1 / 2), \mathrm{N}(\mathrm{I}=1), \mathrm{F}(\mathrm{I}=1 / 2)$, el $\mathrm{C}$ y el $\mathrm{O}$ en sus isótopos abundante no poseen, pero si lo poseen los isótopos ${ }^{13} \mathrm{C}(\mathrm{I}=1 / 2)$ y ${ }^{17} \mathrm{O}(\mathrm{I}=5 / 2)$

Las transiciones posibles son $\Delta \mathrm{m}_{\mathrm{s}}=1 \Delta \mathrm{m}_{\mathrm{I}}=0$

La medición del espectro nos permite obtener información sobre el medio ambiente que rodea al electrón desapareado. Existen dos tipos de interacciones que pueden contribuir a la forma del espectro: Interacciones "spin-Lattice", y las interacciones "spin-spin". Las primeras representan las interacciones que tienen lugar entre el electrón y el medio ambiente que lo rodea, ya sea de la red cristalina o del resto de la molécula en que se encuentra. Estas interacciones hacen que la energía captada por el electrón se relaje en el medio ó sistema molecular y por lo tanto el proceso es continuo. Este proceso acorta los tiempos de vida de los niveles excitados produciendo (por el principio de incertidumbre) un ensanchamiento de líneas espectrales. El tiempo de correlación longitudinal ó de spinlattice ( $\mathrm{Tl}$ ) es el tiempo que lleva a perder el electrón 1/e de la energía absorbida y está relacionado con la inversa del ancho de banda. Cuando existe baja intensidad de radiación (para evitar saturación del sistema), El otro mecanismo, la interacción spin-spin, que modula la energía sin causar transiciones, mantiene la energía de Zeeman constante en contraste con la interacción spin-lattice y está caracterizado por el tiempo de correlación transversal (T2), produciendo una curva de absorción Lorentziana, cuyo ancho es directamente proporcional con la distancia de pico apico de la curva derivada. Los dos 
mecanismos producen una de curva de absorción Lorentziana, que esta relacionada directamente proporcional con la distancia de pico a pico de la curva derivada.

Las interacciones spin-spin están relacionadas con todos los mecanismos por los cuales los electrones pueden intercambiar energía entre ellos, una aplicación de la medida de esta interacción es poder medir la difusión transversal y no serán discutidos en este trabajo.

\section{Efecto de movilidad en los espectros de EPR}

Los espectros de EPR para un mismo marcador son distintos si éste se encuentra en una estructura cristalina o si se encuentra en solución. La separación hiperfina consiste básicamente en dos tipos de interacciones. La primera puede asemejarse a la clásica interacción dipolo-dipolo entre los momentos magnéticos del spin electrónico y el nuclear. Esta interacción tiene una variación angular dada por $3 \cos ^{2} \theta-1$, que tomará los valores de 2 a -1 cuando $\theta$ tome valores entre 0 y $\Pi / 2$. El segundo tipo de interacción es la de contacto o de Fermi (Berliner, 2002), (Ingram, 1969) este contacto es independiente del ángulo entre el campo magnético aplicado y la particular orientación del marcador. La interacción dipolar magnética entre los electrones desapareados causa un corrimiento del campo que siente cada electrón, causando una dispersión de los campos de resonancia.. Si se tiene una estructura cristalina con las moléculas paramagnéticas perfectamente orientadas, tanto el valor de g (factor descrito anteriormente) como las interacciones hiperfinas dependerán de la orientación relativa del campo aplicado y la del eje del campo eléctrico interno de la estructura cristalina o de cualquier determinante de estructura. Entonces, si se rota el cristal en el campo magnético se obtendrán distintas intensidades de campo de resonancia como así también distintas separaciones hiperfinas. Si por lo contrario las moléculas están orientadas al azar en un sólido o en un medio de muy alta viscosidad, el espectro será la suma de los espectros individuales para cada orientación y habrá así un gran ensanchamiento de la línea de absorción.

En el caso de soluciones en estado líquido, las moléculas están orientadas al azar tanto respecto al campo como a las otras moléculas. Todas las moléculas se están moviendo rápidamente, de manera tal que las moléculas cercanas a un electrón desapareado cambian rápidamente de posición en un tiempo mucho más corto que el requerido en la transición del spin electrónico. Esto hace que la contribución del entorno al campo magnético del electrón desapareado sea un promedio de todas las interacciones 
producidas por todas las moléculas en el transcurso de la transición. Un promedio de $3 \cos ^{2} \theta-1$ sobre todos los ángulos será igual a cero. Por lo tanto si la movilidad de las moléculas paramagnéticas es suficientemente rápido, todos los electrones desapareados sufrirán un mismo campo dipolar producido por su entorno, el cual ha sido promedio a cero por tales movimientos.

De esta manera el ancho de líneas de absorción puede ser ampliamente reducido por efecto del movimiento, y es por esto que los espectros en soluciones líquidas pueden ser de muy alta resolución, comparada con el mismo marcador en sólidos no orientados, en donde se obtiene líneas muy anchas. Con estados intermedios de movilidad, de manera que las orientaciones ocurren en tiempo comparable con la transición de spin, se logran espectros intermedios, es por esto que los espectros de EPR de sustancias paramagnéticas son sensibles a la movilidad y al grado de orientación de las moléculas. Teniendo en cuenta las anisotropías, la energía de los distintos niveles en ausencia de interacción spinspin estará dada por el Hamiltoniano

$\mathrm{H}=\mu_{\mathrm{b}} * \mathrm{~B} * \mathbf{G}^{*} \mathrm{~S}+\mathrm{S} * \mathbf{A}^{*} \mathrm{I}(8)$

donde S e I son los operadores de los spines electrónico y nuclear, y G y A son los tensores $g$ e hiperfino respectivamente.

El primer término representa las interacciones de Zeeman y el segundo se debe a la interacción hiperfina. Si se define un sistema de coordenadas, los componentes de los tensores $\mathrm{G}$ y $\mathrm{A}$ en las tres direcciones pueden calcularse introduciendo la sustancia paramagnética, y determinando el espectro de EPR en las tres direcciones respecto del campo magnético. Conociendo estos componentes principales, se puede calcular los valores esperados de g y de la separación hiperfina para cualquier orientación (Berliner, 1976). Esta anisotropía en los valores de G y de A son las bases para el cálculo del parámetro de orden S en membranas (Seelig, 1970).

Cuando una molécula paramagnética sufre movimiento isotrópico rápido en comparación con el tiempo asociado a una transición de spin, pueden desarrollarse ecuaciones para medir el tiempo de correlación $\tau$ para la rotación de la molécula (Morse II, 1986) directamente de la derivada del espectro, dado por la siguiente formula. 


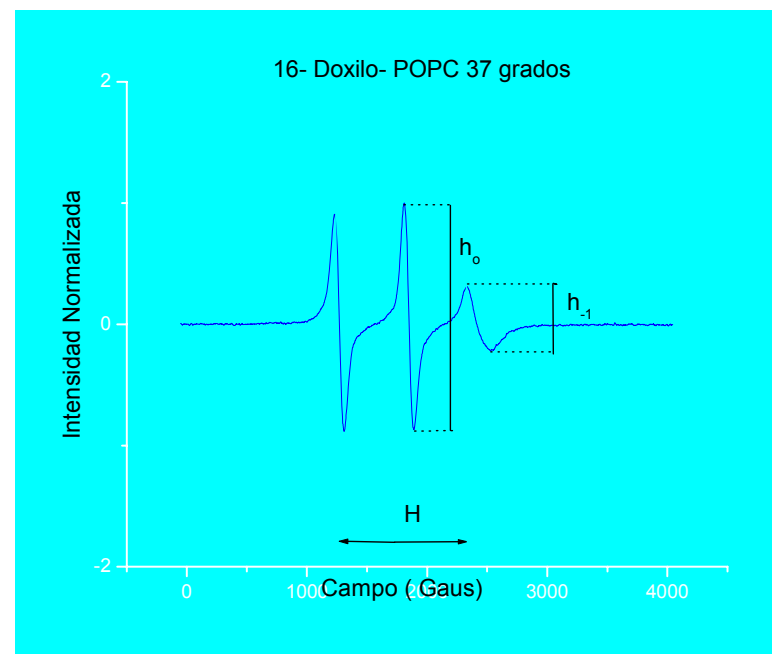

$\tau_{\mathrm{c}}=\mathbf{K} * \Delta \mathbf{H} *\left[(\mathrm{ho} / \mathrm{h}-1)^{1 / 2}-1\right]$

Fig.III- 8: espectro de EPR de Doxilo en donde se muestra los parámetros medidos, $\Delta \mathrm{H}$ es el ancho de pìco central, mientras que $\mathrm{h}_{0} \mathrm{y} \mathrm{h}_{-1}$ son las amplitudes de los picos de las lineas central y de campo alto

El tiempo de correlación rotacional puede ser utilizado para calcular la micro viscosidad aparente del medio de acuerdo a la ecuación de Stokes-Einstein, rigurosamente válido para cuando el marcador es mucho mayor que el solvente.

Pequeñas moléculas en medio isotrópico pueden sufrir movimientos anisotrópicos, (Goldman et al., 1972), (Hwang et al., 1975) caracterizándose así por lo menos dos tiempos de correlación, uno que caracteriza la rotación a través del eje principal de la molécula y otro que caracteriza el movimiento de dicho eje (Goldman et al., 1972), pero en sistema de membranas el calculo del tiempo de correlación es inexacto debido al ordenamiento de la molecular.

\section{Marcadores de spin}

Los marcadores de spin que usamos son radicales libres estables derivados del nitrógeno denominados nitroxilo, como ser Tempo y Doxil, (ver figura III-9 a y b respectivamente). Estos son estables gracias al efecto protector que le confiere el estar unido a un carbono terciario. El primero es anfifílo, mientras que al segundo se lo suele unir a un ácido graso para hacerlo liposoluble, la estabilidad es tal que no son casi reactivos, además de ser estables en un amplio rango de $\mathrm{pH}$ como así hasta $80^{\circ} \mathrm{C}$. El espectro de estos marcadores comprende tres líneas dadas por la interacción del electrón 2 pП de la unión N-O y el núcleo del ${ }^{14} \mathrm{~N}(\mathrm{I}=1)$ 

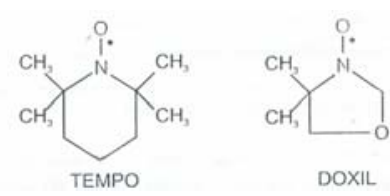

DOXIL

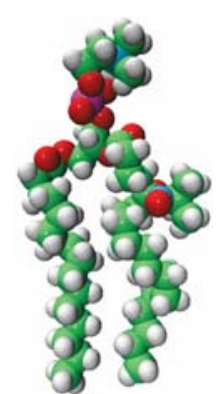

16:0-05-DOXYL- PC

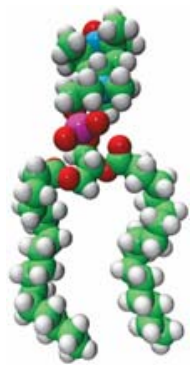

16:0 -TEMPO- PC

III-9 c)

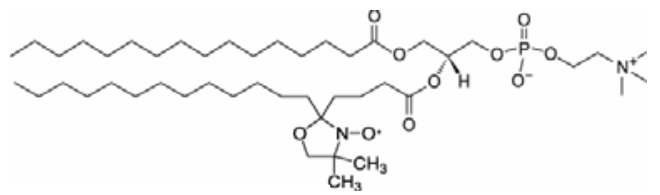

16:0-05-DOXYL- PC

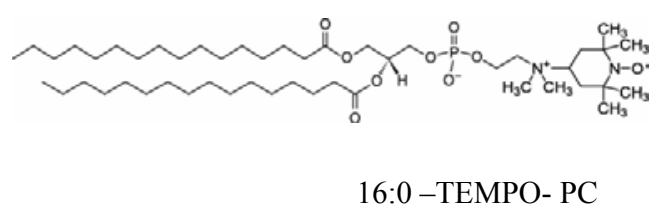

III-9 d)<smiles>CC(C)CCC[C@H](C)C1CCC2C3CC[C@H]4C[C@]5(CCC4(C)C3CCC21C)OCC5(C)C</smiles>

Fig III-9: se muestra en la fig. 9 a la estructura en linea de los marcadores de spin utlizados, mientras que en la 9 b y en la 9 c se muestran alguno derivados utilizados en sistemas lipidicos. 9 d) 3- $\beta$-DoxilColestano

Estos marcadores se encuentran unidos químicamente a distintas moléculas, el tempo se encuentra unido en fosfolípidos en la cabeza polar, mientras que el grupo Doxilo se encuentra sustituyendo al carbono $\mathbf{n}$ de un ácido esteárico libre o unido a un fosfolípido. Según el carbono que se encuentra sustituido se denomina n-doxil-ácidoesteárico, o su denominación en fosfolípido como ser 1-palmitoil- 2- $n$-doxil esteroil sn-glycero-3-fosfatidilcolina, los cuales denominaremos n-Doxil-PC. En la figura III-9 se grafica dos derivados de gran utilidad. En consecuencia al aumentar el n el marcador se encontrará más sumergido en la región hidrofóbica; y si bien el anillo doxil tiene un considerable tamaño respecto a otras moléculas estudiadas, la baja proporción utilizada (menos del $0.3 \%$ molar), permite suponer que no altera la estructura de los agregado que forma. Otro marcador de spin de gran utilidad es el 3- $\beta$-Doxil- Colestano, análogo de colesterol (fig. III-9d) 


\section{$\underline{\text { Parámetro de orden }}$}

Cuando los marcadores de los que hablamos son incorporados en sistemas lipídicos se ubican preferentemente con el eje molecular mayor paralelo a las cadenas alquilicas o acílicas de los otros lípidos y perpendicular a la superficie. El parámetro de orden es definido como una medida de distribución de las orientaciones moleculares respecto al eje de referencia, el cual es la perpendicular a la superficie determinado por la siguiente formula:

$\mathrm{S}=\left(3^{*}<\cos \alpha>-1\right) / 2$, siendo $\alpha$ el ángulo entre la perpendicular a la superficie y la dirección del eje $\mathrm{Z}$ alo largo del orbital 2pП del la unión N-O.

El parámetro de orden no involucra la velocidad de movimiento de los marcadores paramagnéticos, y asume que estos son suficientemente rápidos en el tiempo de transición spin-spin.

En el dibujo se muestran los posibles movimientos que puede tener un marcador de spin inserto en una membrana, el ángulo $\alpha$ es el forma con el eje $z$.

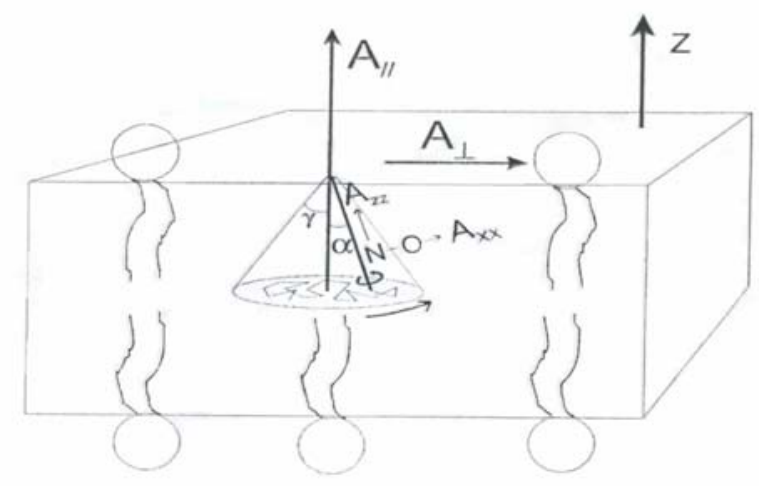

Fig.III-10: Movimiento de un grupo nitroxilo unido a una cadena carbonada de un ácido graso insertado en una membrana lipídica el ánguloa es el que forma el eje z del sistema de ejes del tensor hiperfino A del grupo nitróxilo con el eje normal $\mathrm{Z}$ de la bicapa. El cono $2 \gamma$ es el espacio en el cual se tambalea el grupo nitróxilo debido a las isomerizaciones trans-gauche

El acoplamiento hiperfino medido resultante de la promediación de Azz con Axx y Ayy se denomina A//, mientras que la promediación de Axx y Ayy con Azz se denomina $\mathrm{A} \perp$.

El parámetro de orden $\mathrm{S}$ en bicapas orientadas y cuando el eje $\mathrm{z}$ es paralelo al eje molecular como ocurre con nuestros marcadores, puede ser calculado por:

$\mathrm{S}=$ Anisotropía observada/ Máxima anisotropía $\left(\mathrm{A} / /-\mathrm{A}^{\perp}\right) /(\mathrm{Azz}-(\mathrm{Axx}+\mathrm{Ayy}) / 2)(10)$

La máxima anisotropía se calcula con los valores principales del tensor para un monocristal, y si estos no se conocen se puede usar los valores de un sistema congelado, 
multiplicando por un factor de corrección de polaridad. Los valores de anisotropía observada se calculan directamente del espectro.

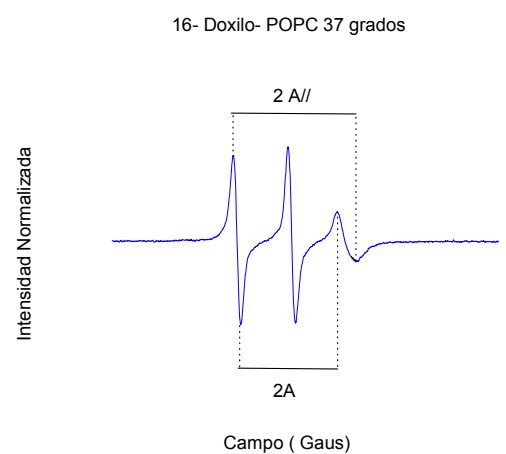

Fig. III-11 se muestra en la figura la derivada de un espectro de absorción de EPR, indicando cuales son los parámetros obtenidos del mismo para estimar el parámetro de orden

Cuando el sistema está ordenado el A// toma el valor de Azz y $\mathrm{A}^{\perp}=(\mathrm{Axx}+\mathrm{Ayy}) / 2$ y en consecuencia $\mathrm{S}=1$, cuando el sistema se empieza a desordenar $\mathrm{A} / /$ disminuye por contribución de $\mathrm{A}^{\perp}, \mathrm{y} \mathrm{A}^{\perp}$ aumenta por contribución de $\mathrm{A} / /$, y en consecuencia si está realizando movimientos isotrópicos rápidos, $\mathrm{A} / /$ es aproximadamente igual a $\mathrm{A}^{\perp} \mathrm{y} S=0$

En nuestro caso hemos comparado el parámetro de orden de un mismo marcador en dos condiciones distintas, como se explicara mas adelante.

\section{Método experimental utilizado}

La técnica de EPR se utilizó con dos propósitos; el primero observar si la interacción con membranas artificiales de apoA-I y del péptido A 77-120 producen modificaciones en la movilidad $u$ orden de sus lípidos constituyentes, para tal fin se utilizaron vesículas unilamelares (LUV), con y sin colesterol y a diferentes temperaturas, con diferentes marcadores de spin como se detallará mas adelante. El segundo de los propósitos fue observar el efecto de la apoA-I (cuando forma complejos discoidales con lípidos), sobre la movilidad $\mathrm{u}$ orden de los fosfolípidos de los complejos en los que se halla reconstituida (ver mas adelante). Los protocolos experimentales fueron los siguientes:

a) Vesículas lipídicas unilamelares grandes (LUVs): Se utilizaron vesículas de (POPC) y de POPC/colesterol (POPC/Col) en relación molar 4/1, conteniendo las 
distintas sondas de spin a una concentración $0,30 \%$ molar. Para esto se prepararon films a partir de soluciones stock de los lípidos, el solvente se evaporó con $\mathrm{N}_{2}$, dejándolas a baja presión por dos horas para eliminar los restos de solvente; luego los lípidos fueron resuspendidos por agitación en buffer fosfato $10 \mathrm{mM}, \mathrm{pH}=7.6$, sonicados por diez minutos y por último extruidos a través de filtros de poli carbonatos de $100 \mathrm{~nm}$ promedio, durante $\sim$ diez ciclos. La concentración final de las vesículas fue de $10 \mathrm{mM}$. (nota: el método de preparación de vesículas unilamelares será siempre el mismo, mas allá que se usen o no marcadores de spin). Los marcadores utilizados fueron TempoPC, y n-Doxil-PC ( $n=5,9,10,12,14$ o 16), y un análogo de colesterol 3- $\beta$-DoxilColestano

Condiciones de incubación con apoA-I: las muestras fueron preparadas agregando vesículas hasta una concentración final de $6 \mathrm{mM}$, y proteína o péptido hasta una relación molar lípido/proteína de 15/1, a esta relación la mayor parte de la proteína está unida a membrana (Toledo et al., 2000), se incubó durante un hora, a las temperaturas de 37, 25, y 5 grados centígrados, y luego se registró el espectro mediante EPR.

b) Vesículas lipídicas discoidales conteniendo apoA-I: en este caso se estudió mediante EPR la cinética de lipidación de apoA-I. En primer lugar se obtuvieron liposomas multilamelares (MLV) de 1,2-dimiristoil-fosfatidilcolina (DMPC), con las distintas sondas de spin a una concentración $0,30 \%$ molar. Para esto se prepararon films a partir de soluciones stock de los lípidos, luego de evaporarlas con $\mathrm{N}_{2}$ fueron dejadas a baja presión por dos horas para eliminar los restos de solvente, y por último fueron resuspendidas por agitación en buffer fosfato $10 \mathrm{mM}, \mathrm{pH}=7,6$.

Condiciones de incubación: las muestras fueron preparadas agregando apoA-I a vesículas a una concentración final de DMPC de $6 \mathrm{mM}$, hasta alcanzar una relación molar lípido/proteína de $40 / 1$ a $37{ }^{0} \mathrm{C}$ ya que a esta temperatura la formación de discos es muy lenta. Luego la mezcla fue llevada rápidamente a $24{ }^{0} \mathrm{C}$ en el espectrómetro (en condiciones de Tt de la DMPC donde la reacción es rápida (Swaney and Chang, 1980), y se siguió la cinética, midiendo espectros a distintos tiempos. Por último se miden los espectros de EPR a distinta temperatura (por encima y debajo de la $\mathrm{Tt}$ ).

Espectroscopia de EPR: Las medidas de EPR fueron realizadas en un espectrómetro Bruker EMX. La amplitud de modulación de $1 \mathrm{G}$ y el poder de microonda es de $10 \mathrm{~mW}$. El control de temperatura es dentro $0.2^{\circ} \mathrm{C}$ en forma variable fue realizado con Bruker 
BVT-2000, y monitoreada con Fluke 51 K:J. El campo magnético es medido con Gaussimetro Bruker ER 035 NMR, y los datos son convertidos a escala con software WINEPR (bruker). 


\subsection{Fluorescencia (Lakowicz, 1999)}

La luminiscencia es la emisión de fotones desde estados electrónicamente excitados. Esta se divide en dos tipos, dependiendo de la naturaleza del estado basal y del estado excitado. En un estado singulete (o singlete) el electrón en el orbital de energía superior tiene la orientación opuesta al del segundo electrón del estado energético inferior, por lo que se dice que estos dos electrones están apareados. Si el electrón en el estado excitado tiene la orientación igual al del estado energético inferior, se dice que estos dos están desapareados, y el sistema será un triplete. El retorno al estado basal de un estado singlete, no requiere que el electrón cambie de orientación, sin embargo si el retorno es desde un estado triplete requerirá que el electrón cambie de orientación. La fluorescencia es la emisión que resulta del regreso un electrón apareado a su nivel basal. Esta transiciones están cuánticamente "permitidas", y la velocidad de emisión son del orden de $10^{8} \mathrm{sec}-1$, por lo que la vida media del estado excitado es del orden de $10^{-8} \mathrm{seg}$. (10nseg). La Fosforescencia es la emisión resultante del retorno de estados excitados de distintas multiplicidad, generalmente de estados excitados tripletes que retornan a estados basales singuletes, dicha transición no esta "cuánticamente" permitida y la emisión es muy lenta, por lo que se traduce en vidas medias de los estados excitados en el orden de mseg.

Las sustancias que poseen capacidad fluorescente, poseen por lo general electrones deslocalizados, típicamente en dobles enlaces conjugados.

Lo antes dicho está esquematizado en los diagramas de A. Jablonski.

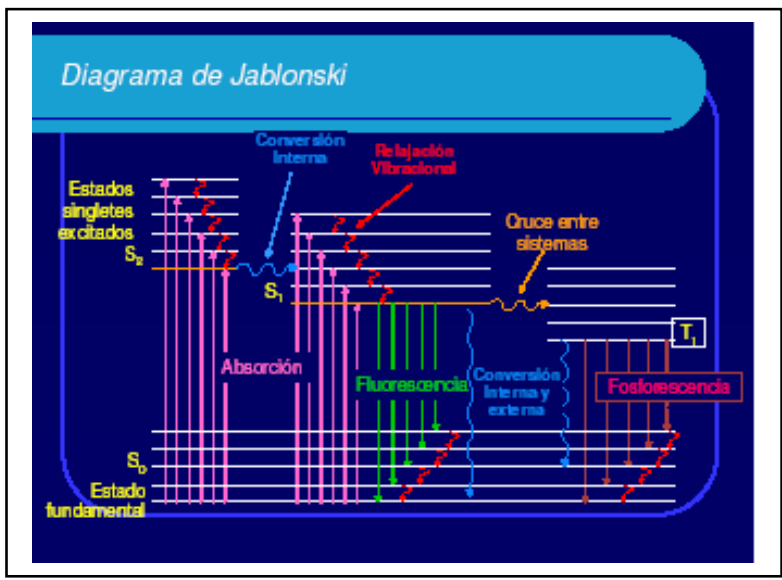

Fig.III-12 Los estados basales están representados por $\mathrm{S}_{0}$, mientras que los primeros estados electrónicos superiores son $\mathrm{S}_{1}$ y $\mathrm{S}_{2}$; en los fluoróforos pueden existir diferentes estados vibracionales determinados por 1,2,3.etc. La absorción está representada en forma vertical ascendente, ya que ilustra a la absorción como un proceso instantáneo, dicho proceso ocurre en el orden de $10^{-15}$ seg. Que es un tiempo muy corto para que se produzca un desplazamiento nuclear significativo. 
La distribución de Boltzman describe la relación de moléculas existente entre lo estados vibracionales 0 y 1

$$
\mathrm{R}=\mathrm{e}^{-\Delta \mathrm{E} / \mathrm{kT}}
$$

En donde $\Delta \mathrm{E}$ es la diferencia de energía entre los dos niveles, y el producto $\mathrm{kT}$ es la energía térmica del sistema, entonces a temperatura ambiente o por lo general, la de trabajo, el valor de $\mathrm{R}=0.01$, por lo que la absorción ocurre desde el nivel inferior.

Luego de la absorción de luz, pueden ocurrir varios procesos. Entre ellos puede ocurrir que un fluoróforo es excitado a niveles vibracionales superiores a S1 o también a $\mathrm{S} 2$. Salvo por excepciones, las moléculas suelen relajarse rápidamente a los niveles vibracionales inferiores de S1. Este proceso se llama ínter conversión interna que ocurre en $10^{-12} \mathrm{seg}$. Este tiempo relativamente corto en relación a la vida media de la fluorescencia, hace que la conversión interna ocurra casi completamente previa a la emisión. Así la emisión de fluorescencia ocurre desde estados excitados térmicamente equilibrados. La desexcitación ocurre asimismo a niveles vibracionales superiores de S0, ocurriendo la conversión interna a posteriori.

Los espectros de fluorescencia son presentados como espectros de emisión, en los cuales se determina el cambio de intensidad de fluorescencia en función de la longitud de onda, esta emisión dependerá de la estructura química del fluoróforo y del solvente en que se encuentre disuelto, como también del entorno en que se encuentre. A fin de estudiar estructura proteica puede utilizarse fluoróforos sintéticos (fluoresceína, etc), ó utilizar la capacidad de fluorescencia intrínseca de algunos aminoácidos, como ser Tirosina (Tyr), Triptofano (Trp) o Fenilalanina (Phe) dada por los grupos aromáticos que estos aminoácidos poseen

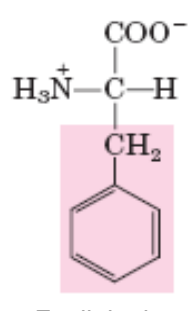

Fenilalanina
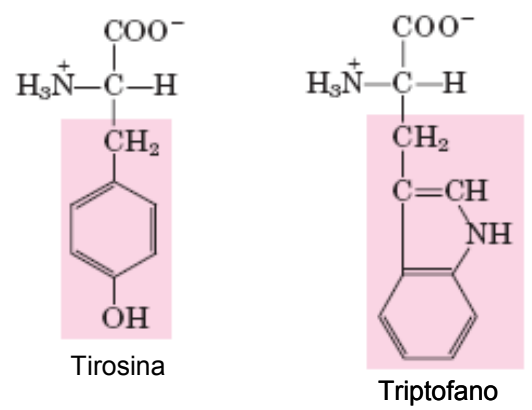

Fig.III-13: Se muestran los grupos aromáticos de los aminoácidos fluorescentes 
El grupo indol del Trp es el que hace que las proteínas absorban y emiten luz en la región del Ultra violeta del espectro. La Tyr tiene una intensidad de emisión similar a la del Trp, pero su máximo de emisión esta dada en longitudes de onda menores que la de éste y puede ser quencheada (apagada) su fluorescencia por interacciones con péptidos o por transferencia de energía (ver mas adelante) con el Trp, además la misma aumenta en proteína desnaturalizadas, debido a cambios en el $\mathrm{pKa}$ del fenol que favorecerían el estado excitado. La fluorescencia de la fenilalanina adquiere importancia cuando en proteínas no existe residuos de Trp o de Tyr, cosa que raramente ocurre. La emisión del Trp es altamente sensible al ambiente que lo rodea, sufriendo un corrimiento hacia longitudes de onda mayores (hacia el rojo del espectro) cuando el medio al que se expone este residuo es acuoso. La fluorescencia del Trp puede ser quencheada por diferentes grupos, como ser $\mathrm{I}^{-}$, acrilamida, grupos disulfuro o radicales libres como los nitroxilos utilizados en EPR. En la Figura III-14 se resumen las propiedades espectrales mencionadas para estos aminoácidos.

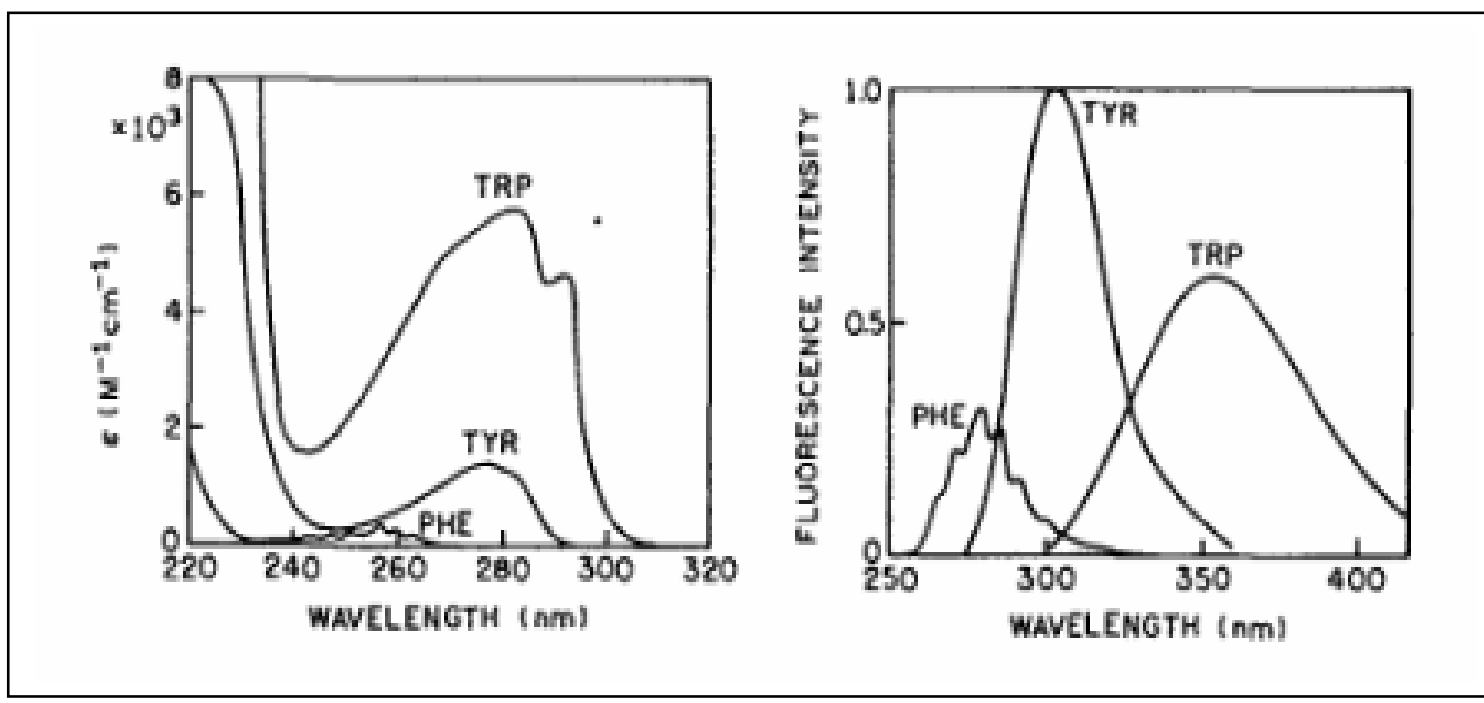

\begin{tabular}{|l|l|l|l|l|}
\hline aminoácido & $\boldsymbol{\lambda}_{\text {exit. }}(\mathbf{n m})$ & $\boldsymbol{\lambda}$ emis. $(\mathbf{n m})$ & Eficiencia cuántica & vida media (ns) \\
\hline Fenilalanina & 260 & 282 & 0.02 & 6.8 \\
\hline Tirosina & 275 & 304 & 0.14 & 3.6 \\
\hline Triptpfano & 295 & 353 & 0.13 & 3.1 \\
\hline
\end{tabular}

Fig.III-14: arriba se observan espectros de absorción y de emisión de los mismos en un medio acuoso abajo se sintetiza en la tabla las caracteristicas espectrales de los aminoácidos mencionados en solución acuosa a $\mathrm{pH} 7$

En este trabajo se estudió la información espectral del Trp mediante la intensidad de fluorescencia, o el corrimiento del máximo de emisión. La primera 
depende de la concentración de fluoróforo, de la interacción del mismo con su entorno, de la transferencia de energía con la misma especie o con otra, etc y por lo tanto del rendimiento cuántico.

El segundo proceso es llamado corrimiento de Stokes. Excepto para átomos en fase vapor, una observación que siempre ocurre en fluorescencia es la emisión a longitudes de onda mayores que la de excitación, o sea que la emisión es con pérdida de energía. Este proceso puede tener varias causas; una causa común es el rápido descenso a los niveles vibracionales más bajos de $\mathrm{S} 1$, es más, los fluoróforos muchas veces caen a niveles vibracionales de S0 (ver fig. III-12), resultando en pérdidas adicionales de energía; los fluoróforos pueden presentar además, corrimientos adicionales debido a la relajación de los estados excitados ocasionados por solventes polares, ó sufrir reacciones químicas durante el estado excitado.

\section{$\underline{\text { Anisotropía de fluorescencia }}$}

Los fluoróforos por lo general absorben fotones cuyos vectores eléctricos se encuentran alineados paralelos al momento de transición del fluoróforo. En una solución isotrópica, los fluoróforos son moléculas orientadas al azar. Si se irradia moléculas con luz polarizada, se seleccionarán selectivamente aquellas cuyos dipolos de absorción se encuentren paralelos al vector eléctrico de excitación. Esta "selección selectiva" o foto selección de moléculas parcialmente orientadas, resulta en la emisión de luz parcialmente polarizada. Los momentos de transición para la absorción y la emisión tiene orientaciones fijas para cada fluoróforo, y el ángulo relativo entre estos momentos determina la máxima anisotropía medida.

La anisotropía de fluorescencia esta definida por

$$
\mathrm{r}=\left(\mathrm{Iv}-\mathrm{I}_{\mathrm{H}}\right) /\left(\mathrm{Iv}+2 \mathrm{I}_{\mathrm{H}}\right)
$$

en donde $\mathrm{Iv}$ e $\mathrm{I}_{\mathrm{H}}$ son las intensidades de fluorescencia de las emisiones de luz polarizadas vertical y horizontalmente, respectivamente. Debido a la foto selección de los fluoróforos, la anisotropía puede tomar valores entre -0.2 y 0.4 . La disminución de anisotropía está dada generalmente por movilidad o difusión rotacional del fluoróforo, que ocurren durante la vida media del estado excitado y desplazan el dipolo de emisión 
de la molécula. Otro proceso de disminución de anisotropía ó despolarización es la transferencia de energía.

\section{$\underline{\text { Transferencia de energía }}$}

Es el proceso por el cual la energía de una molécula excitada o donor, es cedida a otra que actúa como aceptor, esta transferencia ocurre sin emisión de fotones y es el resultado, primariamente de la interacción dipolo-dipolo entre el donor y el aceptor. El grado de transferencia de energía depende del solapamiento entre el espectro de emisión del donor y el de absorción del aceptor, la orientación relativa entre los dipolos de transición de ambos, y de la distancia entre ambas moléculas. Esta dependencia de la distancia es lo que hace a esta medida sumamente útil, ya que permite determinar la distancia entre las moléculas que actúa como donor y la actúa como aceptor.

La velocidad de transferencia de energía desde un donor a un aceptor (Kt), está dada por:

$$
\mathrm{Kt}=1 / \tau\left(\mathrm{R}_{0} / \mathrm{r}\right)^{6}
$$

en donde $\tau$ es el tiempo de vida medio del donor en ausencia del aceptor, "r" es la distancia entre ambas moléculas y $\mathrm{R}_{0}$ es una distancia característica, llamada de Förster, que es la distancia en donde la eficiencia de transferencia de energía es del 50\%. Esta dependencia es útil para distancias que van desde 20 a $50 \AA$, las que son típicas ó comparables a distancias intramoleculares en proteínas y al espesor de las membranas biológicas.

La transferencia de energía puede ocurrir entre moléculas químicamente diferentes, llamándose Hetero transferencia, o entre moléculas iguales, denominándose Homo transferencia. Este tipo de transferencia ocurre en fluoróforos cuyos espectros de absorción y emisión están en cierto grado solapados. En este trabajo se ha usado la medida de homo transferencia para determinar la cercanía de fluoróforos.

Usualmente la determinación de transferencia de energía es por medio de la observación en cambios de intensidad o en la vida media de las moléculas aceptor o donor, estas observaciones se aplican cuando las moléculas son diferentes, o sea para heterotransferencia de energía. Cuando se determina homotransferencia, como ser el caso del Triptofano en las proteínas, se dificulta la observación de este efecto y se 
determina en cambio eficiencia de transferencia basada en anisotropía. Fluoróforos que exhiben pequeños corrimientos de Stokes (cierto grado de solapamiento entre espectros de excitación y emisión), pueden sufrir homotransferencia, la que puede ser detectada por la depolarización resultante de la emisión.(Weber, 1960) (Hamman et al., 1996). La eficiencia de la transferencia de energía en ese caso puede ser determinada mediante la determinación de anisotropía en presencia y en ausencia de transferencia, según la expresión

$\left.\mathrm{E}=2\left(\mathrm{r}_{0}-<\mathrm{r}>\right) / \mathrm{r}_{0}\right) \quad($ Hamman et al., 1996)

donde $\mathrm{r}_{0} \mathrm{y}<\mathrm{r}>$ son las anisotropías en ausencia y presencia de homotransferencia, respectivamente. Como fue descrito por Weber (Weber, 1960), la homotransferencia desaparece cuando se excita en el extremo rojo de espectro.

Para estimar la distancia en que se encuentran los residuos de Trp de diferentes moléculas de proteína se utilizó la homotranferencia de energía de las mutantes puntuales de apoA-I en solución y cuando se encuentran formando complejos lipoproteicos discoidales, estos últimos obtenidos por micelización directa o por diálisis con colato de sodio.

\section{Quenching o apagado de fluorescencia}

La intensidad de fluorescencia puede decaer por varios procesos, dichos procesos se denominan quenching o apagamiento de la fluorescencia, y ocurre cuando el fluoróforo excitado vuelve al estado basal sin emitir fotones debido al contacto con la molécula "quencheadora” ó apagadora.

Existen dos procesos por el cual el quenching puede ocurrir, uno en donde la molécula en su estado excitado le transfiere energía al quencher cuando colisiona, denominándose el proceso "quenching dinámico ó colisional”, o cuando el fluoróforo en su estado fundamental forma un complejo con el quencher, el cual se relaja por procesos que no emiten fotones (ver Figura III-15) 


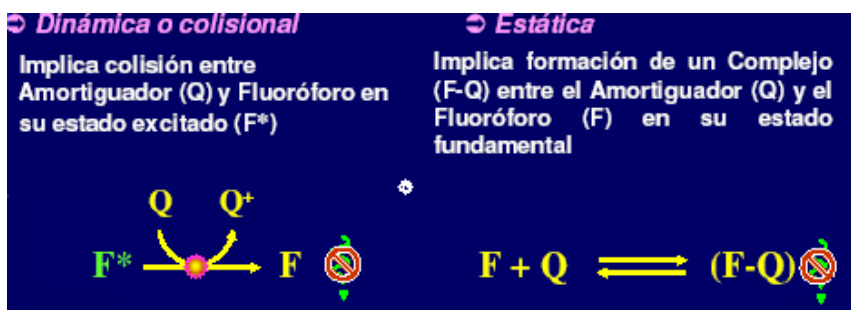

Fig.III-15:

esquematización de diferentes procesos por lo cual la fluorescencia puede ser apagada

Existen muchos tipos de moléculas apagadoras o amortiguadoras, pero es importante que no todas actúan sobre todos los fluoróforos. El decaimiento de la intensidad de fluorescencia está descrita por la ecuación de Stern-Volmer:

$\mathrm{Fo} / \mathrm{F}=1+\mathrm{K}[\mathrm{Q}]$, en donde Fo es la intensidad del fluoróforo en ausencia del quencher, $\mathrm{F}$ es la intensidad en presencia del mismo y K la constante de Quenching.

En este trabajo se usaron como agente apagador las mismas moléculas de Doxilos a distintas alturas como las utilizadas en los estudios de EPR para poder determinar el modo de inserción de la apoA-I en vesículas unilamelares. Para esto se utilizaron las mutantes simples de Triptofano en las posiciones 93, 104 y 108, las cuales se titularon con vesículas unilamelares hechas como se mencionó más arriba, pero con una cantidad de apagador de un $20 \%$ en moles, modificándose la ecuación anterior a una similar de binding.

El tratamiento matemático del apagamiento o quenching, y la accesibilidad al mismo es explicado y desarrollado en los resultados. 
CAPÍTULO IV:

RESULTADOS 
Parte A

Rol e independencia funcional de las hélices Y centrales de Apo A-I en la interacción con membranas. Estudios con un péptido sintético 


\section{Parte A: Rol e independencia funcional de las hélices $Y$ centrales de apo A-I en la interacción con membranas. Estudios con un péptido sintético}

Para ensayar la hipótesis de que las hélices Y centrales de apoA-I se comportan como un dominio estructural y funcionalmente independiente del resto de la molécula de la proteína, se trabajó con un péptido sintético con la secuencia de apoA-I comprendida entre los residuos 77 y 120 (AI 77-120). Esta secuencia se extiende entre la última parte de la hélice 2 (tipo A) y a las hélices 3 y 4 (tipo Y) completas que fueron predichas y encontradas en la estructura cristalina de $\Delta 1-43$ apoA-I, o al loop que separa las hélices B-C y la primera parte de la hélice $\mathrm{C}$ en la estructura cristalina de apoA-I completa (ver Fig I-9, I-10 yI-11 en Introducción). La racionalidad de extender hacia ambos lados la región que se marca con el reactivo fotoactivable (87-112) se basó en abarcar al menos toda la región homóloga con ectatomin de manera de aumentar la probabilidad de que el péptido adquiera un cierto grado de estructuración en agua, hecho que no es muy frecuente en péptidos cortos. Se investigó la capacidad de AI 77120 para interactuar con vesículas lipídicas e insertarse en membranas fosfolipídicas artificiales, y su estructura secundaria y cuaternaria en los estados libre y unido a membrana. En colaboración con otro integrante del grupo (Dr. J. D. Toledo) también se comparó la actividad de este péptido con la de apoA-I completa para desorber colesterol de membranas y catalizar su intercambio entre vesículas.

\section{Afinidad de AI77-120 por membranas fosfolipídicas}

La apoA-I, ya sea cuando está libre de lípidos (Yokoyama et al., 1980) ó en la forma de rHDL (Tricerri et al., 1998) posee una mayor afinidad o selectividad por membranas y/o vesículas que poseen colesterol respecto a aquellas que no lo poseen. Para determinar si el péptido AI 77-120 mantiene esta propiedad, se midió su afinidad por vesículas de POPC y de POPC/colesterol (4:1 relación molar). Vesículas unilamelares pequeñas (SUVs) fueron obtenidas por sonicación de MLV en un sonicador de punta, usando pulsos de 4 seg. Luego de incubar $3.5 \mathrm{nmol}$ de AI77-120 con cantidades crecientes de SUV de POPC ó POPC/Colesterol (4/1 relación molar) por 5 min a temperatura ambiente, la mezcla fue ultrafiltrada a través de filtros Microcon 50. La concentración del péptido libre en el ultrafiltrado se determinó por la fluorescencia de triptofano ( $\lambda$ exitación $280 \mathrm{~nm}, \lambda$ emisión $340 \mathrm{~nm}$ ). Alternativamente, 
0,2 $\mathrm{ml}$ del filtrado fueron inyectados en la misma columna de HPLC de fase reversa usada en la purificación de AI 77-120 (ver Materiales y Métodos) y la concentración del péptido se deteminó del area del pico obtenido por detección de absorbancia a $280 \mathrm{~nm}$. En ambos casos se usó una solución de concentración conocida de AI 77-120 como referencia.

Los datos obtenidos se muestran en la figura IV-1. Los mismos fueron interpretados asumiendo un modelo simple con sitios de unión independientes y no interactuantes. Con este modelo, la cantidad de péptido libre sigue la siguiente ecuación:

$$
\left.\mathrm{Pf}=\left((\mathrm{Pt}-\mathrm{Kd}-\mathrm{PC} / \mathrm{n}) \pm \sqrt{ }(\mathrm{PC} / \mathrm{n})^{2}\right)+2 \mathrm{PC}(\mathrm{Kd}-\mathrm{Pt}) / \mathrm{n}+(\mathrm{Kd}+\mathrm{Pt})^{2}\right) / 2 \text { (ecuación1) }
$$

en donde Pt es la cantidad de péptido total, Pf es la cantidad de péptido libre, Kd es la constante de disociación, PC es la cantidad total de vesículas en concentración de fosfatidilcolina y $\mathbf{n}$ el número de moléculas de fosfatidilcolina que conforman un sitio de unión.

Los resultados indican que AI 77-120 se comporta similarmente a apoA-I en cuanto a que presenta selectividad o preferencia por vesículas fosfolipídicas que contienen colesterol. Los valores de Kd obtenidos para AI 77-120, sin embargo, son un orden de magnitud menor que los obtenidos por Yokoyama y col. (Yokoyama et al., 1980) para la unión de apoA-I libre a vesículas de PC de huevo, o por Tricerri y col. (Tricerri et al., 2002) a vesículas de POPC; aunque son del mismo orden que los obtenidos por estos últimos autores para el caso de complejos lipoproteicos discoidales reconstituidos con apoA-I. El número de moléculas de $\mathrm{PC}$ que conforman un sitio de unión para AI 77-120 es alrededor de 50 en el caso de POPC pura y alrededor de 32 en el caso de vesículas de POPC/Col (4/1 en mol). Estos valores son también alrededor de uno a dos órdenes de magnitud menores que los reportados por esos autores para la apoA-I completa, mientras que un valor intermedio fue reportado por Tricerri para complejos lipoproteicos discoidales.

Los parámetros obtenidos sugieren que el modo de unión a vesículas de AI 77120 sería similar a apoA-I cuando ésta se encuentra en complejos discoidales, con sólo las hélices centrales participando en dicha unión ya que las otras estarían comprometidas en la unión a los lípidos del disco. El mayor tamaño de los complejos discoidales en relación al péptido AI 77-120 puede explicar que en el primer caso se requiera un mayor número de moléculas de PC para conformar un sitio de unión. En el 
caso de la apoA-I libre de lípidos, todas la hélices anfipáticas participan en la unión a las vesículas por tanto contribuyen a su mayor afinidad, aunque como se mencionó, sólo la región central se inserta profundamente en la membrana de manera de ser marcada por el reactivo ${ }^{125} \mathrm{I}-\mathrm{TID} / \mathrm{PC}$ (Corsico et al., 2001). Con todas las hélices anfipáticas interactuando con la superficie de la membrana, es esperable que en este caso el número de moléculas de PC que conforman un sitio de unión para apoA-I sea aún mayor que para los complejos discoidales.

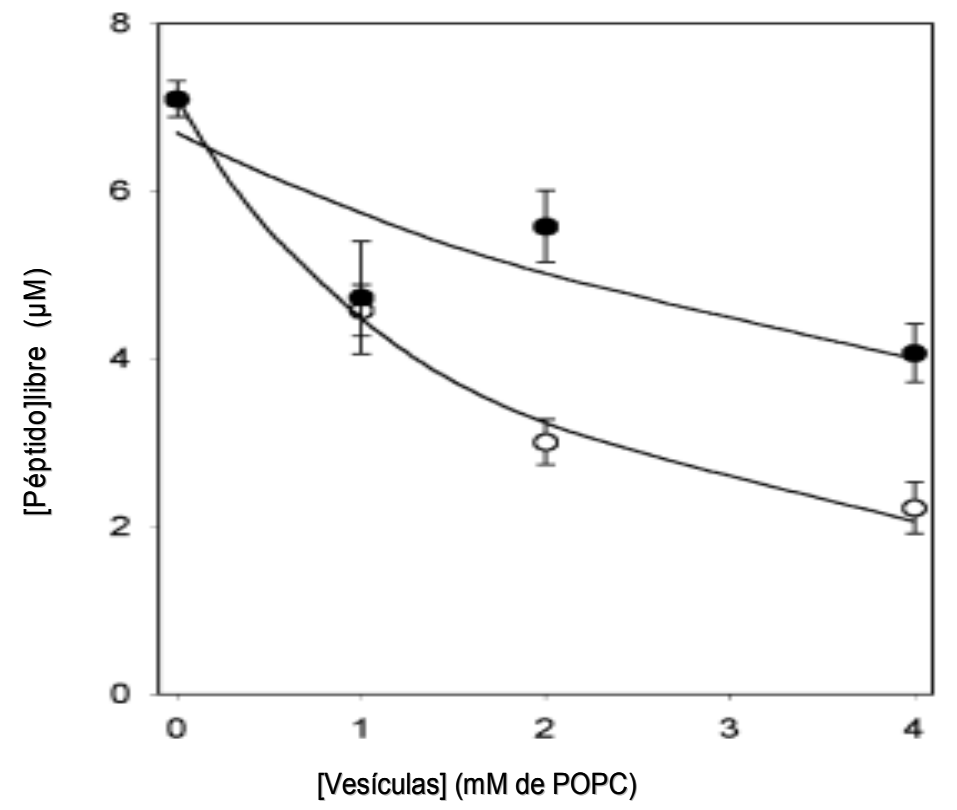

Fig. IV-1: Unión del péptido AI 77-120 a vesículas unilamelares de POPC (negro) y de POPC/Colesterol (en blanco). Se muetran la media y desvío estandard de tres determinaciones independientes. Las líneas son los mejores ajustes de la ecuación 1 a los datos experimentales, de los que se obtuvieron los siguientes parámetros: $\mathrm{Kd}=122 \pm 40 \mu \mathrm{M}$ y $\mathrm{n}=47 \pm 14$ moléculas de $\mathrm{PC}$ por sitio de unión con las vesículas de POPC; y Kd $=49 \pm 3 \mu \mathrm{M}$ y $\mathrm{n}=32 \pm 2$ moléculas de PC por sitio de unión con las vesículas de POPC/colesterol. 


\section{Marcación por reactivos fotoactivables}

Con el fin de conocer si AI 77-120 se inserta profundamente en la bicapa de las vesículas fosfolipídicas como lo hace la región central de apoA-I, se estudió en comparación con ésta la capacidad de ser foto marcado por el análogo fosfolipídico ${ }^{125} \mathrm{I}$ TID-PC (ver Introducción) incorporado en vesículas fosfolipídicas. El grupo reactivo de este compuesto (diazirina) se localiza bien en el interior de la bicapa lipídica. Cuando es activado por exposición a luz ultravioleta genera un carbeno muy reactivo que se entrecruza covalentemente con todos los grupos químicos que se encuentran en la cercanía, y podrá así marcar con ${ }^{125} \mathrm{I}$ a las regiones de la proteína o al péptido que se inserten profundamente en la membrana. Para este ensayo se prepararon vesículas unilamelares de POPC/Col (en relación molar 4/1), incluyendo el reactivo fotoactivable 1-O-hexadecanoil-2-O-(9[[2-[ $\left.{ }^{125} \mathrm{I}\right]$ iodo-4-(trifluorometil-3H-diazirina-3-il) benzil] oxi] carbonil] nonanoil]-sn-glicero-3-fosfocolina ( $\left.{ }^{125} \mathrm{TID}-\mathrm{PC} / 16\right)(1 \mathrm{mCi} / \mathrm{nmol} \mathrm{de} \mathrm{POPC})$. Estas vesículas (25 nmol de POPC) fueron incubadas a temperatura ambiente por 1 minuto con AI77-120 ó apoA-I (2 nmol) en 0,1 ml de buffer Tris-HCl $10 \mathrm{mM}, 0,15 \mathrm{M}$ $\mathrm{NaCl} \mathrm{pH} 8,0$ y se fotoactivaron por 30 segundos con una lámpara de Xenón. Se extrajeron los lípidos con cloroformo/metanol $(2: 1)$ y la fracción acuosa se trató con acetona a $-20^{\circ} \mathrm{C}$, para precipitar a AI77120 ó apoA-I. La radiactividad del precipitado se contó en un contador gamma.

\begin{tabular}{|c|c|}
\hline Muestra & $\begin{array}{c}\text { Radiactividad en el } \\
\text { precipitado con } \\
\text { acetona(cpm/nmol de } \\
\text { proteína) }\end{array}$ \\
\hline apoA-I & 15.380 \\
\hline AI 77-120 & 42.069 \\
\hline
\end{tabular}

Se puede observar que en estas condiciones, AI 77-120 es fotomarcado con una mayor eficiencia que apoA-I. La relación de concentración proteína (o péptido) a vesículas usada en este ensayo es mucho mayor que las usadas en los ensayos de unión por lo que las condiciones son más cercanas a saturación. Así, aunque la afinidad es menor para AI 77-120 que para apoA-I, su mayor eficiencia de marcado se debería al mayor número de sitios de unión. 


\section{Cambios estructurales de AI 77-120 en la interacción con membranas: estudios de estructura secundaria por dicroísmo circular}

El dicroísmo circular permite estudiar la estructura secundaria proteica, mediante el análisis de su espectro de absorción en el UV lejano, cuando la muestra es iluminada con luz circularmente polarizada. Mediante el análisis de dicho espectro en comparación con el de proteínas cuya estructura es conocida, distintos programas predicen el porcentaje de aminoácidos organizados en forma de hélice $\alpha$, hoja $\beta$ ó estructura desorganizada (Leroy et al., 1993)

De este modo se puede asimismo, estimar el cambio conformacional asociado a la interacción de proteínas con membranas. Para tal fin, se determinó el espectro del péptido (a una concentración $15 \mu \mathrm{M}$ ), a $28{ }^{\circ} \mathrm{C}$ en una celda de $1 \mathrm{~cm}$ de paso, en un espectrómetro Jasco Modelo 715

La figura IV-2 muestra los espectros de AI 77-120 en solución acuosa y en 50\% de trifluoroetanol. Usando el programa Varselec (Toumadje et al., 1992), se estima que AI 77-120 tiene un 23\% de $\alpha$-hélice en solución acuosa. Esto significa un grado de estructuración relativamente alto considerando el pequeño tamaño del péptido (44 residuos), y el hecho de que la molécula completa de apoA-I (243 residuos) en agua tiene alrededor de 56\% de $\alpha$-hélice. En trifluoroetanol, el contenido de hélice se incrementa a un 64\%, indicando que AI 77-120 es capaz de adquirir un mayor contenido de $\alpha$ hélice en función del medio (Leroy et al., 1993)

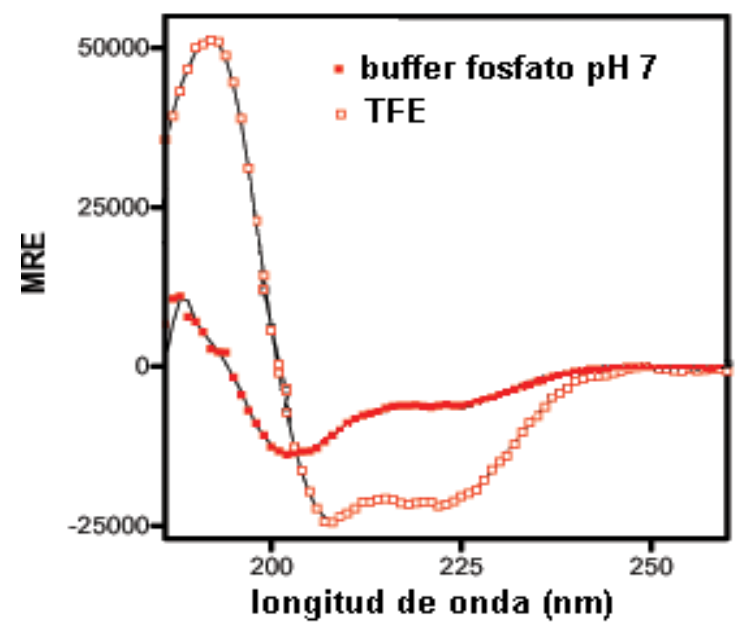

Fig. IV-2: Espectros de dicroísmo circular de AI77-120 en 5mM fosfato de sodio $\mathrm{pH}$ 7,0 y 50\% de trifluoroetanol (TFE). De los mismos se obtuvo un contenido de $\alpha$-hélice de 23 y $64 \%$ en buffer acuoso y TFE, respectivamente. 
El contenido de $\alpha$-hélice de la apoA-I completa se incrementa cuando esta se une a lípidos, al menos cuando se encuentra en forma de complejos discoidales reconstituidos (Tricerri et al., 2002). Esto, así como también hecho de que el contenido de $\alpha$-hélice del péptido sea dependiente del medio, nos indujo a estudiar la posibilidad de que la estructura secundaria pueda ser modificada cuando AI 77-120 se une a vesículas lipídicas. Para ello, los espectros de dicroísmo circular se midieron con cantidades crecientes de vesículas unilamelares de POPC/Col (4:1) (fig. IV-3). Al incrementar la concentración de vesículas, la calidad de los espectros es notoriamente deteriorada en especial a menores longitudes de onda debido al aumento en la luz dispersada y al ruido introducido al restar los espectros de las vesículas. Por esta razón, además de la relativamente baja afinidad del péptido por las vesículas, no es posible medir en condiciones en que un alto porcentaje del péptido se encuentre unido a las vesículas. Sin embargo, estos experimentos indican que no hay cambios detectables en el espectro de CD cuando se agregan hasta $1.8 \mathrm{mg} / \mathrm{ml}$ de vesículas de POPC/colesterol (4/1 en moles). Usando los parámetros que se obtuvieron de los datos de la figura 11, puede estimarse que en estas condiciones al menos 35-40\% de AI 77-120 se encontraría unida a las vesículas. Así, puede concluirse que la unión de AI 77-120 a las vesículas ocurre sin grandes cambios en la estructura secundaria.

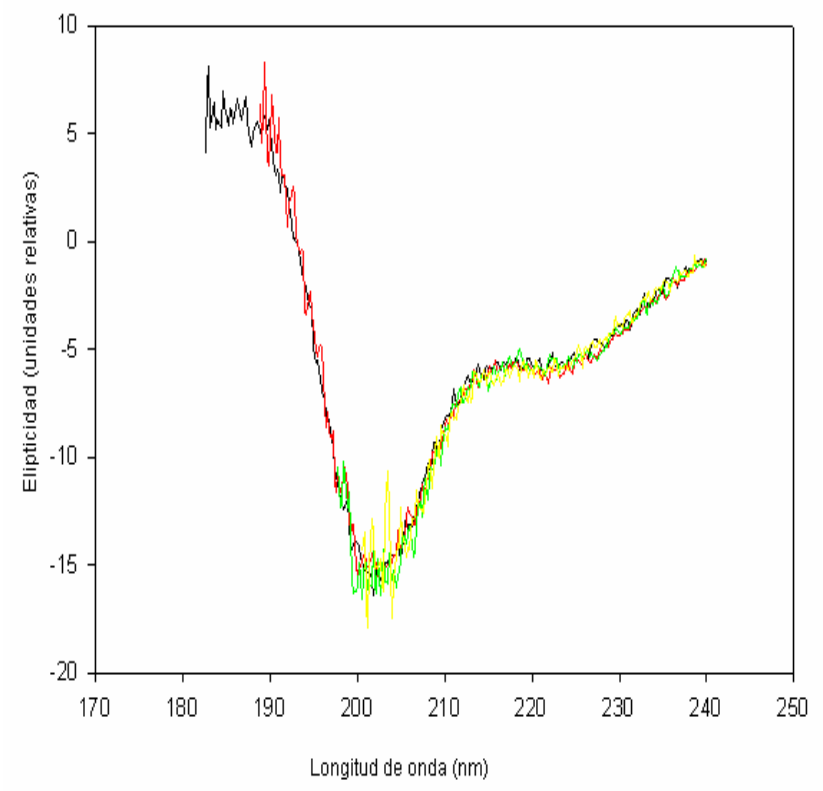

Fig. IV-3: Efecto de vesiculas lipidicas sobre la estructura secundaria del péptido AI 77-120. Espectros de CD de AI $77-120(30 \mu \mathrm{M})$ con cero (línea negra), 0,6 (línea roja), 1,2 (línea verde), y 1,8 (línea amarilla) $\mathrm{mg} / \mathrm{ml}$ de vesículas unilamelares de POPC/colesterol (4/1 en mol)- respectivamente 


\section{Estudios de estructura oligomérica usando agentes entrecruzantes (crosslinkers)}

Para muchas proteínas anfitrópicas, el mecanismo de interacción con la membrana depende de una modificación en su estructura cuaternaria. Es bien conocido que apoA-I en solución acuosa presenta un equilibrio entre la forma de monómero y de oligómeros de distinto número de agregación dependiendo de la concentración (McGuire et al., 1996). También es bien conocido que para formar complejos lipoproteicos discoidales se requiere de al menos una estructura dimérica, pero no existen datos disponibles sobre el estado oligomérico de apoA-I en el estado unido a membrana. Para estudiar los posibles cambios en la estructura oligomérica de apoA-I y AI 77-120 cuando se unen a vesículas fosfolipídicas, se usó un reactivo entrecruzante (crosslinker) capaz de unir covalentemente a los monómeros cercanos entre sí: Bissulfosuccinimidil suberato (BS3). Este reactivo divalente forma enlaces covalentes con aminas primarias, como los grupos amino de las proteínas, de manera de unir de manera irreversible los residuos de proteína que se encuentran dentro de una distancia de 8 átomos de carbono (McGuire et al., 1996).

ApoA-I y AI 77-120 (50 $\mu \mathrm{g})$ se trataron con BS3 en buffer fosfato sódico $25 \mathrm{mM}$ $\mathrm{pH} 7,8$; en ausencia y en presencia $(2 \mathrm{mg}$ ) de vesículas de POPC/Col (relación molar $4 / 1$ ) en un volumen final de $0,15 \mathrm{ml}$. En ausencia de vesículas, la relación molar entre reactivo y proteína o péptido es de 150/1, y en el caso de la reacción con vesículas dicha relación fue de 1500/1. Al cabo de tres horas a temperatura ambiente, las muestras se analizaron por SDS-PAGE en geles en gradiente ( 4 a 16\%) con buffer tris-glicina (en el caso de apoA-I), y geles al 16,5\% con buffer tris-tricina (para AI 77-120). 


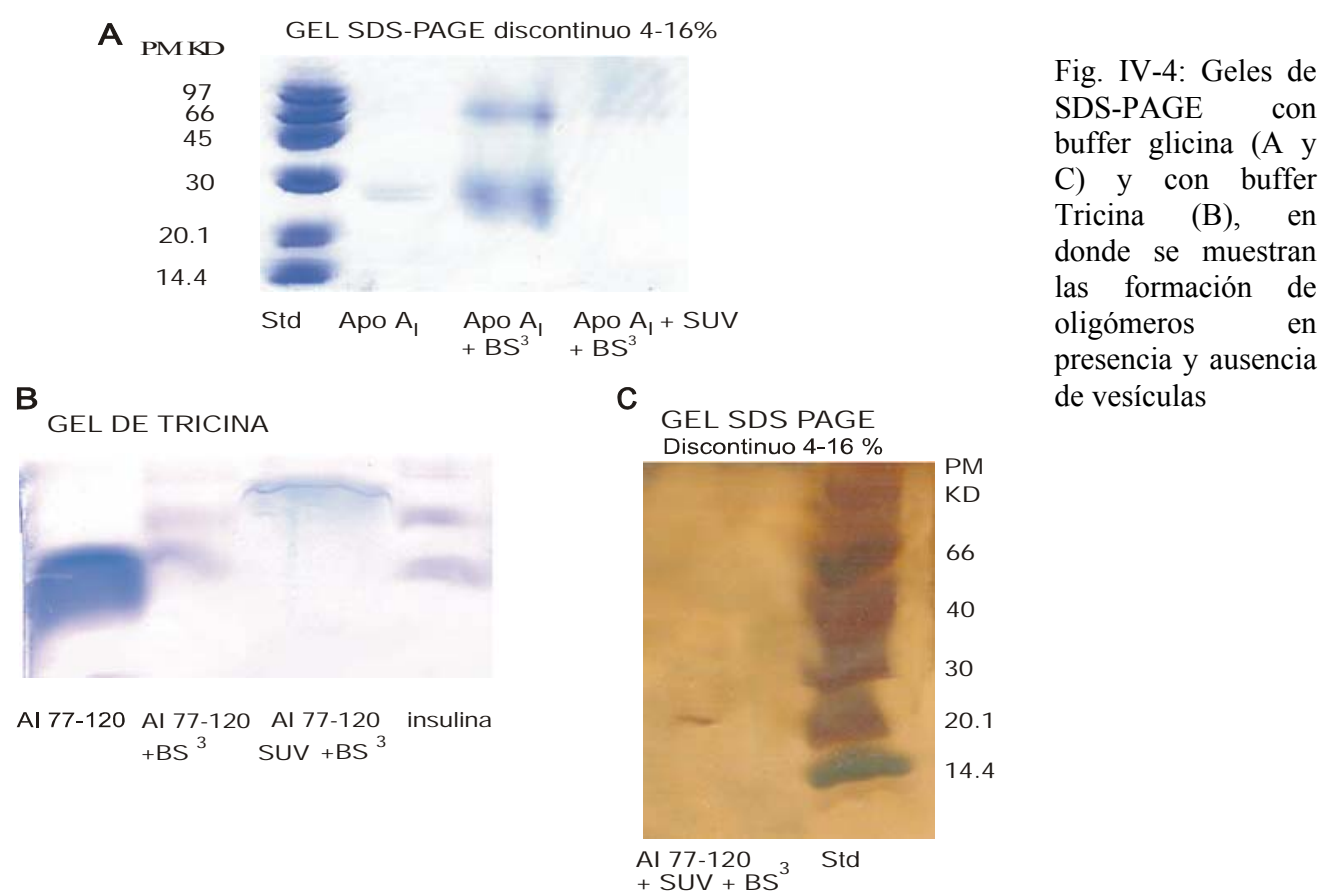

El entrecruzamiento por BS3 de apoA-I en solución acuosa (tercera calle de figura IV-4 A) indica que en la concentración ensayada, aproximadamente 2/3 de monómeros están en equilibrio con $1 / 3$ de dímeros. La adición de vesículas de POPC/colesterol (4/1) modifica esta distribución de modo que el monómero ya no se observa, el dímero llega ser la especie predominante y también se observan oligómeros mayores (trímeros y tetrámeros) en menores proporciones (Figura IV-4 A, calle 4).

La figura IV-4 B muestra los resultados del entrecruzamiento del péptido AI 77120 con el reactivo BS3. En solución acuosa y a la concentración ensayada (0.33 $\mathrm{mg} / \mathrm{ml}$ ), el monómero (aproximadamente $60 \%$ ) es la especie más abundante (segunda calle, en comparación con un estándar de insulina en la calle 4), seguida por el dímero (aproximadamente 30\%) y menores proporciones de oligómeros mayores. Similarmente a lo ocurrido con apoA-I, el agregado de vesículas fosfolipídicas resulta en la desaparición de la forma monomérica (tercera calle de Fig IV-4 B). El gel de poliacrilamida $16,5 \%$ con buffer tris-tricina mostrado en la figura IV-4 B es adecuado para separar péptidos pequeños, pero no permite distinguir bien si la forma más abundante de AI 77-120 en presencia de vesículas es trimérica o tetramérica. Para distinguir entre estas dos posibilidades, esta muestra también fue corrida en un gel en gradiente (4-16\%) con buffer tris-glicina (Fig IV-4 C). En el mismo se observa 
claramente que la banda principal tiene una masa aparente de $20 \mathrm{kD}$, que se corresponde con la forma tetramérica de AI 77-120.

Así, estos resultados indican que tanto apoA-I como AI 77-120 presentan una mayor tendencia a oligomerizar cuando se encuentran unidos a membrana en comparación a cuando están en solución acuosa.

\section{Capacidad de AI 77-120 para formar complejos lipoproteicos}

A) Mediante micelización a la temperatura de transición del lípido (Swaney and Chang, 1980)

Aunque apoA-I se une a vesículas de fosfolípidos zwitteriónicos en el estado líquido cristalino como POPC sin producir su disrupción, la interacción con vesículas de esta clase de lípidos en el rango de temperatura de la transición de fase gel/líquidocristalino (como DMPC a $24^{\circ} \mathrm{C}$ ) resulta en la rápida disrupción de las vesículas y la generación de HDL discoidales. Esta reacción de micelización es muy fácil de seguir por la disminución de turbidez. Se investigó la capacidad de AI 77-120 comparativamente con apoA-I para micelizar liposomas multilamelares de DMPC a $24^{\circ} \mathrm{C}$ midiendo el cambio de densidad óptica a $350 \mathrm{~nm}$. En la figura IV-5 se muestra que la reacción fue positiva para apoA-I pero completamente ineficiente para AI 77120.

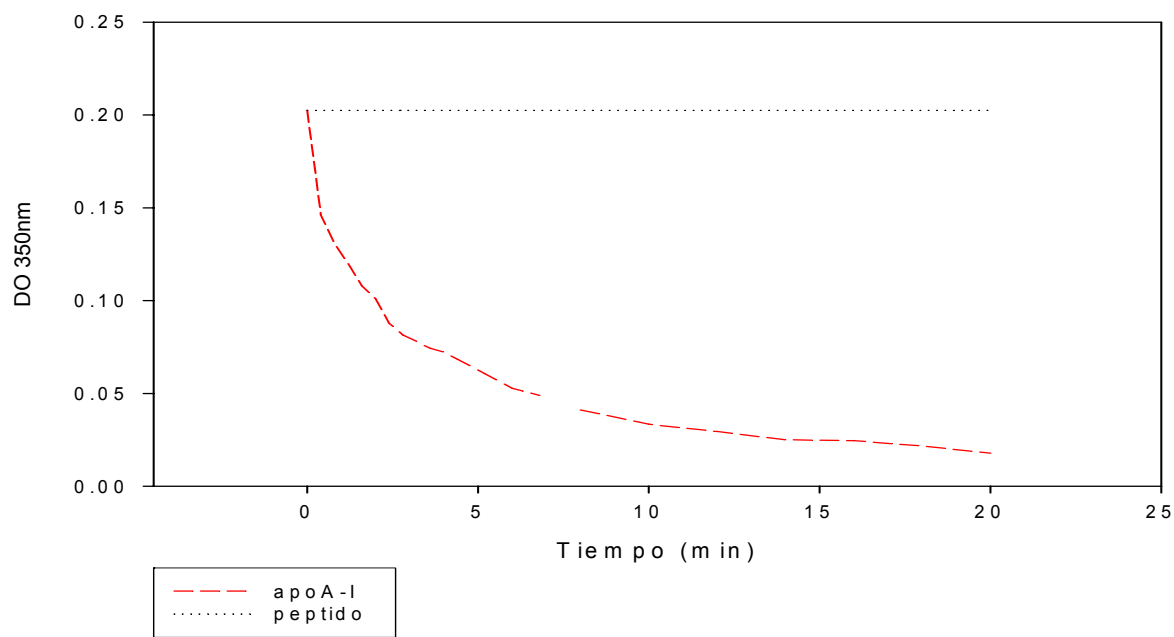

Fig.IV-5: Velocidad de micelización a temperatura de transición de fase de DMPC $\left(24^{0} \mathrm{C}\right)$ en presencia de apoA-I en rojo y del AI 77120 en negro. 
B) Mediante el uso del detergente colato de sodio

Complejos HDL discoidales de apoA-I con fosfolípidos también pueden ser obtenidos mediante la formación de micelas mixtas con el detergente colato de sodio, y la posterior eliminación del detergente por diálisis. Este método es muy utilizado para reconstituir HDL discoidales con fosfolípidos insaturados como POPC que presentan la transición de fase por debajo de $0^{\circ} \mathrm{C}$ (Matz and Jonas, 1982b),(Jonas et al., 1989). Se investigó la posibilidad de que AI 77-120 pudiera formar complejos lipoproteicos por este método. Para esto, se usaron membranas de diálisis de corte de $3.5 \mathrm{kD}$, a diferencia de las normalmente utilizadas con apoA-I (de $10 \mathrm{kD}$ ). En la figura IV-6 se muestra el análisis por PAGE nativo en gradiente $4-24 \%$ de los productos generados de esta manera por AI 77-120. Se observa claramente la generación de un complejo de alrededor de $70 \mathrm{kD}$.

Estos resultados indican que aunque AI 77-120 no reacciona espontáneamente con vesículas fosfolipídicas a la temperatura de transición, es capaz de formar complejos con lípidos con la ayuda de detergentes. Estos, sin embargo, son de bastante menor tamaño que las rHDL discoidales generadas por apoA-I (de al menos $100 \mathrm{kD}$ )

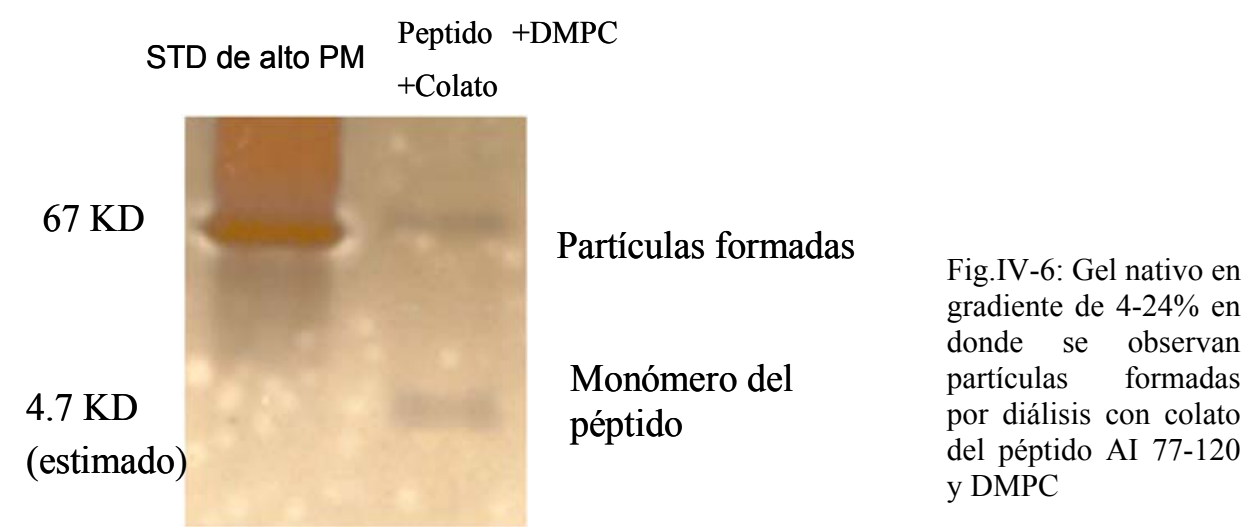




\section{Independencia funcional de AI 77-120. Catálisis de la transferencia de colesterol o su análogo dehidroergosterol entre vesículas fosfolipídicas}

Una propiedad de la apoA-I de gran relevancia para su rol en el transporte reverso de colesterol es su capacidad de facilitar la desorción de colesterol de membranas, catalizando así su transferencia a aceptores como lipoproteínas (Toledo et al., 2000) o vesículas lipídicas (Letizia and Phillips, 1991) Con el objeto de determinar si esta actividad de apoA-I es dependiente de la región central, se comparó la actividad de AI 77-120 con la de apoA-I completa para catalizar la transferencia de un análogo fluorescente de colesterol (dehidroergosterol, DHE) o colesterol radio marcado entre vesículas fosfolipídicas.

\section{Transferencia de dehidroergosterol entre vesículas}

El DHE tiene la propiedad de que su fluorescencia está autoextinguida si se encuentra en altas concentraciones en vesículas fosfolipídicas. Esto permite seguir la cinética de su transferencia a vesículas aceptoras por el incremento en la fluorescencia producido por la consecuente dilución. Se prepararon vesículas donoras con POPC y ergosta-5,7,9(11), 22-tetraen-3b-ol (dehidroergosterol, DHE) en relación molar 4/1. Las vesículas aceptoras se prepararon con $100 \%$ de POPC. Vesículas donoras (4 mM en POPC) se mezclaron con las aceptoras (100 $\mathrm{mM}$ en POPC) en ausencia o presencia de 5 $\mathrm{mM}$ de AI 77-120 o de apoA-I en 2,5 ml de buffer Tris- $\mathrm{HCl} 10 \mathrm{mM}, 150 \mathrm{mM}$ de $\mathrm{NaCl}$ $\mathrm{pH} 7.4$ a $30^{\circ} \mathrm{C}$. La reacción se siguió por el incremento en la fluorescencia (excitación $320 \mathrm{~nm}$ y emisión a $394 \mathrm{~nm}$, con $16 \mathrm{~nm}$ de ancho de banda en excitación y $8 \mathrm{~nm}$ en emisión) medida en un espectrofluorómetro SLM4800 con cubetas de $1 \mathrm{~cm}$ de paso óptico. Las velocidades iniciales de incremento de fluorescencia se muestran en la Figura IV-7 


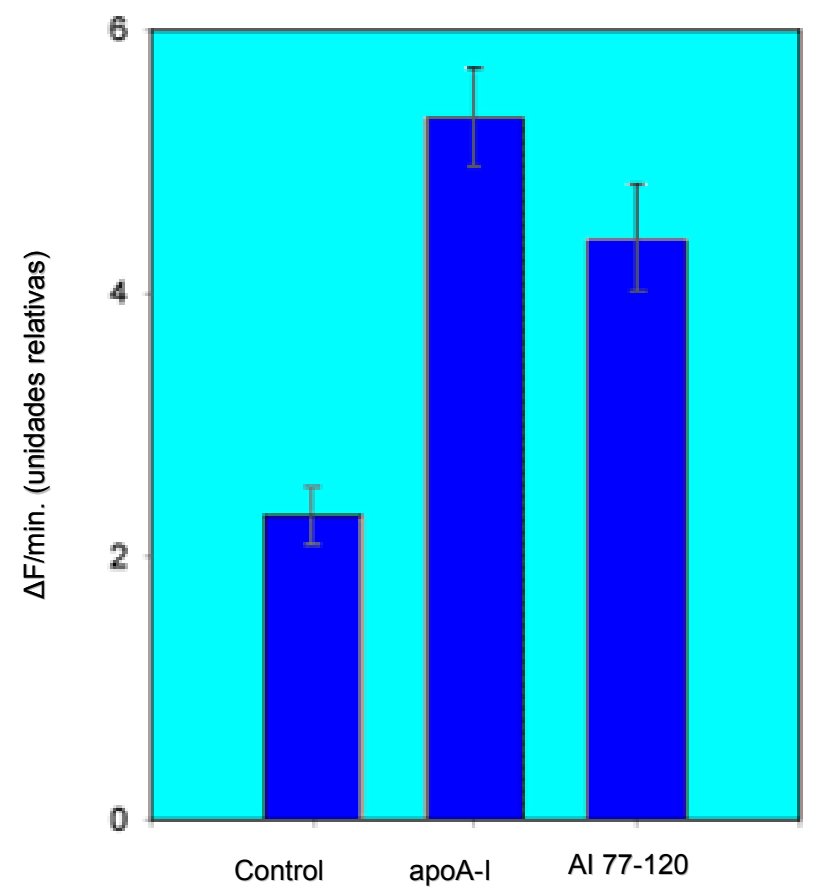

Fig IV-7: Actividad de AI 77-120 y de apoA-I para catalizar la transferencia de DHE entre vesículas: Vesículas donoras de (POPC/DHE 4:1 mol $/ \mathrm{mol})$ y aceptoras $(100 \%$ en POPC) son mezcladas como se indica más arriba. Las barras indican el incremento de fluorescencia inicial $(\Delta \mathrm{F} /$ minuto) de la dilución de DHE en ausencia (control) y en presencia de $5 \mu \mathrm{M}$ apoA-I o AI 77-120.

Estos datos indican que el péptido AI77-120 retiene casi completamente la actividad de apoA-I para catalizar la transferencia del DHE entre vesículas.

\section{Transferencia de ${ }^{3} \mathrm{H}$-colesterol desde vesículas de carga negativa a vesículas neutras}

Una segunda estrategia para evaluar comparativamente con apoA-I la actividad de AI 77-120 de catalizar la transferencia de colesterol entre vesículas fue la reportada por Letizia y Phillips (Letizia and Phillips, 1991) que se basa en medir la cantidad de colesterol radiomarcado transferido entre vesículas donoras y aceptoras de diferente carga para permitir su separación.

Las vesículas donoras (cargadas negativamente) se prepararon con una composición de $10 \%$ de colesterol, $75 \%$ POPC y $15 \%$ dicetil fosfato, conteniendo 2 $\mathrm{mCi} 3 \mathrm{H}-\mathrm{Col} / \mathrm{mg}$ de lípidos totales. Las vesículas aceptoras (neutras) tenían una composición de $10 \%$ colesterol, $90 \%$ POPC, y conteniendo 14C-trioleina $(0.05$ $\mathrm{mCi} / \mathrm{mg}$ de lípido) como un trazador no intercambiable. Las incubaciones se realizaron 
en fosfato de sodio $20 \mathrm{mM}$, pH 6 (buffer A) a $37{ }^{\circ} \mathrm{C}$, con una concentración de vesículas aceptoras diez veces en exceso con respecto a las donoras (concentración total $=0.45$ $\mathrm{mg} / \mathrm{ml}$ ), para que la etapa limitante sea la desorción del colesterol de éstas últimas, y minimizando así el flujo inverso. Alícuotas del medio de reacción fueron tomadas a diferentes tiempos y fraccionadas por intercambio iónico. Para esto, se prepararon pequeñas columnas de $1 \mathrm{ml}$ de capacidad con DEAE Sepharose CL-6B, equilibradas con buffer A y saturadas con vesículas sonicadas (unilamelares pequeñas) de PC de huevo para reducir adsorción inespecífica. Una alícuota de $0.25 \mathrm{ml}$ de la mezcla de reacción es cargada en la columna y eluída con $1 \mathrm{ml}$ de buffer A. El eluato es recogido y contado por centelleo líquido discriminando entre ${ }^{3} \mathrm{H}$ y ${ }^{14} \mathrm{C}$. La posibilidad de que apoA-I o AI 77-120 produzcan disrupción de las vesículas de carga negativa y/o generación de complejos lipoproteicos fue descartada por mediciones de turbidez (light scattering) y análisis por electroforesis en geles de poliacrilamida en condiciones no denaturalizantes.

La fracción de $3 \mathrm{H}-\mathrm{Col}$ transferido a las vesículas aceptoras se calculó de acuerdo a Letizia y Phillips (Letizia and Phillips, 1991) después de corregir por la recuperación de las vesículas aceptoras (obtenidas de las cuentas de 14C), y por la fracción de vesículas donoras que eluye de la columna (obtenida de la relación ${ }^{3} \mathrm{H} /{ }^{14} \mathrm{C}$ a tiempo cero). Los datos de la fracción transferida al aceptor $(\mathbf{X})$ en función del tiempo $(\mathbf{t})$ obtenidos se analizaron por regresión no lineal con la siguiente ecuación:

$$
\mathbf{X}=\mathbf{X m}(\mathbf{1}-\mathbf{e}-\mathbf{k t}) \quad(\text { ecuación } 2)
$$

El ajuste de esta ecuación a los datos experimentales permitió calcular la constante de transferencia de pseudo primer orden $(\mathbf{k})$ y la máxima fracción transferida a $t=\infty(\mathbf{X m})$. Como el valor de $\mathbf{X m}$ siempre estuvo comprendido entre 0,4 y 0,5; el mismo se fijó en 0,455 para aumentar la precisión en el cálculo de $\mathbf{k}$. Este valor fue asumido considerando que las vesículas aceptoras se encuentran diez veces más concentradas que las donoras, y que sólo el colesterol de la hemicapa externa (un 50\%) es transferido. 


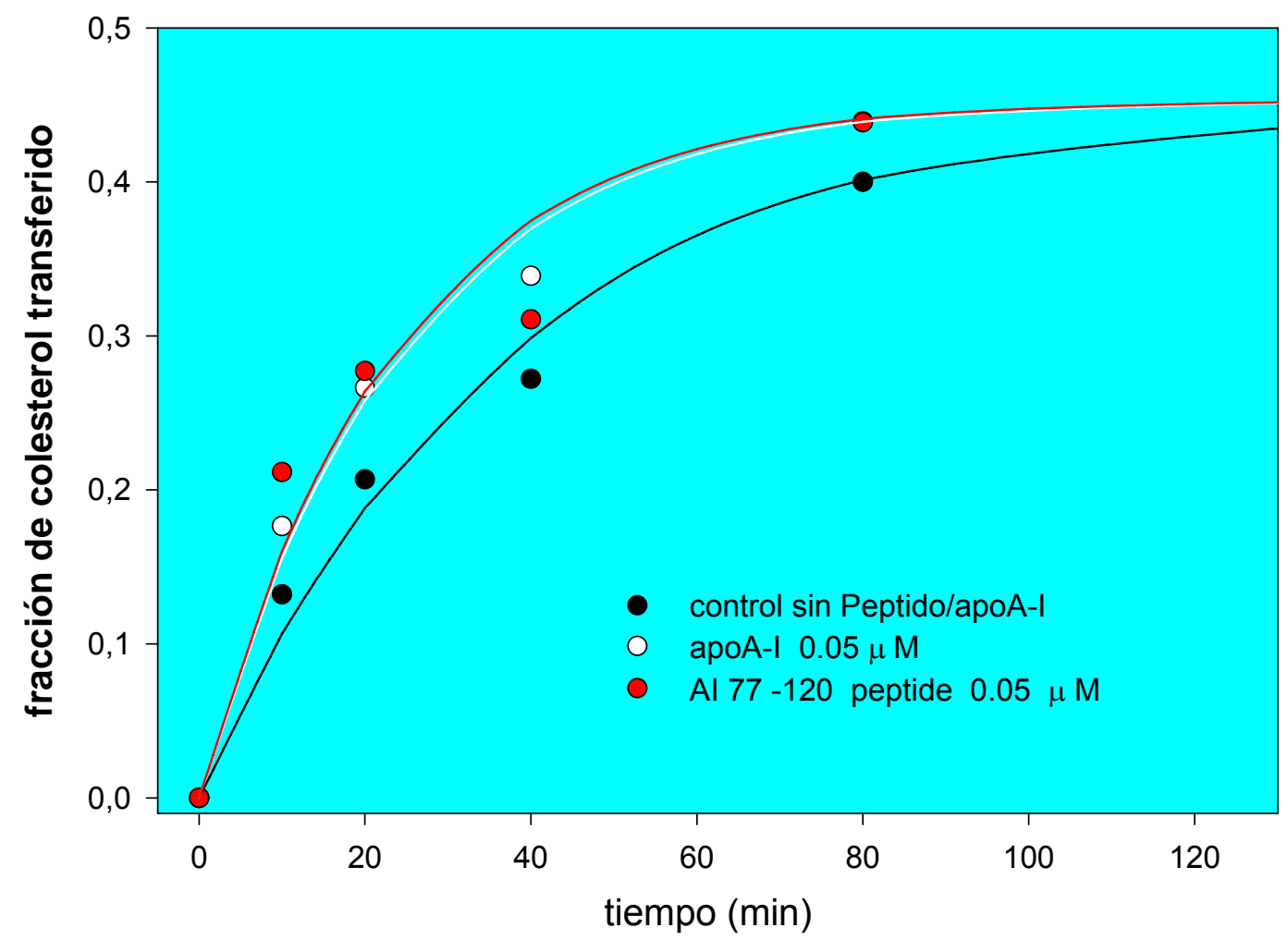

Fig. IV-8: Influencia de apoA-I y de AI 77-120 sobre la velocidad de desorción de colesterol desde vesículas de carga negativa y su transferencia a vesículas neutras. Las líneas los mejores ajustes de la ecuación 2 a los datos.

La figura IV-816 muestra que similarmente a apoA-I, el péptido AI 77-120 incrementa la velocidad de transferencia de colesterol entre estas vesículas. La relación exponencial simple asumida (ecuación 2) se ajusta bien a los datos obtenidos. Se realizaron mediciones con diferentes concentraciones de AI 77-120 o apoA-I. Los valores de la constante de velocidad $\mathbf{k}$ obtenidos de los ajustes son graficados en la figura IV-9, que indica una dependencia hiperbólica.

Como fue bien discutido por Letizia y Phillips (Letizia and Phillips, 1991), con este exceso de vesículas aceptoras la etapa limitante es la desorción del colesterol de la bicapa de las vesículas donoras. Así, estos resultados muestran que AI 77-120 tiene una actividad similar a la apoA-I completa para facilitar la desorción de colesterol de membranas y sugieren que el dominio central de apoA-I sería responsable de esta propiedad. 


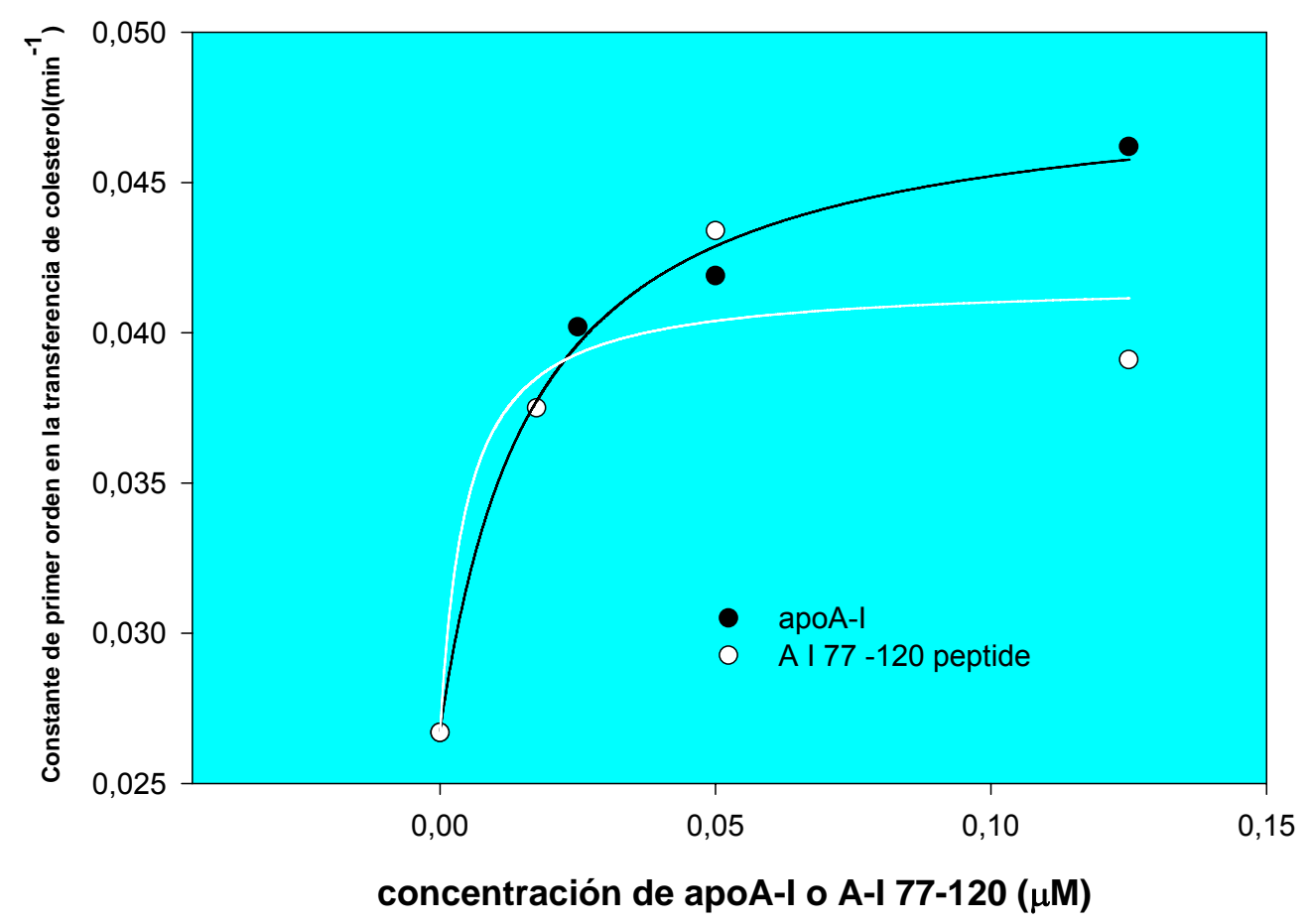

Fig.IV-9: Dependencia de la concentración sobre la transferencia de colesterol activada por apoA-I o AI77-120

\section{Conclusiones parciales}

Los resultados de los experimentos descriptos en esta parte del trabajo soportan la hipótesis de que la región de apoA-I que incluye al par de hélices Y 3-4 constituye un dominio estructural y funcionalmente independiente del resto de la proteína. Esta región aislada (en el péptido AI 77-120) es capaz de mantener varias de las propiedades que presenta la proteína completa como: a) interactuar preferentemente con membranas que contienen colesterol, b) insertarse profundamente en la bicapa lipídica, y c) promover la desorción de colesterol de membranas y facilitar su transferencia a vesículas aceptoras.

AI 77-120 presenta un contenido de $\alpha$-hélice considerable para un péptido de su tamaño, el que no parece modificarse en la interacción con la membrana. Sin embargo, la inserción en la membrana va acompañada de oligomerización. Este hecho, que también se demostró aquí que ocurre con apoA-I completa, es de gran importancia para considerar el mecanismo de inserción del dominio central en la membrana. La oligomerización de AI 77-120 en la membrana podría permitir la formación de un ramillete de hélices intermolecular (como en ectatomin) que se inserten en la bicapa 
lipídica con el eje mayor de las hélices perpendicular a la superficie de la membrana. El hecho de que también se observe para apoA-I una mayor eficiencia de oligomerización cuando unida a vesículas, nos permitió expandir la hipótesis y postular que el dominio de inserción activo podría ser un ramillete intermolecular formado por dos pares de hélices Y centrales.

Es claro y esperable que no todas las propiedades de apoA-I dependan de su región central y puedan ser reproducidas por AI 77-120. Entre las que no pueden ser reproducidas, se determinó aquí la incapacidad de AI 77-120 para generar espontáneamente complejos lipoproteicos por su interacción con vesículas de DMPC a la temperatura de transición. Esto podría deberse a pequeño tamaño o a su relativamente baja afinidad por membranas que carecen de colesterol. Al respecto, es de notar que otros fragmentos de apoA-I como aquel conteniendo al par de hélices Y del extremo C presentan una afinidad por lípidos mucho mayor y producen la disrupción de vesículas de DMPC a la temperatura de transición (Palgunachari et al., 1996). Aunque incapaz de micelizar vesículas de DMPC, AI 77-120 puede formar complejos con lípidos de unos $70 \mathrm{kDa}$ por diálisis de micelas mixtas con detergentes.

El par de hélices Y centrales aisladas parecen ser bastante estable en solución acuosa, como lo indica el hecho de que AI 77-120 sea mayoritariamente monomérica en concentraciones tan altas como $0,33 \mathrm{mg} / \mathrm{ml}$. o $66 \mu \mathrm{M}$ (como para apoA-I la misma concentración en peso es unas 6 veces menor en moles, es claro que ésta tiene una mayor tendencia a oligomerizar en solución acuosa que AI 77-120). Ya que un factor importante que favorece la tendencia a oligomerizar es la exposición al entorno acuoso de regiones (patchs) hidrofóbicas, la relativamente alta estabilidad de AI 77-120 en forma monomérica podría ser explicada por el mayor ancho de las caras hidrofílicas respecto a las hidrofóbicas que presentan estas hélices (ver Sección Objetivos). Esto permitiría la interacción de estas dos hélices por sus caras hidrofóbicas resulte en la casi nula exposición de residuos hidrofóbicos al entorno acuoso. 
Parte B

Estudios de Resonancia de Electrónica Paramagnética 


\section{Estudios de Resonancia de Electrónica Paramagnética}

Estos estudios tuvieron la finalidad de determinar cómo es modificada la movilidad y orden de las cadenas hidrocarbonadas de los lípidos a diferentes profundidades de la bicapa lipídica cuando la apoA-I o el péptido AI 77-120 interaccionan con membranas, y cómo se ven afectadas las diferentes regiones de una bicapa lipídica que forma parte de complejos discoidales con la apoA-I. El parámetro utilizado para cuantificar la movilidad es el denominado parámetro de orden (ver Métodos), que no está relacionado con la velocidad de movimiento sino con la restricción de las posibles orientaciones que pueda adquirir la sonda paramagnética. Cuanto mayor es el parámetro de orden, menor es el ángulo cónico dentro del que está restringida la movilidad de la sonda.

\section{Influencia de la unión de apoA-I y AI 77-120 a vesículas fosfolipídicas sobre la movilidad de los lípidos de la membrana}

Se realizaron estudios utilizando como modelos de membranas vesículas unilamelares de POPC o POPC/Col, con la cantidad adecuada de marcador de espin (ver métodos). El motivo de utilizar estos dos tipos de membrana es que, si bien tanto la apoA-I como el péptido se unen con cierta afinidad a membranas de POPC pura, ambos interactúan con mayor afinidad a bicapas que contienen colesterol. Se trabajó a una relación molar lípido/proteína de 15/1 (en la que las vesículas se encontrarían saturadas con apoA-I o AI 77-120), y a diferentes temperaturas obteniéndose los siguientes resultados con los diferentes marcadores de espin. A continuación se muestran los espectros de EPR realizados obtenidos con vesículas de POPC/Colesterol 


\section{Proteína}

Tempo-Pc

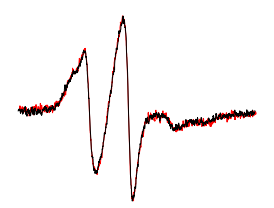

Péptido

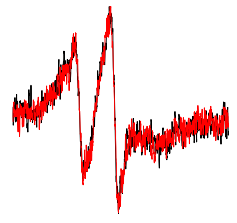

5-Doxil-PC
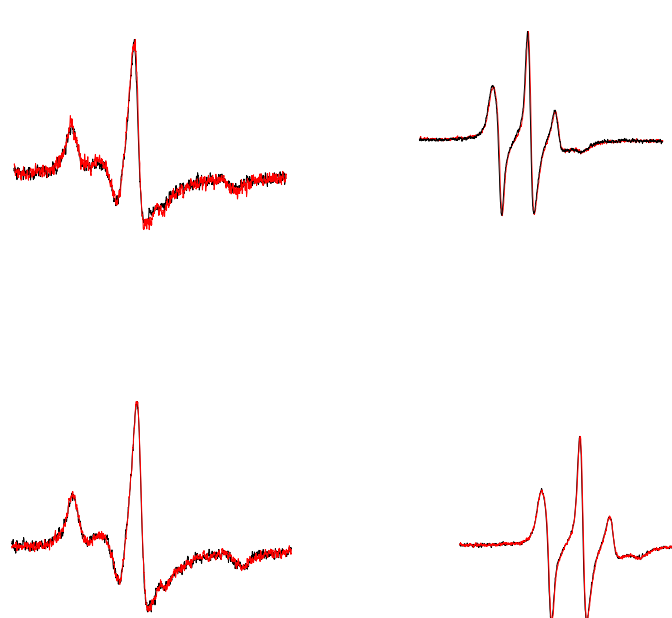

16-Doxil-PC

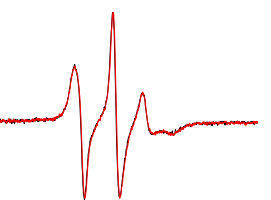

Fig. IV-10(a)

$5^{0} \mathrm{C}$

Fig.IV-10: Espectros de EPR con campo de barrido de 100gaus de vesículas de POPC/Col (4/1 en mol) solas (líneas negras) o con el agregado de apoA-I o AI 77-120 a una relación molar lip/rot. de 15/1. Las temperaturas analizadas fueron 5 (a), 25 (b) y 37 (c) ${ }^{0} \mathrm{C}$

\section{Proteína}

Tempo-Pc

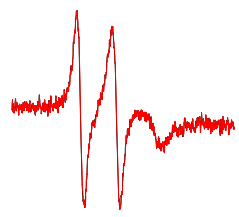

5-Doxil-PC

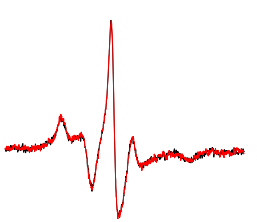

16-Doxil-PC

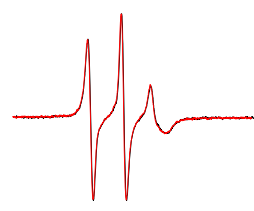

Péptido

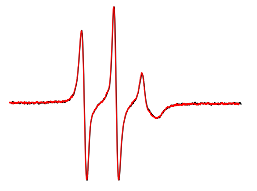

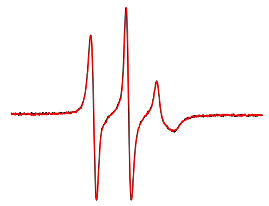

Fig. IV-10(b)

$25^{0} \mathrm{C}$ 
Proteína:

Tempo-Pc

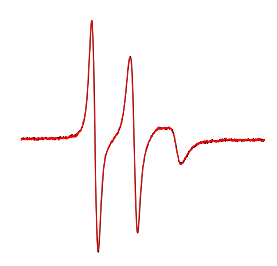

Péptido

Fig. IV-10(c)

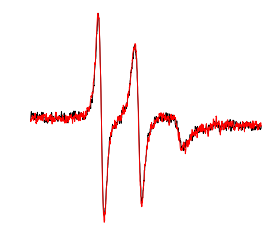

5-Doxil-PC
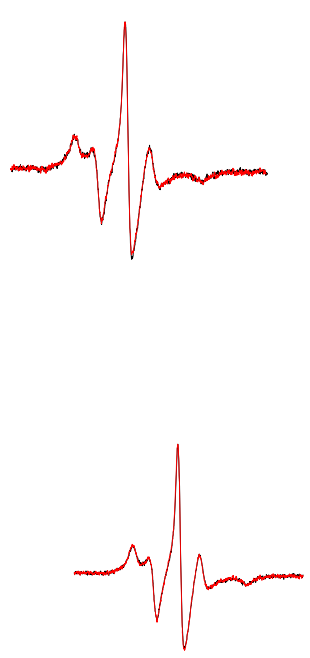

16-Doxil-PC
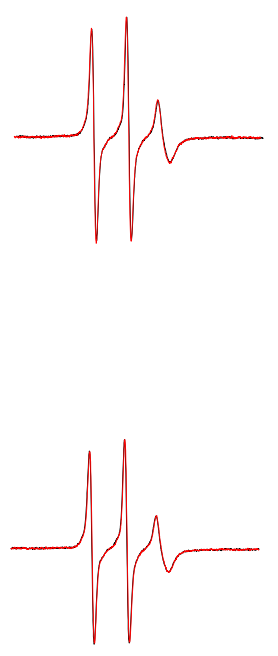

$37^{0} \mathrm{C}$

Como se puede observar en los gráficos, los espectros de Tempo-PC, 5-doxil-PC y 16-doxil-PC en vesículas de POPC/colesterol (4/1 en mol) difieren entre sí y son modificados por la temperatura, pero en ningún caso se observa alguna influencia de apoA-I o AI 77-120. Las mismas mediciones fueron realizadas en vesículas de 100\% POPC (datos no mostrados). Si bien los espectros difieren de los obtenidos en presencia de colesterol, en ningún caso se observó algún efecto de apoA-I o AI 77-120.

Dado que tanto apoA-I como AI 77-120 poseen mayor afinidad por vesículas con colesterol, fue de interés determinar si éstos podían tener alguna influencia sobre los espectros de un análogo de colesterol, el 3- $\beta$-Doxil- Colestano (CSL, cholesterol spin label). Como ocurrió en las mediciones anteriores, no fue posible detectar cambios en el espectro de CSL mediante este experimento (Figura IV11).

CSL-POPC/COL rela. lip/prot y lip/ peptido 15/1 (5 grados)

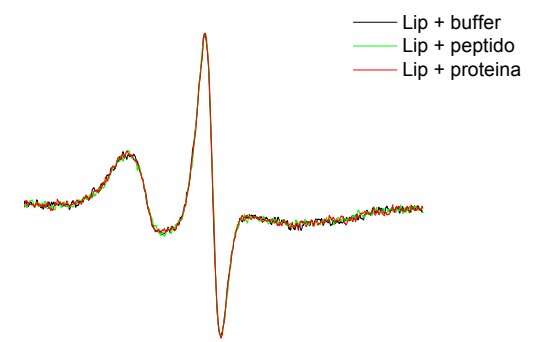

CSL-POPC/COL rela. lip/prot y lip/ peptido 15/1 (37 grados)

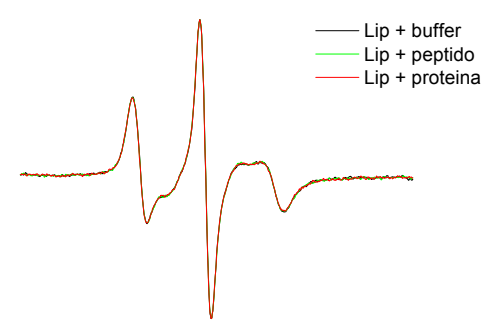

Fig.IV-11: espectros de EPR, (campo barrido de 100 gaus) analizando la interacción de apoA-I y AI 77-120 con vesículas de POPC:col que poseen el 3- $\beta$-Doxil- Colestano 
La figura IV-11 muestra que tampoco en este caso hubo algún efecto detectable ni a $5^{\circ} \mathrm{C}$ ni a $37^{\circ} \mathrm{C}$.

Las figuras IV-11 y IV-12 indican que la interacción de apoA-I o AI 77-120 con membranas fosfolipídicas no es detectable con las sondas utilizadas. Por lo inesperado de estos resultados, la preparación de apoA-I utilizada en estos experimentos fue ensayada en su actividad para micelizar liposomas multilamelares de DMPC, teniendo una actividad normal en dicho ensayo. Algunas de las mediciones de EPR fueron confirmadas con una segunda preparación de apoA-I proveniente de otro stock de suero.

La posibilidad de que las sondas paramagnéticas en la membrana de las vesículas puedan alterar de alguna manera su estructura y por lo tanto la unión de apoAI puede ser totalmente descartada, ya que éstas se usan en muy pequeñas proporciones, y como se verá más adelante, las mismas sondas fueron utilizadas en concentraciones muy superiores como extinguidores de la fluorescencia de triptofano de mutantes de apoA-I con resultados positivos. Así, se debe concluir que la interacción de apoA-I y AI 77-120 con vesículas de POPC o POPC/colesterol (4/1 en mol) se produce de tal manera que no afecta a la movilidad promedio de los lípidos del entorno. Esta conclusión también es soportada por mediciones de polarización generalizada de la fluorescencia del Laurdan (una sonda sensible al grado de empaquetamiento de los lípidos en la bicapa lipídica) con la que tampoco se detectó algún efecto de apoA-I (resultados no mostrados).

\section{Mediciones del ordenamiento de los lípidos en complejos lipoproteicos de apoA-I con DMPC generados por la micelización de vesículas en la transición de fase}

Mediante el empleo de los marcadores de spin mencionados anteriormente se intentó medir la cinética de formación de discos agregando apoA-I a vesículas de DMPC en la temperatura de transición de fase $\left(24^{\circ} \mathrm{C}\right)$; estos espectros no fueron óptimos debido a que la velocidad de barrido del campo es menor a la de la cinética de micelización y por lo tanto la movilidad de los lípidos y los correspondientes marcadores se alteraba a medida que ocurría el proceso. Para evitar este inconveniente, se dejó la mezcla de incubación hasta completar la reacción. Una vez formados los discos, se los dejó a temperatura ambiente $\left(25^{\circ} \mathrm{C}\right)$ por 24 horas y se realizaron las medidas a cuatro temperaturas diferentes: dos por debajo de la temperatura de transición de fase $\left(5\right.$ y $\left.10{ }^{0} \mathrm{C}\right)$, a la temperatura de transición $\left(24^{\circ} \mathrm{C}\right)$ y otra por encima de ella, 
precisamente a $37^{\circ} \mathrm{C}$. Se comparó el valor del parámetro de orden obtenido para cada sonda en los complejos discoidales, SP (parámetro de orden de complejos lipoproteicos) respecto al obtenido en vesículas multilamelares de DMPC SB1 (parámetro de orden de marcadores en las vesículas multilamelares utilizadas de blanco). Los resultados se resumen en la siguiente tabla como relación $\mathrm{SP} / \mathrm{SB} 1$ :

\begin{tabular}{|c|c|c|c|}
\hline \multirow{2}{*}{ Temperatura $\left({ }^{\mathbf{0}} \mathbf{C}\right)$} & Tempo & $\mathbf{5 - P c}$ & $\mathbf{1 6 - P c}$ \\
\cline { 2 - 4 } & SP/SBI & SP/SBI & SP/SBI \\
\hline $\mathbf{5}$ & 1.01 & 0.99 & 0.94 \\
\hline $\mathbf{1 0}$ & 1.02 & 0.81 & 0.95 \\
\hline $\mathbf{2 4}$ & 0.96 & 1.14 & 1.16 \\
\hline $\mathbf{3 7}$ & 0.94 & 1.11 & 1.08 \\
\hline
\end{tabular}

Estos resultados indican que el ordenamiento de las cadenas hidrocarbonadas de los fosfolípidos es diferente en los discos con apoA-I que en las vesículas multilamelares. Por debajo de $24{ }^{\circ} \mathrm{C}$, la DMPC se encuentra en fase gel. En estas condiciones, las regiones monitoreadas por los marcadores de spin 5-Doxil- PC y 16Doxil-PC están menos ordenadas o más fluidas en los discos que en las vesículas multilamelares. Por encima de $24{ }^{0} \mathrm{C}$, los marcadores 5-PCSL y 16-PCSL informan que la región de bicapa lipídica monitoreada está más rígida (menor movilidad y/o mayor orden) en los discos que en las vesículas. En cambio, a estas temperaturas, la región fosfolipídica de la cabeza polar, monitoreada por Tempo-PC se muestra algo más fluida (mayor movilidad y/o menor orden) que en las vesículas. En trabajos anteriores, Jonas y colaboradores estudiaron partículas similares (aunque reconstituidas por por el método de diálisis con colato), midiendo movilidad de las cadenas acílicas mediante polarización con difenilhexatrieno (DPH), y el grado de hidratación de la superficie mediante el corrimiento de la emisión de fluorescencia de la sonda PRODAN. Ellos definen que, a $37^{\circ} \mathrm{C}$, la DMPC se encuentra áltamente empaquetada en estas partículas (Jonas et al., 1987). Asumiendo que la vesícula puede ser tomada como referencia de las bicapa lipídica de los discos en ausencia de proteína, el efecto observado (para la apoAI) es semejante al encontrado para moléculas que intercalan entre las cadenas hidrocarbonadas, como ser el colesterol. Generalmente, estas por un lado dificultan el empaquetamiento de las cadenas hidrocarbonadas en el estado gel disminuyendo su ordenamiento, y por otro lado restringen la libre movilidad incrementando el ordenamiento de las cadenas hidrocarbonadas en el estado fluido. 
De acuerdo con los modelos de los complejos discoidales, la apoA-I se dispone en el borde del disco con las hélices anfipáticas "protegiendo" a las cadenas hidrocarbonadas de su exposición al medio acuoso, por lo que es razonable asumir una intercalación de la misma entre las cadenas hidrocarbonadas de los fosfolípidos. Aún con la proteína en el borde del disco, un gran porcentaje de los lípidos sería directamente afectado, por lo que el efecto resultante sería similar al producido por la intercalación. Estos discos contienen alrededor de 120 moléculas de DMPC (60 en cada monocapa) y dos moléculas de apoA-I. Asumiendo un empaquetamiento hexagonal, unas 24 moléculas de DMPC (40\%) se localizarán en el borde de cada hemicapa interactuando directamente con las caras hidrofóbicas de las hélices de apoA-I. Los grupos hidrofóbicos de los aminoácidos de la cara no polar de las hélices quedarían intercalados entre las cadenas hidrocarbonadas de los fosfolípidos localizados en el borde restringiendo su movilidad en el estado fluido e impidiendo su empaquetamiento ordenado en la fase gel. Si la influencia de la proteína se extendiera al segundo anillo de lípidos más cercanos, el porcentaje de lípidos afectados alcanzaría al 70\%.

Esta interacción de las caras hidrofóbicas de las hélices con las cadenas hidrocarbonadas de los fosfolípidos del borde del disco debería ser muy ajustada para evitar la entrada de agua o la exposición al agua de restos hidrofóbicos. El resultado de la misma es que en el estado fluido, el cinturón de hélices de apoA-I "aprieta" a la región de las cadenas hidrocarbonadas restringiendo su movilidad, dejando relativamente "suelta" a la región de los grupos polares. Por debajo de $24{ }^{\circ} \mathrm{C}$, el cinturón de apoA-I actuaría de modo inverso, impidiendo el estrecho empaquetamiento de las cadenas hidrocarbonadas pero sin afectar mayormente al ordenamiento en la región de los grupos polares. Esto podría deberse a que la intercalación de los restos de aminoácidos hidrofóbicos entre las cadenas hidrocarbonadas de los lípidos del borde dificulta su empaquetamiento. Además, si el cinturón proteico es relativamente rígido también podría dificultar la contracción y compactación de los lípidos en la fase gel. En ausencia de alguna restricción impuesta por la proteína, la superficie del disco lipídico se reduciría de unos 54 a unos $30 \mathrm{~nm}^{2}$ al pasar del estado fluido al estado gel (se asume 0,7 y $0,5 \mathrm{~nm}^{2} /$ molécula en estado fluido y gel respectivamente). Puede estimarse que el diámetro del disco lipídico se reduciría cerca del 20\% en ese proceso. En presencia de un cinturón de hélices rígido, el disco lipídico no podría contraerse libremente ya que su separación del cinturón es energéticamente desfavorable y dejaría un espacio libre para la entrada de agua, por lo que los lípidos no podrían adquirir el estado altamente 
compactado y ordenado de la fase gel que presentan en las vesículas de DMPC pura. Así, la influencia de un cinturón proteico rígido sobre las propiedades de los lípidos del disco puede ser muy similar a la producida por compuestos que se intercalan en la bicapa lipídica como el colesterol.

Es de notar que la transición de fase de la DMPC en los discos es menos abrupta que en vesículas multilamelares, pero no desaparece completamente como ocurre en vesículas con muy alto contenido de colesterol. En realidad, los cambios en los parámetros de orden en relación a las vesículas de DMPC pura no son tan grandes como podría esperarse de las consideraciones anteriores ya que no superan el $20 \%$ (ver tabla), por lo que aún debería ocurrir un cambio importante en el área ocupada por la DMPC en los discos durante la transición. Por la gran flexibilidad conformacional que presentan las apolipoproteínas intercambiables como apoA-I, es razonable suponer que el "cinturón" de hélices en el borde del disco no sea totalmente rígido y que pueda adaptarse al menos parcialmente al cambio de la superficie de la bicapa lipídica. Aunque no hay datos al respecto, se podría especular sobre dos posibles modos de adaptación: a) La reducción de superficie ocupada por los lípidos podría ocurrir sin cambios en el perímetro si un disco circular se transforma en uno de forma oval, y b) De mantenerse la forma circular, el cinturón proteico podría adaptarse a los cambios de perímetro cambiando el número de hélices en contacto con el borde del disco como ha sido propuesto para HDL discoidales con diferente cantidad de lípidos (ver Introducción). 
Parte C

Estudios con mutantes de apoA-I con un único residuo de triptofano (Trp) 


\section{Estudios con mutantes de apoA-I con un único residuo de triptofano (Trp)}

El tercer objetivo de este trabajo fue la construcción de una serie de mutantes de apoA-I conteniendo un único residuo Trp en diferentes posiciones de sus hélices Y centrales, para estudiar con ellos la conformación de esta región y su mecanismo de inserción en membranas. Las propiedades de fluorescencia de cada mutante informan sobre el entorno de cada una de las posiciones reportadas por el correspondiente Trp.

En principio nos propusimos la obtención de seis mutantes con un único Trp en cada una de las posiciones ocupadas por un residuo hidrofóbico en la región candidata a insertarse en la membrana (posiciones 90, 93, 97, 101, 104 y 108). Estas son denominadas respectivamente W@90,W@93,W@97,W@101,W@104y W@108. Como control de fluorescencia inespecífica se utilizó la mutante W@0, en la que los cuatro residuos Trp de la proteína madura (en las posiciones 8, 50, 72 y 108) fueron reemplazados por fenilalanina.

\section{Mutagénesis sitio-dirigida para la obtención de las mutantes de apoA-I de Trp único}

Como se mencionó en la sección Materiales y Métodos, la construcción de los cDNA mutantes de realizó por mutagénesis sitio dirigida usando el kit "Quick-Change" de Stratagen a partir del mutante W@0. El plásmido más el inserto de pre proapoA-I tiene una extensión de 6500 pares de bases.

Las secuencias diseñadas de oligonucleótidos iniciadores fueron las siguientes:

Leu 90 a Trp

Primer 1: 5'-G GAG ATG AGC AAG GAT TGG GAG GAG GTC AAG GCC-3' Primer 1': $3^{\prime}-\mathrm{C}$ CTC TAC TCG TTC CTA ACC CTC CTC CAG TTC CGG-5'

$\underline{\text { Val } 93 \text { a Trp }}$

Primer 2: 5'-GCC AAG GAT CTG GAG GAG TGG AAG GCC AAG GTG C- 3' Primer 2': 3'-CGG TTC CTA GAC CTC CTC ACC TTC CGG TTC CAC G-5'

Val 97 a Trp

Primer 3: 5' - G GAG GTG AAG GCC AAG TGG CAGCCC TAC CTG GAC G- 3

Primer $3^{\prime}: 3^{\prime}$.- C CTC CAC TTC CGG TTC ACC GTC GGG ATG GAC CTG C-5'

Leu 101 a Trp

Primer 4: 5'- GCC AAG GTG CAG CCC TAC TGG GAC GAC TTC CAG- 3'

Primer 4': 3'- CGG TTC CAC GTC GGG ATG ACC CTG CTG AAG GTC-5'

Phe104 a Trp

Primer 5 : 5' - CC TAC CTG GAC GAC TGG CAG AAG AAG TTC CAG G-3'

Primer 5': 3'- GG ATG GAC CTG CTG ACC GTC TTC TTC AAG GTC C-5'

Phe108 a Trp

Primer 6: 5'- C TTC CAG AAA AAG TGG CAG GAG GAG ATG G -3'

Primer 6': 3'- G AAG GTC TTT TTC ACC GTC CTC CTC TAC C - 5' 
Estos Primer fueron sintetizados en el Department of Biochemistry and Molecular Biology, Oklahoma State University, Stillwater, OK, USA

En primera instancia, se logró obtener con éxito la mutación en la posición 108 (W@108). La obtención de las restantes mutaciones se vio demorada por desperfectos en el equipamiento del instituto, pero luego se adquirió un equipo nuevo de ciclación y se volvió a poner a punto las reacciones de PCR. Esta etapa no fue sencilla, debido a que por diferentes causas las reacciones no poseían la misma eficiencia para todas las mutaciones deseadas, por lo que se buscaron las condiciones de amplificación para cada una de ellas.
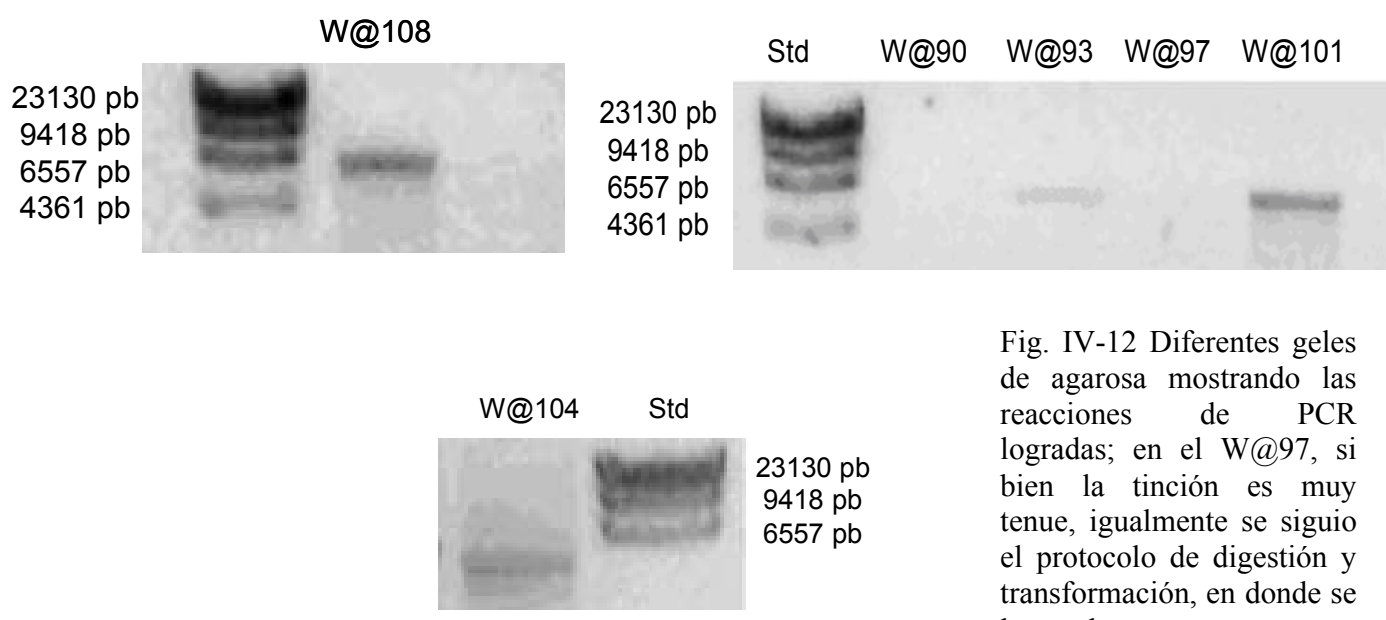

Fig. IV-12 Diferentes geles de agarosa mostrando las reacciones de PCR logradas; en el W@97, si bien la tinción es muy tenue, igualmente se siguio el protocolo de digestión y transformación, en donde se logro el mutante.

\section{Expresión, purificación y clivaje de las proteínas de fusión de los mutantes anteriores}

Se utilizaron en una primera instancia, los plásmidos conteniendo los insertos de cDNA de las formas pro-apoA-I, W@0 y W@108 para transformar mediante shock térmico bacterias de expresión (BL21). Se verificó con cultivos en pequeña escala (4 ml de medio de cultivo) que las bacterias BL21 transformadas expresaran las respectivas proteínas al ser inducidas con IPTG, para luego pasar a expresar en mayor cantidad (1 litro de medio de cultivo); así se logró, de estas proteínas recombinantes un rendimiento aproximado de $15 \mathrm{mg}$ de proteína purificada/l. 


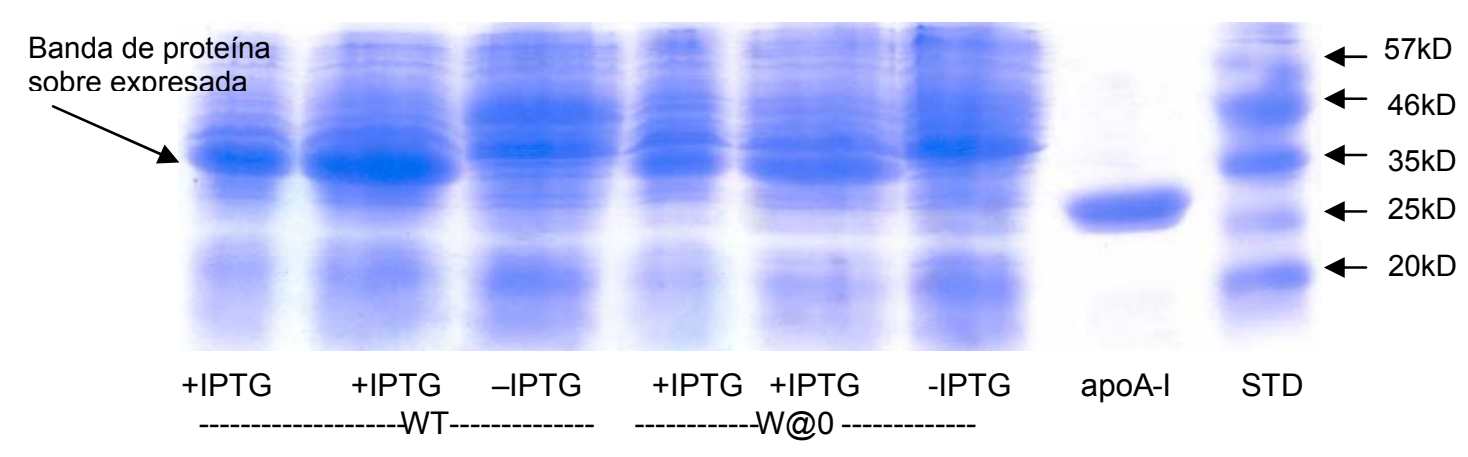

Fig.IV-13: En las figuras se muestran dos geles de SDS PAGE de proteínas totales de bacterias inducidas y no inducidas con IPTG

Estos pasos se repitieron con los mutantes W@93,W@101,W@104,y W@108 cuyas secuencias fueron confirmadas. En el caso de W@101, no se observó expresión a pequeña escala, esto puede ser debido a la toxicidad del mutante en cuestión, aunque no puede descartarse una mutación en el promotor u otro sitio del plásmidos que no afecte a la secuencia de la proteína, pero que disminuya la expresión. Por ello, se intentó igualmente en numerosas ocasiones y con distintas condiciones pasar a la expresión a gran escala. Se optó como protocolo la obtención de biomasa, (crecimiento hasta una $\mathrm{DO}_{650}$ cercano a uno), e inducción con IPTG. En este punto el crecimiento bacteriano se detiene, y los recursos del medio de cultivo son derivados a la obtención de proteínas. Este cambio de estrategia se usó para las mutantes W@97 y W@104, obteniéndose un rendimiento de 2-5 mg por litro de medio, pero siguió siendo negativo para el 101 .

Las proteínas expresadas fueron purificadas por cromatografía de afinidad con metales inmovilizados (IMAC) como se menciona en materiales y métodos. Para esto se usaron columnas con una matriz conteniendo $\mathrm{ZnCl}_{2}$ (Boehringer) ó $\mathrm{NiSO} 4$, a las que las proteínas con cola de histidina se adsorben por afinidad. Las proteínas contaminantes se lavan, primero con buffer fosfato, luego con el mismo buffer con baja concentración de imidazol y finalmente se eluyen las proteínas de interés mediante competencia con buffer conteniendo $0,5 \mathrm{M}$ de imidazol. Se siguió la elusión por Absorbancia 280nm cada $2 \mathrm{ml}$ de eluido y la pureza de éstos se controló por SDS-PAGE. El rendimiento promedio obtenido fue apropiado, y dependiendo de la mutante en cuestión, del orden de 10-15 mg por litro de medio. La figura IV-14 muestra un perfil de elución típico durante los pasos de purificación, y la figura IV-15 la pureza de la preparación final. 


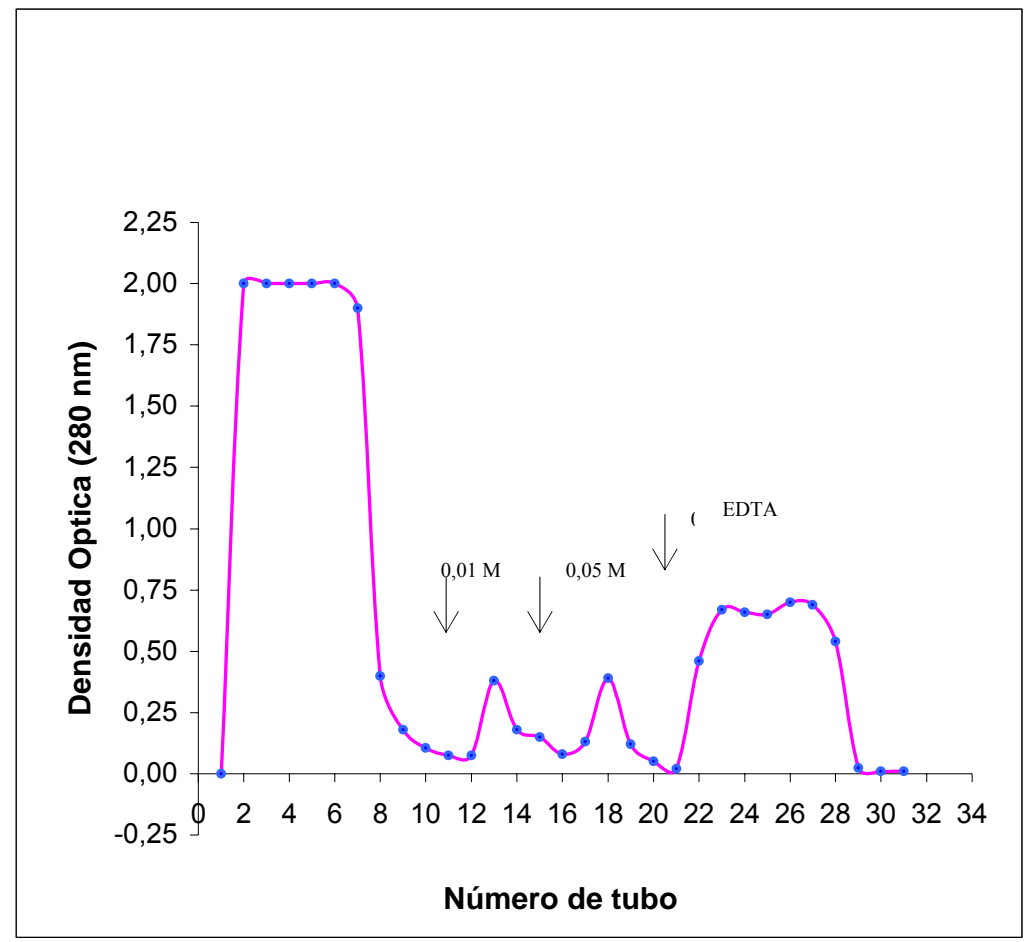

Fig.IV-14: Purificación de apoA-I WT por IMAC. Las proteínas se eluyeron con concentraciones crecientes de imidazol, a fin de eliminar contaminantes de baja afinidad. Se colectaron fracciones cada $2 \mathrm{ml}$, registrando DO a $280 \mathrm{~nm}$.

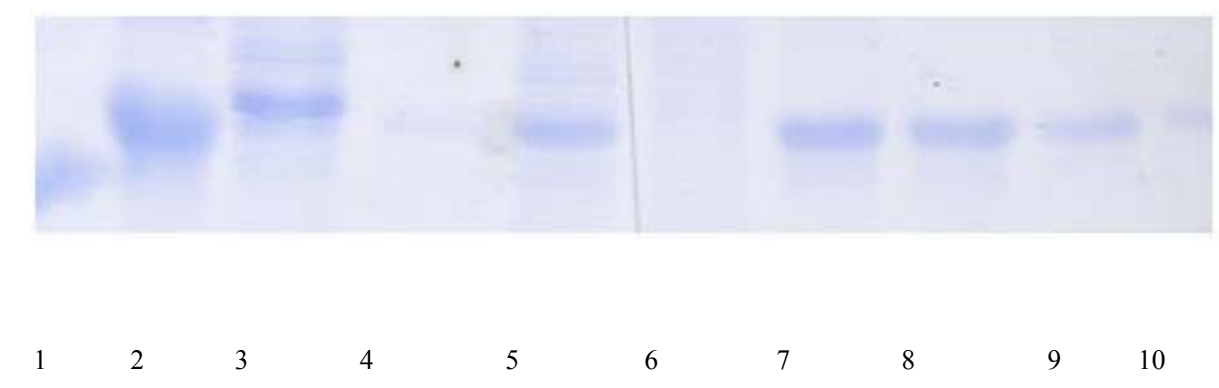

Fig. IV-15: Seguimiento de la purificación de pro-apoA-I WT por SDS-PAGE: 1) ApoA-I de suero; 2) Proteína de fusión de una mutante de apoA-I con cola de polihistidina usada como estandard; 3) Precipitado (solubilizado en el buffer con SDS) luego de la centrifugación al tratar con guanidina $3 \mathrm{M}$; 4) Precipitado (solubilizado en el buffer con SDS) luego de la diálisis; 5) sobrenadante de la centrifugación, luego de la diálisis; 6-9) Fracciones 4, 18, 22, 23 у 27 respectivamente, eluídas de la columna de $\mathrm{ZnCl}_{2}$

Se reunieron las fracciones eluidas con $0,5 \mathrm{M}$ imidazol (fracciones 22 y 23, calles 8 y 9) para la preparación final considerada pura.

Lamentablemente, por razones desconocidas al momento, todos los clones de la proteína mutante W@97 perdieron la capacidad de expresión, por lo que se decidió 
continuar trabajando con los mutantes W@0, W@93, W@104 y W@108, que siempre dieron una expresión adecuada de proteína.

\section{Corte con enzima proteolítica}

La reacción de clivaje con Igasa es muy específica, pero como se mencionó, muy dependiente de las condiciones usadas, siendo las de mejor resultado la incubación durante 24 horas a $32{ }^{\circ} \mathrm{C}$ en buffer tris $20 \mathrm{mM}$, EDTA $5 \mathrm{mM}$, pH 7,8 usando en todas las muestras la misma cantidad de proteína (en relación $0.525 \mu \mathrm{g}$ de igasa/mg de proteína a digerir); y terminando la reacción con PMSF. De esta manera se logró obtener las proteínas mutantes de alto grado de pureza (figura IV-16) para ser usadas en cantidades suficientes para los distintos ensayos de caracterización y demás mediciones.

La mayor dificultad con la Igasa (al menos en nuestro país) es que además de áltamente costosa es muy inestable durante el transporte desde su lugar de origen y durante su almacenamiento. Por esta razón, paralelamente a la obtención de los mutantes de Trp único clivables por Igasa, se trabajó en la introducción en el cDNA de pro-apoA-I salvaje de una región codificante para un sitio de clivaje no enzimático (sensible al medio ácido) en la región donde finaliza el pro-segmento. Aunque esta modificación no fué utilizada para la obtención de las mutantes que se utilizaron en este trabajo, demostró ser muy efectiva y permitirá en el futuro el independizarnos de la Igasa.

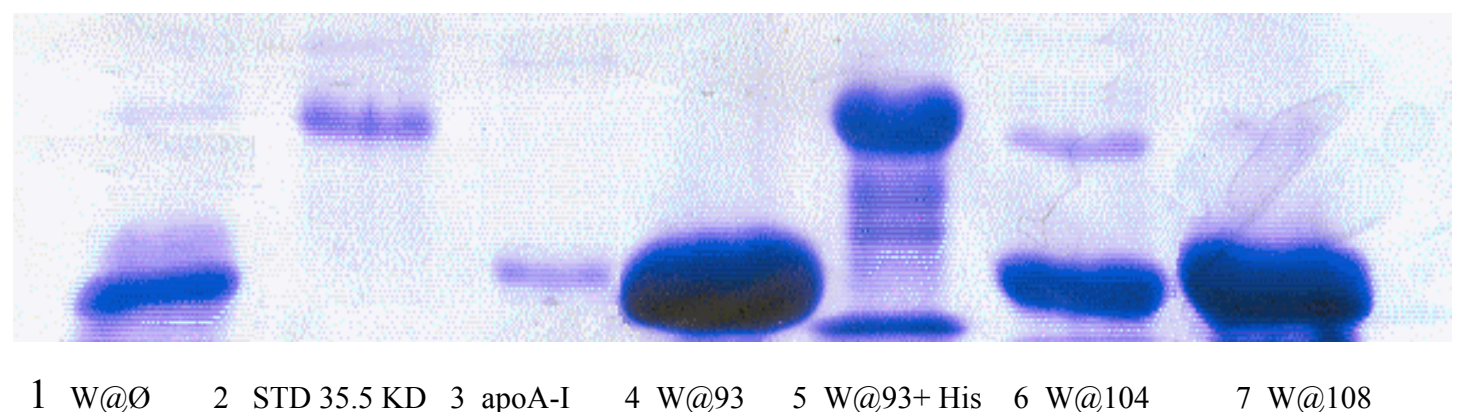

Fig. IV-16: SDS-PAGE $12 \%$ en donde se muestran el resultado de la proteólisis con Igasa de los mutantes W@Ø,W@93,W@104,W@108 
Luego de la proteólisis con Igasa, las muestras son nuevamente pasadas a través de las columnas de IMAC. Esta retiene al péptido con el segmento poli-His liberado así como a la proteína de fusión que no haya sido clivada, (como se observa en la calle 1, 6 y 7). En el no retenido, se recupera a la proteína libre del segmento poli-His.

Como conclusión de esta etapa del trabajo, de las mutantes que se plantearon originalmente se lograron obtener en cantidades adecuadas para los estudios subsiguientes a W@93,W@104 y W@108, además de W@0 que se usó como blanco de fluorescencia inespecífica.

En una primera etapa, estas mutantes fueron caracterizadas, a fin de comprobar la ausencia de alteraciones estructurales y/o funcionales significativas por la sustitución aminoacídica. Así se estudió su estructura secundaria y funcionalmente determinando su capacidad para reaccionar espontáneamente con vesículas de DMPC a la temperatura de transición y formar HDL discoidales. 


\section{Caracterización de las mutantes obtenidas}

\section{1.a) Dicroísmo circular}

La estructura secundaria de los mutantes W@93, W@104 y W@108 fue analizada mediante DC en el UV lejano, en comparación con el W@Ø (Fig IV-17).

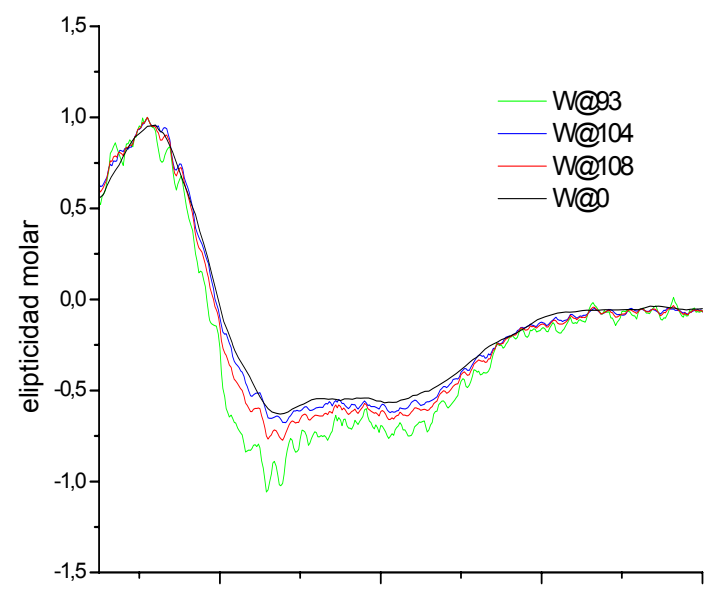

Fig. IV-17: Espectro de dicroísmo circular en el UV lejano medidos a $28{ }^{\circ} \mathrm{C}$, a una concentración de 0.1 $\mathrm{mg} / \mathrm{ml}$

Se puede observar que las mutaciones introducidas a W@Ø no afectan significativamente la estructura secundaria de la proteína, y representan además el espectro típico obtenido para la apoA-I de suero (Leroy et al., 1993) (Li et al., 2004)

\section{1.b) Capacidad de las proteínas mutantes con único Trp para microsolubilizar vesículas de DMPC y generar complejos lipoproteicos}

La capacidad de las proteínas mutantes para microsolubilizar vesículas de DMPC a $24{ }^{\circ} \mathrm{C}$ se comparó con la de la proteína salvaje siguiendo la cinética de reacción por la disminución de la DO a 350nm (dado que la formación de partículas más pequeñas a expensas de la DMPC solubilizada desde los liposomas multilamelares, redunda en una disminución de la turbidez total de la muestra). El ensayo se realizó con una relación molar fosfolípido/proteína de 40:1 (con una concentración de proteína de $0.2 \mathrm{mg} / \mathrm{ml}$ ), normalizando los ensayos a una misma DO inicial. 


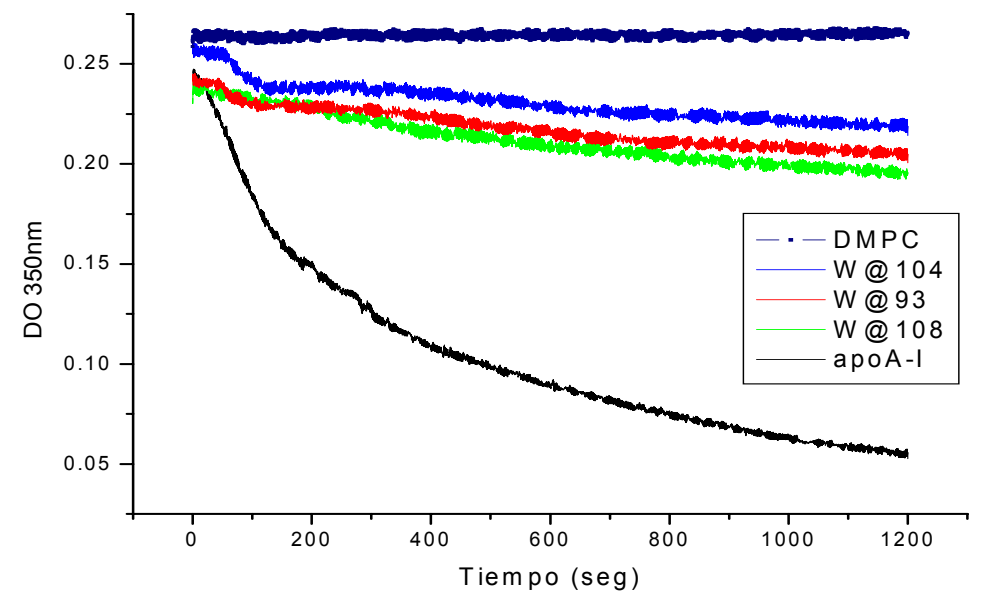

Fig. IV-18:

Micelización de vesículas

multilamelares de DMPC a $24^{\circ} \mathrm{C}$ inducida por los mutantes de apoA-I utilizados.

En la figura IV-18 se puede observar que las tres mutantes de Trp único micelizan a las vesículas de DMPC más lentamente que la apoA-I salvaje. Ya que W@108 tiene la misma secuencia de apoA-I salvaje en la región central, la menor velocidad de micelización observada para las mutantes no puede ser atribuída a los cambios en esta región, sino a alguno de los que son comunes en todas las mutantes (Trp8 $\rightarrow$ Phe, Trp50 $\rightarrow$ Phe o Trp72 $\rightarrow$ Phe).

Aunque la velocidad de micelización es menor para las mutantes que para apoAI salvaje, la extensión de la reacción es similar en todos los casos, ya que, al cabo de 8 hs todas las proteínas alcanzan una DO de 0.1 (no mostrado). Este producto final fue analizado mediante PAGE en condiciones nativas, observandosé la formación de productos lipoproteicos. Cómo fue descripto en la literatura ( $\mathrm{Li}$ et al., 2004), estos complejos corresponden a estructuras discoidales cuyo tamaño es dependiente de la relación fosfolípido/apoA-I inicial. Con la relación utilizada en este caso se obtuvieron discos de $240 \mathrm{kD}$ (aproximadamente $98 \AA$ de diámetro) (ver figura IV-19)

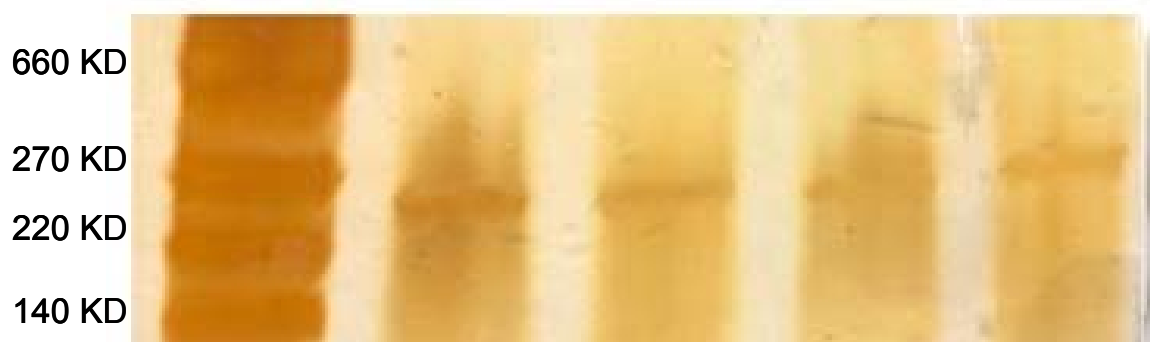

Fig. IV-19: PAGE nativo en gradiente $4-20 \%$ en donde se muestra el resultado de la micelización al cabo de 8 horas. 


\section{Estudios por espectroscopía de fluorescencia}

Las propiedades de la fluorescencia del Trp en estas mutantes son a continuación utilizadas para obtener información sobre la conformación de las repeticiones tipo Y del centro de la molécula de apoA-I en los estados libre, unido a la membrana de vesículas fosfolipídicas o en complejos HDL discoidales. Se analiza: a) el grado de exposición al medio acuoso de los Trp, b) distancias intermoleculares entre los Trp por homotransferencia de energía y c) la extinción o apagado (quenching) de su fluorescencia por grupos paramagnéticos de diferente localización en la bicapa lipídica.

\section{2.a) Estudios de fluorescencia en el estado libre de lípidos. Evidencias de que las} hélices $\mathrm{Y}$ centrales participan en la oligomerización de apoA-I

En el estado libre de lípidos, se realizaron las medidas de fluorescencia en condiciones nativas y desnaturalizantes con Guanidina-HCl 3M, condición en la que se sabe que la proteína se encuentra completamente desplegada (Leroy et al., 1993)
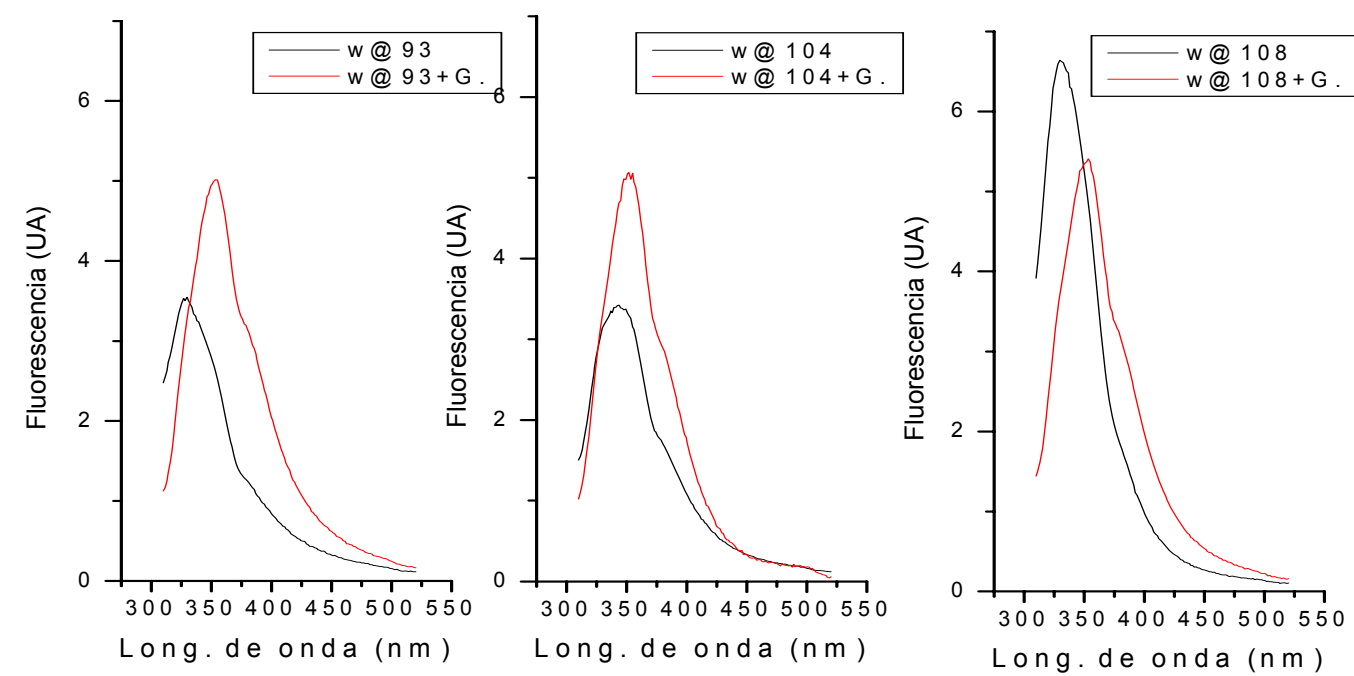

Fig.IV-20: Espectros de fluorescencia en condicones nativas y desnaturalizantes

Para ello se obtuvo el espectro de los distintos mutantes en un espectrofluorómetro SLM4800 con cubetas de paso óptico de $0.2 \mathrm{~cm}$ para excitación, y $1 \mathrm{~cm}$ para la emisión. Se usó una concentración de proteína de $0.1 \mathrm{mg} / \mathrm{ml}$ en buffer fosfato $25 \mathrm{mM}, \mathrm{pH}=7.4$, excitando a $295 \mathrm{~nm}$ y registrando el espectro de emisión entre 300 y $550 \mathrm{~nm}$ con slits de emisión y exitación de 8 . Temperatura de $25{ }^{\circ} \mathrm{C}$. 


\begin{tabular}{|c|c|c|c|c|}
\hline \multirow{2}{*}{} & \multicolumn{2}{|c|}{$\begin{array}{c}\text { Intensidad UA (Unidades } \\
\text { Arbitrarias) }\end{array}$} & \multicolumn{2}{c|}{ max. (nm) } \\
\cline { 2 - 5 } & $\begin{array}{c}\text { Sin } \\
\text { guanidina }\end{array}$ & $\begin{array}{c}\text { Con } \\
\text { guanidina }\end{array}$ & $\begin{array}{c}\text { Sin } \\
\text { guanidina }\end{array}$ & $\begin{array}{c}\text { Con } \\
\text { guanidina }\end{array}$ \\
\hline W@93 & 3.53 & 5.00 & 330 & 350 \\
\hline W@104 & 3.40 & 5.02 & 342 & 351 \\
\hline W@108 & 6.61 & 5.05 & 331 & 351
\end{tabular}

Tabla IV-1: se muestran en la tabla las intensidades de fluorescencia en unidades arbitrarias $\mathrm{y}$ los max. de emisión de las mutantes de W@93, W@104 y W@108.

En la tabla IV-1 se resumen los datos espectrales mostrados en la figura IV-20: Se puede observar que, en los mutantes W@93 y W@108, el Trp se encuentra en un ambiente ó entorno relativamente no polar, como lo indica la longitud de onda del máximo de emisión; mientras que el Trp de W@104 estaría en un entorno relativamente más polar. Como es de esperar, todos los mutantes sufren un corrimiento de la fluorescencia del Trp hacia mayores longitudes de onda (corrimiento al rojo) cuando se desnaturalizan con guanidina-HCl 3M. Esto indica que cierto grado de "protección" de la exposición de los Trp al medio acuoso que existe en la proteína nativa, desaparece en la proteína completamente desnaturalizada.

Generalmente, la exposición al entorno acuoso de Trp produce una apreciable disminución en su rendimiento cuántico además del mencionado corrimiento al rojo de la fluorescencia. Se puede observar que si bien esto ocurre en alguna medida para el caso del mutante W@108 cuando se desnaturaliza con guanidina- $\mathrm{HCl}$ (se observa una disminución en la intensidad de emisión acompañando al corrimiento al rojo), lo contrario ocurre para W@93 y W@104 (el corrimiento de la emisión al rojo va acompañado de un aumento en intensidad)

Este fenómeno se podría explicar por el hecho de que en condiciones nativas la apoA-I se encuentra en equilibrio entre monómero, dímero, y mayores oligómeros (McGuire et al., 1996). Si los residuos de Triptofano se encuentran muy próximos entre sí en los oligómeros, podría ocurrir en ellos el fenómeno de homotransferencia de energía, que resultaría en una disminución del rendimiento cuántico en el estado nativo. Como la desnaturalización con guanidina- $\mathrm{HCl}$ resulta en la disrupción de la estructura oligomérica y la completa monomerización de la proteína, la homotransferencia de energía dejaría de ocurrir y se produciría un aumento en la intensidad de fluorescencia. 
Además de disminuir el rendimiento cuántico, la homotransferencia de energía resulta en una disminución de la anisotropía de la emisión, y ésto puede ser utilizado para su reconocimiento. Para constatar si ocurre este fenómeno debido a la oligomerización en las mutantes no desnaturalizadas, se realizaron mediciones de intensidad y anisotropía en función de la concentración de las proteínas. Ya que el aumento de concentración proteica desplaza el equilibrio hacia la formación de oligómeros, de existir homotransferencia de energía en éstos, la misma debería aumentar con la concentración, lo que debería observarse como un decrecimiento en el rendimiento cuántico y la anisotropía.

Los espectros de emisión (normalizados por la concentración proteica) para diferentes concentraciones de proteína entre 0.0125 y $0.1 \mathrm{mg} / \mathrm{ml}$ se muestran en la figuraIV-21 y los datos de intensidad normalizados por la concentración (proporcionales al rendimiento cuántico) y la longitud de onda del máximo de la emisión son indicados en la tabla IV-2.
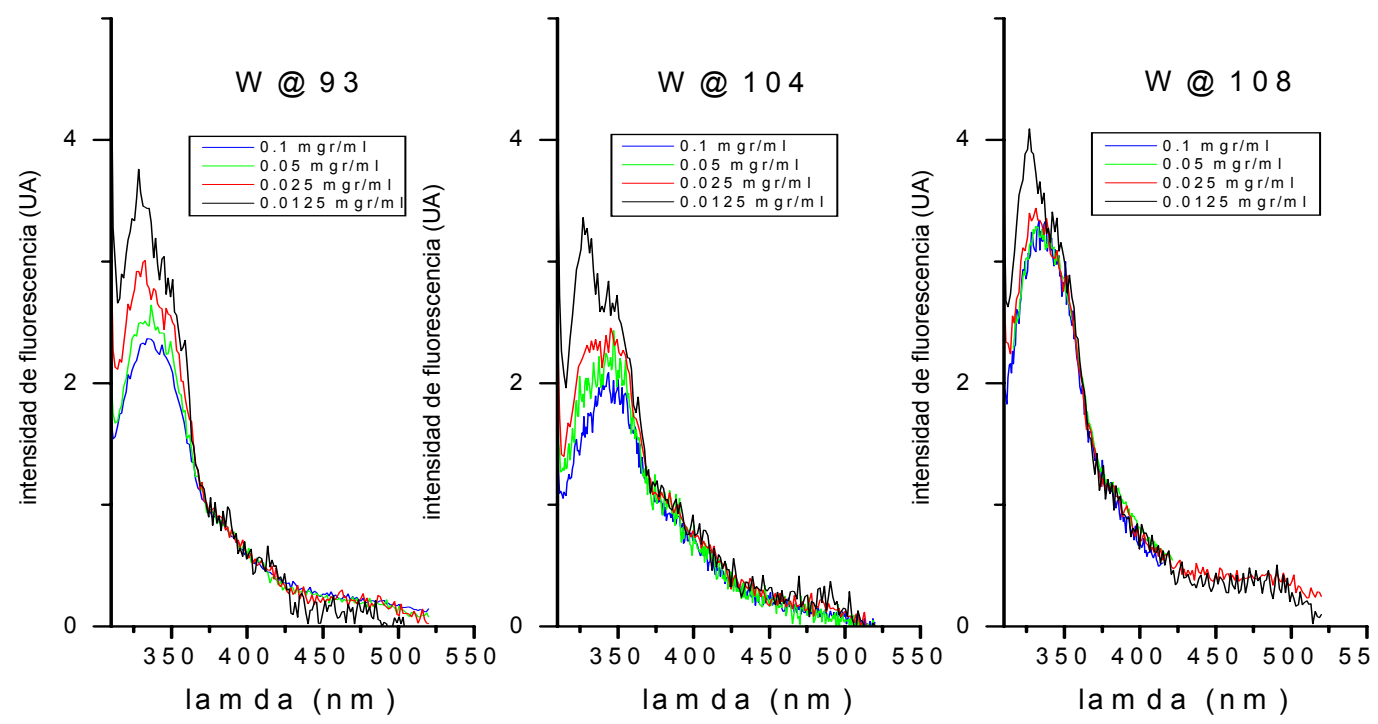

Fig. IV-21: Espectros de fluorescencia a diferentes concentraciones de proteínas corregidos por la concentración 


\begin{tabular}{|c|c|c|c|c|c|c|c|c|}
\hline & \multicolumn{2}{|c|}{$\begin{array}{c}\text { Conc. de prot. } \\
0.1 \mathrm{mg} / \mathrm{ml}\end{array}$} & \multicolumn{2}{c|}{$\begin{array}{c}\text { Conc. de prot. } \\
0.05 \mathrm{mg} / \mathrm{ml}\end{array}$} & \multicolumn{2}{c|}{$\begin{array}{c}\text { Conc. de prot. } \\
0.025 \mathrm{mg} / \mathrm{ml}\end{array}$} & \multicolumn{2}{c|}{$\begin{array}{c}\text { Conc. de prot. } \\
0.0125 \mathrm{mg} / \mathrm{ml}\end{array}$} \\
\cline { 2 - 9 } & $\begin{array}{c}\text { Intensidad } \\
(\mathrm{UA})\end{array}$ & $\begin{array}{c}\lambda \max \\
(\mathrm{nm}) .\end{array}$ & $\begin{array}{c}\text { Intensidad } \\
(\mathrm{UA})\end{array}$ & $\begin{array}{c}\lambda \text { max. } \\
(\mathrm{nm})\end{array}$ & $\begin{array}{c}\text { Intensidad } \\
(\mathrm{UA})\end{array}$ & $\begin{array}{c}\lambda \text { max } \\
(\mathrm{nm}) .\end{array}$ & $\begin{array}{c}\text { Intensidad } \\
(\mathrm{UA})\end{array}$ & $\begin{array}{c}\lambda \text { max } \\
(\mathrm{nm}) .\end{array}$ \\
\hline W@93 & 2.35 & 334 & 2.49 & 335 & 3.11 & 334 & 3.44 & 333 \\
\hline W@104 & 1.99 & 345 & 2.23 & 344 & 2.40 & 343 & 2.70 & 343 \\
\hline W@108 & 3.20 & 333 & 3.27 & 334 & 3.33 & 333 & 3.50 & 334 \\
\hline
\end{tabular}

Tabla IV-2: Datos de intensidad de fluorescencia (Unidades Arbitrarias) normalizados y máximos de emisión en función de la concentración de proteína

No se observan corrimentos en las longitudes de onda de emisión en función de la concentración de proteína para ninguna de las mutantes, indicando que la oligomerización no produce cambios en la polaridad del entorno de los Trp. Tanto en monómeros como en oligómeros, la posición reportada por W@104 se encuentra en un entorno relativamente más polar que las reportadas por W@93 y W@108

La dependencia de la intensidad normalizada y de la anisotropía con la concentración de proteína se muestra en la figura IV-22. Se observa que en las tres mutantes (pero especialmente en W@93 y W@104) ocurre una disminución en el rendimiento cuántico y la anisotropía de emisión de Trp al incrementarse la concentración proteica, indicando la existencia de homotransferencia de energía en los oligomeros. Es de notar que los Ro para la homotransferencia Trp-Trp son del orden de 4-15 Å dependiendo del entorno (Lakowicz, 1999) por lo que la homotransferencia no sería detectable a distancias mayores de 20-25 Å como máximo. Así, estos resultados indican que las hélices Y centrales de apoA-I (donde se encuentran los Trp de estas mutantes) participan en la dimerización (y oligomerización) de esta proteína quedando en estrecho contacto entre sí en los oligómeros. 

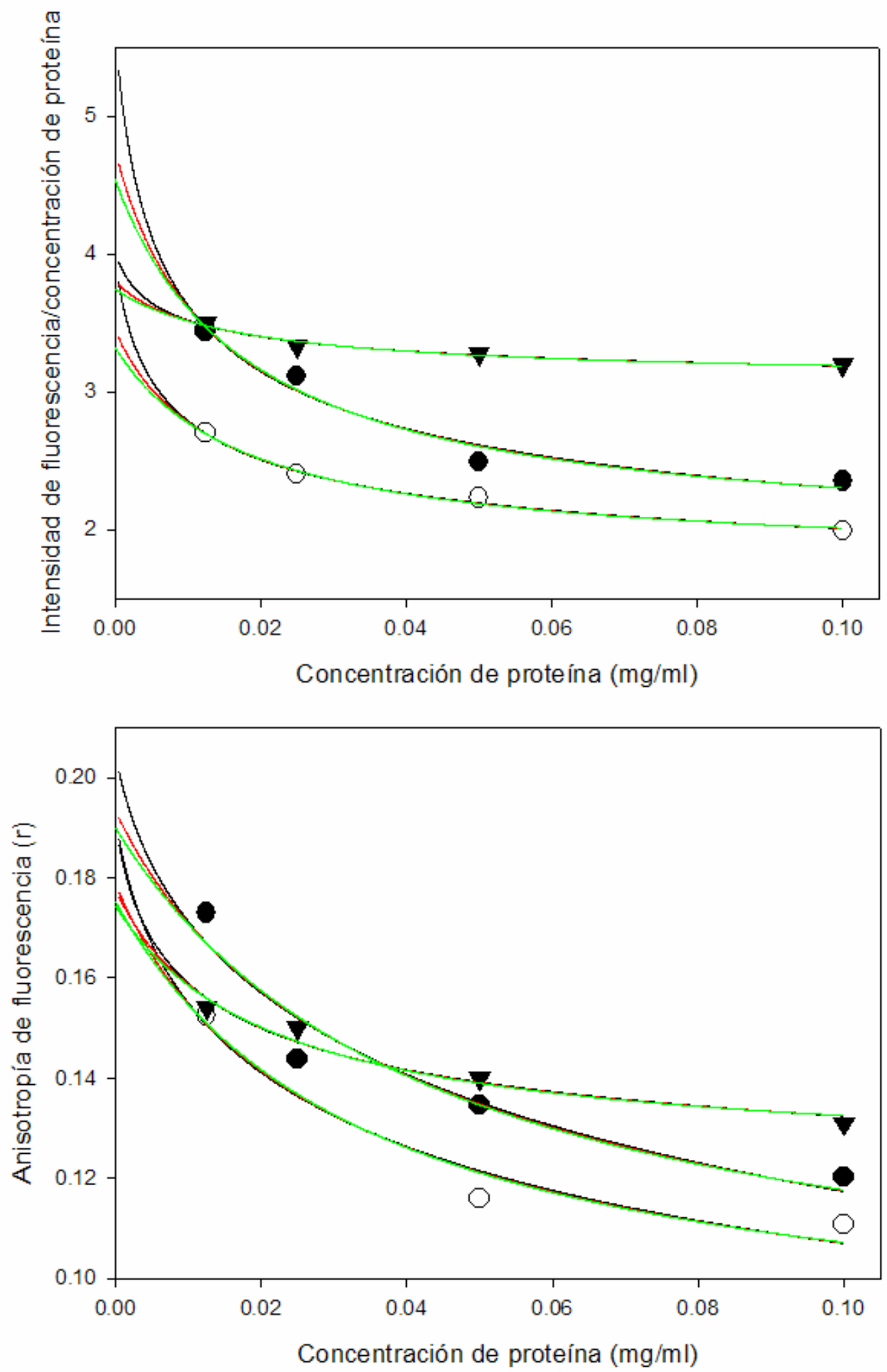

W@93

WW@104

₹W@108

Modelo A fm $=(\operatorname{sqrt}(4 \mathrm{~K}[\mathrm{Pt}]+1)-1) /(2 \mathrm{~K}[\mathrm{Pt}])$

Modelo B fm $=(2 \mathrm{~K}[\mathrm{Pt}]+1$-sqrt $(4 \mathrm{~K}[\mathrm{Pt}]+1)) /\left(2 \mathrm{~K}^{2}[\mathrm{Pt}]^{2}\right)$ Modelo $\mathrm{C} \mathrm{fm}=1 /(1+\mathrm{K}[\mathrm{Pt}])$
Figura IV-22. Influencia de la concentración de proteína sobre la intensidad (arriba) y anisotropía (debajo) de la fluorescencia de w@93,w@104y w@108. 
A continuación se trató de calcular la efíciencia de homotransferencia de energía en los oligómeros ya que de ella sería posible estimar las distancias intermoleculares entre las posiciones ocupadas por los Trp en estas mutantes. Para estimar la eficiencia de homotransferencia es necesario conocer la intensidad (y/o anisotropía) de la emisión de la proteína monomérica y de la proteína oligomérica por separado. Ya que en el rango de concentración medible es imposible tener 100\% de monómeros o 100\% de oligómeros, la intensidad y anisotropía de los mismos se obtuvo por extrapolación a dilución infinita (para el monómero) o concentración infinita (para el oligómero). Se asumió que la intensidad de fluorescencia normalizada por la concentración (Fn) sigue la relación:

$\mathrm{Fn}=\mathrm{F} /[\mathrm{Pt}]=($ Fem $[\mathrm{Pm}]+$ Feo $[\mathrm{Po}]) /[\mathrm{Pt}]=$ Fem fm + Feo fo $=$ Fem fm + Feo $(1-\mathrm{fm})$

donde $[\mathrm{Pt}],[\mathrm{Pm}]$ y $[\mathrm{Po}]$ son respectivamente las concentraciones $(\mathrm{en} \mathrm{mg} / \mathrm{ml}$ ) de proteína total, monomérica y oligomérica. Fem y Feo son respectivamente la fluorescencia específica (por unidad de concentración) de monómeros y oligómeros; siendo fm y fo las fracciones de proteína monomérica y oligomérica respectivamente $(\mathrm{fm}=[\mathrm{Pm}] /[\mathrm{Pt}]$ y $\mathrm{fo}=[\mathrm{Po}] /[\mathrm{Pt}])$, que cumplirán la relación: $\mathrm{fm}+\mathrm{fo}=1$

Por otro lado, la anisotropía de fluorescencia (r) estará dada por:

$\mathrm{r}=(\mathrm{rm} \mathrm{Fem}[\mathrm{Pm}]+$ ro Feo $[\mathrm{Po}]) /(\mathrm{Fem}[\mathrm{Pm}]+\mathrm{Feo}[\mathrm{Po}])$

donde rm y ro son las anisotropía de la emisión del monómero y de oligómeros, respectivamente. Expresando $\mathrm{r}$ en función de las fracciones fm y fo:

$$
\begin{aligned}
\mathrm{r} & =(\mathrm{rm} \mathrm{Fem} \mathrm{fm}+\text { ro Feo fo }) /(\text { Fem fm }+ \text { Feo fo }) \\
\text { ó } & \mathrm{r}=(\mathrm{rm} \mathrm{Fem} \mathrm{fm}+\text { ro Feo }(1-\mathrm{fm})) /(\text { Fem fm }+ \text { Feo }(1-\mathrm{fm}))
\end{aligned}
$$

Se asume así que tanto el rendimiento cuántico como la anisotropía son independientes del número de agregación. Esto es, ellas serán iguales en dímeros, trímeros u oligómeros de mayor tamaño.

Se asumieron tres modelos diferentes para la dependencia de la fracción de proteína monomérica ( $\mathrm{fm})$ con la concentración de proteína total $[\mathrm{Pt}]$ : 
A) El primero fue considerar un equilibrio simple entre monómeros y dímeros. Si bien es sabido que apoA-I puede formar agregados mayores, sólo se detectan dímeros a una concentración de 0,1 mg/ml (McGuire et al., 1996). En este caso, la relación entre fm y $[\mathrm{Pt}]$ será:

$$
\mathrm{fm}=(\operatorname{sqrt}(4 \mathrm{~K}[\mathrm{Pt}]+1)-1) /(2 \mathrm{~K}[\mathrm{Pt}])
$$

B) El segundo modelo desarrollado fue

$$
\mathrm{fm}=(2 \mathrm{~K}[\mathrm{Pt}]+1-\operatorname{sqrt}(4 \mathrm{~K}[\mathrm{Pt}]+1)) /\left(2 \mathrm{~K}^{2}[\mathrm{Pt}]^{2}\right)
$$

C) En el tercer modelo se asumió un número de agregación infinito y que la constante de asociación de un monómero a un oligómero no cambia con el número de agregación previo. Esto resulta en la siguiente relación relativamente sencilla cuya derivación se explica en el Apéndice I

$$
\mathrm{fm}=1 /(1+\mathrm{K}[\mathrm{Pt}])
$$

Las tres ecuaciones indicadas fueron ajustadas por medio de regresión no lineal a los datos experimentales (curvas de intensidad normalizada y de anisotropía vs. concentración de proteína) de manera de estimar los parámetros Fem, Feo, rm y ro para cada uno de los mutantes. Las constantes de equilibrio $(\mathrm{K})$ no variaron mayormente entre las diferentes mutantes, indicando que las mutaciones no modifican la tendencia de la proteína a oligomerizar. Por tanto, se realizó un ajuste conjunto a los datos de las tres mutantes asumiendo la misma constante de equilibrio para todas. Los parámetros obtenidos son indicados en la tabla 3 y las curvas de regresión para los tres modelos asumidos se muestran en la figura IV-22. Los tres modelos sólo difieren apreciablemente entre sí a muy bajas concentraciones de proteína, por lo que no es posible distinguir cuál se ajusta mejor a los datos experimentales. El tercer modelo, sin embargo, resultó en un menor error para los parámetros calculados.

Se hicieron dos estimaciones de la eficiencia de homotransferencia de energía Trp-Trp en los oligómeros. La primera (Ef) a partir de los valores de fluorescencia específica de monómeros y oligómeros (Fem y Feo), y la segunda (Er) usando los correspondientes valores de anisotropía (rm y ro). Con estos valores de eficiencia se realizaron dos estimaciones de las distancias Trp-Trp en los oligómeros ( df y dr). Como puede observarse en la tabla 3, las distancias así estimadas son relativamente independientes dentro del margen de error tanto del modelo de oligomerización asumido, como de si estas distancias son estimadas a partir de los datos de intensidad o de anisotropía de fluorescencia. Para W@93 y W@104 y, los correspondientes Trp se 
encuentran a una distancia estimada entre los 3,5 y $5 \AA$ en los oligómeros, mientras que esta distancia es un poco mayor para el caso de W@108.

Estos resultados indican que el par de hélices Y centrales de apoA-I participa interactuando entre sí en el proceso de oligomerización, quedando en estrecho contacto en los oligómeros

Tabla IV-3 Intensidad y anisotropía de fluorescencia de las mutantes W@93, W@104 y W@108 en los estados monomérico y oligomérico. Eficiencia de homotransferencia de energía y distancias estimadas entre los Trp en los oligómeros.

\begin{tabular}{|c|c|c|c|c|c|c|c|c|c|}
\hline Mut. & Modelo & Fem & Feo & rm & ro & Ef & Er & df $(\AA)$ & dr $(\AA)$ \\
\hline & A & $5,65 \pm 2,79$ & $1,39 \pm 0,42$ & $0,204 \pm 0,013$ & $0,021 \pm 0,025$ & $0,75 \pm 0,20$ & $0,90 \pm 0,13$ & $4,1 \pm 0,7$ & $3,5 \pm 0,8$ \\
W@93 & B & $4,76 \pm 0,85$ & $1,81 \pm 0,25$ & $0,193 \pm 0,011$ & $0,078 \pm 0,014$ & $0,62 \pm 0,12$ & $0,60 \pm 0,09$ & $4,6 \pm 0,4$ & $4,7 \pm 0,3$ \\
& C & $4,54 \pm 0,58$ & $1,89 \pm 0,20$ & $0,190 \pm 0,010$ & $0,086 \pm 0,012$ & $0,58 \pm 0,10$ & $0,55 \pm 0,09$ & $4,7 \pm 0,3$ & $4,8 \pm 0,3$ \\
& & & & & & & & & \\
\hline & A & $3,98 \pm 1,66$ & $1,47 \pm 0,27$ & $0,192 \pm 0,015$ & $0,045 \pm 0,018$ & $0,63 \pm 0,22$ & $0,77 \pm 0,11$ & $4,6 \pm 0,7$ & $4,1 \pm 0,4$ \\
W@104 & B & $3,45 \pm 0,52$ & $1,72 \pm 0,17$ & $0,179 \pm 0,012$ & $0,078 \pm 0,011$ & $0,50 \pm 0,12$ & $0,56 \pm 0,09$ & $5,0 \pm 0,4$ & $4,8 \pm 0,3$ \\
& C & $3,32 \pm 0,36$ & $1,77 \pm 0,14$ & $0,175 \pm 0,011$ & $0,084 \pm 0,009$ & $0,47 \pm 0,10$ & $0,52 \pm 0,08$ & $5,1 \pm 0,3$ & $4,9 \pm 0,3$ \\
& & & & & & & & & \\
\hline & A & $4,02 \pm 0,74$ & $2,96 \pm 0,17$ & $0,191 \pm 0,007$ & $0,111 \pm 0,005$ & $0,26 \pm 0,18$ & $0,42 \pm 0,05$ & $5,9 \pm 0,9$ & $5,3 \pm 0,2$ \\
& B & $3,80 \pm 0,27$ & $3,07 \pm 0,12$ & $0,178 \pm 0,005$ & $0,121 \pm 0,004$ & $0,19 \pm 0,09$ & $0,32 \pm 0,04$ & $6,3 \pm 0,6$ & $5,7 \pm 0,2$ \\
& C & $3,75 \pm 0,21$ & $3,09 \pm 0,10$ & $0,174 \pm 0,005$ & $0,123 \pm 0,003$ & $0,18 \pm 0,07$ & $0,29 \pm 0,04$ & $6,5 \pm 0,5$ & $5,8 \pm 0,2$ \\
& & & & & & & & & \\
\hline
\end{tabular}

Los valores de intensidad de fluorescencia específica y anisotropía de monómeros (Fem y rm) y oligómeros (Feo y ro), así como los correpondientes errores estándares indicados fueron obtenidos por regresión no lineal ajustando las ecuaciones correspondientes a los modelos A, B y C a los datos experimentales de la figura IV-22. La eficiencia para la homotransferencia de energía y la distancia entre los Trp en los oligómeros fueron calculadas a partir de los valores de intensidad (Ef y df, respectivamente) o a partir de los valores de anisotropía (Er y dr respectivamente). Los errores indicados para las estimaciones de eficiencia y distancias se obtuvieron por progresión de los errores de intensidad y anisotropía. Para la estimación de las distancias se usó un valor de R0 de $5 \AA$ 


\section{Apéndice I: Derivación de la dependencia de la concentración de proteína monomérica en función de la concentración de proteína total}

Si la oligomerización de una proteína ocurre por la adición de un monómero a un oligómero preformado, se pueden plantear los siguientes equilibrios. Si la constante de equilibrio $(\mathrm{K})$ es la misma independientemente del número de agregación, tendremos además las siguientes relaciones:
$\mathrm{P}+\mathrm{P} \Leftrightarrow \mathrm{P}_{2}$
$\mathrm{K}=\left[\mathrm{P}_{2}\right] /[\mathrm{P}]^{2}$
$\left[\mathrm{P}_{2}\right]=\mathrm{K}[\mathrm{P}]^{2}$
$\mathrm{P}+\mathrm{P}_{2} \Leftrightarrow \mathrm{P}_{3}$
$\mathrm{K}=\left[\mathrm{P}_{3}\right] /\left(\left[\mathrm{P}_{2}\right][\mathrm{P}]\right)$
$\left[\mathrm{P}_{3}\right]=\mathrm{K}\left[\mathrm{P}_{2}\right][\mathrm{P}]=\mathrm{K}^{2}[\mathrm{P}]^{3}$
$\mathrm{P}+\mathrm{P}_{3} \Leftrightarrow \mathrm{P}_{4}$
$\mathrm{K}=\left[\mathrm{P}_{4}\right] /\left(\left[\mathrm{P}_{3}\right][\mathrm{P}]\right)$
$\left[\mathrm{P}_{4}\right]=\mathrm{K}\left[\mathrm{P}_{3}\right][\mathrm{P}]=\mathrm{K}^{3}[\mathrm{P}]^{4}$

$\mathrm{P}+\mathrm{P}_{\mathrm{n}-1} \Leftrightarrow \mathrm{P}_{\mathrm{n}}$

$\mathrm{K}=\left[\mathrm{P}_{\mathrm{n}}\right] /\left(\left[\mathrm{P}_{\mathrm{n}-1}\right][\mathrm{P}]\right)$

$\left[\mathrm{P}_{\mathrm{n}}\right]=\mathrm{K}\left[\mathrm{P}_{\mathrm{n}-1}\right][\mathrm{P}]=\mathrm{K}^{\mathrm{n}-1}[\mathrm{P}]^{\mathrm{n}}$

Además, la concentración total de proteína en $\mathrm{mg} / \mathrm{ml}$ ([Pt]) será la suma de concentraciones de las diferentes especies de oligómeros:

$$
\begin{aligned}
& {[\mathrm{Pt}]=[\mathrm{P}]+\left[\mathrm{P}_{2}\right]+\left[\mathrm{P}_{3}\right]+\left[\mathrm{P}_{4}\right]+\ldots .+\left[\mathrm{P}_{\mathrm{n}-1}\right]+\left[\mathrm{P}_{\mathrm{n}}\right]} \\
& {[\mathrm{Pt}]=[\mathrm{P}]+\mathrm{K}[\mathrm{P}]^{2}+\mathrm{K}^{2}[\mathrm{P}]^{3}+\mathrm{K}^{3}[\mathrm{P}]^{4}+\ldots .+\mathrm{K}^{\mathrm{n}-2}[\mathrm{P}]^{\mathrm{n}-1}+\mathrm{K}^{\mathrm{n}-1}[\mathrm{P}]^{\mathrm{n}}}
\end{aligned}
$$

Si multiplicamos ambos miembros de la ecuación (b) por K:

$\mathrm{K}[\mathrm{Pt}]=\mathrm{K}[\mathrm{P}]+\mathrm{K}^{2}[\mathrm{P}]^{2}+\mathrm{K}^{3}[\mathrm{P}]^{3}+\mathrm{K}^{4}[\mathrm{P}]^{4}+\ldots .+\mathrm{K}^{\mathrm{n}-1}[\mathrm{P}]^{\mathrm{n}-1}+\mathrm{K}^{\mathrm{n}}[\mathrm{P}]^{\mathrm{n}}$

$\mathrm{Y}$ dividiendo ambos miembros de la ecuación (b) por $[\mathrm{P}]$ :

$[\mathrm{Pt}] /[\mathrm{P}]=1+\mathrm{K}[\mathrm{P}]+\mathrm{K}^{2}[\mathrm{P}]^{2}+\mathrm{K}^{3}[\mathrm{P}]^{3}+\mathrm{K}^{4}[\mathrm{P}]^{4}+\ldots .+\mathrm{K}^{\mathrm{n}-1}[\mathrm{P}]^{\mathrm{n}-1}$

Restando la ecuación (c) de la ecuación (d):

$[\mathrm{Pt}] /[\mathrm{P}]-\mathrm{K}[\mathrm{Pt}]=1-\mathrm{K}^{\mathrm{n}}[\mathrm{P}]^{\mathrm{n}}$

Para $\mathrm{n}$ que tiende a infinito, y si $\mathrm{K}[\mathrm{P}]<1$, tendremos una serie convergente y $\mathrm{K}^{\infty}[\mathrm{P}]^{\infty}$ será igual a 0 . Así, la ecuación (e) se reduce simplemente a:

$[\mathrm{Pt}] /[\mathrm{P}]-\mathrm{K}[\mathrm{Pt}]=1$

Reordenando para despejar $[\mathrm{P}]$, tendremos que:

$[\mathrm{P}]=[\mathrm{Pt}] /(1+\mathrm{K}[\mathrm{Pt}])$

Dividiendo $(\mathrm{g})$ por $[\mathrm{Pt}]$, tendremos que la fracción de proteína en la forma monomérica (fm) dependerá de la concentración de proteína total [Pt] según la siguiente ecuación:

$[\mathrm{P}] /[\mathrm{Pt}]=\mathrm{fm}=1 /(1+\mathrm{K}[\mathrm{Pt}])$

Y la fracción de proteína oligomérica (fo) será:

$\mathrm{fo}=1-\mathrm{fm}=1-1 /(1+\mathrm{K}[\mathrm{Pt}])=\mathrm{K}[\mathrm{Pt}] /(1+\mathrm{K}[\mathrm{Pt}])$ 


\section{2.b) Conformación de la región central de apoA-I en el estado unido a membranas}

Con el fin de detectar las posibles modificaciones en el entorno de los Trp de estas mutantes cuando se unen a membrana, se estudió el espectro de fluorescencia de las distintas variantes en presencia de vesículas unilamelares de POPC más 20\% de colesterol (ver materiales y métodos). Se trabajó con una concentración de lípidos de $2.5 \mathrm{mM}$ y concentración de proteína de $0.04 \mathrm{mg} / \mathrm{ml}$. Como se mencionó, en estas condiciones apoA-I se une a las vesículas sin producir su micelización o formación de complejos discoidales. Los datos obtenidos se resumen en la siguiente tabla:

\begin{tabular}{|c|c|c|c|c|}
\hline \multirow{2}{*}{} & \multicolumn{2}{|c|}{ Intensidad (UA) } & \multicolumn{2}{c|}{$\lambda \max (\mathrm{nm})$} \\
\cline { 2 - 5 } & $\begin{array}{c}\text { Libre de } \\
\text { lípidos }\end{array}$ & $\begin{array}{c}\text { Con } \\
\text { vesículas }\end{array}$ & $\begin{array}{c}\text { Libre de } \\
\text { lípidos }\end{array}$ & $\begin{array}{c}\text { Con } \\
\text { vesículas }\end{array}$ \\
\hline W@93 & 2.33 & 1.25 & 332 & 339 \\
\hline W@104 & 0.62 & 0.79 & 343 & 341 \\
\hline W@108 & 3.11 & 3.30 & 332 & 334 \\
\hline
\end{tabular}

Tabla IV-4: datos de intensidad de fluorescencia de las mutantes de apoA-I en presencia y ausencia de lípidos. La mutante 104 posee una menor intensidad porque se debió disminuir la ganacia del equipo.

Se puede observar de la longitud de onda de los máximos de emisión, que el entorno de los Trp de los mutantes W@104 y W@108 prácticamente no se ve modificado por el agregado de vesículas. En ambas condiciones (con o sin vesículas), el residuo 104 se encuentra en un entorno relativamente más polar que el residuo 108.

El agregado de vesículas, sin embargo, resultó en un notable corrimiento hacia el rojo de la emisión del Trp de W@93, lo que puede ser asociado con un cambio a un entorno más polar en el estado unido a membrana. Evidentemente, este residuo no interactúa directamente con la región hidrofófica de la membrana, aunque sí podría hacerlo con los grupos polares de los fosfolípidos.

Con la mutante W@93 también se observa una notable disminución en la intensidad de emisión de su Trp por el agregado de las vesículas. En gran parte, esto es esperable del entorno más polar indicado por el corrimiento al rojo, aunque no es posible descartar que también ocurra un incremento en homotransferencia de energía en el estado unido a membrana. Lamentablemente, mediciones de anisotropía como las 
usadas para detectar homotransferencia en los oligómeros en solución acuosa, son muy complicadas y afectadas por un gran margen de error en presencia de vesículas debido a la turbidez de las mismas. Por tal razón no nos fue posible determinar si existe o no homotransferencia Trp-Trp en el estado unido a membrana de W@93.

En el caso de W@104 y W@108, se detecta en cambio un leve aumento en la intensidad de fluorescencia respecto al estado libre. Esto podría atribuirse a un mayor rendimiento cuántico por la interacción con lípidos, ó en el caso del W@104, a un alejamiento relativo intermolecular respecto al que presentaba en el estado libre. Así, se puede concluir que la formación de dímeros u oligómeros de estas mutantes en el estado unido a membrana no resulta en homotransferencia de energía como ocurre para la oligomerización en solución.

Así, estos datos indican que al menos la hélice 3 sufre una reorganización, aunque no es posible determinar si en este caso ocurre algún cambio en la distancia entre los residuos 93 entre los dímeros en solución acuosa y los dímeros de membrana. Esta reorganización podría involucrar a la hélice 4, pudiendo por lo tanto esta región estar involucrada en la formación del estado oligomérico detectado mediante crosslinking en la unión de la apo a membranas.

\section{2.c) Topología de inserción en la membrana de las hélices Y centrales. Mediciones de extinción de la fluorescencia de Trp por extinguidores (quenchers) paramagnéticos localizados a diferente profundidad en la bicapa lipídica}

Con el objeto de distinguir entre los dos modos de inserción en la membrana del par de hélices 3-4 que se plantearon (ver sección Objetivos), se procuró información sobre la profundidad en la que se localizan en la bicapa lipídica los residuos Trp de las mutantes W@93, W@104 y W@108. Para ello se determinó la eficiencia de extinción (quenching) de la fluorescencia del Trp de cada mutante por vesículas fosfolipídicas conteniendo una serie de análogos de fosfatidilcolina con un grupo paramagnético en el grupo polar (Tempo-PC), o en diferentes posiciones de la cadena hidrocarbonada (ndoxil-PC, donde $n=5,10$ o 14). Aunque en membranas en el estado fluído tanto el grupo polar como las cadenas hidrocarbonadas de los fosfolípidos son bastante flexibles, la localización promedio de los grupos paramagnéticos extinguidores será bien superficial (en la región de los grupos polares para Tempo-PC), y con mayor profundidad en la región hidrocarbonada a medida que aumente "n" en los n-doxil-PC. Como la extinción 
de la fluorescencia por estos grupos paramagnéticos depende de su aproximación al estado excitado del fluoróforo (en este caso los Trp), la probabilidad de extinción será máxima si la profundidad en la que se localiza el residuo Trp en la membrana coincide con la del grupo paramagnético. Otra sonda paramagnética utilizada en estos experimentos fué el análogo de colesterol 3- $\beta$-Doxil-colestano, el que nos podría informar sobre la existencia de alguna interacción preferencial de las hélices centrales de apoA-I con colesterol.

Se prepararon vesículas unilamelares conteniendo POPC/colesterol (4/1 en mol), o conteniendo POPC/colesterol/SL (3/1/1 en mol, donde SL es Tempo-PC, 5-, 10- o 14doxil-PC, o a una relación 4/SL-C cuando SL es 3- $\beta$-Doxil-colestano. Los espectros de emisión de las mutantesW@93,W@104 y W@108 (a una concentración de 0,1mg/ml) fueron registrados entre 310 y $550 \mathrm{~nm}$ en ausencia y presencia de diferentes concentraciones de cada tipo de vesículas unilamelares. La longitud de onda de excitación fue de $295 \mathrm{~nm}$, con una resolución de $8 \mathrm{~nm}$ en excitación y emisión. Todas las medidas se realizaron en un espectrofluorómetro SLM4800 con cubetas de 0,2 cm de paso óptico en exitación y $1 \mathrm{~cm}$ en emisión. El medio consistió de buffer fosfato sódico $25 \mathrm{mM} \mathrm{pH} \mathrm{7,4} \mathrm{y} \mathrm{la} \mathrm{temperatura} \mathrm{fue} \mathrm{controlada} \mathrm{en} 25^{\circ} \mathrm{C}$.

Luego de corregir los espectros por la señal de scattering debida a las vesículas, así como por el filtro interno producido por las mismas, la intensidad fue estimada por la integración de los espectros entre 315 y $380 \mathrm{~nm}$. En la figura IV-23 se muestran estos valores de intensidad normalizados por el valor obtenido en ausencia de vesículas. 

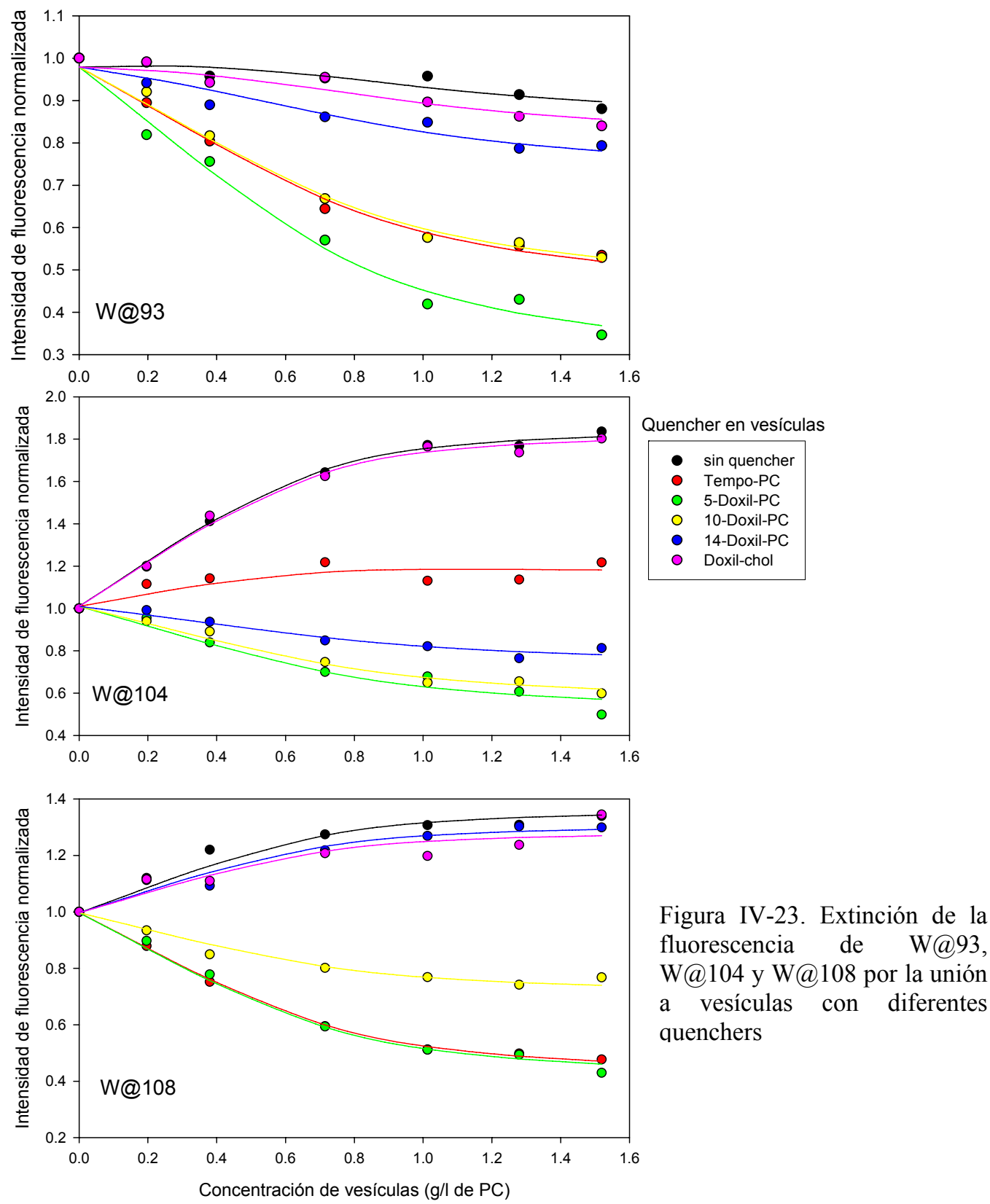

Tal como se observó en el experimento descripto en el punto anterior, esta figura muestra claramente que en ausencia de quencher la intensidad de fluorescencia de W@93 disminuye por el agregado de vesículas, mientras que aumenta considerablemente para W@104 y W@108. También puede observarse que la presencia de 3- $\beta$-Doxil-colestano en las vesículas prácticamente no tiene efecto sobre la intensidad de fluorescencia de ninguna de las 3 mutantes estudiadas. En cambio, la presencia en las vesículas de Tempo-PC o de los n-doxil-PC afecta de manera diferencial a la fluorescencia de las mutantes. Para la mutante W@93, la eficiencia de quenching sigue el orden: 5-Doxil-PC $>$ Tempo-PC $\approx 10$-Doxil-PC $>14$-Doxil-PC. Para 
W@104 el orden fue: 5-Doxil-PC $\approx$ 10-Doxil-PC > 14-Doxil-PC > Tempo-PC; mientras que para W@108 fue: Tempo-PC $\approx$ 5-Doxil-PC > 10-Doxil-PC > 14-DoxilPC. La simple inspección de estos datos indica que el Trp de W@93 se localiza en la bicapa lipídica a una profundidad aproximadamente similar a la del 5-Doxil-PC, mientras que el Trp de W@104 está localizado a mayor profundidad (aproximadamente entre 5- y 10-Doxil-PC) y el Trp de W@108 más superficialmente (aproximadamente entre Tempo-PC y 5-Doxil-PC).

La localización de los residuos Trp de una proteína o péptido en una bicapa lipídica puede ser estimada con bastante precisión mediante el método "Parallax" desarrollado por Chattopadhyay y London (Chattopadhyay and London, 1987) y que se describe más abajo. Para poder aplicar este método a la situación actual, es necesario previamente estimar la intensidad de fluorescencia relativa (tanto en ausencia como en presencia de los "quenchers") cuando el 100\% de la proteína está unida a las vesículas. Esto es, se necesita extrapolar los datos de la figura IV-23 a concentración infinita de vesículas. Teniendo en cuenta que la unión de la proteína a las vesículas afectará al equilibrio monómero-oligómero, puede asumirse que la intensidad de fluorescencia normalizada total (Fn) sigue la relación:

$\mathrm{o} \quad \mathrm{Fn}=\mathrm{fb}$ Feb $+\mathrm{fm} \mathrm{Fem}+(1-\mathrm{fb}-\mathrm{fm})$ Feo

donde $\mathrm{fb}$ es la fracción de proteína unida a membrana, fm es la fracción de proteína libre en estado monomérico y fo la fracción de proteína libre en estado oligomérico. Feb, Fem y Feo son respectivamente las intensidades de fluorescencia específicas (o por unidad de concentración) para la proteína unida a membrana, monómerica y oligomérica.

Para la distribución de la proteína libre en solución entre monómeros y oligómeros se asumió el tercer modelo de los utilizados en la interpretación de los datos de la sección 2 a (figura 11), aunque teniendo en cuenta que sólo una fracción de la proteína total (igual a 1-fb) interviene en este equilibrio. Así, fm estará dado por:

$$
\mathrm{fm}=(1-\mathrm{fb}) /(1+\mathrm{K}[\mathrm{Pt}](1-\mathrm{fb})),
$$

donde $\mathrm{K}$ es la constante de equilibrio para el proceso de oligomerización en solución ya definida en la sección 2a y apéndice I.

Considerando un equilibrio simple para la unión de la proteína a las vesículas, fb estará dada por la solución con sentido físico de:

$$
\mathrm{fb}=\left((\mathrm{Kd}+\mathrm{Pt}+\mathrm{N} * \mathrm{Vt}) \pm \operatorname{sqrt}\left((\mathrm{Kd}+\mathrm{Pt}+\mathrm{N} * \mathrm{Vt})^{\wedge} 2-4 *(\mathrm{Pt} * \mathrm{~N} * \mathrm{Vt})\right)\right) /(2 * \mathrm{Pt})
$$


donde $\mathrm{Kd}$ es la constante de disociación, Pt es la concentración de proteína total, $\mathrm{N}$ es el número de sitios de unión por unidad de concentración de lípido, y Vt es la concentración de vesículas.

La combinación de las ecuaciones g), h) e i) fue ajustada mediante regresión no lineal a los datos experimentales mostrados en la figura IV-23. Para ello, el valor de la constante de equilibrio del proceso de oligomerización $(\mathrm{K})$, así como los valores correspondientes a la fluorescencia específica de monómeros (Fem) y oligómeros (Feo) en solución fueron fijados en los valores que se obtuvieron del experimento descripto en la sección 2a (fig IV-22) y que se indican en la tabla 5. Con estos parámetros fijos, el ajuste a los datos de la figura IV-23 permitió estimar los valores de Feb en ausencia y presencia de los distintos quenchers, así como también el valor de la constante de disociación $(\mathrm{Kd})$ y el número de sitios por unidad de concentración de lípido $(\mathrm{N})$. El ajuste se realizó para estimar un único valor de $\mathrm{Kd}$ y $\mathrm{N}$, asumiendo que éstos no son afectados por la presencia de los quenchers ni por las mutaciones en apoA-I. Los parámetros obtenidos son indicados en la tabla 5 y las funciones ajustadas están representadas por las líneas mostradas en la figura 12. Los valores obtenidos para $\mathrm{Kd} \mathrm{y}$ $\mathrm{N}$ son del mismo orden que los obtenidos por Yokoyama (Yokoyama et al., 1980) para la unión de apoA-I a vesículas de PC de huevo / colesterol (4/1) 
Tabla IV-5. Parámetros fijos usados en el ajuste no lineal de la combinación de las ecuaciones (g), (h) e (i) a los datos experimentales de la figura 12, y parámetros variables obtenidos de dicho ajuste. Los parámetros fijos se obtuvieron del ajuste de la combinación de las ecuaciones (a) y (f) a los datos de la figura IV-22 (ver sección 2a) previamente normalizados a un valor de 1 para $[\mathrm{Pt}]=0,1 \mathrm{~g} / 1$ (la que se usó en el experimento de fig IV-23)

\begin{tabular}{|c|c|c|c|}
\hline \multicolumn{4}{|l|}{ Parámetros fijados } \\
\hline \multicolumn{2}{|l|}{ Mutante } & Fem & Feo \\
\hline \multicolumn{2}{|l|}{ W@93 } & 1,92 & 0,80 \\
\hline \multicolumn{2}{|l|}{ W@104 } & 1,66 & 0,89 \\
\hline \multicolumn{2}{|l|}{ W@108 } & 1,17 & 0,96 \\
\hline \multicolumn{2}{|l|}{$\mathrm{K}\left(\mathrm{g}^{-1} \mathrm{l}\right)$} & 52,8 & \\
\hline \multicolumn{4}{|c|}{ Parámetros variables obtenidos del ajuste } \\
\hline Mutante & $\begin{array}{c}\text { Tipo de quencher en } \\
\text { vesículas }\end{array}$ & Feb & $\begin{array}{l}\text { Eficiencia de quenching } \\
\qquad(\mathrm{F} / \mathrm{Fo})\end{array}$ \\
\hline W@93 & sin quencher & $0,824 \pm 0,018$ & \\
\hline W@93 & Tempo-PC & $0,409 \pm 0,027$ & 0,497 \\
\hline W@93 & 5-doxil-PC & $0,242 \pm 0,030$ & 0,294 \\
\hline W@93 & 10-doxil-PC & $0,419 \pm 0,026$ & 0,508 \\
\hline W@93 & 14-doxil-PC & $0,696 \pm 0,021$ & 0,845 \\
\hline W@,93 & Doxil-colestano & $0,779 \pm 0,019$ & 0,945 \\
\hline W@104 & sin quencher & $1,847 \pm 0,025$ & \\
\hline W@104 & Tempo-PC & $1,155 \pm 0,015$ & 0,625 \\
\hline W@104 & 5-doxil-PC & $0,482 \pm 0,024$ & 0,261 \\
\hline W@104 & 10-doxil-PC & $0,536 \pm 0,023$ & 0,290 \\
\hline W@104 & 14-doxil-PC & $0,714 \pm 0,020$ & 0,386 \\
\hline W@104 & Doxil-colestano & $1,826 \pm 0,024$ & 0,988 \\
\hline W@108 & sin quencher & $1,366 \pm 0,018$ & \\
\hline W@108 & Tempo-PC & $0,406 \pm 0,023$ & 0,297 \\
\hline W@108 & 5-doxil-PC & $0,395 \pm 0,023$ & 0,289 \\
\hline W@108 & 10-doxil-PC & $0,702 \pm 0,018$ & 0,514 \\
\hline W@108 & 14-doxil-PC & $1,310 \pm 0,017$ & 0,959 \\
\hline W@108 & Doxil-colestano & $1,285 \pm 0,017$ & 0,941 \\
\hline $\mathrm{Kd}\left(\mathrm{g}^{-1} \mathrm{l}\right)$ & & $0,0125 \pm 0,004$ & \\
\hline $\mathrm{N}(\mathrm{mol}$ prot $/ \mathrm{mol} \mathrm{PC})$ & & $0,127 \pm 0,006$ & \\
\hline
\end{tabular}

De los valores fluorescencia específica para la proteína unida a membrana (Feb), se estimaron las eficiencias de quenching por la relación de Feb en presencia del quencher a aquella en ausencia del mismo (F/Fo), datos que también se indican en la 
tabla 5. Estos valores fueron entonces utilizados para estimar la profundidad a la que se localizan los residuos Trp de las mutantes en la bicapa lipídica mediante el método de Parallax. Según Chattopadhyay y London (Chattopadhyay and London, 1987), F/Fo está determinado por:

$$
\mathrm{F} / \mathrm{Fo}=\mathrm{e}^{\pi \mathrm{C}\left((\mathrm{Lc}-\mathrm{Zc})^{2}+\mathrm{X}^{2}-\mathrm{Rc}^{2}\right)} \quad \text { para }\left(\mathrm{X}^{2}+(\mathrm{Lc}-\mathrm{Zc})^{2}\right)^{1 / 2} \leq \mathrm{Rc}
$$

donde Rc es el radio del círculo alrededor del quencher paramagnético en el que la extinción de fluorescencia es efectiva, $X$ es la distancia lateral mínima a la que fluoróforo y quencher pueden aproximarse, Lc y Zc son las distancias del centro de la bicapa lipídica en la que se ubican el quencher y el fluoróforo respectivamente, y $\mathrm{C}$ es la concentración de quencher en moléculas por unidad de área. Esta relación se cumplirá siempre que la distancia entre fluoróforo y quencher sea menor al radio crítico Rc, en caso contrario no existirá quenching y F/Fo será igual a 1. En el caso en que no exista restricción para el acercamiento lateral entre fluoróforo y quencher (como sería de esperar en el caso que los Trp se encuentren totalmente expuestos a los lípidos de la membrana), $\mathrm{X}$ será igual a 0 .

En cualquier caso, es necesario conocer los valores de Rc (o Rc y X) para poder estimar la profundidad de localización del fluoróforo $(\mathrm{Zc})$ conociendo la localización del quencher (Lc) y su eficiencia de quenching. Una solución generalmente utilizada para independizarse de Rc (y X) es usar la relación de eficiencia de quenching obtenida por dos quenchers de diferente localización como fue descripto por Chattopadhyay y London (Chattopadhyay and London, 1987). Otra estrategia que utilizamos aquí fue ajustar por regresión no lineal la ecuación (j) a los datos experimentales obtenidos con todos los quenchers. Esto permitió la estimación directa de los valores de $\mathrm{X}^{2}-\mathrm{Rc}^{2}$ (o de Rc si se asume $\mathrm{X}=0$ ). También esta estrategia permite independizarse de conocer con precisión la concentración del quencher por unidad de area, la que no es simple de estimar en sistemas de mezclas de fosfolípidos con colesterol debido al efecto condensante de este último. En la figura IV-24 se muestran los datos de F/Fo en función de la distancia del quencher al centro de la bicapa para las tres mutantes. Sólo los datos de Doxil-colestano fueron omitidos del análisis ya que no hay en la literatura estimaciones precisas de su localización en la membrana. Las líneas de la figura IV-24 representan las funciones ajustadas, y los parámetros obtenidos del ajuste son indicados en la tabla IV-6. 


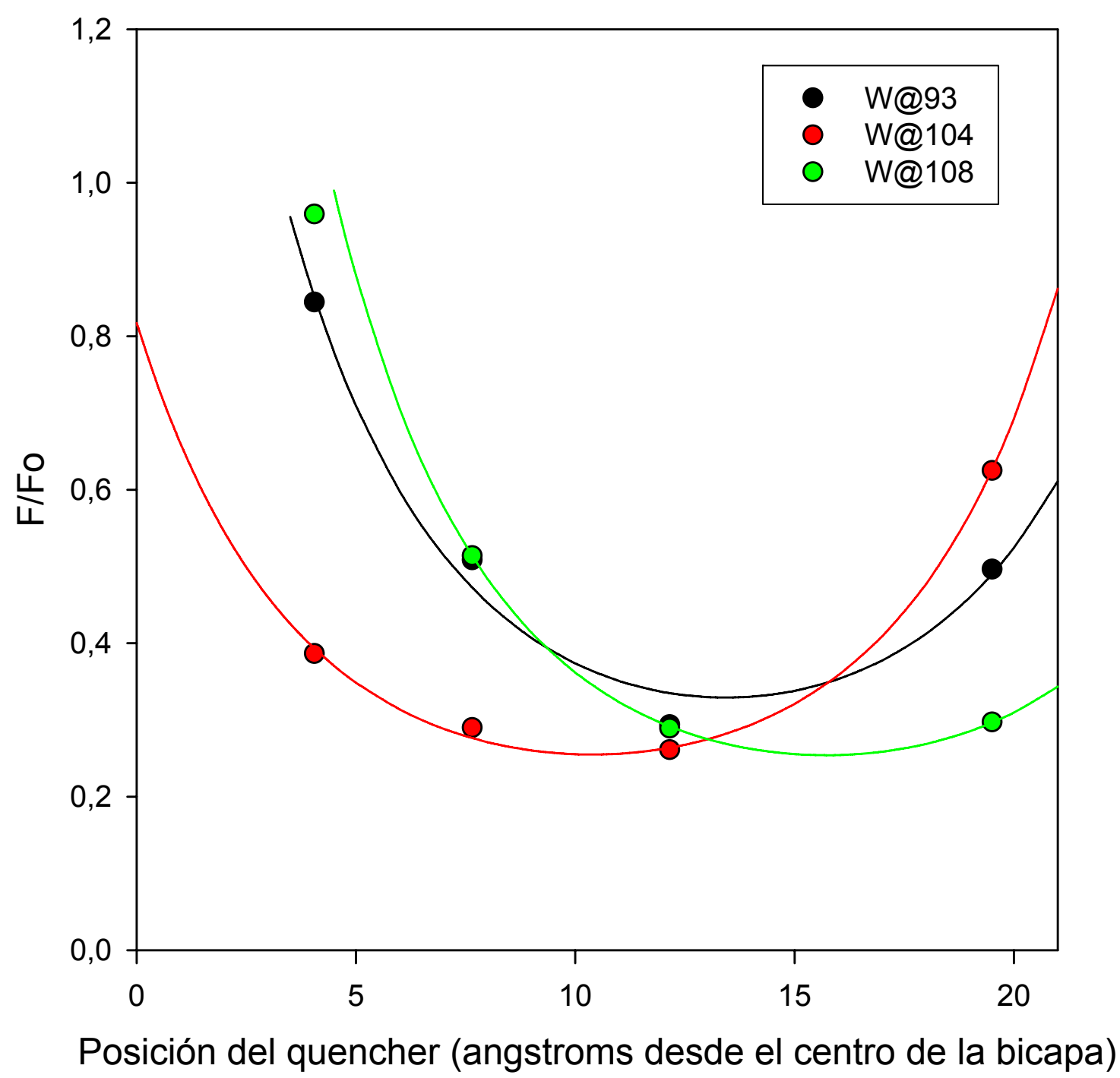

Figura IV-24. Dependencia de la eficiencia de extinción de la fluorescencia de las mutantes W@93, W@104 y W@108 por quenchers localizados a diferente profundidad en la bicapa lipídica. Los puntos son los valores de F/Fo de la tabla 6 graficados en función de la localización del quencher. Las líneas son el representan la función (j) ajustada a los datos experimentales.

Tabla IV-6: Estimaciones de la profundidad de localización en la bicapa lipídica de los Trp de W@93,W@104 y W@108 usando ajuste por regresión no lineal de la ecuación (j) a los datos de figura IV-24. 


\begin{tabular}{|c|c|c|c|c|c|c|}
\hline \multicolumn{7}{|c|}{$\begin{array}{l}\text { Parámetros conocidos: } \\
\text { Distancia de los quenchers del centro de la bicapa en angstroms (Lc) }{ }^{\text {(a) }}\end{array}$} \\
\hline Tempo-PC & \multicolumn{2}{|c|}{ 5-doxil-PC } & \multicolumn{2}{|c|}{ 10-Doxil-PC } & \multicolumn{2}{|c|}{ 14-doxil-PC } \\
\hline 19,5 & \multicolumn{2}{|c|}{12,15} & \multicolumn{2}{|l|}{7,65} & \multicolumn{2}{|c|}{4,05} \\
\hline \multicolumn{7}{|c|}{ Parámetros estimados: } \\
\hline Mutante & $\begin{array}{c}\mathrm{C}^{(\mathrm{b})} \\
\left.\text { (moléculas } / \AA^{2}\right)\end{array}$ & $\begin{array}{l}\text { Zc } \\
(\AA)\end{array}$ & $\begin{array}{l}\mathrm{X}^{2}-\mathrm{Rc}^{2(\mathrm{c})} \\
\left(\AA^{2}\right)\end{array}$ & & $(\AA)$ & $\begin{array}{l}\mathrm{X}^{(\mathrm{e})} \\
(\AA)\end{array}$ \\
\hline W@93 & \multirow{3}{*}{$0,0034 \pm 0,0003$} & $13,43 \pm 0,28$ & $102,9 \pm 6,7$ & & $4 \pm 0,33$ & 6,4 \\
\hline W@104 & & $10,38 \pm 0,32$ & $126,5 \pm 8,8$ & & $25 \pm 0,39$ & 4,2 \\
\hline W@108 & & $15,72 \pm 0,53$ & $126,9 \pm 11,8$ & & $26 \pm 0,52$ & 4,1 \\
\hline
\end{tabular}

(a) El valor de Lc para Tempo-PC fue tomado del trabajo de Chattopadhyay y London. Los valores para 5- y 10-doxil-PC fueron los reportados por los mismos autores (Chattopadhyay and London, 1987). El valor de Lc para 14-Doxil-PC se estimó considerando que la distancia al centro de la bicapa disminuye en 0,09 $\mathrm{nm}$ por cada átomo de $\mathrm{C}$ como fue también reportado por estos autores

(b) El análisis por regresión se realizó conjuntamente a los datos de todas las mutantes y quenchers, lo que permitió estimar la concentración de quencher (C) asumiéndola idéntica para todas las muestras.

(c) Los valores de $\mathrm{X}^{2}-\mathrm{Rc}^{2}$ fueron estimados directamente por la regresión.

(d) Los valores de Rc indicados fueron obtenidos asumiendo que no hay restricción para el acercamiento lateral entre el quencher y los $\operatorname{Trp}($ esto es $\mathrm{X}=0$ ).

(e) Los valores indicados para X se obtuvieron asumiendo para Rc un valor de $12 \AA$ como reportado para estos quenchers (Chattopadhyay and London, 1987)

La concentración de quencher por unidad de área (C) obtenida del ajuste concuerda bastante bien con la que puede ser estimada considerando la relación molar de quencher usada en el experimento y un área molecular para la PC algo condensada por la presencia del colesterol. Los valores de $\mathrm{X}^{2}-\mathrm{Rc}^{2}$ obtenidos también están en el rango esperado de acuerdo a los datos de la literatura (Chattopadhyay and London, 1987). Es de notar, sin embargo, que el valor que se obtuvo para la mutante W@93 es sensiblemente menor que el obtenido para las otras dos mutantes. Cómo para un dado 
par de quencher-fluoróforo no hay motivos aparentes para que Rc no se mantenga constante, es razonable atribuir éste cambio a una diferente accesibilidad lateral del quencher al fluoróforo que es muy factible de ocurrir en proteínas. En la tabla 6 se muestra una estimación de los valores de $\mathrm{X}$ asumiendo un valor razonable (de $12 \AA$ ) para Rc. Aunque estos datos distan mucho de ser precisos debido a la imposibilidad de estimar ambos parámetros independientemente, indican un menor grado de accesibilidad de los quenchers al Trp de W@93 que a los Trp de las otras dos mutantes. Esto concuerda con la observación (ver sección 2b) que la emisión del Trp de W@93 presenta un corrimiento al rojo y una disminución en rendimiento cuántico cuando esta proteína se encuentra en la membrana. Ambos datos sugieren que el Trp de esta mutante se encuentra relativamente menos accesible al entorno lipídico que los Trp de W@104 y W@108.

Independientemente de la accesibilidad lateral, los datos de la tabla IV-6 descartan que las hélices 3 y 4 de apoA-I se inserten en la membrana con su eje largo paralelo a la superficie de la membrana. Estos datos indican una localización más bien superficial para el residuo 108, mientras que el residuo 104 se localiza más profundamente, y a una distancia de aproximadamente una vuelta de hélice del residuo 108. Esto indica fuertemente que la hélice 4 de apoA-I se inserta en la membrana con su eje prácticamente perpendicular a la superficie de la bicapa lipídica.

Por otro lado, el residuo 93 de la hélice 3 se localiza a una profundidad intermedia entre los residuos 104 y 108 de la hélice 4 vecina, lo que indica que existe un giro, muy probablemente alrededor de prolina 99, separando ambas hélices; y que la hélice 3 se encuentra también perpendicular a la superficie de la membrana y antiparalela a la hélice 4 . 


\section{2.d) Configuración de apoA-I en complejos lipoproteicos discoidales. Evidencias de que la configuración es dependiente del método de reconstitución}

La formación de complejos discoidales de apoA-I con fosfolípidos es muy eficiente cuando, como se mencionó previamente, la apoA-I interacciona con membranas multilamelares de determinados fosfolípidos como DMPC a la temperatura de transición de fase. Esto resulta en una rápida micelización y formación de partículas discoidales, cuyo tamaño depende de la relación inicial de lípidos a proteína ( $\mathrm{Li}$ et al., 2004). El inconveniente de este método es que puede ser aplicado a unos pocos fosfolípidos que sufren la transición de fase a temperaturas superiores al punto de fusión del agua e inferiores a la temperatura en que la proteína desnaturaliza. Otra forma muy difundida de obtener complejos discoidales es por medio de la técnica de diálisis con detergente como colato de sodio (Matz and Jonas, 1982a). Para ello se obtienen vesículas multilamelares de un fosfolípido o mezclas de ellos, se las incuba con un detergente fácilmente dializable como el colato de sodio, y por ultimo se incuba con la apoA-I ó con cualquiera de sus mutantes. Al eliminar el detergente por diálisis, se forman los discos de composición lipídica similar a la de las vesículas iniciales (Jonas et al., 1989).

Una pregunta planteada en este trabajo, fue si estos dos procedimientos resultan en la misma configuración de apoA-I en los complejos discoidales. Este interrogante es de gran importancia, ya que estas partículas se utilizan como modelos de las HDL discoidales naturales, las que como se mencionó juegan un rol primordial en la etapa inicial del transporte reverso de colesterol (pre $\beta H D L)$. Por la literatura presente, no quedan dudas respecto a que existen al menos 2 moléculas de apoA-I por complejo y los modelos más ampliamente aceptados indican que éstas se ubican con el eje mayor de las hélices perpendicular a las cadenas hidrocarbonadas de los lípidos (Silva et al., 2005b). Con el fin de responder esta pregunta, se prepararon $\mathrm{y}$ analizaron complejos lipoproteicos por medio de las dos técnicas, utilizando ya sea mutantes de Trp único ó la apoA-I obtenida de suero. Para la técnica de reconstitución por micelización a la Tm, se incubó apoA-I con DMPC por 8 hs a $24{ }^{\circ} \mathrm{C}$ a una relación molar ya sea de apoA-I ó de sus mutantes respecto a lípidos de $1 / 40$; los discos formados con colato fueron preparados a una relación molar proteína/lípido/colato de 1/40/60, preparando primero las vesículas multilamelares de DMPC, luego incubando con colato a $4{ }^{\circ} \mathrm{C}$, agregándose finalmente la apoA-I o sus mutantes, para luego dializarlo contra buffer fosfato $25 \mathrm{mM}$ 
$\mathrm{pH}$ 7.4.. Por último a los discos formados por estas dos técnicas se los sometió a cuatro ciclos de una hora cada uno, a las temperatura de $20-24-37{ }^{\circ} \mathrm{C}$ (una hora a cada temperatura $\mathrm{x} 4$ veces) Como en primera instancia se obtienen poblaciones de partículas con la misma cantidad de proteína pero de diferente cantidad de lípidos el objetivo de esta etapa es lograr con los ciclos de temperaturas, obtener tamaños de discos que dependan solamente de la relación Lip/Prot.(Li et al., 2004); esto también se puede lograr incubando las partículas durante 7 dias a $4{ }^{0} \mathrm{C}$. En todos los casos la concentración final de apoA-I ó W@n fue de $0.2 \mathrm{mg} / \mathrm{ml}$.

La conformación de la proteína en los complejos reconstituidos por los diferentes métodos mencionados se analizó mediante dos diseños experimentales: 1) mediante fluorescencia, determinando la eficiencia de homotransferencia de energía entre los residuos Trp de ambas proteínas en cada partícula, en los complejos formados con W@n (donde $n=104$ ó 108). La eficiencia de transferencia se detectó midiendo la anisotropía de fluorescencia excitando a $295 \mathrm{~nm}$. 2) Mediante espectrometría de masa: en este caso se reconstituyeron partículas usando apoA-I sérica, se hicieron reaccionar con un agente entrecruzante hidrófobico específico para grupos aminos, el Dithiobis (succinimidyl)propionate (DSP) por 20 minutos a temperatura ambiente a una relación molar 10/1 croslinker/apoA-I e interrumpiendo la reacción con buffer Tris 1M pH 7,4. Luego se deslipidizó con guanidina, se separaron los monómeros de dímeros por cromatografía líquida rápida de proteínas (FPLC) y se tripsinizaron. Una alícuota del tripsinizado se separó por HPLC (cromatografía líquida de alta performance) de fase reversa y otra se analizó por medio de espectrometría de masa MALDI-TOF (del inglés Matrix-Assisted Laser Desorption/Ionization Time-Of-Flight) en el Department of Biochemistry \& Molecular Biology, Oklahoma State University.

Los estudios de fluorescencia de los discos reconstituidos con los mutantes puntuales de Trp son resumidos en la tabla IV-7:

\begin{tabular}{|l|c|c|c|}
\hline & $\lambda \max (\mathrm{nm})$ & Intensidad Relativa & $\begin{array}{l}\text { Anisotropía }(\lambda \text { ex.295 } \\
\mathrm{nm})\end{array}$ \\
\hline W@104 s/líp. & 345 & 600 & 0.069 \\
W@108 s/líp. & 339 & 1750 & 0.086 \\
& & & 0.117 \\
\hline W@104/DMPC/colato & 341 & 2332 & 0.116 \\
W@108/DMPC/colato & 338 & 4196 & 0.017 \\
\hline W@104/DMPC & 341 & 1447 & 0.049 \\
W@108/DMPC & 340 & 1868 & \\
\hline
\end{tabular}

Tabla IV-7: caracteristicas de espectros de fluorescencia de partículas dicoidales obtenidas por dos técnicas diferntes 
Se puede observar que el entorno del residuo de Triptofano en la posición 108 no sufre cambios significativos en las partículas discoidales formadas por las dos técnicas respecto al estado libre. En cambio el Trp 104 se encuentra más protegido del medio acuoso al unirse a lípidos.

Se observa también una notoria disminución en intensidad y anisotropía de Trp 104 y Trp 108 en discos preparados por reacción directa en comparación con aquellos preparados con colato, atribuyéndose este fenómeno a homotransferencia de energía de resonancia (Trp-Trp), por lo que los datos sugieren que el arreglo de apoA-I en los discos depende del método de reconstitución e indican una menor distancia promedio entre las hélices 4 de las dos moléculas de apoA-I cuando los discos son preparados por reacción espontánea con vesículas de DMPC.

Como se mencionó arriba, otra forma de estudiar la conformación de la apo en complejos reconstituidos fue mediante el uso de agentes entrecruzantes y tripsinolísis de la apoA-I nativa. Una vez reconstituidas las partículas por ambos métodos se analizaron por gel en condiciones nativas (fig. IV-25)

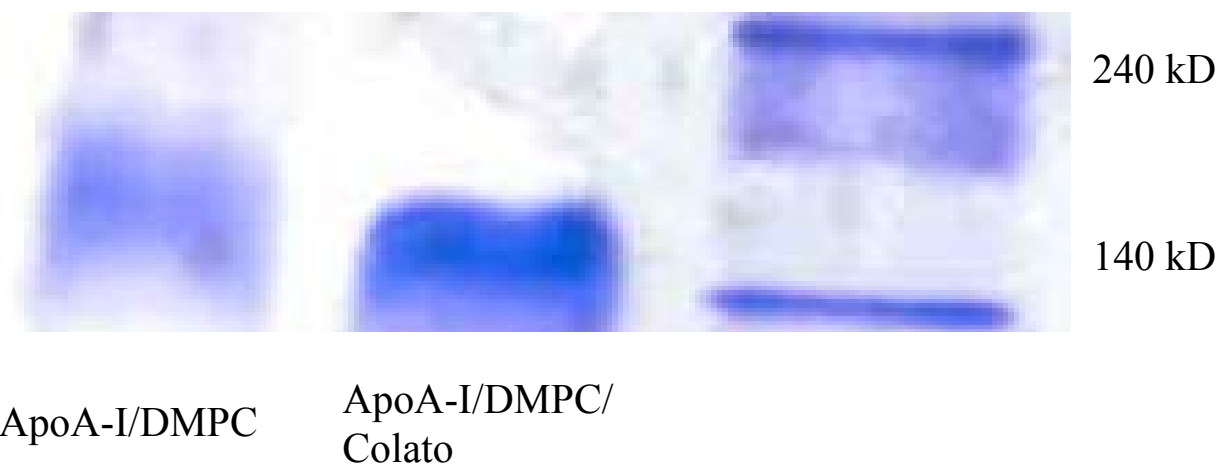

Fig. IV-25: Gel nativo en gradiente $4-24 \%$ de partículas de dHDL

Se ve en el gel que el tamaño de las partículas es similar cuando son utilizadas las mismas relaciones fosfolípidos/ proteínas.

Estas partículas fueron tratadas con el agente entrecruzante lipofilico DSP, y posteriormente se verificó la obtención de dímeros por electroforesis en gel de SDSPAGE $12 \%$ 
$60 \mathrm{kD}$

Dímeros de

ApoA-I

ApoA-I/DMPC

ApoA-I/DMPC/Colato

Fig. IV-26: Gel de SDS-PAGE en donde se muestra los dímeros de apoA-I obtenidos a partir de las diferentes tipos de partículas por entrecruzamiento covalente con el reactivo DSP.

Como se menciona mas arriba los dímeros fueron separados por FPLC y Tripsinisados, una alícuota de cada muestra fue resuelta por HPLC en gradiente de agua/aceto-nitrilo (90-10\% a tiempo cero a 10-90\% a los 60 minutos en agua acetonitrilo, el flujo utilizado fue de $500 \mu \mathrm{l} / \mathrm{min}$ ) observándose que los perfiles de elusión de las mismas no fueron iguales (Fig.IV-27a y IV-27b). Si bien todos los picos observados en la muestra correspondiente a los discos preparados por la reacción directa también se detectan en la muestra de los discos preparados por diálisis con colato, en esta última también se observan varios picos adicionales. 
Fig. IV-27a: Perfil de elusión en HPLC (por DO a $220 \mathrm{~nm}$ ) luego de la tripsilnolisis de los dimeros obtenidos a partir de los diferentes tipos de partículas discoidales
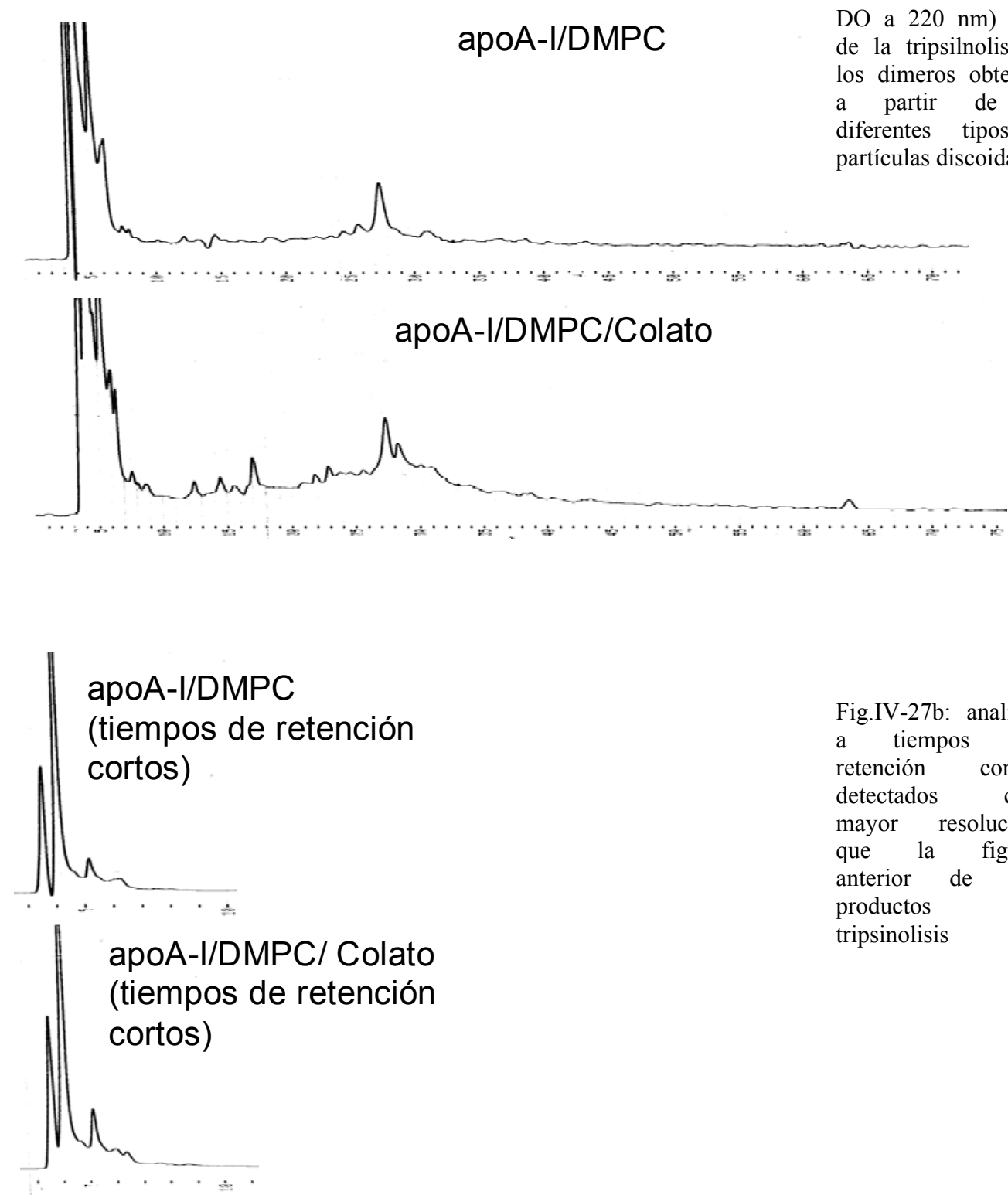

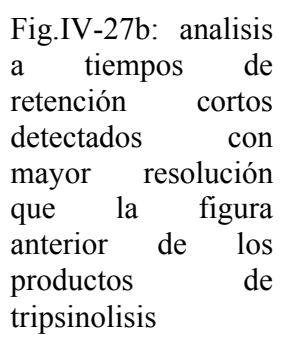
tripsinolisis

El análisis del producto de tripsinólisis por MALDI-TOF rindió resultados similares a los encontrados en los perfiles de HPLC en lo que respecta a que se obtienen péptidos a partir de apo en las partículas formadas con colato que no se obtienen cuando las partículas son formadas por interacción directa. (ver fig. IV-28a, IV-28b). 

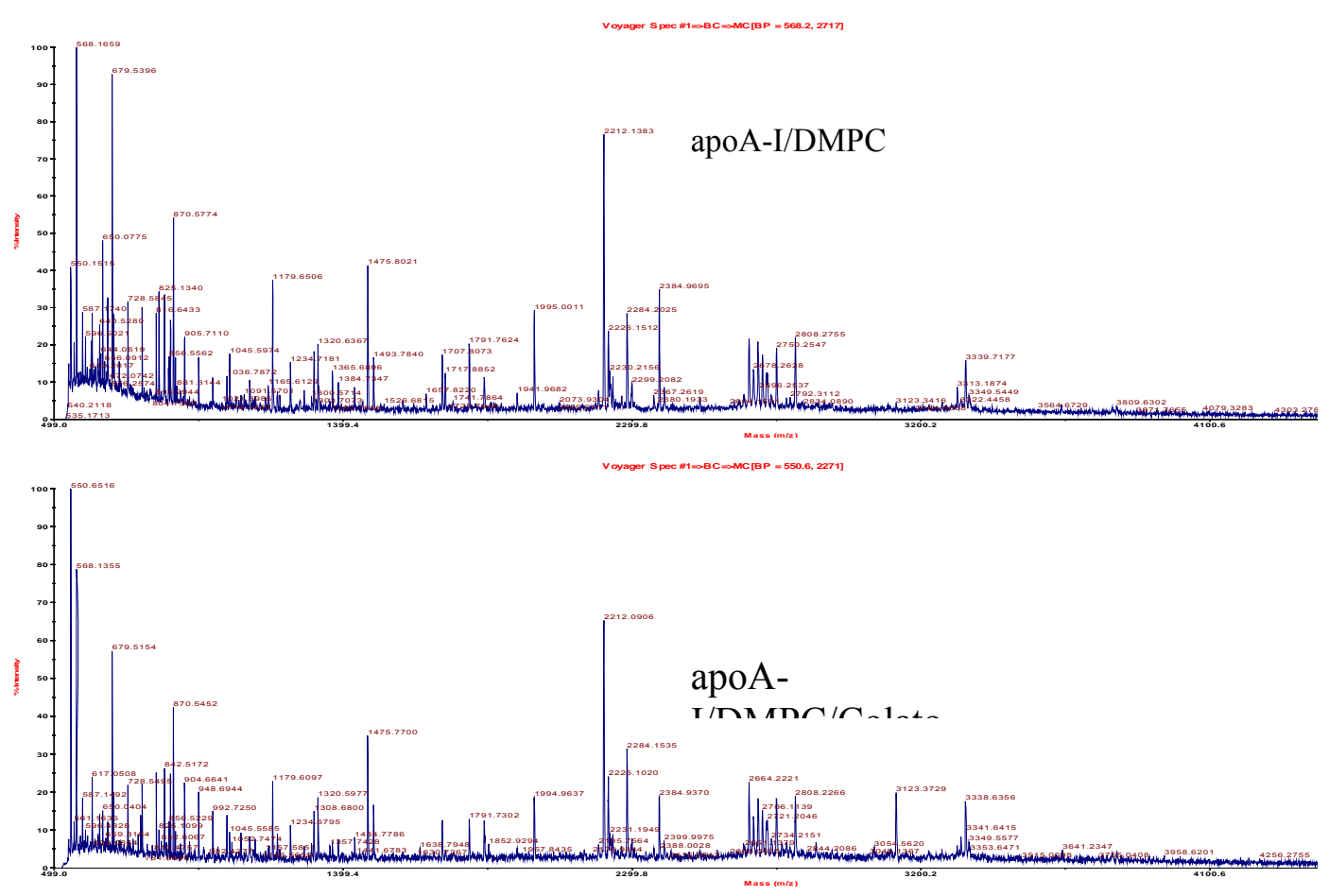

Fig. IV-28a: analisis de los pesos moleculares de los péptidos obtenidos de los productos de tripsinolisis de los dimeros provenientes de los discos formados por las dos trécnicas mencionadas

Al hacer la diferencia de los espectros se observan marcadamente la presencia de picos distintivos en la muestra con colato.

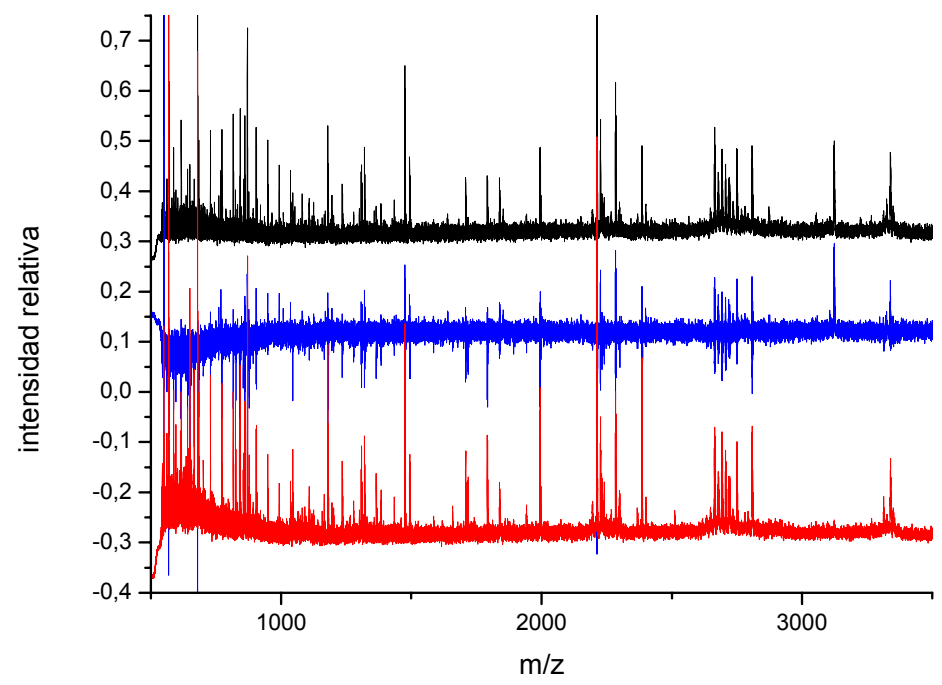

Fig.IV-28b:

diferencia de los pesos moleculares de los péptidos obtenidos de discos formados por las dos técnicas: en negro, los obtenidos con colatos; rojo: obtenidos por micelización directa; y en azul la diferencia 
Tanto los resultados de los experimentos con el agente entrecruzante como los obtenidos por los estudios de fluorescencia con las mutantes W@104 y W@108 indican claramente que la configuración de la apoA-I en los discos resultantes de la reacción directa con vesículas de DMPC a la temperatura de transición difiere de aquella en los discos que resultan por diálisis con colato.

Las HDL discoidales recontituídas con colato, tanto de apoA-I como de otras apolipoproteínas intercambiables, han sido extensivamente estudiadas por diferentes técnicas. En varios de estos estudios se ha detectado la coexistencia de configuraciones alternativas. En base a resultados de mediciones de distancias por transferencia de energía en mutantes con inclusión de un residuo de cisteína y específicamente marcadas con fluoróforos, Tricerri y colaboradores (Tricerri et al., 2001) propusieron el modelo de la hebilla (ver Introducción). Los datos, sin embargo, no pueden ser compatibilizados con una configuración única, por lo que estos autores propusieron la coexistencia de dos configuraciones de la hebilla (cabeza-cabeza y cabeza-cola). En discos de apolipoforina III preparados de la misma manera, Garda y col. (Garda et al., 2002) también detectaron la coexistencia de al menos dos configuraciones. Más recientemente, mediante el mapeo de los residuos de lisina cercanos entre sí usando agentes entrecruzantes, Silva y colaboradores (Silva et al., 2005b), (Davidson and Silva, 2005) también detectaron dos configuraciones coexistentes en discos de apoA-I, aunque en este caso soportando el modelo del "doble cinturón" (ver Introducción) con las dos moléculas de apoA-I completamente extendidas sobre el borde del disco y antiparalelas entre sí. En una de estas configuraciones (denominada 5/5), quedan enfrentadas las hélices 5 de cada molécula de apoA-I. En la otra (llamada 5/2), la hélice 5 de una molécula queda enfrentada a la hélice 2 de la segunda molécula de apoA-I.

Los resultados presentados en este capítulo sugieren que a diferencia de los discos preparados por diálisis con colato, aquellos que se generan por la reacción directa con DMPC en la temperatura de transición tendrían una única configuración en la que las hélices 4 de cada molécula de apoA-I se encuentran en estrecho contacto entre sí. Esto sería compatible tanto con la "hebilla cabeza-cabeza" como con el "doble cinturón $5 / 2$.

Cómo se detalló anteriormente (sección IV-A), la unión de apoA-I a membranas lipídicas va acompañada de dimerización. Además, la interacción intermolecular entre las repeticiones helicoidales 3 y 4 parece ser importante tanto para la oligomerización en solución (sección IV-C-2b), como también para la dimerización en la membrana 
como lo sugieren los experimentos con AI 77-120 (sección IV-A) No está aún resuelto si es el dímero de apoA-I en solución el que se une directamente a la membrana, o si alternativamente se une primero apoA-I monomérica que posteriormente dimeriza en la membrana. En cualquiera de los casos, sin embargo, es razonable asumir que la formación del dímero en la membrana sea un requisito previo para la reacción de micelización que resulta en la formación de los complejos discoidales. Esta dimerización previa por la interacción intermolecular entre las hélices centrales podría determinar que la proteína presente un única configuración (con las hélices centrales en estrecho contacto entre sí) en los discos resultantes. Esta restricción no existiría cuando los discos son preparados por el método de diálisis con colato, lo que permitiría que la proteína pueda adoptar más de una configuración en los discos (aquellas que se encuentren en un mínimo energético).

Si bien la configuración de apoA-I en las HDL naturales o generadas por la interacción de apoA-I con células no es conocida, estos resultados generan un margen de duda sobre la validez de usar a las HDL reconstituídas por diálisis con detergentes como modelo de las HDL naturales. La misma restricción existente para la generación de discos por la reacción con vesículas de DMPC a la temperatura de transición bien podría existir en el proceso de formación de HDL discoidales que es mediado por el transportador $\mathrm{ABCA} 1$ en las células, aunque la obtención de datos tendientes a resolver este problema requerirá de futuros estudios.

Cabe recordar que el péptido AI 77-120 no resultó eficiente para solubilizar lípidos a la Tm (y por ende en formar partículas lipídicas, pero en cambio formó partículas de alrededor de $67 \mathrm{kD}$, cuando se siguió el protocolo de la formación de discos por diálisis de colato (fig IV-6 sección IV-A).

Todos estos resultados apoyan la hipótesis (que será posteriormente analizada), de que la interacción de la apoA-I con membranas favorece la dimerización de la proteína a partir de su dominio central, y la posterior captación de fosfolípidos, los que puedan ser aceptores de colesterol. 
CAPÍtulO V:

DISCUSIÓN 


\section{Obtención y caracterización de las mutantes}

Para resolver cualquier ensayo experimental es fundamental contar con un sistema de proteínas que sirvan para resolver preguntas concretas. En nuestro caso, como la apoA-I posee 4 residuos de Triptofano (Trp), cualquier medida utilizando las propiedades intrínsecas de este, como ser fluorescencia, daría como resultado un promedio de las características de emisión de todos los residuos. Por tal motivo, para estudiar el entorno de la región central se planificó la construcción de mutantes simples conteniendo un solo residuo Trp en distintas posiciones a lo largo de su secuencia.

La obtención de mutantes de proteínas provenientes de células eucarióticas, y su expresión en bacterias, no es simple. Por empezar, la abundancia de los ARNt que reconocen codones sinónimos difiere entre eucariotes y procariotes, lo que puede traer aparejado una disminución en la eficiencia de expresión. Además, la expresión de proteínas foráneas puede traer aparejado una toxicidad que no es posible predecir en el momento de diseñar o planear dichas mutaciones. (Yadava and Ockenhouse, 2003). Entre otras, estas razones pueden explicar el porqué en algunos casos no se logró la expresión del cDNA mutado.

Asimismo, cuando se obtienen proteínas mutantes en sistema bacterianos, su extracción de las células en muchos casos debe hacerse en condiciones desnaturalizantes, como fue en nuestro caso, debido que la sobreexpresión de las mismas induce su depósito en los cuerpos de inclusión bacterianos. Este paso en muchos sistemas es limitante, principalmente si la proteína es inestable ó sensible a determinadas condiciones. Por suerte, nuestro sistema de expresión es bastante "noble" y se ha logrado obtener apreciable cantidad y buen grado de pureza de las mutantes que expresaron, y en condiciones aptas para realizar los diferentes ensayos proyectados.

Para que estas mutantes de único Trp nos informen sobre la conformación de la proteína nativa, es esencial que las mutaciones no introduzcan grandes cambios (estructurales o funcionales) respecto a la proteína nativa. Por esto, una vez obtenidas las proteínas recombinantes, y luego del corte con la enzima proteolítica igasa y de la confirmación de su pureza y peso molecular mediante SDS-PAGE (como era esperable, todos los mutantes analizados presentaron peso molecular $28 \mathrm{kD}$, correspondiente a la apo madura de 243 aminoácidos), fue fundamental realizar el análisis de la estructura secundaria por dicroísmo circular. Los espectros adquiridos en el UV lejano (entre 195 y $250 \mathrm{~nm}$ ) fueron característicos de proteínas con un alto contenido de $\alpha$-hélices, siendo 
lo máximos y mínimos característicos de la apoA-I (Cho and Jonas, 2000). Esto confirma que las mutantes.W@93,W@104 y W@108, mantienen su estructura secundaria sin alteraciones significativas respecto a la proteína nativa.

Una técnica extensamente utilizada para la caracterización funcional de apoA-I es, como fue mencionada, la medición de la cinética de micelización de partículas multilamelares de DMPC a temperatura de transición de fase. En este caso, las mutantes mostraron una cinética más lenta que la apo Wt (analizado por disminución de turbiedad a $350 \mathrm{~nm}$ ) pero la densidad óptica es la misma al cabo de $8 \mathrm{hs}$ a $24^{0} \mathrm{C}$, dando partículas discoidales del mismo peso molecular luego de los ciclos de temperaturas a las que fueron expuestos. Como todas las mutantes testeadas (incluída W@108 que en su región central conserva la secuencia original) presentan una cinética de micelización más lenta que apoA-I Wt, ésto no se debería a las mutaciones introducidas en la región central sino a aquellas introducidas para eliminar los otros tres Trp. Mutantes similares obtenidos por el Dr W.S. Davidson, presentaron una variación de energía libre de plegamiento ligeramente disminuida cada vez que un Trp fue reemplazado por una Phe (Davidson et al., 1999)

Del análisis de estos datos concluimos que si bien las mutantes reaccionan más lentamente con vesículas de DMPC, la estructura proteica se mantiene inalterada en los complejos lipoproteicos resultantes; y por lo tanto estas mutantes pueden ser utilizadas como modelo en lo estudios conformacionales de apoA-I en los estados libre y unida a lípidos.

Una vez obtenidos los mutantes, nos planteamos el objetivo de caracterizar la participación del dominio central en procesos de adaptación estructural (conformación en los distintos estados), e independencia funcional en la remoción de lípidos. Los datos presentados en este estudio confirman el cambio conformacional que experimenta la apoA-I para adaptarse al microambiente lipídico, y aportan información sobre la participación de la región central de la proteína en las distintas conformaciones: en el estado libre de lípidos, en la interacción con membranas, y en complejos lipoproteicos. 


\section{Conformación de la región central en la proteína libre de lípidos (lipid-free)}

Como se mencionó en la Introducción, la estructura de apoA-I libre fue estudiada por distintas técnicas, pero dada la alta discrepancia que existe entre las estructuras cristalinas, así como entre éstas y los datos de la proteína en solución, es importante profundizar en su caracterización. En particular de la región central que nos interesa.

Si bien en estado fisiológico prácticamente no se detecta apoA-I libre de lípidos, dado que rápidamente se combina con fosfolípidos para formar diferentes tipos de HDL nacientes (Krimbou et al., 2005), in vitro en solución acuosa la apo se encuentra en forma de toroide en donde los dominios $\mathrm{N}$ y C-terminal están muy próximos (Tricerri et al., 2000), (Behling Agree et al., 2002) y en equilibrio entre monómeros y dímeros en concentraciones de $0.1 \mathrm{mg} / \mathrm{ml}$, ú oligómeros de mayor peso molecular dependiendo de la concentración proteica (Cho and Jonas, 2000)

Los espectros de emisión de fluorescencia en solución acuosa de los mutantes que contienen un solo Triptofano en la región central, indican que los residuos en las posiciones 93 y 108 se encuentran en un ambiente hidrofóbico, mientras que el 104 se encontraría en un ambiente más polar. Como era de esperar, la fluorescencia de las tres mutantes se corre a mayores longitudes de onda por la denaturalización con guanidinaHCl 3M. Sorprendentemente, sin embargo, para W@93 y W@104 ésto va acompañado de un aumento en la intensidad de emisión. Ya que además del desplegamiento, la denaturalización también implica seguramente una disrupción de los dímeros $\mathrm{u}$ oligómeros, ésto nos indujo a pensar que el rendimiento cuántico de los Trp de estas mutantes podría estar disminuído por homotransferencia de energía Trp-Trp. Este hecho fue confirmado al medir la intensidad y anisotropía de la fluorescencia de los distintos mutantes en función de la concentración de la proteína (Moens et al., 2004). Se encontró que las tres mutantes, pero especialmente W@93 y W@104, sufren un aumento en la intensidad y anisotropía de fluorescencia a medida que la muestra se diluye, asociándose estos cambios al desplazamiento del equilibrio hacia la forma monomérica al disminuir la concentración proteica. Así, esto indica la existencia de homotransferencia de energía Trp-Trp en los dímeros (u oligómeros) de estas mutantes. Ya que este fenómeno sólo puede ocurrir si la distancia entre los Trp es cercana o inferior a $1 \mathrm{~nm}$, estos resultados indican que el par de hélices 3-4 de apoA-I está comprometido en el proceso de oligomerización, de manera que el par de hélices de una 
molécula de apoA-I interactúa y queda en estrecho contacto con el par de hélices equivalente de la otra molécula en el dímero. Una probable conformación dimérica es esquematizada en la figura V-1, modelada con el programa Movie-Maker (accesible desde la página www.expasy.org), de acuerdo a la estructura cristalina predicha para la apo completa, código de acceso PDB 2AV1, (Ajees et al., 2006)

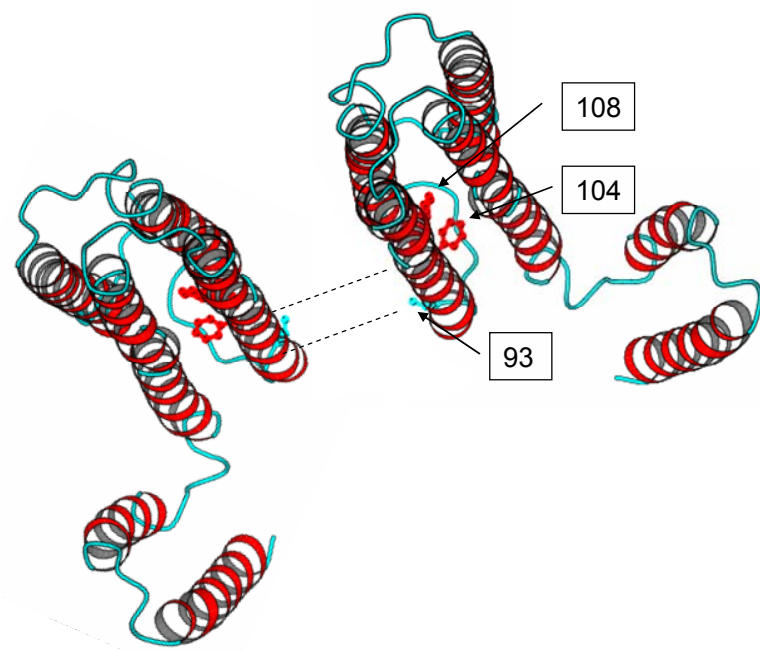

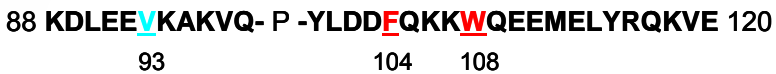

Fig.V-1: Modelado según Movie Maker (www.expasy.org), usando el código de acceso del PDB 2A01 (Ajees et al, 2006) 
La participación del par de hélices Y central en la oligomerización es además soportada por el hecho de que el péptido AI 77-120 también es capaz de dimerizar en solución acuosa. La tendencia a dimerizar de AI 77-120 es sin embargo bastante menor que la de apo A-I, lo que sugiere que otras hélices también podrían participar en el proceso. La relativamente alta estabilidad de AI 77-120 en la forma monomérica podría ser explicada por el menor ancho de las caras hidrofóbicas en relación a las hidrofílicas que presentan las hélices 3 y 4 . Esto permitiría la exclusión de casi la totalidad de los grupos no polares del medio acuoso simplemente por la interacción entre las caras hidrofóbicas de estas hélices como se indica en la figura V-2.

Para la forma dimérica (u oligomérica), se pudo obtener una estimación de las distancias entre los residuos Trp de las 3 mutantes mediante la extrapolación de los datos de intensidad y anisotropía a dilución y concentración infinita (ver sección 2a de resultados). Estas distancias son del orden del ancho del esqueleto de una $\alpha$-hélice: 3,5$5 \AA$ para W@93 y W@104, y algo mayor (5-6,5 Å) para W@108, lo que indica que los pares de hélices 3-4 de cada molécula de apo A-I en el dímero interactúan entre sí por sus caras hidrofóbicas. Un modelo probable que compatibiliza estas distancias es mostrado en la figura V-3a. En el mismo puede observarse que el residuo 104 queda localizado en la interfase entre ambas caras (hidrofílica e hidrofóbica) de la hélice, lo que podría ser la causa del entorno relativamente más polar encontrado para el Trp de W@104 en comparación con las otras mutantes.

\section{Interacción de la apoA-I en estado libre de lípidos con membranas}

Dado que la región central de la apo es candidata a jugar un rol importante en la interacción con membranas, se estudió en este trabajo la participación de este dominio en la interacción con vesículas lipídicas, en situación donde no hay formación espontánea de productos lipoproteicos en un tiempo corto.

a) Análisis estructural:

Los resultados sugieren que la estabilización de la conformación dimérica propuesta para la proteína en solución es favorable a la interacción con membranas. Un rearreglo estructural sería necesario respecto a la estructura de la proteína en solución, como lo indica el hecho de que, si bien el entorno de los residuos 104 y 108 no se modifica drásticamente, el residuo 93 se localiza en un entorno más polar cuando la 
proteína está unida a la membrana. Sin embargo, como indican los datos de dicroísmo circular con el péptido AI 77-120, el proceso de inserción en la membrana no implicaría cambios significativos en la estructura secundaria (aumento de alfa hélice), sino que es favorecido por la adquisición de estructura cuaternaria como se demostró en los ensayos de crosslinking tanto con apoA-I como con AI 77-120. Esto nos permitió postular que el dominio de inserción activo sería un ramillete de hélices intermolecular, formado por los dos pares de hélices Y centrales de la proteína dimérica.

Por otro lado, las mediciones de extinción de la fluorescencia de W@93, W@104 y W@108 con quenchers paramagnáticos localizados a diferente profundidad en la bicapa lipídica de vesículas, nos permitió estimar la profundidad en la que se localizan cada una de las posiciones reportadas por los Trp, y así deducir la topología de inserción del par de hélices 3-4 en la membrana. Por la aplicación del método del "Parallax", se estima una distancia del centro de la bicapa de aproximadamente 13, 10 y $16 \AA$ para los residuos de las posiciones 93, 104 y 108, respectivamente. Estas distancias del centro de la bicapa pueden ser compatibilizadas en el esquema mostrado en la figura V-4a. Considerando que el avance de una $\alpha$-hélice es de 1,5 Å por residuo, la diferencia de $6 \AA$ entre la profundidad de localización de las posiciones 104 y 108 indican que la hélice 4 se inserta verticalmente o con su eje mayor bien perpendicular a la superficie de la membrana. En el caso de la hélice 3, si bien sólo tenemos el dato de la posición del residuo 93, su localización a una profundidad intermedia entre la de los residuos 104 y 108 indican la presencia de un giro (que muy probablemente ocurra en Pro 99) y una disposición antiparalela a la hélice 4.

Dado que como ya mencionamos, las caras hidrofóbicas de las hélices anfipáticas 3 y 4 poseen una superficie relativamente menor que las caras hidrofílicas, la inserción vertical de un único par de hélices interactuando por sus caras hidrofílicas (como mostrado en fig $\mathrm{V}-4 \mathrm{a}$ ) es muy improbable debido a que no podría excluir completamente a los grupos polares de su exposición al entorno hidrofóbico de la membrana. Esta exclusión sí podría lograrse mediante la inserción de un ramillete intermolecular de estas hélices interactuando entre sí por las caras hidrofílicas como se muestra en las figuras V-3b y V- 4b. La ausencia de monómeros de apoA-I o AI 77-120 en el estado unido a membrana es un argumento a favor de esta hipótesis. Esta organización de hélices anfipáticas es encontrada en muchos canales iónicos y transportadores de sustancias polares como los GLUT, aunque en estos casos las hélices atraviesan completamente la membrana. También esta disposición de las hélices fue 
propuesta para el estado insertado en membranas de ectatomin, péptido para el que como se mencionó se predice analogía estructural con la región central de apoA-I. En el caso de apoA-I, no se formaría un canal hidrofílico completo ya que las hélices no atraviesan completamente la membrana. Sin embargo, este "hemicanal" podría explicar el incremento transitorio de permeabilidad al contenido acuoso de vesículas fosfolipídicas que ocurre cuando a éstas se les agrega apoA-I (Tricerri et al., 1998)

Es de notar que el par de hélices Y central no es la única región de apoA-I que interactúa con la membrana. La mayor afinidad por membranas que presenta apoA-I en comparación con el péptido AI 77-120 indica que otras hélices también participan en la unión y contribuyen a la mayor afinidad. Sin embargo, el par de hélices 3-4 sería el único que se insertaría verticalmente en la membrana, lo que explicaría el hecho de que es la única región de apoA-I que es accesible a reactivos fotoactivables localizados profundamente en la bicapa lipídica como el ${ }^{125}$ I-TID/PC (Corsico et al., 2001). El resto de las hélices de apoA-I muy probablemente interactúan horizontalmente con su eje mayor paralelo a la superficie de la membrana, y empotrando la cara hidrofóbica en la bicapa lipídica, como ha sido propuesto en las $\alpha$-HDL esféricas.

Como se puede ver de la comparación de los esquemas V-3a y V-3b, el rearreglo estructural del par de hélices Y central que ocurre en el proceso de inserción en la membrana sería el giro de las hélices por $\sim 180^{\circ}$ de manera que en solución acuosa interactúan por las caras hidrofóbicas y en la membrana por las caras hidrofílicas. Esta reorganización puede explicar el incremento en distancia entre los residuos homólogos y la consecuente disminución en eficiencia de homotransferencia de energía observada paraW@104 y W@108 en presencia de vesículas. La distancia intermolecular entre estos residuos, que es de $\sim 5 \AA$ en solución acuosa como pudo ser determinado aquí, se triplicaría en el estado insertado en la membrana explicando la desaparición del fenómeno de homotransferencia de energía. Según el modelo de fig. V-3b, este incremento en distancia también ocurriría para el residuo 93. Nuestros datos, sin embargo, no pueden negar ni confirmar que esto ocurra como se discutió en el capítulo IV. La mutante W@93 sufre un notable corrimiento de su emisión hacia el rojo indicando que el residuo 93 se encuentra en un entorno más polar cuando la proteína está unida a la membrana. Esto puede ser explicado por su localización en el límite entre ambas caras (hidrofílica e hidrofóbica) de la hélice, lo que podría resultar en una localización muy cercana a los grupos polares (y/o el agua) del interior del "hemicanal". 
También esto explicaría la relativamente menor accesibilidad a los quenchers paramagnéticos lipídicos (Tempo-PC y n-doxil-PC) encontrada para esta mutante en comparaciónconW@104yW@108.

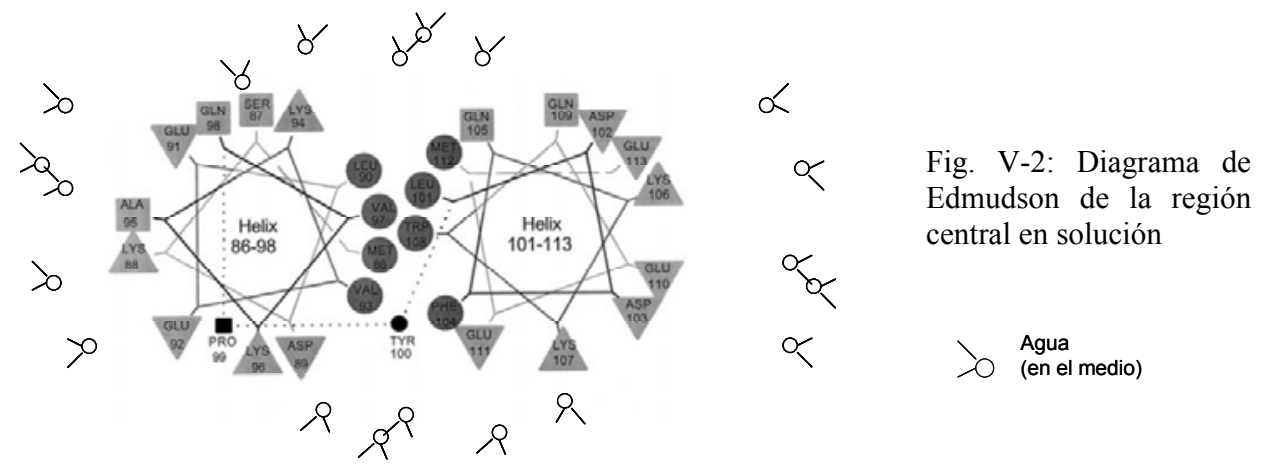

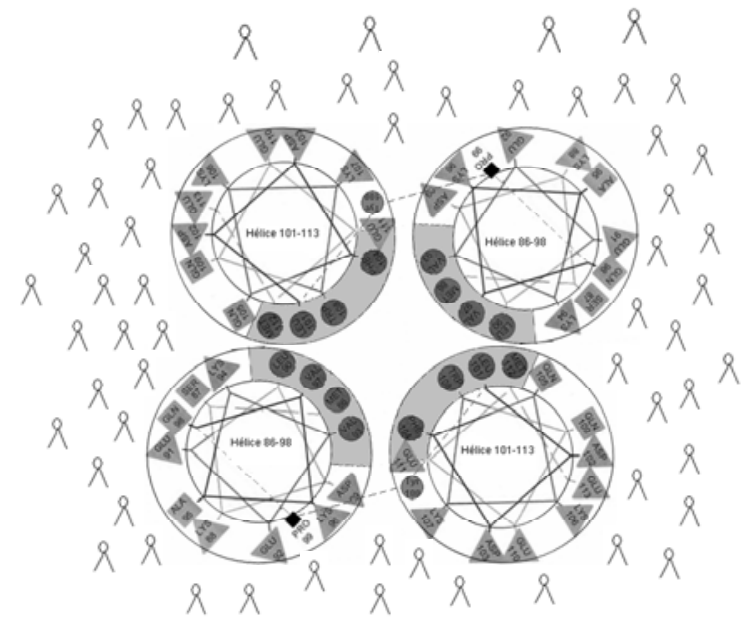

Fig. V-3a: diagrama de Edmudson que muestra la interacción de la región central formando dímeros en solución

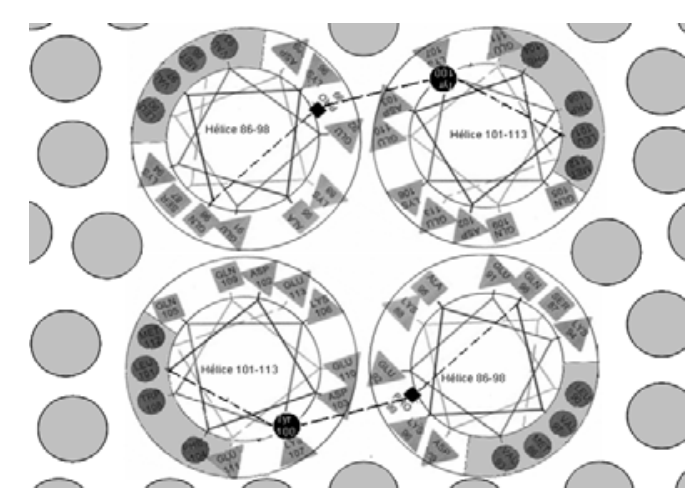

Fig. V-3b: diagrama de Edmudson que muestra la interacción de la región central formando en su inserción en membranas

Una observación realizada en este trabajo para la que no tenemos una explicación muy simple es la ausencia de influencia tanto de apoA-I como de AI 77-120 sobre la movilidad y ordenamiento de marcadores lipídicos en vesículas, ya que sería de esperar que el modo de inserción planteado afecte sensiblemente a la dinámica y ordenamiento de los lípidos circundantes. Ni diferentes marcadores de EPR localizados a diferente profundidad en la membrana ni la sonda Laurdan fueron capaces de detectar 
algún cambio en la dinámica y ordenamiento de los lípidos. Recientemente, Sanchez y col (Sanchez et al., 2007) también reportaron la ausencia de efecto de apoA-I sobre la polarización generalizada de Laurdan en vesículas gigantes de POPC. En el caso de apoA-I, como la región central sería la única que se inserta verticalmente, su influencia podría estar "diluida" y probablemente también compensada por un efecto opuesto de el resto de las hélices que se empotrarían verticalmente. Para AI 77-120, sin embargo, esta "compensación" sería más improbable aunque su baja afinidad por la membrana podría resultar en la ausencia de efecto.
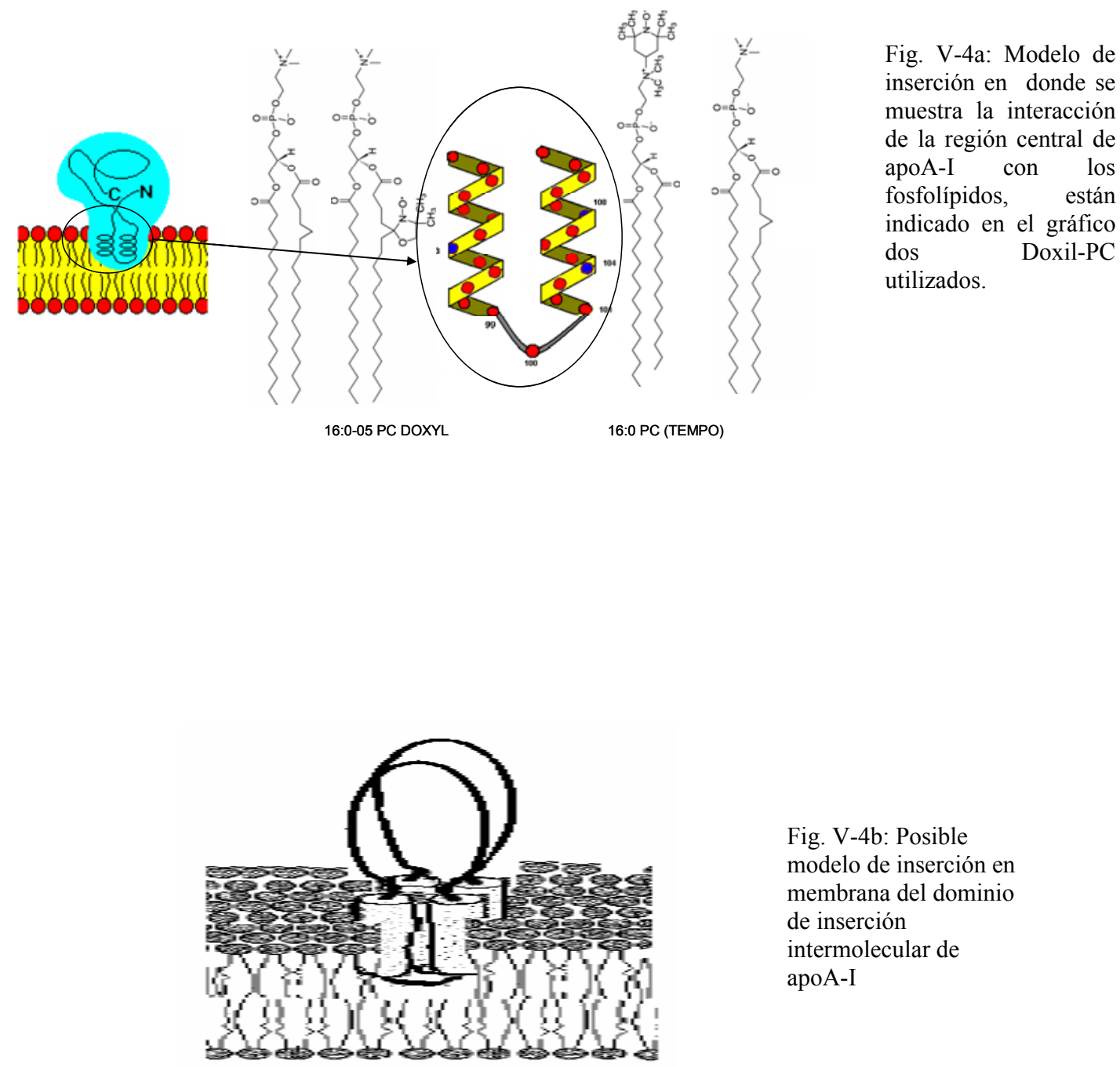

Fig. V-4b: Posible modelo de inserción en membrana del dominio de inserción intermolecular de apoA-I 
b) Análisis funcional de la región central:

Los estudios realizados con el péptido AI 77-120, reproducen muchas de las características de la apoA-I, e indican así que las hélices $\mathrm{Y}$ centrales tienen una cierta independencia funcional del resto de la molécula de apoA-I. Como apoA-I, el péptido A-I 77-120 se une a vesículas y es accesible al reactivo fotoactivable ${ }^{125}$ I-TID/PC.

Similarmente a lo que ocurre con apoA-I (Yokoyama et al., 1980), AI 77-120 tiene selectividad para unirse a membranas con colesterol. La afinidad de AI 77-120 por membranas, sin embargo, es bastante menor que para apoA-I, aunque es del mismo orden que la reportada para HDL discoidales. Esto indica que el par de hélices Y central no es el único que participa en la unión de apoA-I a vesículas, pero sugiere que probablemente sea la única región involucrada en la unión de HDL discoidales a membranas.

Las bases moleculares para la selectividad por colesterol pueden deberse a ciertas secuencias de reconocimiento que existen en las secuencias de apoA-I o de AI 77-120. Li y col (Li and Papadopoulos, 1998) postularon la existencia de ciertas secuencias consenso que existen en proteínas que unen colesterol (CRACS). La secuencia consenso propuesta es: $-\mathrm{L} / \mathrm{V}-(\mathrm{X})_{1-5}-\mathrm{Y}-(\mathrm{X})_{1-5}-\mathrm{R} / \mathrm{K}-$, donde $-(\mathrm{X})_{-1-5}$ representa de uno a cinco residuos de cualquier aminoácido. Se ha demostrado también que un análogo fotoactivable se une directamente a una de esas secuencias en el receptor de Benzodiazepina (Li et al., 2001) y que el péptido LWYIK no sólo tiene selectividad por membranas ricas en colesterol, sino también es capaz de inducir la reorganización de bicapas de PC/Col para producir dominios ricos en este compuesto (Epand et al., 2003). El residuo de Tirosina (Y) en el centro de estos motivos sería esencial para establecer, presumiblemente, contacto de puentes de hidrógeno con el - $\mathrm{OH}$ del colesterol. Cinco de estas secuencias consenso existen en la secuencia de la apoA-I, estando una de ella presentes entre los residuos 97-106 (-VQPYLDDFQK-) y por lo tanto podría ser el responsable de conferirle la selectividad por membranas al péptido AI 77-120, las otras cuatro secuencias (14-LATVYVDVLK-. 163- LAPYSDELR-, 189-LAEYHAK-, 233LEEYTKK) podrían contribuir a la selectividad por membrana de la apoA-I.

AI 77-120 también presenta similar actividad que la apoA-I para promover la desorción de colesterol y facilitar su transporte a vesículas aceptoras, como se determinó utilizando un análogo fluorescente de colesterol o colesterol radiactivo (Toledo et al., 2004). Esto muy probablemente esté relacionado con el hecho de que el 
colesterol parece ser excluído del entorno de las hélices 3-4 cuando estas se encuentran insertadas en la membrana, como lo indicaron los estudios de quenching con el análogo 3- $\beta$-doxil-colestano. También en HDL discoidales reconstituídas con apoA-I se ha reportado que el colesterol es excluído de la proximidad de la proteína en el borde del disco (Massey et al., 1985). No es muy simple de compatibilizar el hecho de que apoA-I y AI 77-120 presenten una preferencia por membranas ricas en colesterol y al mismo tiempo tengan la capacidad de catalizar su desorción. Si la selectividad por membranas ricas en colesterol se debe como fue propuesto por Li y colaboradores a las secuencias de reconocimiento de colesterol, estas deberían ser activas al momento de unirse la proteína a la membrana, pero en el estado unido, algún cambio conformacional debería inactivarla de manera que se pierda la afinidad por colesterol y se facilite su exclusión del entorno y su desorción de la membrana.

Recientemente, nuestro grupo también ha obtenido evidencias de que las hélices Y centrales de apoA-I juegan un rol importante en la interacción con la membrana celular y en desencadenar la movilización de depósitos intracelulares de colesterol hacia la membrana plasmática (Gonzalez et al., 2008).

\section{Partículas discoidales de HDL}

Dado que las HDL discoidales son eficientes aceptores de colesterol, y que son los primeros productos de lipidación, se estudió en este trabajo la estructura adquirida por la apo A-I en partículas discoidales. Hay gran consenso que la conformación de la apoA-I en complejos lipídicos es significativamente diferente a la que posee en el estado libre en solución, y que la proteína en este caso expone la cara hidrofóbica de al menos la mayoría de las hélices anfipáticas hacia las cadenas acílicas de los fosfolípidos. Esto se esquematiza en la figura I-17 de Introducción). Sin embargo, ha sido propuesto que algunas hélices de apo A-I podrían presentar configuraciones alternativas (unidas o despegadas del borde del disco), de manera de que un disco con el mismo número de moléculas pueda acomodar diferente cantidad de lípidos. Esto explicaría porqué el tamaño de los discos cambia de manera discreta. En particular para las repeticiones helicoidales tipo $\mathrm{Y}$, experimentos previos de nuestro laboratorio con reactivos fotoactivables (Corsico et al., 2001) indicaron que ambos pares de hélices Y (el 3-4 y el 9-10) tienen un menor contacto con los lípidos del disco en comparación con el resto de las hélices. El hecho de que el par 3-4 pueda hallarse relativamente 
"despegado" del borde del disco puede tener una gran implicancia para la formación del ramillete intermolecular de estas hélices que constituiría el postulado dominio de inserción en membranas.

Para que este ramillete intermolecular pueda ser formado en las HDL discoidales, se requiere que ambos pares de hélices 3-4 se encuentren cercanos entre sí. Esto sería posible en algunas configuraciones propuestas que se mencionaron en la Introducción, como la hebilla cabeza-cabeza de Tricerri y col (Tricerri et al., 2001) y el doble cinturón 2/5 de Silva y col (Silva et al., 2005b). Ambos trabajos fueron realizados en HDL discoidales reconstituídas con colato. En ambos casos, los datos no pudieron ser compatibilizados con una única configuración, por lo que se asumió la coexistencia de dos configuraciones. Tricerri y col. propusieron que la hebilla cabeza-cabeza coexiste con la hebilla cabeza-cola, mientras que Silva propone que el cinturón 2/5 coexiste con el $5 / 5$.

Como mencionamos anteriormente, la unión de apoA-I (y de AI 77-120) a la membrana va acompañada de oligomerización y la región central parece jugar un rol en el proceso como se postuló para la formación del dominio de inserción intermolecular. Como la unión de apoA-I a la membrana es la etapa previa para la posterior formación de HDL discoidales en el proceso de micelización, una vez formado el dominio intermolecular de las hélices 3-4 que queda insertado en la membrana, esto podría restringir la configuración final en los discos. Esta posibilidad fue ensayada por medio de la reconstitución de HDL discoidales de DMPC por ambos métodos (con colato o micelización directa a la temperatura de transición). El análisis de los productos de crosslinking de lisinas y tripsinólisis indicó un perfil diferente (tanto por HPLC como por MALDI-TOF) para los discos formados por uno u otro método. Aunque muchos picos son comunes a ambos tipos de discos, algunos sólo están presentes en los espectros (o cromatogramas) correspondientes a los discos preparados con colato y ausentes en los preparados por micelización directa, sugiriendo que en estos últimos existiría sólo una de las configuraciones. La preparación de discos con las mutantes W@104 y W@108, y la detección en los mismos de homotransferencia de energía indicó que ésta ocurre en ambos tipos de discos, pero con una eficiencia bastante mayor en el caso de los discos generados por micelización directa, indicando que éstos tendrían preferiblemente (o exclusivamente) la configuración con las hélices 4 en estrecho contacto entre sí (esto es la hebilla cabeza-cabeza o el doble cinturón 2/5) 
Si bien no hay datos sobre la configuración de apoA-I en discos naturales o generados por células, es razonable suponer que la misma restricción impuesta por la inserción del ramillete intermolecular de los pares de hélices 3-4 para la configuración de apo A-I en los discos generados por micelización pueda ocurrir para la generación de HDL discoidales por la interacción de apoA-I con la membrana celulares. Así, es muy probable que las HDL naturales también posean esta configuración única que permite la formación del dominio de inserción activo en los discos HDL.

La figura V-5 muestra que el ramillete intermolecular de las hélices Y centrales podría formarse tanto en la configuración de hebilla cabeza-cabeza como en el doble cinturón $2 / 5$. Esto permitiría su inserción en membranas y explicaría varios hechos ya observados en la interacción de HDL discoidales con membranas como: 1) que esta región se encuentre relativamente "despegada" del borde del disco, pero que sea la única accesible al reactivo ${ }^{125}$ I-TID/PC incorporado en vesículas (Corsico et al., 2001), 2) la similar afinidad por membranas que presentan las HDL discoidales y el péptido AI 77120, y 3) la preferencia (o mayor afinidad) de las HDL discoidales por membranas ricas en colesterol y su desorción de las mismas, así como la inducción de pérdida de contenido acuoso de vesículas por las partículas discoidales (Tricerri et al., 1998), (Toledo et al., 2000)

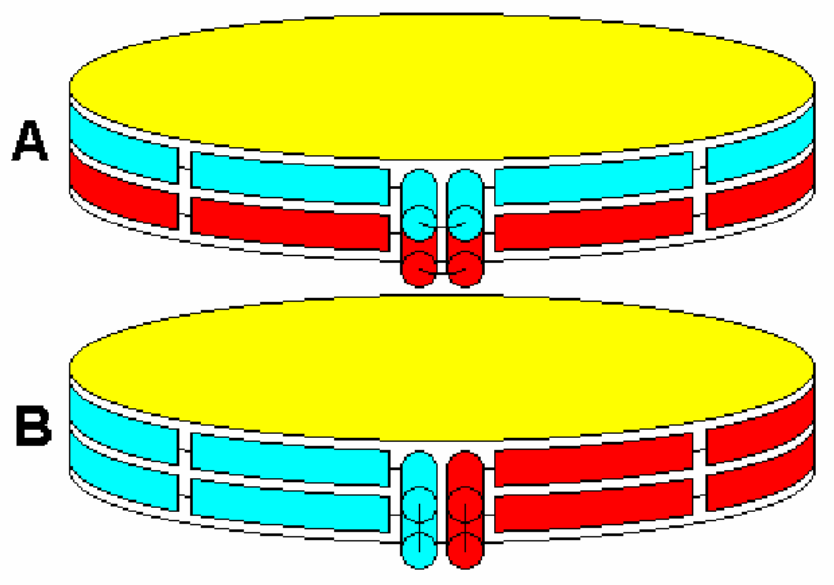

Figura V-5. Posibles modos de formación del ramillete intermolecular de las hélices $\mathrm{Y}$ centrales de apoA-I en HDL discoidales con 2 moléculas de apo A-I. A) de acuerdo con la configuración del doble cinturón $2 / 5, y$ B) de acuerdo con la conficuración de la hebilla cabeza-cabeza

Por otro lado, también se estudió en este trabajo la movilidad y ordenamiento de la fase lipídica de las HDL reconstituídas con DMPC en comparación con vesículas multilamelares de este fosfolípido, usando EPR con marcadores lipídicos a diferentes profundidades de la bicapa lipídica. Se observó un efecto de la apoA-I bastante similar 
al producido por sustancias que se intercalan en la bicapa lipídica como el colesterol, disminuyendo el ordenamiento de las cadenas hidrocarbonadas en el estado gel, e incrementándolo en el estado fluido. Jonas y colaboradores (Jonas et al., 1987) también observaron que apoA-I en las HDL discoidales produce un aumento en el grado de empaquetamiento en el estado fluido midiendo polarización de fluorescencia con difenilhexatrieno (DPH), y el corrimiento de la emisión de la sonda PRODAN.

De acuerdo con los modelos de los complejos discoidales, la apoA-I se dispone en el borde del disco con las hélices anfipáticas "protegiendo" a las cadenas hidrocarbonadas de su exposición al medio acuoso, por lo que es razonable asumir una intercalación de la misma entre las cadenas hidrocarbonadas de los fosfolípidos. Aún con la proteína en el borde del disco, un gran porcentaje de los lípidos sería directamente afectado, por lo que el efecto resultante sería similar al producido por la intercalación. Estos discos contienen alrededor de 120 moléculas de DMPC (60 en cada monocapa) y dos moléculas de apoA-I. Asumiendo un empaquetamiento hexagonal, unas 24 moléculas de DMPC (40\%) se localizarán en el borde de cada hemicapa interactuando directamente con las caras hidrofóbicas de las hélices de apoA-I. Los grupos hidrofóbicos de los aminoácidos de la cara no polar de las hélices quedarían intercalados entre las cadenas hidrocarbonadas de los fosfolípidos localizados en el borde restringiendo su movilidad en el estado fluido e impidiendo su empaquetamiento ordenado en la fase gel. Si la influencia de la proteína se extendiera al segundo anillo de lípidos más cercanos, el porcentaje de lípidos afectados alcanzaría al 70\%.

Esta interacción de las caras hidrofóbicas de las hélices con las cadenas hidrocarbonadas de los fosfolípidos del borde del disco debería ser muy ajustada para evitar la entrada de agua o la exposición al agua de restos hidrofóbicos. El resultado de la misma es que en el estado fluido, el cinturón de hélices de apoA-I "aprieta" a la región de las cadenas hidrocarbonadas restringiendo su movilidad, dejando relativamente "suelta" a la región de los grupos polares. Por debajo de $24{ }^{\circ} \mathrm{C}$, el cinturón de apoA-I actuaría de modo inverso, impidiendo el estrecho empaquetamiento de las cadenas hidrocarbonadas pero sin afectar mayormente al ordenamiento en la región de los grupos polares. Esto podría deberse a que la intercalación de los restos de aminoácidos hidrofóbicos entre las cadenas hidrocarbonadas de los lípidos del borde dificulta su empaquetamiento. Además, si el cinturón proteico es relativamente rígido también podría dificultar la contracción y compactación de los lípidos en la fase gel. En ausencia de alguna restricción impuesta por la proteína, la superficie del disco lipídico 
se reduciría de unos 54 a unos $30 \mathrm{~nm}^{2}$ al pasar del estado fluido al estado gel (se asume 0,7 y $0,5 \mathrm{~nm}^{2} /$ molécula en estado fluido y gel respectivamente). Puede estimarse que el diámetro del disco lipídico se reduciría cerca del 20\% en ese proceso. En presencia de un cinturón de hélices rígido, el disco lipídico no podría contraerse libremente ya que su separación del cinturón es energéticamente desfavorable y dejaría un espacio libre para la entrada de agua, por lo que los lípidos no podrían adquirir el estado altamente compactado y ordenado de la fase gel que presentan en las vesículas de DMPC pura. Así, la influencia de un cinturón proteico rígido sobre las propiedades de los lípidos del disco puede ser muy similar a la producida por compuestos que se intercalan en la bicapa lipídica como el colesterol.

Es de notar que la transición de fase de la DMPC en los discos es menos abrupta que en vesículas multilamelares, pero no desaparece completamente como ocurre en vesículas con muy alto contenido de colesterol. En realidad, los cambios en los parámetros de orden en relación a las vesículas de DMPC pura no son tan grandes como podría esperarse de las consideraciones anteriores ya que no superan el $20 \%$, por lo que aún debería ocurrir un cambio importante en el área ocupada por la DMPC en los discos durante la transición. Por la gran flexibilidad conformacional que presentan las apolipoproteínas intercambiables como apoA-I, es razonable suponer que el "cinturón" de hélices en el borde del disco no sea totalmente rígido y que pueda adaptarse al menos parcialmente al cambio de la superficie de la bicapa lipídica. Aunque no hay datos al respecto, se podría especular sobre dos posibles modos de adaptación: a) La reducción de superficie ocupada por los lípidos podría ocurrir sin cambios en el perímetro si un disco circular se transforma en uno de forma oval, y b) De mantenerse la forma circular, el cinturón proteico podría adaptarse a los cambios de perímetro cambiando el número de hélices en contacto con el borde del disco como ha sido propuesto para HDL discoidales con diferente cantidad de lípidos. 


\section{Conclusión General}

Los datos obtenidos en este trabajo soportan la hipótesis central planteada originalmente de que el par de hélices Y central (3-4) de apoA-I constituye un dominio con independencia estructural y funcional del resto de la molécula de apoA-I, y nos permiten concluir y postular que:

- Este dominio participa en la unión de apoA-I (y de HDL discoidales) a membranas teniendo preferencia o mayor afinidad por membranas ricas en colesterol.

- La unión de este par de hélices a la membrana se produce por la inserción con el eje mayor de las hélices perpendicular a la superficie de la membrana y ocurriría sin grandes cambios en la estructura secundaria.

- Esta inserción no genera cambios apreciables en la dinámica y ordenamiento de los lípidos de la membrana, pero resultaría en la exclusión del colesterol del entorno del dominio, en la facilitación de la desorción del colesterol de la membrana y en consecuencia la transferencia a otros aceptores.

- El dominio de inserción "activo" sería un ramillete intermolecular formado por los dos pares de hélices 3-4 de un dímero de apoA-I, interactuando entre sí por las caras hidrofílicas de las hélices.

- En los dímeros de apoA-I en solución acuosa, este ramillete tendría la configuración inversa, es decir con las hélices interactuando entre sí mediante las caras hidrofóbicas.

- En las HDL discoidales, la interacción de las hélices de apoA-I con el borde del disco lipídico afecta a la dinámica y ordenamiento de los lípidos de manera diferencial, dependiendo de la profundidad en la bicapa lipídica, así como también del estado de fase de los lípidos.

- En las HDL discoidales de 2 moléculas de apoA-I reconstituídas con detergentes coexistirían al menos dos configuraciones de la apoA-I: Una de ellas con los 2 pares de hélices 3-4 en estrecho contacto entre sí, lo que permitiría la formación del ramillete intermolecular.

- Las HDL formadas por la reacción directa con vesículas fosfolipídicas en la transición de fase presentarían exclusivamente la configuración anterior que permitiría que se forme el ramillete intermolecular de las hélices 3-4 y consecuentemente el dominio de inserción activo. 
Los datos obtenidos en estos estudios pueden tener una gran implicancia biológica y fisiológica ya que apoyan la idea de que la interacción de apoA-I con distintos entornos celulares pueda promover conformaciones específicas que regulen la exportación de lípidos y su función como factor protector antiaterosclerótico. En especial la postulación del ramillete intermolecular de las hélices Y centrales permite especular sobre que la afinidad de las HDL por la membrana pueda ser regulada por variables como el tamaño o el contenido de colesterol de los discos a través de la modulación de la formación del dominio de inserción "activo". 


\section{REFERENCIAS}

Ajees, A.A., Anantharamaiah, G.M., Mishra, V.K., Hussain, M.M., Murthy, H.M., 2006, Crystal structure of human apolipoprotein A-I: insights into its protective effect against cardiovascular diseases, Proc Natl Acad Sci U S A, 103, 2126-31.

Anderson, D.W., Nichols, A.V., Forte, T.M., Lindgren, F.T., 1977, Particle distribution of human serum high density lipoproteins, Biochim Biophys Acta, 493, 55-68.

Arnulphi, C., Jin, L., Tricerri, M.A., Jonas, A., 2004, Enthalpy-driven apolipoprotein AI and lipid bilayer interaction indicating protein penetration upon lipid binding, Biochemistry, 43, 12258-64.

Assmann, G., von Eckardstein, A., Funke, H., 1993, High density lipoproteins, reverse 12 transport of cholesterol, and coronary artery disease. Insights from mutations, Circulation, 87, III 28-34.

Badimon, J.J., Badimon, L., Galvez, A., Dische, R., Fuster, V., 1989, High density lipoprotein plasma fractions inhibit aortic fatty streaks in cholesterol-fed rabbits, Lab Invest, 60, 455-61.

Barrans, A., Jaspard, B., Barbaras, R., Chap, H., Perret, B., Collet, X., 1996, Pre-beta HDL: structure and metabolism, Biochim Biophys Acta, 1300, 73-85.

Behling Agree, A.K., Tricerri, M.A., Arnvig McGuire, K., Tian, S.M., Jonas, A., 2002, Folding and stability of the C-terminal half of apolipoprotein A-I examined with a Cys-specific fluorescence probe, Biochim Biophys Acta, 1594, 286-96.

Bergeron, J., Frank, P.G., Scales, D., Meng, Q.H., Castro, G., Marcel, Y.L., 1995, Apolipoprotein A-I conformation in reconstituted discoidal lipoproteins varying in phospholipid and cholesterol content, J Biol Chem, 270, 27429-38.

Berliner, L.J. 2002.. Spin Labeling -The next milenium. In Biological Magnetic Resonance. Kluwer Acad. Publisher.

Borhani, D.W., Rogers, D.P., Engler, J.A., Brouillette, C.G., 1997, Crystal structure of truncated human apolipoprotein A-I suggests a lipid-bound conformation, Proc Natl Acad Sci U S A, 94, 12291-6.

Brown, M.S., Goldstein, J.L., 1983, Lipoprotein metabolism in the macrophage: implications for cholesterol deposition in atherosclerosis, Annu Rev Biochem, $52,223-61$.

Brown, M.S., Goldstein, J.L., 1986, A receptor-mediated pathway for cholesterol homeostasis, Science, 232, 34-47. 
Castro, G.R., Fielding, C.J., 1988, Early incorporation of cell-derived cholesterol into pre-beta-migrating high-density lipoprotein, Biochemistry, 27, 25-9.

Chattopadhyay, A., London, E., 1987, Parallax Method for Direct Measurement of Membrane Penetration Depth Utilizing Fluorescence Quenching by SpinLabeled Phospholipids, Biochemistry 26, 39-45.

Cho, K.H., Jonas, A., 2000, A key point mutation (V156E) affects the structure and functions of human apolipoprotein A-I, J Biol Chem, 275, 26821-7.

Corsico, B., Toledo, J.D., Garda, H.A., 2001, Evidence for a central apolipoprotein A-I domain loosely bound to lipids in discoidal lipoproteins that is capable of penetrating the bilayer of phospholipid vesicles, J Biol Chem, 276, 16978-85.

Cullis, P., Hope, M.J., 1991, Lipoproteins and Membrane, Biochemistry and Lipids, D.E. Vance and J.Vance, editors. Elsevier Press, Amsterdam.

Davidson, W.S., Arnvig-McGuire, K., Kennedy, A., Kosman, J., Hazlett, T.L., Jonas, A., 1999, Structural organization of the N-terminal domain of apolipoprotein AI: studies of tryptophan mutants, Biochemistry, 38, 14387-95.

Davidson, W.S., Hilliard, G.M., 2003, The spatial organization of apolipoprotein A-I on the edge of discoidal high density lipoprotein particles: a mass specrometry study, J Biol Chem, 278, 27199-207.

Davidson, W.S., Silva, R.A., 2005, Apolipoprotein structural organization in high density lipoproteins: belts, bundles, hinges and hairpins, Curr Opin Lipidol, 16, 295-300.

de Beer, M.C., Durbin, D.M., Cai, L., Jonas, A., de Beer, F.C., van der Westhuyzen, D.R., 2001a, Apolipoprotein A-I conformation markedly influences HDL interaction with scavenger receptor BI, J Lipid Res, 42, 309-13.

de Beer, M.C., Durbin, D.M., Cai, L., Mirocha, N., Jonas, A., Webb, N.R., de Beer, F.C., van Der Westhuyzen, D.R., 2001b, Apolipoprotein A-II modulates the binding and selective lipid uptake of reconstituted high density lipoprotein by scavenger receptor BI, J Biol Chem, 276, 15832-9.

Epand, R.M., Sayer, B.G., Epand, R.F., 2003, Peptide-induced formation of cholesterolrich domains, Biochemistry, 42, 14677-89.

Fielding, C.J., Fielding, P.E., 1981, Evidence for a lipoprotein carrier in human plasma catalyzing sterol efflux from cultured fibroblasts and its relationship to lecithin:cholesterol acyltransferase, Proc Natl Acad Sci U S A, 78, 3911-4. 
Fielding, C.J., Fielding, P.E., 2001, Cellular cholesterol efflux, Biochim Biophys Acta, $1533,175-89$.

Fielding, P.E., Fielding, C.J., 1995, Plasma membrane caveolae mediate the efflux of cellular free cholesterol, Biochemistry, 34, 14288-92.

Fielding, P.E., Nagao, K., Hakamata, H., Chimini, G., Fielding, C.J., 2000, A two-step mechanism for free cholesterol and phospholipid efflux from human vascular cells to apolipoprotein A-1, Biochemistry, 39, 14113-20.

Fredrickson, D.S., 1964, The Inheritance of High Density Lipoprotein Deficiency (Tangier Disease), J Clin Invest, 43, 228-36.

Garda, H.A., Arrese, E.L., Soulages, J.L., 2002, Structure of apolipophorin-III in discoidal lipoproteins. Interhelical distances in the lipid-bound state and conformational change upon binding to lipid, J Biol Chem, 277, 19773-82.

Gill, S.C., von Hippel, P.H., 1989, Calculation of protein extinction coefficients from amino acid sequence data. , Anal. Biochem., 182, 319-326.

Goldman, S.A., Bruno, G.V., Polnaszke, C.F., Freed, J.H., 1972, Local dynamics of polymers in solution by spin label ESR. J.Phys.Chem., 56, 716-735.

Gonzalez, M.C., Toledo, J.D., Tricerri, M.A., Garda, H.A., 2008, The central type Y amphipathic alpha-helices of apolipoprotein AI are involved in the mobilization of intracellular cholesterol depots, Arch Biochem Biophys, 473, 34-41.

Gordon, D.J., 1990, Role of circulating High Density Lipoprotein and Triglicerides in coronary artery disease: risk and prevention. Endocrinol Metab. Clin. North. Am..19, 299.

Gursky, O., Atkinson, D., 1996, Thermal unfolding of human high-density apolipoprotein A-1: implications for a lipid-free molten globular state, Proc Natl Acad Sci U S A, 93, 2991-5.

Hamman, B.D., Oleinikov, A.V., Jokhadze, G.G., Traut, R.R., Jameson, D.M., 1996, Dimer/monomer equilibrium and domain separations of Escherichia coli ribosomal protein L7/L12, Biochemistry, 35, 16680-6.

Hwang, J.S., Mason, R.P., Hwang, L.P., Freed, J.H., 1975, Electron spin Resonance studies of anisotropic rotational reorientation and slow tumbling in liquid and frozen media III. Perdeuterated 2,2,6,6, tetramethul-4-piperidone N-oxide and an analysis of fluctuating torques. J.Phys. Chem, 79, 489.

Ingram, D.J.E., 1969, Biological and Bichemestry application of electron spin resonance. London Publisher, Adam Hilger Ltd 
Ji, Y., Jonas, A., 1995, Properties of an N-terminal proteolytic fragment of apolipoprotein $\mathrm{AI}$ in solution and in reconstituted high density lipoproteins, $\mathrm{J}$ Biol Chem, 270, 11290-7.

Jonas, A., 2000, Lecithin cholesterol acyltransferase, Biochim Biophys Acta, 1529, 24556.

Jonas, A., Kezdy, K.E., Wald, J.H., 1989, Defined apolipoprotein A-I conformations in reconstituted high density lipoprotein discs, J Biol Chem, 264, 4818-24.

Jonas, A., Wald, J.H., Toohill, K.L., Krul, E.S., Kezdy, K.E., 1990, Apolipoprotein A-I structure and lipid properties in homogeneous, reconstituted spherical and discoidal high density lipoproteins, J Biol Chem, 265, 22123-9.

Jonas, A., Zorich, N.L., Kezdy, K.E., Trick, W.E., 1987, Reaction of discoidal complexes of apolipoprotein A-I and various phosphatidylcholines with lecithin cholesterol acyltransferase. Interfacial effects, J Biol Chem, 262, 3969-74.

Joyce, C., Freeman, L., Brewer, H.B., Jr., Santamarina-Fojo, S., 2003, Study of ABCA1 function in transgenic mice, Arterioscler Thromb Vasc Biol, 23, 965-71.

Kelley, L.A., MacCallum, R.M., Sternberg, M.J., 2000, Enhanced genome annotation using structural profiles in the program 3D-PSSM, J Mol Biol, 299, 499-520.

Krimbou, L., Hajj Hassan, H., Blain, S., Rashid, S., Denis, M., Marcil, M., Genest, J., 2005, Biogenesis and speciation of nascent apoA-I-containing particles in various cell lines, J Lipid Res, 46, 1668-77.

Kunitake, S.T., Chen, G.C., Kung, S.F., Schilling, J.W., Hardman, D.A., Kane, J.P., 1990, Pre-beta high density lipoprotein. Unique disposition of apolipoprotein AI increases susceptibility to proteolysis, Arteriosclerosis, 10, 25-30.

Laemmli, U.K., 1970, Cleavage of structural proteins during the assembly of the head of bacteriophage T4., Nature(London), 227, 680.

Lakowicz, J.R., 1999, Principles of Fluorecence Spectroscopy, Plenum Press. Segunda Edición, 1-698.

Lederberg, E.M., Cohen, S.N., 1974, Transformation of Salmonella typhimurium by Plasmad Deoxyribonucleic Acid, J. Bacteriol, 119, 1072-4.

Leroy, A., Toohill, K.L., Fruchart, J.C., Jonas, A., 1993, Structural properties of high density lipoprotein subclasses homogeneous in protein composition and size, $\mathrm{J}$ Biol Chem, 268, 4798-805.

Letizia, J.Y., Phillips, M.C., 1991, Effects of apolipoproteins on the kinetics of cholesterol exchange, Biochemistry, 30, 866-73. 
Lewis, G.F., Rader, D.J., 2005, New insights into the regulation of HDL metabolism and reverse cholesterol transport, Circ Res, 96, 1221-32.

Li, H., Lyles, D.S., Thomas, M.J., Pan, W., Sorci-Thomas, M.G., 2000, Structural determination of lipid-bound ApoA-I using fluorescence resonance energy transfer, J Biol Chem, 275, 37048-54.

Li, H., Papadopoulos, V., 1998, Peripheral-type benzodiazepine receptor function in cholesterol transport. Identification of a putative cholesterol recognition/interaction amino acid sequence and consensus pattern, Endocrinology, 139, 4991-7.

Li, H., Yao, Z., Degenhardt, B., Teper, G., Papadopoulos, V., 2001, Cholesterol binding at the cholesterol recognition/ interaction amino acid consensus (CRAC) of the peripheral-type benzodiazepine receptor and inhibition of steroidogenesis by an HIV TAT-CRAC peptide, Proc Natl Acad Sci U S A, 98, 1267-72.

Li, L., Chen, J., Mishra, V.K., Kurtz, J.A., Cao, D., Klon, A.E., Harvey, S.C., Anantharamaiah, G.M., Segrest, J.P., 2004, Double belt structure of discoidal high density lipoproteins: molecular basis for size heterogeneity, J Mol Biol, 343, 1293-311.

Lodish, H., Berk, A. Matsudaira, P.,Kaiser, Krieger, Scott, Zipursky, S. L., Darnell, J.. 2005. Molecular Cell Biology. W. H. Freeman Ed

Luna-Chavez, C., Gong, E., Forte, T., AV, N., 1994, Sodium oleate-facilitated reassembly of apolipoprotein A-I with phosphatidylcholine, Biochim Biophys Acta., 1215, 141-9.

Lund-Katz, S., Hammerschlag, B., Phillips, M.C., 1982, Kinetics and mechanism of free cholesterol exchange between human serum high- and low-density lipoproteins, Biochemistry, 21, 2964-9.

Maiorano, J.N., Davidson, W.S., 2000, The orientation of helix 4 in apolipoprotein A-Icontaining reconstituted high density lipoproteins, J Biol Chem, 275, 17374-80.

Marcel, Y.L., Kiss, R.S., 2003, Structure-function relationships of apolipoprotein A-I: a flexible protein with dynamic lipid associations, Curr Opin Lipidol, 14, 151-7.

Marcel, Y.L., Provost, P.R., Koa, H., Raffai, E., Dac, N.V., Fruchart, J.C., Rassart, E., 1991, The epitopes of apolipoprotein A-I define distinct structural domains including a mobile middle region, J Biol Chem, 266, 3644-53. 
Martinez, L.O., S. Jacquet, F.T., Collet, X., Perret, B., Barbaras*, R., 2004, New insight on the molecular mechanisms of high-density lipoprotein cellular interactions, CMLS Cellular and Molecular Life Sciences, 61, 2343-2360.

Massey, J.B., She, H.S., Gotto, A.M., Jr., Pownall, H.J., 1985, Lateral distribution of phospholipid and cholesterol in apolipoprotein A-I recombinants, Biochemistry, 24, 7110-6.

Matz, C.E., Jonas, A., 1982a, Micellar complexes of human apolipoprotein A-I with phosphatidylcholines and cholesterol prepared from cholate-lipid dispersions, $\mathrm{J}$ Biol Chem, 257, 4535-40.

Matz, C.E., Jonas, A., 1982b, Reaction of human lecithin cholesterol acyltransferase with synthetic micellar complexes of apolipoprotein A-I, phosphatidylcholine, and cholesterol, J Biol Chem, 257, 4541-6.

McGuire, K.A., Davidson, W.S., Jonas, A., 1996, High yield overexpression and characterization of human recombinant proapolipoprotein A-I, J Lipid Res, 37, 1519-28.

McMillan, J.A. 1975. Paramagnetismo electronico. Washington: The General Secretariat of the Organization of Amer, editor. $115 \mathrm{p}$.

Moens, P.D., Helms, M.K., Jameson, D.M., 2004, Detection of tryptophan to tryptophan energy transfer in proteins, Protein J, 23, 79-83.

Morse II, P.D., 1986, Determining intracellular viscosity from the rotational motion of spin labels Methods in Enzymology,, 127, 239-249.

Nolde, D.E., Sobol, A.G., Pluzhnikov, K.A., Grishin, E.V., Arseniev, A.S., 1995, Three-dimensional structure of ectatomin from Ectatomma tuberculatum ant venom, J Biomol NMR, 5, 1-13.

O'Connell, B.J., Genest, J., Jr., 2001, High-density lipoproteins and endothelial function, Circulation, 104, 1978-83.

Oram, J.F., 2000, Tangier disease and ABCA1, Biochim Biophys Acta, 1529, 321-30.

Oram, J.F., 2002, ATP-binding cassette transporter A1 and cholesterol trafficking, Curr Opin Lipidol, 13, 373-81.

Oram, J.F., Lawn, R.M., 2001, ABCA1. The gatekeeper for eliminating excess tissue cholesterol, J Lipid Res, 42, 1173-9.

Palgunachari, M.N., Mishra, V.K., Lund-Katz, S., Phillips, M.C., Adeyeye, S.O., Alluri, S., Anantharamaiah, G.M., Segrest, J.P., 1996, Only the two end helixes of eight tandem amphipathic helical domains of human apo A-I have significant lipid 
affinity. Implications for HDL assembly, Arterioscler Thromb Vasc Biol, 16, 328-38.

Phillips, J.C., Wriggers, W., Li, Z., Jonas, A., Schulten, K., 1997, Predicting the structure of apolipoprotein A-I in reconstituted high-density lipoprotein disks, Biophys J, 73, 2337-46.

Pluzhnikov, K., Nosyreva, E., Shevchenko, L., Kokoz, Y., Schmalz, D., Hucho, F., Grishin, E., 1999, Analysis of ectatomin action on cell membranes, Eur J Biochem, 262, 501-6.

Remaley, A.T., Hoeg, J.M., 1995, Polarized secretion of apoA-I and apoA-II by transfected MDCK cells, J Lipid Res, 36, 407-13.

Rogers, D.P., Roberts, L.M., Lebowitz, J., Engler, J.A., Brouillette, C.G., 1998, Structural analysis of apolipoprotein A-I: effects of amino- and carboxy-terminal deletions on the lipid-free structure, Biochemistry, 37, 945-55.

Rothblat, G.H., Mahlberg, F.H., Johnson, W.J., Phillips, M.C., 1992, Apolipoproteins, membrane cholesterol domains, and the regulation of cholesterol efflux, J Lipid Res, 33, 1091-7.

Sanchez, S.A., Tricerri, M.A., Gratton, E., 2007, Interaction of high density lipoprotein particles with membranes containing cholesterol, J Lipid Res, 48, 1689-700.

Scanu, A.M., Tardieu, A., 1971, Temperature transitions of lipid mixtures containing cholesterol esters. Relevance to the structural problem of serum high density lipoprotein, Biochim Biophys Acta, 231, 170-4.

Schägger, H., Jagow, G.v., 1987, Tricine-sodium dodecyl sulfate-polyacrylamide gel electrophoresis for the separation of proteins in the range from 1 to $100 \mathrm{kDa}$, Anal Biochem, 166, 368-79.

Seelig, J., 1970, A spin label study of oriented liquid crystal (a model system for bilayer membranes) J. Am. Chem. Soc., 92, 3881.

Segrest, J.P., Jones, M.K., De Loof, H., Brouillette, C.G., Venkatachalapathi, Y.V., Anantharamaiah, G.M., 1992, The amphipathic helix in the exchangeable apolipoproteins: a review of secondary structure and function, J Lipid Res, 33, 141-66.

Segrest, J.P., Jones, M.K., Klon, A.E., Sheldahl, C.J., Hellinger, M., De Loof, H., Harvey, S.C., 1999, A detailed molecular belt model for apolipoprotein A-I in discoidal high density lipoprotein, J Biol Chem, 274, 31755-8. 
Sembrook, Russell. 2001. Molecular Cloning and Laboratory Manual: Ed. CSHL (Cold Sprimg Harbor Laboratory Press, New York).

Silva, R.A., Hilliard, G.M., Fang, J., Macha, S., Davidson, W.S., 2005a, A threedimensional molecular model of lipid-free apolipoprotein A-I determined by cross-linking/mass spectrometry and sequence threading, Biochemistry, 44, 2759-69.

Silva, R.A., Hilliard, G.M., Li, L., Segrest, J.P., Davidson, W.S., 2005b, A mass spectrometric determination of the conformation of dimeric apolipoprotein A-I in discoidal high density lipoproteins, Biochemistry, 44, 8600-7.

Singer, S.J., Nicolson, G.L., 1972, The fluid mosaic model of the structure of cell membranes, Science, 175, 720-31.

Small, D., 1988, George Lyman Duff memorial lecture. Progression and regression of atherosclerotic lesions. Insights from lipid physical biochemistry., Arteriosclerosis., 8, 103-29.

Stampfer, M.J., Sacks, F.M., Salvini, S., Willett, W.C., Hennekens, C.H., 1991, A prospective study of cholesterol, apolipoproteins, and the risk of myocardial infarction, N Engl J Med, 325, 373-81.

Swaney, J.B., Chang, B.C., 1980, Thermal dependence of apolipoprotein A-Iphospholipid recombination, Biochemistry, 19, 5637-44.

Toledo, J.D., Prieto, E.D., Gonzalez, M.C., Soulages, J.L., Garda, H.A., 2004, Functional independence of a peptide with the sequence of human apolipoprotein A-I central region, Arch Biochem Biophys, 428, 188-97.

Toledo, J.D., Tricerri, M.A., Corsico, B., Garda, H.A., 2000, Cholesterol flux between lipid vesicles and apolipoprotein AI discs of variable size and composition, Arch Biochem Biophys, 380, 63-70.

Toumadje, A., Alcorn, S.W., Johnson, W.C., Jr., 1992, Extending CD spectra of proteins to $168 \mathrm{~nm}$ improves the analysis for secondary structures, Anal Biochem, 200, 321-31.

Tricerri, A., Corsico, B., Toledo, J.D., Garda, H.A., Brenner, R.R., 1998, Conformation of apolipoprotein $\mathrm{AI}$ in reconstituted lipoprotein particles and particle-membrane interaction: effect of cholesterol, Biochim Biophys Acta, 1391, 67-78.

Tricerri, M.A., Behling Agree, A.K., Sanchez, S.A., Bronski, J., Jonas, A., 2001, Arrangement of apolipoprotein A-I in reconstituted high-density lipoprotein 
disks: an alternative model based on fluorescence resonance energy transfer experiments, Biochemistry, 40, 5065-74.

Tricerri, M.A., Behling Agree, A.K., Sanchez, S.A., Jonas, A., 2000, Characterization of apolipoprotein A-I structure using a cysteine-specific fluorescence probe, Biochemistry, 39, 14682-91.

Tricerri, M.A., Sanchez, S.A., Arnulphi, C., Durbin, D.M., Gratton, E., Jonas, A., 2002, Interaction of apolipoprotein A-I in three different conformations with palmitoyl oleoyl phosphatidylcholine vesicles, J Lipid Res, 43, 187-97.

Tricerri, M.A., Toledo, J.D., Sanchez, S.A., Hazlett, T.L., Gratton, E., Jonas, A., Garda, H.A., 2005, Visualization and analysis of apolipoprotein A-I interaction with binary phospholipid bilayers, J Lipid Res, 46, 669-78.

von Eckardstein, A., Huang, Y., Wu, S., Funke, H., Noseda, G., Assmann, G., 1995, Reverse cholesterol transport in plasma of patients with different forms of familial HDL deficiency, Arterioscler Thromb Vasc Biol, 15, 691-703.

Wang, N., Silver, D.L., Thiele, C., Tall, A.R., 2001, ATP-binding cassette transporter A1 (ABCA1) functions as a cholesterol efflux regulatory protein, J Biol Chem, $276,23742-7$.

Weber, G., 1960, Fluorescence-polarization spectrum and electronic-energy transfer in tyrosine, tryptophan and related compounds, Biochem J, 75, 335-45.

Williams, K.J., Tabas, I., 1995, The response-to-retention hypothesis of early atherogenesis, Arterioscler Thromb Vasc Biol, 15, 551-61.

Wilson, C., Wardell, M.R., Weisgraber, K.H., Mahley, R.W., Agard, D.A., 1991, Threedimensional structure of the LDL receptor-binding domain of human apolipoprotein E, Science, 252, 1817-22.

Yadava, A., Ockenhouse, C.F., 2003, Effect of codon optimization on expression levels of a functionally folded malaria vaccine candidate in prokaryotic and eukaryotic expression systems, Infect Immun, 71, 4961-9.

Yokoyama, S., 2006, Assembly of high-density lipoprotein, Arterioscler Thromb Vasc Biol, 26, 20-7.

Yokoyama, S., Fukushima, D., Kupferberg, J.P., Kezdy, F.J., Kaiser, E.T., 1980, The mechanism of activation of lecithin:cholesterol acyltransferase by apolipoprotein A-I and an amphiphilic peptide, J Biol Chem, 255, 7333-9. 